\title{
HYDROGEOLOGIC CHARACTERIZATION OF THE U-3bI COLLAPSE ZONE
}

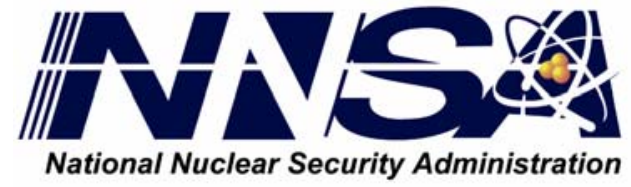

This work was done by Bechtel Nevada and National Security Technologies, LLC, under Contract Numbers DE-AC08-96NV11718 and DE-AC52-06NA25946, respectively, with the U.S. Department of Energy. 


\section{DISCLAIMER STATEMENT}

Reference herein to any specific commercial product, process, or service by trade name, trademark, manufacturer, or otherwise, does not necessarily constitute or imply its endorsement, recommendation, or favoring by the U.S. Government or any agency thereof or its contractors or subcontractors.

\section{AVAILABILITY STATEMENT}

Available for sale to the public from-

U.S. Department of Commerce

National Technical Information Service

5285 Port Royal Road

Springfield, VA 22161-0002

Telephone: 800.553 .6847

Fax: 703.605.6900

E-mail: orders@ntis.gov

Online ordering: http://www.ntis.gov/ordering.htm

Available electronically at http://www.osti.gov/bridge.

Available for a processing fee to U.S. Department of Energy and its contractors, in paper, from-

U.S. Department of Energy

Office of Scientific and Technical Information

P.O. Box 62

Oak Ridge, TN 37831-0062

Telephone: 865.576.8401

Fax: 865.576.5728

E-mail: reports@adonis.osti.gov 
DOE/NV/11718--1271

DOE/NV/25946--042

\title{
Hydrogeologic Characterization of the U-3bl Collapse Zone
}

\author{
Prepared by \\ Bechtel Nevada and National Security Technologies, LLC \\ Geotechnical Sciences \\ Las Vegas, Nevada
}

September 2006

This work was done by Bechtel Nevada and National Security Technologies, LLC under Contract Numbers DE-AC08-96NV11718 and DE-AC52-06NA25946, respectively, with the U.S. Department of Energy. 
This page intentionally left blank. 


\section{ABSTRACT}

The U-3bl collapse crater was formed by an underground nuclear test in August 1962. This crater and the adjoining U-3ax crater were subsequently developed and used as a bulk low-level radioactive waste disposal cell $(\mathrm{U}-3 \mathrm{ax} / \mathrm{bl})$, which is part of the Area 3 Radioactive Waste Management Site at the Nevada Test Site (NTS). Various investigations have been conducted to assess the hydrogeologic characteristics and properties in the vicinity of the U-3ax/bl waste disposal cell. This report presents data from one of these investigations, conducted in 1996. Also included in this report is a review of pertinent nuclear testing records, which shows that the testing operations and hydrogeologic setting of the U-3ax/bl site were typical for the period and location of testing.

Borehole U-3bl-D2 is a 45-degree-angle hole drilled from the edge of the crater under the waste cell to intercept the U-3bl collapse zone, the disturbed alluvium between the crater (surface collapse sink) and the nuclear test cavity. A casing-advance system with an air percussion hammer was used to drill the borehole, and air was used as the drilling fluid. Properties of the U-3bl crater collapse zone were determined from cores collected within the interval, 42.1 to 96.6 meters (138 to 317 feet) below the ground surface. Selected core samples were analyzed for particle density, particle size, bulk density, water retention, hydraulic conductivity, water content, water potential, chloride, carbonate, stable isotopes, and tritium.

Physical and hydraulic properties were typical of alluvial valley sediments at the NTS. No visual evidence of preferential pathways for water transport was observed in the core samples. Soil parameters showed no trends with depth. Volumetric water content values ranged from 0.08 to 0.20 cubic meters per cubic meter, and tended to increase with depth. Water-retention relations were typical for soils of similar texture. Water potentials ranged from -1.9 MegaPascals at a depth of 42.10 meters (138 feet) to -0.4 MegaPascals at 94.58 meters (310 feet), generally increasing with depth. Relationships between hydraulic conductivity and water content were typical of sandy soil, with hydraulic conductivity decreasing rapidly as the soil dried. Variability of hydraulic conductivity reflected layering and showed no trend with depth.

Stable isotope compositions were typical of water that had infiltrated during cooler past climate conditions. Uniformity of concentrations versus depth indicated that evaporation was not occurring at the sampled interval. Tritium concentrations in pore water ranged from $2.68 \times 10^{3}$ to $1.22 \times 10^{4}$ picoCuries per liter, which are greater than expected from atmospheric deposition of tritium, but not at a level to raise environmental concerns. The tritium is most likely a product of nuclear testing. 
This page intentionally left blank. 


\section{PREFACE}

This report is a reissue of a limited-distribution Bechtel Nevada $(\mathrm{BN})$ data report approved for formal publication. National Security Technologies, LLC (NSTec) prepared this revision for publication in order to provide broader access to the data and to facilitate closure planning for the Area 3 Radioactive Waste Management Site (RWMS) at the Nevada Test Site (NTS). Although the report has been revised slightly to conform to current editorial standards of NSTec and the U.S. Department of Energy (DOE), National Nuclear Security Administration Nevada Site Office (NNSA/NSO), the data and interpretations contained within have not changed. The abstract, preface, list of acronyms and abbreviations, and introductory paragraphs have been added for clarity and improved user friendliness.

With the exception of the location maps (Figures 1 and 2), most of the graphics have not been updated. Many of the engineering drawings, figures, and tables in Attachment A are reproductions of records from 1962. In some cases, the original record was in poor condition or only a poor quality reproduction of the original was available. Similarly, some of the summary figures and tables from the 1998 report in Attachments C and D are reproductions from paper copies because electronic files were inaccessible. The best available copy of each item was used to produce this report. The history of the document and its relationship to other investigations and DOE publications follows.

Characterization of the U-3bl collapse zone was one of a series of investigations conducted by the Special Projects Section of Reynolds Electrical \& Engineering Company, Inc. (REECo) and $\mathrm{BN}$ in the 1990s to characterize the upper vadose zone hydrogeology of the Area 3 RWMS at the NTS for the DOE Nevada Operations Office. REECo and BN documented the results in several limited-distribution data reports that were not formally approved by DOE for public release. To facilitate broader access to this data, BN began submitting these older REECo and BN reports through the DOE's Scientific and Technical Information Product review process for formal publication. NSTec succeeded BN in July 2006, and is continuing this publication effort for the NNSA/NSO, the successor to the DOE Nevada Operations Office.

BN transmitted the Hydrogeologic Characterization of the U-3bl Collapse Zone report as a communication to the DOE Nevada Operations Office in November 1996. The report was later reissued as one of several data report attachments to the BN February 1998 limited-distribution report, Hydrogeologic Characterization of the Unsaturated Zone at the Area 3 Radioactive Waste Management Site, DOE/NV/11718--210. Although the nested reports received document numbers, they were not formally released by DOE for publication. The attached reports included: 
- Hydrogeologic Characterization of U-3at Collapse Zone: Data Report (DOE/NV/11718--199)

- Hydrogeologic Characterization of U-3bh Collapse Zone: Data Report (DOE/NV/11718--198)

- Hydrogeologic Characterization of U-3bl Collapse Zone: Data Report (DOE/NV/11718--197)

To reduce confusion and citation errors, these three 1998 data reports are being published as separate documents. BN revised the U-3at data report, which was published as DOE/NV/11718--199 REV 1 in 2005, and NSTec expects to publish the U-3bh report concurrently with this U-3bl report in 2006.

Data in this report supplement the U-3bl characterization data presented in the BN August 2005 report, Site Characterization Data from the U3ax/bl Exploratory Boreholes at the Nevada Test Site, DOE/NV/11718--003-REV.1.

Summary data from these studies are also included in the Performance Assessment/Composite Analysis for the Area 3 Radioactive Waste Management Site, Nye County, Nevada, Revision 2.1, DOE/NV--491-REV 2.1, prepared by G. J. Shott, Y. Yucel, M. J. Sully, L. E. Barker, S. E. Rawlinson, and B. A. Moore, and published in October 2000. 


\section{Table of Contents}

\begin{tabular}{|l|l}
\hline Abstract \\
\hline \hline Preface..$\ldots \ldots \ldots \ldots$ \\
\hline List of Figures
\end{tabular}

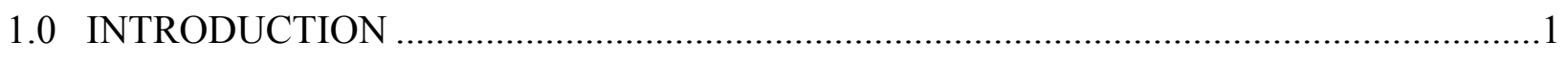

1.1 Site Description and History ...............................................................................

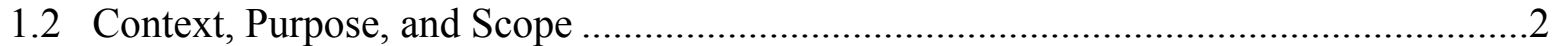

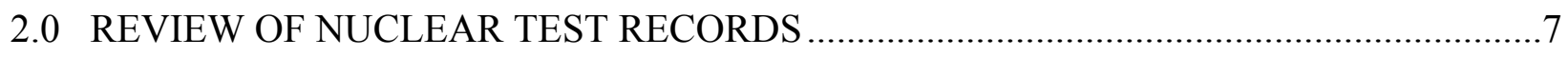

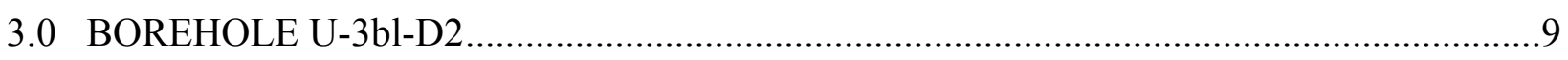

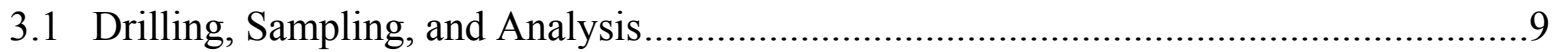

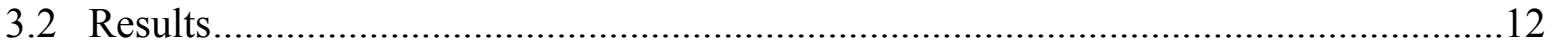

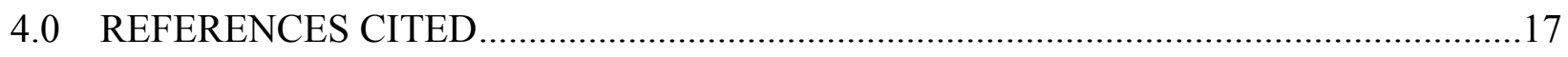

ATTACHMENT A- Data Report and Review: U3ax/bl Characterization and Closure

ATTACHMENT B. Borehole Log Sheets for U-3bl-D2

ATTACHMENT C Characterization Data Figures for Borehole U-3bl-D2

ATTACHMENT D- Characterization Data Tables for Borehole U-3bl-D2

DISTRIBUTION LIST 


\section{List of Figures}

Number

Title

Page

1 Location of Area 3 Radioactive Waste Management Site

2 Area 3 Radioactive Waste Management Site Showing Locations of Characterization Boreholes .5

3 Schematic Showing the Location of Borehole U-3bl-D2 with Respect to the U-3bl Crater, Hypothesized Margins of the Collapse Zone, and Estimated Test Cavity .11

C-1 Particle Density versus Depth for U-3bl-D2 ..............................................................

C-2 Sand, Silt, and Clay Fractions versus Depth for U-3b1-D2 …………………..................2

C-3 Dry Bulk Density versus Depth for U-3bl-D2 ..........................................................

C-4 Water Retention Relations for U-3bl-D2 Samples at 10 Depths from 42.3 to

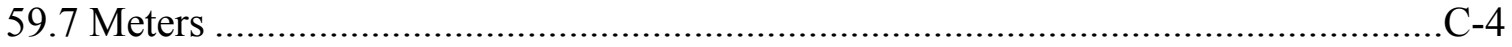

C-5 Water Retention Relations for U-3bl-D2 Samples at 10 Depths from 61.7 to 79.1 Meters

C-6 Water Retention Relations for U-3bl-D2 Samples at 9 Depths from 81.1 to 96.5 Meters

C-7 Hydraulic Conductivity versus Volumetric Water Content for U-3bl-D2 Samples at 10 Depths from 42.3 to 59.7 Meters

C-8 Hydraulic Conductivity versus Volumetric Water Content for U-3bl-D2 Samples at 10 Depths from 61.7 to 79.1 Meters

C-9 Hydraulic Conductivity versus Volumetric Water Content for U-3bl-D2 Samples at 9 Depths from 81.1 to 96.5 Meters .............................................................................

C-10 Volumetric Water Content versus Depth for U-3bl-D2 .............................................

C-11 Water Potential versus Depth for U-3bl-D2 …….....................................................11

C-12 Stable Hydrogen Isotope Concentration in Pore Water from U-3bl-D2 versus Depth..C-12

C-13 Stable Oxygen Isotope Concentration in Pore Water from U-3bl-D2 versus Depth.....C-13

C-14 Stable Isotope Concentration in Pore Water from U-3bl-D2 Alluvium Samples with respect to Local Meteoric Water Line ...........................................................................

C-15 Soil Chloride Concentration versus Depth for U-3bl-D2 ……………………..............15

C-16 Calcium Carbonate Equivalent within the Fine-Earth Fraction (less than 2 millimeters)

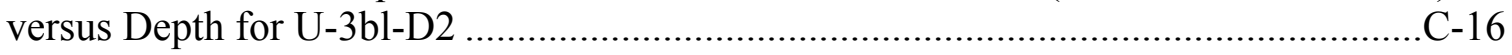

C-17 Tritium Concentration versus Depth for U-3bl-D2 ……............................................17 


\section{List of Tables}

Number

1 Location and Depth of Characterization Borehole U-3bl-D2 …........................................

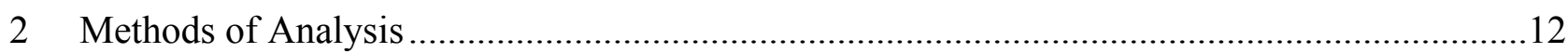


This page intentionally left blank. 


\section{List of Acronyms and Abbreviations}

\begin{tabular}{|c|c|}
\hline $\begin{array}{l}\text { ASTM } \\
\text { bgs }\end{array}$ & $\begin{array}{l}\text { American Society for Testing and Materials } \\
\text { below ground surface }\end{array}$ \\
\hline $\mathrm{BN}$ & Bechtel Nevada \\
\hline CA & Composite Assessment \\
\hline CAU & casing-advance under-reaming \\
\hline $\mathrm{cm}$ & centimeter(s) \\
\hline$\delta$ & delta \\
\hline $\mathrm{D}$ & deuterium \\
\hline$\delta \mathrm{D}$ & $\begin{array}{l}\text { parts per thousand enrichment or depletion of deuterium : protium relative to the } \\
\text { proportion in SMOW }\end{array}$ \\
\hline$\delta^{18} \mathrm{O}$ & $\begin{array}{l}\text { parts per thousand enrichment or depletion of }{ }^{18} \mathrm{O}:{ }^{16} \mathrm{O} \text { relative to the proportion in } \\
\text { SMOW }\end{array}$ \\
\hline DOE & U.S. Department of Energy \\
\hline $\mathrm{ft}$ & foot (feet) \\
\hline $\mathrm{ft}^{3}$ & cubic feet \\
\hline in. & inch(es) \\
\hline $\mathrm{kg} / \mathrm{m}^{3}$ & kilogram(s) per cubic meter \\
\hline LMWL & Local Meteoric Water Line \\
\hline $\mathrm{m}$ & meter(s) \\
\hline $\mathrm{m}^{3}$ & cubic meter(s) \\
\hline $\mathrm{mg} / \mathrm{kg}$ & milligram(s) per kilogram \\
\hline $\mathrm{mm}$ & millimeter(s) \\
\hline $\mathrm{MPa}$ & MegaPascal(s) \\
\hline $\mathrm{m} / \mathrm{s}$ & meters per second \\
\hline NESTT & Northwest Environmental Services, Testing, and Training \\
\hline NNSA/NSO & $\begin{array}{l}\text { U.S. Department of Energy, National Nuclear Security Administration Nevada Site } \\
\text { Office }\end{array}$ \\
\hline NSTec & National Security Technologies, LLC \\
\hline NTS & Nevada Test Site \\
\hline${ }^{16} \mathrm{O}$ & oxygen-16 \\
\hline${ }^{18} \mathrm{O}$ & oxygen-18 \\
\hline OD & outside diameter \\
\hline $\begin{array}{l}\mathrm{PA} \\
0 / 00\end{array}$ & $\begin{array}{l}\text { Performance Assessment } \\
\text { parts per thousand }\end{array}$ \\
\hline RWMS & Radioactive Waste Management Site \\
\hline SMOW & Standard Mean Ocean Water \\
\hline
\end{tabular}


This page intentionally left blank. 


\subsection{INTRODUCTION}

The work described in this document was conducted in the 1990s by personnel of Reynolds Electrical and Engineering Company, Inc., and Bechtel Nevada (BN) at the Nevada Test Site (NTS). This study was one of several hydrogeologic characterization studies of the upper vadose zone at the Area 3 Radioactive Waste Management Site (RWMS) conducted for the U.S. Department of Energy (DOE), National Nuclear Security Administration Nevada Site Office (NNSA/NSO; formerly U.S. Department of Energy, Nevada Operations Office), Waste Management Project.

This document is an update of the February 1998 data report prepared by BN, which was presented as an attachment in a limited-distribution report, Hydrogeologic Characterization of the Unsaturated Zone at the Area 3 Radioactive Waste Management Site (DOE/NV/11718--210). BN first submitted the limited-distribution report as a separate communication to DOE in November 1996.

Although the report has been revised slightly for clarity and to conform to current editorial standards of National Security Technologies, LLC (successor to BN), and NNSA/NSO, the data and interpretations have not changed. No new data have been added to this report, although relevant studies of the Area 3 RWMS have been conducted in the intervening years.

\subsection{Site Description and History}

The Area 3 RWMS is located in Yucca Flat at the NTS in Nye County, Nevada (Figure 1). The topography of the region is distinguished by north-south trending mountain ranges separated by alluvial valleys. The geology of Yucca Flat in the vicinity of the RWMS is characterized by thick sections of Paleozoic sedimentary rocks overlain by Tertiary volcanic rocks and deposits of alluvium consisting of post-volcanic sands and gravels (DOE, 1996a). At the Area 3 RWMS, the alluvium is more than 305 meters $(\mathrm{m})(1,000$ feet [ft] $)$ thick, and the depth to groundwater is approximately $488 \mathrm{~m}(1,600 \mathrm{ft})$. Precipitation at this site averages 159 millimeters per year (6.3 inches per year) and average monthly temperatures range from $2^{\circ}$ Celsius ( $36^{\circ}$ Fahrenheit) in January to $25^{\circ}$ Celsius ( $77^{\circ}$ Fahrenheit) in July (Special Operations and Research Division Web site).

Figure 2 shows the location of U-3bl, one of seven subsidence craters within the boundaries of the Area 3 RWMS. These craters were formed by underground nuclear tests in the early 1960s, which were conducted hundreds of meters below the ground surface in shafts bored vertically 
into the alluvium. Upon detonation of the nuclear device, the extreme pressure and temperature generated formed a cavity in the alluvium. When the gas pressure dissipated to a point at which it could no longer support the overburden, the roof of the cavity collapsed and the void region propagated upward to the surface, forming a saucer-like subsidence crater (U.S. Congress, 1989). The region through which the void propagated is referred to as the "collapse zone" or "chimney." At the time of their formation, the seven craters within the Area 3 RWMS ranged from 121.9 to $176.8 \mathrm{~m}$ (400 to $580 \mathrm{ft}$ ) in diameter, and from 14.0 to $32.0 \mathrm{~m}$ (46 to $105 \mathrm{ft}$ ) in depth (Plannerer, 1996).

Five of the craters (U-3ah, U-at, U-3ax, U-3bh, and U-3bl) have been used for disposal of lowlevel bulk radioactive waste. A waste cell called U-3ax/bl was formed from the U-3ax and U-3bl subsidence craters by excavating soil between the two craters (as shown in Figure 2) to form a single cell with a capacity of approximately 227,815 cubic meters $\left(\mathrm{m}^{3}\right)(8,050,000$ cubic feet $\left.\left[\mathrm{ft}^{3}\right]\right)$. Prior to excavation, U-3ax was $18.9 \mathrm{~m}(62 \mathrm{ft})$ deep and $138.1 \mathrm{~m}(453 \mathrm{ft})$ in diameter, and U-3bl was $14.0 \mathrm{~m}$ (46 ft) deep and $121.9 \mathrm{~m}$ (400 ft) in diameter. Disposal in U-3ax, the deeper crater, began in the late 1960s. Disposal in U-3bl began in 1984, when the level in U-3ax reached the bottom elevation of U-3bl. Waste forms consisted primarily of contaminated soil and scrap metal, with some construction debris, equipment, and containerized waste. The only liquid waste placed in U-3ax or U-3bl consisted of a small quantity of petroleum products remaining in machinery and tanks. The radioactive constituents were estimated to be approximately 1,200 curies, with 85 percent of the activity being due to tritium. The next largest single contributor was cobalt-60, which accounted for 1.6 percent of the total curie content. Most of the radioactive constituents were disposed during the years 1976 to 1981 . The only known hazardous constituents were lead and cadmium. Disposal practices and waste inventory for U3-ax/bl have been documented by Elletson and Johnejack (1995).

A temporary cover of native alluvium was placed over the waste in December 1987 . The cover

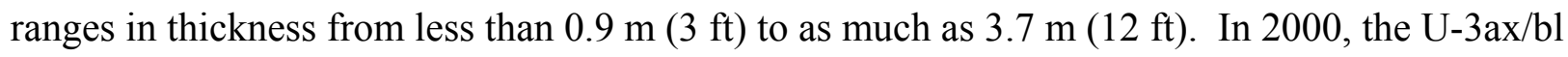
waste disposal unit was closed under Interim Resource Conservation and Recovery Act status, as described in the closure plan (DOE, 2000a) and the closure report (DOE, 2001).

\subsection{Context, Purpose, and Scope}

Section 2.0 of this data report summarizes information regarding the 1962 nuclear test codenamed BOBAC, that led to the formation of crater U-3bl. Section 3.0 describes the sampling methods and results from characterization borehole U-3bl-D2 (drilled in 1996), including field 


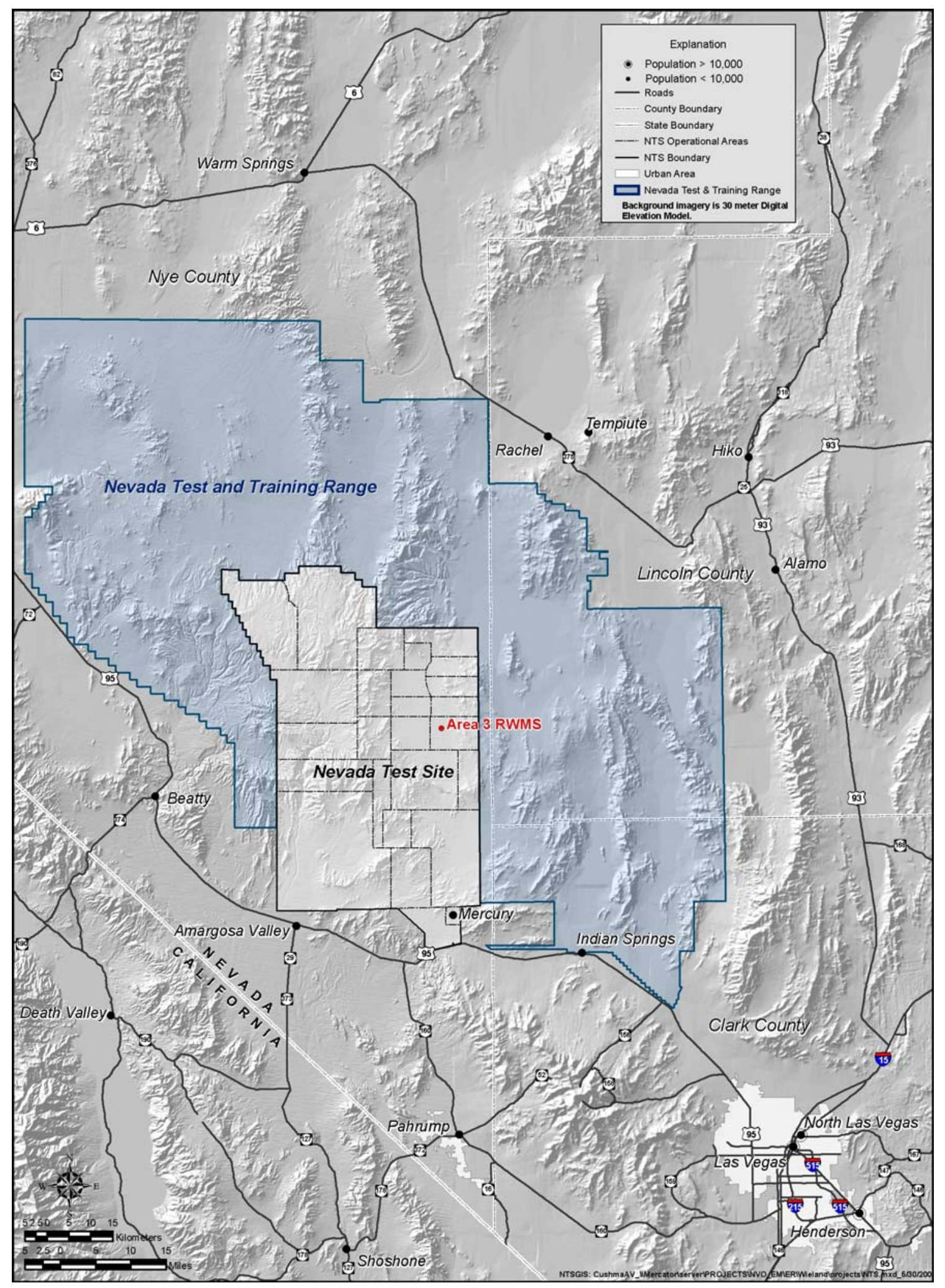

Figure 1

Location of Area 3 Radioactive Waste Management Site 
This page intentionally left blank. 


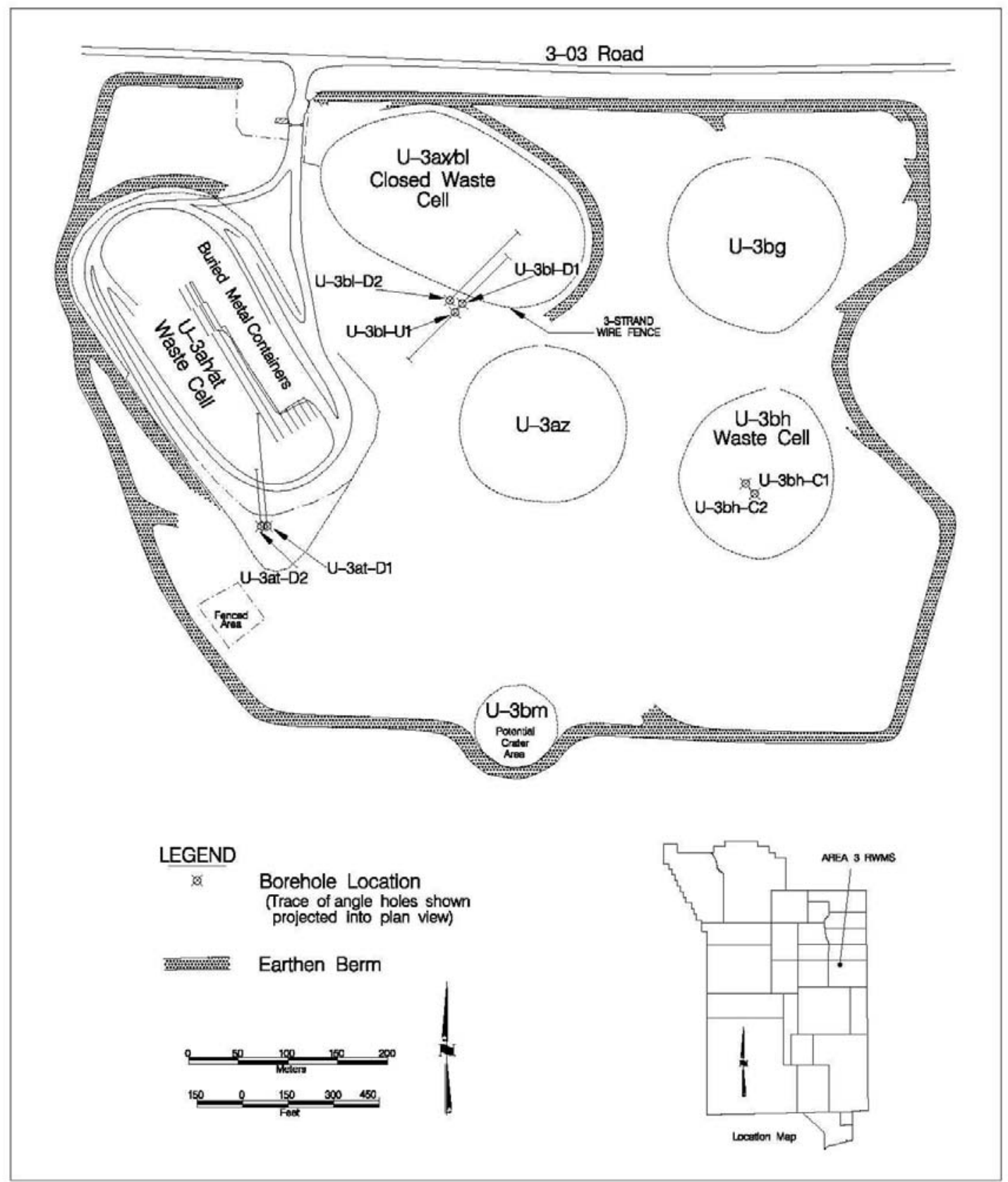

Figure 2

Area 3 Radioactive Waste Management Site Showing Locations of Characterization Boreholes 
descriptions and laboratory analyses of 29 cores. The main objective of the review of the nuclear test records was to find site-specific characterization information that could be used to develop a conceptual model of the vadose zone for closure planning for the U-3ax/bl waste disposal unit. A sub-objective was to attempt to identify any potential preferential transport pathways related to the nuclear test that may affect closure.

The U-3bl collapse zone investigation was part of a broader characterization study of the upper alluvium of the Area 3 RWMS, conducted primarily to provide data for the Performance Assessment (PA) and Composite Analysis (CA) of the Area 3 RWMS. A PA is required by DOE Order 435.1, Radioactive Waste Management (DOE, 1999), for radioactive wastes disposed of on or after September 26, 1988 (DOE Order 435.1 superseded DOE Order 5820.2A ([1988]). The requirement for a CA for disposal sites is established in Guidance for Composite Analysis of the Impact of Interacting Source Terms of the Radiological Protection of the Public from Department of Energy Low-Level Waste Disposal Facilities (DOE, 1996b). Both analyses require site characterization information to formulate a conceptual model of the transport processes occurring in the system and to provide estimates of the variables used to quantify these processes.

In the 1990s, a total of seven characterization borings were drilled at or near the three waste cells (Figure 2). Three data reports (BN, 1998; 2005a; 2005b) provide detailed information on six of the characterization boreholes, and the seventh is reported here. Three of the seven characterization boreholes were drilled in the vicinity of $U-3 b l$ to determine the physical and hydrological properties of the disturbed alluvium in the collapse zones below the craters. Two angle borings were drilled in 1994, one below the U3ax/bl waste disposal cell and one away from the U3bl crater in relatively undisturbed alluvium (BN, 2005a). In 1996, a second angle borehole, designated U-3bl-D2 (the subject of this data report) was drilled below the U-3ax/b1 waste disposal cell to intercept the U-3bl collapse zone; that is, the disturbed alluvium between the crater (surface collapse sink) and the nuclear test chamber.

The physical and hydraulic property data from these studies were used to develop the conceptual hydrogeologic model for the Area 3 RWMS and for flow and transport simulations. The report on the Area 3 RWMS PA and CA (Shott et al., 2000) summarizes and interprets the complete characterization study data set from all seven borings. 


\subsection{REVIEW OF NUCLEAR TEST RECORDS}

A review of available data pertinent to the BOBAC underground nuclear test was completed by W. L. Hawkins of Los Alamos National Laboratory (Hawkins, 1994). The Nevada Test Site Drilling and Mining Summary (Raytheon Services Nevada, 1991) was also consulted. Principal findings are summarized here, and the detailed review by Hawkins, including construction information for all boreholes associated with the BOBAC test, is reproduced in Attachment A.

Hawkins noted that the operations and hydrogeologic setting for the BOBAC test conducted in the U3bl emplacement hole were typical for the period and location of testing. Construction of the emplacement hole began on June 2, 1962, with the drilling of a small-diameter pilot hole. The pilot hole was opened to a diameter of $1.2 \mathrm{~m}(4 \mathrm{ft})$ to a depth of $210.3 \mathrm{~m}(690 \mathrm{ft})$ below ground surface (bgs), and cased to a depth of $208.8 \mathrm{~m}(685 \mathrm{ft})$ bgs.

Six additional boreholes were drilled at the BOBAC site: four instrument holes drilled prior to the test, and two "post-shot" holes. Three of the instrument holes were drilled to a depth of $219.5 \mathrm{~m}(720 \mathrm{ft})$ bgs, and cased from the surface to a depth of $146.3 \mathrm{~m}(480 \mathrm{ft}) \mathrm{bgs}$. The fourth instrument hole was drilled to a depth of $234.7 \mathrm{~m}(770 \mathrm{ft}) \mathrm{bgs}$, and also cased to a depth of $146.3 \mathrm{~m}$ (480 ft) bgs. Following the installation of instrumentation, these boreholes were

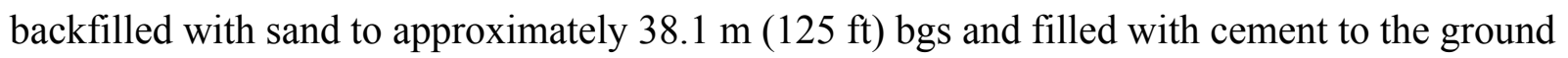
surface. Following the test, two post-shot holes were drilled to depths of 234.1 and $237.1 \mathrm{~m}$ (768 and $773 \mathrm{ft}$ ) bgs, but were cased only to $11.6 \mathrm{~m}$ (38 ft) bgs. The post-shot boreholes were probably left unplugged with a welded cap, blind flange, or abandonment valve at the top of the surface casing. There are no records describing how the post-shot holes were abandoned; however, with decades of subsequent ground motion, it is most likely that these holes have collapsed below the casing.

The device was placed at a depth of $195.1 \mathrm{~m}$ (640 ft) bgs in the emplacement hole, and the hole was stemmed to the surface. The first interval of stemming material consisted of $16 \mathrm{~m}^{3}\left(565 \mathrm{ft}^{3}\right)$ of magnetite sand placed at the bottom for instrument shielding. The magnetite layer was followed by alternating layers of coarse and fine sand, with the layers of fine sand $(1.8 \mathrm{~m} \mathrm{[6 \textrm {ft } ]}$ thick) placed every $30.5 \mathrm{~m}$ (100 ft). A gypsum cement plug was poured as a gas seal to complete the final $3.0 \mathrm{~m}(10 \mathrm{ft})$ of stemming.

The BOBAC device was detonated on August 24, 1962 (DOE, 2000b). Collapse of the cavity occurred 8.2 minutes later, forming a rubble chimney and a surface subsidence crater. No 
additional subsidence has been reported. The crater had a radius of $61.0 \mathrm{~m}(200 \mathrm{ft})$ and an estimated volume of $140,594 \mathrm{~m}^{3}\left(4,968,000 \mathrm{ft}^{3}\right)$. There was no evidence of any release of radioactivity resulting from the test. 


\subsection{BOREHOLE U-3bl-D2}

Borehole U-3-bl-2 was the third hole drilled at or near the U-3bl crater for characterization of the near-surface alluvium. See BN, 2005a, for information about the first two holes, UE-3bl-D1 and UE-3bl-U1.

\subsection{Drilling, Sampling, and Analysis}

Drilling of borehole U-3bl-D2 began on February 29, 1996, adjacent to the U-3bl crater produced by the BOBAC nuclear test. The borehole was drilled at an angle of approximately 45 degrees so that it would pass under the waste cell and into the collapse zone below the crater. The location of borehole U-3bl-D2 is shown in Figure 2, and coordinates, land surface elevation, and depth are provided in Table 1.

Table 1

Location and Depth of Characterization Borehole U-3bl-D2

\begin{tabular}{||c|c|c|c|c||}
\hline \multirow{3}{*}{ Borehole } & \multirow{2}{*}{$\begin{array}{c}\text { Total Vertical } \\
\text { Depth } \\
\text { meters (feet) }\end{array}$} & $\begin{array}{c}\text { Land Surface Elevation } \\
\text { Above Sea Level } \\
\text { meters (feet) }\end{array}$ & \multicolumn{2}{|c||}{$\begin{array}{c}\text { Nevada State Central Zone } \\
\text { Coordinates (NAD 27) }\end{array}$} \\
\cline { 4 - 5 } & & & $\begin{array}{c}\text { North } \\
\text { meters (feet) }\end{array}$ & $\begin{array}{c}\text { East } \\
\text { meters (feet) }\end{array}$ \\
\hline \hline U-3bl-D2 & $96.6(317)$ & $1,223(4,014)$ & $\begin{array}{c}254,871.21 \\
(836,189.97)\end{array}$ & $\begin{array}{c}209,528.20 \\
(687,427.09)\end{array}$ \\
\hline
\end{tabular}

NAD 27= North American Datum of 1927.

Surface casing was set at a 45-degree angle in a trench $2.1 \mathrm{~m}(7 \mathrm{ft})$ deep, located near the edge of the temporary cover over U-3bl. The surface casing served to reduce dust and help guide the drill casing. The borehole was drilled with an Ingersoll-Rand T-4 drill rig using a casingadvance under-reaming (CAU) system. The CAU system consisted of an air percussion hammer attached to a drill rod within a casing 16.8 centimeter $(\mathrm{cm})(6.63 \mathrm{inch}$ [in.]) in diameter. A drive shoe was attached to the bottom of the casing. The air-percussion hammer drilled a hole slightly larger than the casing and advanced the casing by impacting the shoe. As the casing was advanced, additional casing segments were added at the surface until a coring depth was reached. Drill cuttings were forced to the surface through the casing, using only air as the drilling fluid. 
The major advantage of a CAU system is that the continuous placement of casing in the borehole during drilling prevents the borehole from collapsing. Therefore, CAU systems are well suited for use in unconsolidated alluvium, where borehole collapse is a constant risk.

Core samples were obtained at approximately $3.05-\mathrm{m}(10-\mathrm{ft})$ intervals, in a $0.76-\mathrm{m}-(2.5-\mathrm{ft}-)$ long solid-tube core barrel with an outside diameter (OD) of $11.43 \mathrm{~cm}$ (4.5 in.). The core barrel was lined with ten clear polycarbonate liner segments $7.62 \mathrm{~cm}$ (3 in.) long with an OD of $8.89 \mathrm{~cm}$ (3.5 in.). The core barrel was driven into the bottom of the hole using the air percussion hammer. After the core barrel was retrieved, the liner segments were removed using a pneumatic core extruder. A geologist developed a geologic description of the core by examining the open ends of each liner segment. Geologic descriptions consisted of visual estimates of moisture content, particle size distribution, lithology, sorting, and grain shape; any anomalies were also noted. The liner segments were then capped, taped, labeled with sample identification numbers, and sealed in tubular plastic laminate for shipping to laboratories for analyses. Sampling in U-3bl-D2 began at a borehole length of $61.3 \mathrm{~m}(201 \mathrm{ft})$, which corresponds to a vertical depth of $42.1 \mathrm{~m}(138 \mathrm{ft})$ bgs. The location of the U-3bl-D2 borehole with respect to $\mathrm{U}-3 \mathrm{bl}$ crater and the collapse zone is shown in Figure 3. The shaded area denotes the zone sampled.

At a borehole length of 66.8 (219 ft), the drive shoe detached from the casing, which required the removal of both the drill and surface casings from the borehole for repairs. A new 6.1-m (20-ft) length of 27.31-cm (10.75-in.) casing was then installed at a 45-degree angle to serve as the surface casing. Drilling proceeded to a borehole length of $66.8 \mathrm{~m}(219 \mathrm{ft})$ using 21.9-cm(8.63-in.-) diameter casing. Below this depth, 16.8-cm- (6.63-in.-) diameter casing was used, and drilling and sampling continued to a final borehole length of $145.4 \mathrm{~m}(477 \mathrm{ft})$. This length corresponds to a vertical depth of $95.7 \mathrm{~m}(314 \mathrm{ft})$ bgs. A final core run was made at this depth.

Drillers completed 29 core runs in the U-3bl-D2 borehole. Although core recovery was generally less than 100 percent, recovery was sufficient for all runs to meet the minimum sample requirements of the analytical laboratories. The method of analysis, source of the method, and the laboratory performing the analysis are shown in Table 2 for each of the characterized properties. Volumetric water content and bulk density were measured on two cores from each core run to provide better knowledge of the variation of these properties with depth. BN audited and approved the quality assurance programs for Huffman Laboratories and Northwest Environmental Services, Testing, and Training. 
$U-3$ DI-D2 BOREHOLE

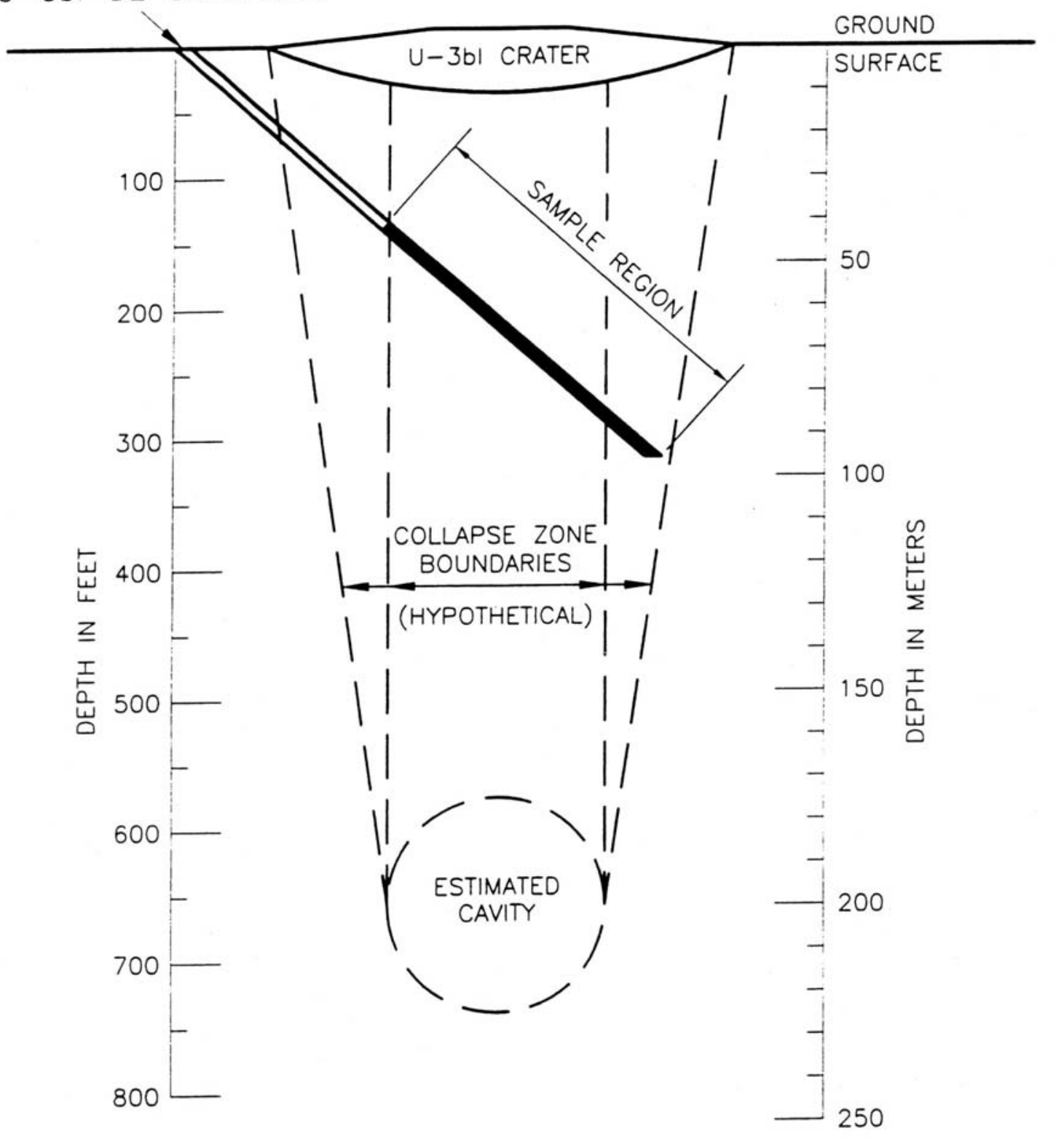

O: $\backslash$ CADO \AREA_3\U3EL_SCH.DWG

Figure 3

Schematic Showing the Location of Borehole U-3bl-D2 with Respect to the U-3bl Crater, Hypothesized Margins of the Collapse Zone, and Estimated Test Cavity 
Table 2

Methods of Analysis

\begin{tabular}{|c|c|c|c|}
\hline Characteristic/Property & Method & Reference & Laboratory \\
\hline Geologic Description & Visual Manual & $\operatorname{ASTM}^{\mathrm{a}}(1990)$ & $\mathrm{BN}^{\mathrm{b}}$ \\
\hline Particle Density & Liquid Pycnometer & Snyder et al. (1996) & $\mathrm{HL}^{\mathrm{C}}$ \\
\hline Particle Size & Sieve and Pipette & Snyder et al. (1996) & $H L$ \\
\hline Bulk Density & Core & Blake and Hartge (1986) & NESTT ${ }^{d} / B N$ \\
\hline Water Retention & Centrifugation & Hoffman (1963) & NESTT \\
\hline $\begin{array}{l}\text { Hydraulic Conductivity } \\
\text { Saturated } \\
\text { Unsaturated }\end{array}$ & $\begin{array}{l}\text { Constant Head } \\
\text { Centrifugation }\end{array}$ & $\begin{array}{l}\text { ASTM (1974) } \\
\text { Conca and Wright (1992) }\end{array}$ & NESTT \\
\hline Water Content & Volumetric & Snyder et al. (1996) & NESTT/BN \\
\hline Water Potential & Water Activity Meter & Snyder et al. (1996) & BN \\
\hline Chloride & Ion Chromatography & Snyder et al. (1996) & $\mathrm{HL}$ \\
\hline Carbonate & Pressure Calcimeter & Snyder et al. (1996) & $\mathrm{HL}$ \\
\hline Stable Isotopes & Mass Spectrometer & Gonfiantini (1981) & DRI ${ }^{e}$ \\
\hline Tritium & Liquid Scintillation & Burg (1994) & DRI \\
\hline
\end{tabular}
a American Society for Testing and Materials
b Bechtel Nevada
c Huffman Laboratories Inc.
d Northwest Environmental Services, Testing and Training
e Desert Research Institute

\subsection{Results}

Geologic descriptions based on visual examination of the cores obtained from the U-3bl-D2 borehole were recorded on borehole log sheets, which are reproduced in Attachment B. No visual evidence of preferential pathways for water was observed in the cores. Data plots depicting characteristics and properties of the characterization samples determined by laboratory analyses are presented in Attachment $C$. These same results are provided in tabular form in Attachment D. All results are presented in terms of the vertical depth of the sample rather than borehole drilled length.

The variation of particle density with depth is shown in Figure C-1. Particle densities range from 2,210 to 2,460 kilograms per cubic meter $\left(\mathrm{kg} / \mathrm{m}^{3}\right)$. Values show no trends with depth and are 
slightly lower than particle densities previously observed for shallower sediments within the RWMS. Percentages of sand, silt, and clay for the fine-earth (less than 2 millimeters [mm]) fraction of the samples are shown in Figure C-2. Results from this borehole are similar to others from the RWMS, with particle size distribution being dominated by the 0.05 - to $2.0-\mathrm{mm}$ sand fraction. In general, the sand fraction ranges from approximately 61 to 95 percent, with an average of 81 percent. The silt and clay fractions are less than 30 and 10 percent, respectively. These fractions are typical of loamy sand to sandy loam soil texture. The sample with the largest combined fraction of silt and clay (39 percent) is at a depth of $63.4 \mathrm{~m}$ (208 ft). Dry bulk density, shown in Figure C-3, ranges from 1,230 to $1,830 \mathrm{~kg} / \mathrm{m}^{3}$, with no obvious trend with depth. These values are within the range of bulk densities commonly observed for undisturbed alluvium on the NTS.

Water retention relations for the characterization samples are shown in Figures C-4 through C-6. This characteristic, while variable, is relatively consistent for the cores tested and is typical of water retention relations for other soils of similar texture. The range of water retention relations is represented by the samples from the depths of 69.5 and $71.3 \mathrm{~m} \mathrm{(228} \mathrm{and} 234 \mathrm{ft})$ bgs. The sample from $69.5 \mathrm{~m}(228 \mathrm{ft})$ had the lowest water content at the initial matric potential of -0.004 MegaPascals (MPa) (16 in. of water) and drained to the lowest water content when a small additional tension was applied. This behavior is typical of coarse-textured materials. This sample has one of the lowest percentages of clay (4.3 percent) and highest percentages of sand (91 percent). The sample from $71.3 \mathrm{~m}(234 \mathrm{ft})$ shows increased water-holding capacity at saturation, because it has one of the highest porosities of the cores sampled. This sample drained less with applied tension because it has the highest clay fraction (16.9 percent) and one of the lowest sand fractions (74 percent).

The relationships between hydraulic conductivity and water content are shown in Figures C-7 through C-9. These hydraulic conductivity-water content relations were measured directly on samples and are not dependent on fitting model parameters to the water retention relations. The results are typical of sandy soil, with hydraulic conductivity decreasing rapidly as the soil dries. While variable, these relations show no trend with depth. The variability of these results reflects the subtle yet distinct differences in hydraulic properties of the alluvium layers. Deviation from

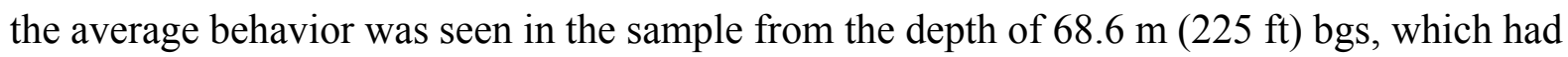
the highest measured hydraulic conductivity over the entire range of water content. At saturation, this sample had a hydraulic conductivity at least two orders of magnitude greater than the majority of other samples. 
The variation of volumetric water content with depth is shown in Figure C-10. Water content values range from 0.08 to 0.20 cubic meters per cubic meter, and tend to increase with depth. The water potential values of samples taken from the U-3bl-D2 borehole range from -1.9 MPa at

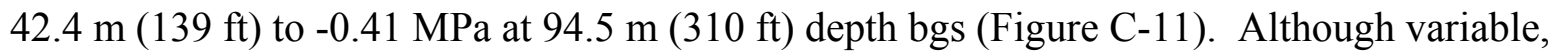
water potential tends to increase with depth. A similar range and trend was reported for water potentials of cores obtained at similar depths in Frenchman Flat (Detty et al., 1993).

Variations in the stable isotopic composition of pore water with respect to meteoric water provide indications of past and current water fluxes in the vadose zone. Stable isotope concentrations are expressed as the difference between the measured ratio of heavier to lighter isotopes in the sample and the same ratio measured in the reference standard (typically standard mean ocean water [SMOW]) in parts per thousand (\%). The most abundant isotopic forms of the element are used. For hydrogen, the ratio measured is deuterium to protium, and for oxygen, oxygen-18 to oxygen-16. In standard delta notation, these ratios normalized to SMOW are referred to as $\delta \mathrm{D}$ and $\delta^{18} \mathrm{O}$, respectively.

Concentrations of the stable isotopes of hydrogen and oxygen in the pore water of samples obtained from the U-3bl-D2 borehole are shown in Figures C-12 and C-13. Concentrations are reported in standard delta notation in reference to SMOW. Reproducibility of the values is $\pm 1 \%$. Uniformity of the isotopic compositions with depth indicates that the alluvium below $39.6 \mathrm{~m}$ (130 ft) depth is not influenced by evaporation occurring at shallower depths.

Stable isotope concentrations in pore water from characterization samples and precipitation are shown in Figure C-14. The local meteoric water line (LMWL) represents the ratio of stable isotopes in precipitation and was described by Tyler et al. (1996) for the NTS as:

$$
\delta \mathrm{D}=6.26 \cdot \delta^{18} \mathrm{O}-15.3
$$

These authors estimated weighted mean concentrations for winter precipitation to be $-12.5 \%$ and $-93 \%$ for $\delta^{18} \mathrm{O}$ and $\delta \mathrm{D}$, respectively. Winter concentrations represent precipitation under cooler temperatures. Comparing the winter mean concentrations for the NTS with concentrations of the profiles shown in Figures C-12 and C-13, shows the isotopic compositions of the pore water samples fall below the LMWL. These samples are more depleted than weighted mean values for 
winter precipitation alone. These results indicate that the pore water found in the samples from the collapse zone below $39.6 \mathrm{~m}$ (130 ft) must have infiltrated under cooler, past climate conditions.

The soil chloride profile shown in Figure C-15 indicates negligible amounts of chloride present except in one sample. Because this single sample (taken from $84.7 \mathrm{~m}$ [247 ft] bgs), was reported to have a chloride concentration two orders of magnitude higher than the other samples, another sub-sample from this interval was extracted and analyzed. The results of the second analysis were within 8 percent of the original estimate, indicating that the observed elevated chloride concentration was not due to analytical error. An inspection of this core sample and adjacent samples using a binocular microscope and in hand sample, found no obvious lithologic, diagenetic, or pedogenic explanation for the differences in chloride concentration.

Calcium carbonate equivalent for the characterization boreholes is shown with depth in Figure C-16. These results show calcium carbonate equivalent concentrations at 42.4, 46.0, and $63.4 \mathrm{~m}(139,151$, and $208 \mathrm{ft}) \mathrm{bgs}$ to be greater than 11 percent, substantially greater than most other samples analyzed. An inspection of these and adjacent samples under a binocular microscope and in hand sample found no significant difference in lithology, but the matrix of the three samples in question was cemented by calcium carbonate and contained fragments of weathered caliche.

Tritium concentrations versus depth for the characterization samples are shown in Figure C-17. Concentrations ranged from $2.68 \times 10^{3}$ to $1.22 \times 10^{4}$ picoCuries per liter. The maximum concentration was found in the sample from $75.0 \mathrm{~m}(246 \mathrm{ft})$ bgs. Although not at a level to raise environmental concerns, these concentrations are two to three orders of magnitude greater than expected from atmospheric deposition of tritium. This tritium most likely originated as a product of the nuclear test. 
This page intentionally left blank. 


\subsection{REFERENCES CITED}

American Society for Testing and Materials, 1974. "Test Method for Permeability of Granular Soils (Constant Head).” D 2434-68. In: 1987 Annual book of ASTM standards. Vol. 04.08. American Society for Testing and Materials, Philadelphia, PA.

American Society for Testing and Materials, 1990. "Standard Recommended Practice for the Description of Soils-Visual Manual Procedure.” D 2488-90. In: 1990 Annual book of ASTM standards. Vol. 04.08. American Society for Testing and Materials, Philadelphia, PA.

ASTM, see American Society for Testing and Materials.

Bechtel Nevada, 1998. Hydrogeologic Characterization of U-3bh Collapse Zone: Data Report. DOE/NV/11718--198. Prepared for the U.S. Department of Energy, Nevada Operations Office, February 1988. Las Vegas, NV.

Bechtel Nevada, 2005a. Site Characterization Data from the U3ax/bl Exploratory Boreholes at the Nevada Test Site. DOE/NV 11718--003-REV.1. Prepared for the U.S. Department of Energy, National Nuclear Security Administration Nevada Site Office, August 2005. Las Vegas, NV.

Bechtel Nevada, 2005b. Hydrogeologic Characterization of U-3at Collapse Zone. DOE/NV/11718--199-REV.1. Prepared for the U.S. Department of Energy, National Nuclear Security Administration Nevada Site Office, August 2005. Las Vegas, NV.

Blake, G. R., and K. H. Hartge, 1986. "Bulk Density.” In: Klute, A. L. (ed). Methods of Soil Analysis, Part 1, Physical and Mineralogical Methods. $2^{\text {nd }}$ Ed. American Society of Agronomy, Madison, WI.

BN, see Bechtel Nevada.

Burg, W. P., 1994. "Liquid Scintillation Instrumentation Method.” In: DOE Methods for Evaluating Environmental and Waste Management Samples. DOE/EM-089T, Rev. 2.

Conca, J. L., and J. V. Wright, 1992. "Diffusion and Flow in Gravel, Soil and Whole Rock". Applied Hydrology, 1:5-24.

Detty, T. E., D. P. Hammermeister, D. O. Blout, M. J. Sully, R. L. Dodge, J. Chapman, and S. W. Tyler, 1993. "Water Fluxes in a Deep Arid-Region Vadose Zone." Eos Trans. AGU, 74(43), Fall Meet. Suppl.297.

DOE, see U.S. Department of Energy. 
Elletson, L. W., and K. R. Johnejack, 1995. Waste Inventory Report for the U3ax/bl Disposal Unit at the Nevada Test Site. DOE/NV/11432-193. Prepared for U.S. Department of Energy, Nevada Operations Office, Las Vegas, NV.

Gonfiantini, R., 1981. The Del-Notation and the Mass Spectrometric Measurement Techniques. International Atomic Energy Agency. Technical Report Series No. 210.

Hawkins, W. L., Los Alamos National Laboratory 1994. Written communication. Subject: Data Report and Review: U3ax/bl Characterization and Closure. Los Alamos, NM. Included in this document as Attachment A.

Hoffman, R. N. A., 1963. "A Technique for the Determination of Capillary Pressure Curves Using a Constantly Accelerated Centrifuge.” Soc. Pet. Eng. Jour. 3:227-235.

Plannerer, H. N., 1996. Siting Criteria for Angle Drilling Under the U-3ah/at Disposal Unit. Los Alamos National Laboratory Report LA-UR-96-1679.

Raytheon Services Nevada, 1991. Written communication. Subject: Nevada Test Site Drilling and Mining Summary. Las Vegas, NV.

Shott, G. J., V. Yucel, M. J. Sully, L. E. Barker, S. E. Rawlinson, and B. A. Moore, 2000. Performance Assessment/Composite Analysis for the Area 3 Radioactive Waste Management Site at the Nevada Test Site, Nye County, Nevada. DOE/NV--491-REV 2.1, October 2000. Bechtel Nevada, Las Vegas, NV.

Special Operations and Research Division of Air Resources Laboratory. Website containing archived data accessed June 22, 2005.

$<$ http://www.sord.nv.doe.gov/products/climate/monthly_temp_summaries/meda-03/1996/>

Snyder, K. E., G. E. Byers, and R. D. Van Remortel, 1996. Handbook of Laboratory Methods of Soil Analysis. DOE/NV/11718--074. Prepared for U.S. Department of Energy, Nevada Operations Office, Las Vegas, NV.

Tyler, S. W., J. B. Chapman, S. H. Conrad, D. P. Hammermeister, D. O. Blout, J. J. Miller, M. J. Sully, and J. M. Ginanni, 1996. "Soil-Water flux in the Southern Great Basin, United States: Temporal and Spatial Variations over the Last 120,000 Years." Water Resour. Res. 32:1481-1499.

U.S. Congress, Office of Technology Assessment, 1989. The Containment of Underground Nuclear Explosions. OTA-ISC-414. U.S. Government Printing Office, Washington, D.C.

U.S. Department of Energy, 1996a. Final Environmental Impact Statement for the Nevada Test Site and Off-Site Locations in the State of Nevada. DOE/EIS-0243, August 1996. Las Vegas, NV. 
U.S. Department of Energy, 1996b. Guidance for a Composite Analysis of the Impact of Interacting Source Terms of the Radiological Protection of the Public from Department of Energy Low-Level Waste Disposal Facilities. Washington, D.C.

U.S. Department of Energy, 1988. DOE Order 5820.2A, "Radioactive Waste Management." Washington, D.C. Superseded by DOE Order 435.1.

U.S. Department of Energy, 1999. DOE Order 435.1, "Radioactive Waste Management." Washington, D.C. July 9, 1999.

U.S. Department of Energy Nevada Operations Office, 2000a. Closure Plan for Corrective Action Unit 110: Area 3 RWMS U-3ax/bl Disposal Unit, Nevada Test Site, Nevada. DOE/NV--647. Las Vegas, NV.

U.S. Department of Energy Nevada Operations Office, 2000b. United States Nuclear Tests, July 1945 through September 1992. DOE/NV--209-REV 15. Las Vegas, NV.

U.S. Department of Energy, National Nuclear Security Administration Nevada Operations Office, 2001. Closure Report for Corrective Action Unit 110: Area 3 RWMS U-3ax/bl Disposal Unit, Nevada Test Site, Nevada. DOE/NV--733. Las Vegas, NV. 
This page intentionally left blank. 


\title{
ATTACHMENT A
}

\section{Data Report and Review: U3ax/bl Characterization and Closure}

\author{
W. L. Hawkins \\ Los Alamos National Laboratory \\ 1994
}




\section{Data Report and Review U3ax/bl Site Characterization and Closure}

Ward L. Hawkins

Earth and Environmental Sciences Division

Los Alamos National Laboratory 


\section{TABLE OF CONTENTS}

\begin{tabular}{||l|c|}
\hline \multicolumn{1}{|c|}{ Title } & Page \\
\hline List of Tables & 3 \\
\hline List of Figures & 3 \\
\hline List of Appendices & 4 \\
\hline I. Purpose and Scope & 5 \\
\hline II. Background & 5 \\
\hline III. General Operations & 7 \\
\hline IV. Area 3 RWMS Hydrogeologic Setting & 9 \\
\hline V. U3ax and U3bl Emplacement Operations & 10 \\
\hline VI. U3ax and U3bl Event Information & 11 \\
\hline VII. U3ax and U3bl Hydrogeologic Information & 12 \\
\hline VIII. Time Domain Reflectometry Measurements & 13 \\
\hline IX. Summary & 13 \\
\hline Acknowledgements & 14 \\
\hline Disclaimer & 14 \\
\hline References & 14 \\
\hline Appendices & 32 \\
\hline
\end{tabular}




\section{List of Tables}

\begin{tabular}{||l|c|}
\hline \multicolumn{1}{|c|}{ Title } & Page \\
\hline 1. RWMS event emplacement hole construction data & 16 \\
\hline 2. Post event surface collapse and radiation release information & 17 \\
\hline 3. Summary of hole construction data for all the holes drilled for the U3ax event & 18 \\
\hline 4. Summary of hole construction data for all the holes drilled for the U3bl event & 19 \\
\hline 5. U3ax Lithologic Log & 20 \\
\hline 6. Borehole measurements in all holes for the U3ax and U3bl events & 21 \\
\hline 7. Explanation of geophysical logging measurements listed in Table 6 & 22 \\
\hline
\end{tabular}

List of Figures

\begin{tabular}{|c|c|}
\hline Title & Page \\
\hline 1. Standard vertical post-shot drill rig and equipment & 23 \\
\hline 2. Drilling and surface construction plan for U3ax & 24 \\
\hline 3. Surface and subsurface location of drill holes at U3ax & 25 \\
\hline 4. U3ax satellite holes & 26 \\
\hline 5. Surface construction plan for U3bl & 27 \\
\hline 6. Surface and subsurface location of drill holes at U3bl & 28 \\
\hline 7. U3bl satellite holes & 29 \\
\hline 8. Collapse craters for U3ax and U3bl & 30 \\
\hline 9. Alluvium isopch map & 31 \\
\hline
\end{tabular}




\section{List of Appendices}

\begin{tabular}{||c|l|}
\hline Appendix & \multicolumn{1}{|c|}{ Title } \\
\hline A & Hole histories for RWMS emplacement holes \\
\hline B & Construction information for all holes drilled within the RWMS \\
\hline C & Boreholes measurements made in the RWMS emplacement holes \\
\hline D & Hole histories for holes drilled for the U3ax event \\
\hline E & Hole histories for holes drilled for the U3bl event \\
\hline F & U3bl site characterization \\
\hline
\end{tabular}




\section{Purpose and Scope}

The Los Alamos National Laboratory has been funded by the Special Projects Section, Environmental Restoration and Technology Development Department, REECO, to produce a data report in support of a site characterization and closure program for the U3ax/bl waste disposal unit (WDU). Included in the report is general information regarding field operations at the site of these underground nuclear detonation events, specific information on the U3ax/b/ WDU, and data on the other event sites of the Area 3 Radioactive Waste Management Site (RWMS).

The task is a compilation of data through a search of the literature, archives, and databases for operational, geological, hydrological, borehole, and event information in the vicinity of U3ax/bl. Emphasis is on site-specific characterization information which will be submitted with the closure plan and used to develop a conceptual model of the vadose zone (U3ax/bl Waste Disposal Unit).

\section{Background}

Testing of nuclear explosives has played a vital role in support of the national policy of nuclear deterrence and has enabled the U. S. Department of Energy to meet its statutory responsibility. The Nevada Test Site (NTS) was established on December 18, 1950 by President Truman as a continental area for the testing of nuclear devices. The first underground test was conducted in 1957.

The Limited Test Ban Treaty (LTBT) ratified by the United States, Great Britain and the Soviet Union in 1963 prohibited testing except under the ground surface. Since 1976 the United States has adhered to the Threshold Test Ban Treaty (TTBT), which limits the yield of any nuclear weapons test to 150 kilotons. After a successful Joint Verification Experiment in 1988, the US and the USSR agreed to techniques for treaty verification and the TTBT was ratified by both sides in 1990 .

When an underground nuclear explosion occurs, the shock wave dynamically vaporizes and melts the rock in the immediate vicinity of the detonation point. The 
shock-induced outward motion and high internal cavity pressure (the cavity is filled with gas which is mostly steam) cause the cavity to expand until the pressure has decreased to the point that the rock can no longer be deformed. The material then rebounds to form a large compressive stress field around the cavity. After cavity growth ceases and internal pressure drops below the amount necessary to support the overburden, the rock above the cavity falls into the void forming a rubble chimney which, depending upon the yield and overburden characteristics, may extend to the surface forming a subsidence crater.

Prior to the commencement of underground testing in 1957, the importance of hydrogeologic characterization for safety and environmental protection was recognized (Eckel, 1968). An intensive regional geologic mapping effort took place over much of the NTS between 1960 and 1965. Most of this early work was accomplished by the U. S. Geological Survey (Byers et al, 1989). Prior to 1971, event specific characterization was usually for operational considerations and explosion diagnostics. Samples were limited to drill bit cuttings collected periodically during drilling operations and an occasional bottom hole core. These techniques resulted in only generally representative samples because of material mixing. Borehole geophysical measurements, if made, were usually only in the vicinity of the explosion point and, again, the objective was to obtain data for explosion evaluation not detailed geologic site characterization (Houser, 1968).

Site specific hydrogeologic characterization efforts began in earnest following the BANEBERRY underground nuclear explosion in December 1970. Approximately 3.5 minutes after detonation, a large amount of radioactive gas and debris began venting through a fissure in the ground and continued venting for about 2 hours. Studies conducted shorly after the event identified the existence of geologic conditions which resulted in this prompt dynamic release (Glenn, et al, 1983,Terhune, et al, 1977, and USGS, 1974,). This experience indicated the need for a better understanding of the hydrogeologic setting. Following BANEBERRY, the U.S. Department of Energy (then the Atomic Energy Commission) established the Containment Evaluation Panel (CEP) 
to review all aspects of a proposed test to prevent releases of radioactivity to the atmosphere (USDOE, 1986).

Typically, results of detailed interdisciplinary hydrogeologic investigations for each test location are included in a Containment Prospectus which is thoroughly examined by the CEP (Howard, 1983). Surface data include regional and site specific geologic maps, geophysical surveys (gravity, magnetic and seismic), and fracture patterns produced by previous detonations. Subsurface data are obtained from geophysical logs, rock and fluid samples, and borehole photography. Most subsurface data are from the large diameter emplacement holes, but nearby small diameter $(0.1$ to $0.3 \mathrm{~m})$ exploratory or satellite holes are sometimes available for characterization purposes. Stratigraphy, lithology, geologic structure, hydrology, geochemistry, petrography, and physical properties are integrated into a comprehensive interpretation which, when combined with experiment design data, provide a model that can be used to assure every potential release concern has been addressed and complete containment is expected.

\section{General Operations}

Emplacement hole construction data for the seven event sites in the Area 3 RWMS are summarized in Table 1. Each of the RWMS emplacement holes (large diameter holes constructed to accommodate the nuclear explosive, and associated hardware, instrumentation and cables) was drilled with direct circulation. Two of the seven holes (U3bg and U3bh) were drilled with air, the others were drilled with a low fluid loss mud. Appendix $A$ is the hole histories for the seven RWMS emplacement holes. These emplacement holes were drilled in stages beginning with a smaller diameter bit and then opened up with a larger bit to the final diameter. All of the emplacement holes were completely cased. Following insertion of the device and diagnostic instrumentation hardware, and associated cables, the holes were backfilled to the surface by dumping various combinations of fine and coarse material into the hole from ground level. 
Appendix $B$ is a summary of all the holes drilled for each event of the Area 3 RWMS. Satellite holes (pre-event holes drilled for the installation instrumentation to measure effects of the explosion) were drilled at each of the event sites. These holes were drilled prior to the events with mud and/or air. Air drilling included some water and soap to improve the lifting capacity of the circulating fluid. Some of the satellite holes were cased. After the installation of the instruments and cables, the holes were backfilled to the surface, often cemented in the upper section.

Post-shot holes were drilled after each of the RWMS events (Appendix B). These holes were drilled to retrieve, as quickly as possible, a sample from the working point region for radiochemical analyses. The two post-shot holes at U3ah were completely cased, all the other post-shot holes had only a cemented in surface casing down to less than $30 \mathrm{~m}$ (100 ft). Only one post-shot hole in the Area 3 RWMS (U3ax PS 6) was started outside the crater and directionally drilled toward the sampling zone at the bottom of the cavity. The others were vertically drilled within the collapse crater. All of the post-shot holes were drilled with mud. Circulation to the surface was avoided to prevent contaminated drilling fluids from reaching the ground level. Occasionally the edge of the collapse chimney was thought to have been detected either by drilling rate changes or slippage of drill pipe into a void. These occurrences were rarely documented.

Vertically drilled post-shot holes (Figure 1 ) in the crater were probably not backfilled but were left with a welded cap, blind flange or slide (abandonment) valve installed on the top of the casing (Butler, 1984). A blind flange is a bolted-on cap. The abandonment valves are off-the-shelf slide valves widely used in the petroleum industry to provide a pressure-tight seal at the top of a well. Post-shot holes directionally drilled from outside the crater (U3ax PS 6) were generally plugged to the surface. Records of activities following the drilling and sampling phase are poor, if they exist at all. Drilling and sampling hardware may have been left in some of these holes without being reported. 
Appendix $C$ is a listing of the borehole geophysical measurements made in the RWMS emplacement holes. The majority of the logs were directional surveys to map the location of the hole. Some useful information may be obtained from these logs however, these logs are paper records and will have to be retrieved from archives. Core samples, primarily bottom hole cores, were retrieved from U3ax, U3az, U3ah, and U3at, and are stored at the USGS core library.

Table 2 is a summary of event information relevant to the RWMS. Two of the events (FISHER, U3ah, and ACUSHI, U3bg) resulted in very minor releases of radioactivity. The release at FISHER was contained within a sampling line and the release at ACUSHI was right at Surface Ground Zero suggesting flow up the cased hole, perhaps associated with the downhole cables. Crater dimensions and collapse times for these events are normal for events of this type.

\section{Area 3 RWMS Hydrogeologic Setting}

The Area 3 RWMS is in a portion of Yucca Flat where there is limited information from the deeper Alluvium and Tertiary volcanic rocks. The most complete (although almost 30 year old) hydrogeological data in the area is from U3cn the BILBY site some $1570 \mathrm{~m}(5150 \mathrm{ft})$ to the north (Garber and Johnston, 1967). In the vicinity of U3cn the alluvium is about $200 \mathrm{~m}(700 \mathrm{f})$ to $290 \mathrm{~m}$ ( $950 \mathrm{ft}$ ) thick and the base of the alluvium is several hundred meters above the water table and regional zone of saturation. The welded, partially welded, nonwelded, and bedded Teriary tufts are more than $600 \mathrm{~m}$ $(2,000 \mathrm{ft})$ thick. Zeolitization of the tuffs has occurred both above and below the water table, and this zone of alteration is a fractured confining unit that can be as much as $450 \mathrm{~m}(1,500 \mathrm{ft})$ thick. Groundwater movement through this unit is believed to occur chiefly through fractures, at least under natural hydraulic gradients. Because of the extremely high bulk capillarity, the interstices of this zone of zeolitization are nearly fully saturated even hundreds of meters above the water table (Hoover, 1968).

Several test holes have penetrated carbonate rocks of Paleozoic age below the major part of Yucca Flat. These carbonate rocks form an extensive and very 
permeable aquifer. Water in this aquifer appears to be moving slowly to the south. The piezometric surface is approximately $725 \mathrm{~m}(2,380 \mathrm{ft})$ above mean sea level and slightly lower than the water table in the over lying zeolitized tuff.

\section{U3ax and U3bl Emplacement Operations}

Site U3ax was used on 7 May 1962 for the PACA experiment. Figure 2 is the drilling and surface construction plan for U3ax. The location, horizontal displacement and vertical deviation of all the holes drilled at the U3ax site are shown in Figure 3. Table 3 is drill hole information for the holes drilled for the PACA event. The post-shot holes were probably abandoned as stated above (no specific information could be found). This means there could be holes which were drilled in the crater after the event and were left with only a seal at the top of the surface casing. The satellite holes that were used for PACA (Figure 4) were planned to be backfilled with sand to $-30 \mathrm{~m}$ $(100 \mathrm{ft})$ from the surface then cemented to the surface (no "as-built" information was found). Appendix D is the hole histories for the Satellite and Post-shot holes for PACA.

Following installation of the device and diagnostics rack into the PACA emplacement hole (which was consumed within the vaporizing/melting radius of the explosion) and the 23 downhole cables, the hole was backfilled. The first layer of backfill was $5 \mathrm{~m}^{3}$ (175 $\mathrm{ft} 3$ ) of dust-free sand, then the hole was filled with "Mill-Run" cement sand to $3 \mathrm{~m}$ (10 ft) from the surface. A gypsum cement ("Calseal") plug was poured as a gas seal in the the upper $3 \mathrm{~m}(10 \mathrm{ft})$ of stemming at the top of the hole. Specifications for the cement sand were $100 \%$ passing $0.01 \mathrm{~m}(3 / 8 \mathrm{inch})$ screen and less than $5 \%$ passing a \#10 screen. The water contentis estimated as between $1 \%$ and $3 \%$.

There was an interesting incident documented following the backfilling at U3ax emplacement hole (Engstrom, 1993, Personnel Communication):

"...on the "Paca" event in U3-ax on May 7, 1962. Stemming of this hole was also completed late in the afternoon of May 6, and as the crews were cleaning up at $G Z$, there was a decided rumble which sounded like a muffled explosion far underground. This started the 
Yucca Flats Track Meet as everyone around the hole took off at a dead run in different directions. Upon their sheepish return, the stemming was found to have slumped some 20-feet."

Site U3bl was used on 24 August 1962 for the BOBAC experiment. Figure 5 is the surface construction plan for U3bl. The location, horizontal displacement and vertical deviation of the holes used at the U3bl site are shown in Figure 6. Table 4 is drill hole information for the holes drilled for the BOBAC event. The post-shot holes were probably abandoned as stated above (no specific information could be found). The satellite holes that were used for BOBAC (Figure 7) were planned to be backfilled with sand to $-38 \mathrm{~m}$ (125 ft) from the surface then cemented to the surface with concrete (no "as-built" information was found). Appendix $E$ is the hole histories for the Satellite and Post-shot holes for BOBAC.

Following installation of the device and diagnostics rack into the BOBAC emplacement hole (which was consumed within the vaporizing/melting radius for the explosion), along with the 38 downhole cables, the hole was backfilled. After the first layer (16 $\mathrm{m}^{3}$ of magnetite sand for instrument sheilding) was installed, the hole was filled with sand. Two-meter $(6 \mathrm{ft})$ thick fines layers were placed every $30 \mathrm{~m}(100 \mathrm{H})$ above the magnetite. A gypsum cement ("Calseal") plug was poured as a gas seal the upper $3 \mathrm{~m}$ (10 ft) of stemming. Specifications for the sand were $100 \%$ passing $0.01 \mathrm{~m}$ ( $3 / 8$ inch) screen and less than $5 \%$ passing a $\# 10$ screen. Fines material had to all pass a \#3 screen. The water contentis estimated between $1 \%$ and $2 \%$.

There were several recorded instances of bridging, and post-backfilling slumping of the backfill material upon collapse of the bridge. Slumping of the backfill at PACA was believed to have been the result of rapidily filling the hole from the surface which resulted in the bridging. During the 15 months following PACA the backfilling procedure evolved, primarily through trail and error, to a prescribed rate of filling which was prevented bridging. The use of alternating layers of fine and coarse grained material at BOBAC was part of this evolutionary process. 
VI. U3ax/bl Event Information

Table 2 includes event information for the PACA and BOBAC events. Figure 8 is contour maps of the craters. None of the phenomena associated with these detonations suggests anything unusual about the sites. There was no release of radioactivity to the surface. They both had cavity collapase and surface crater formation at typical times. Events conducted during this period of time did not use current containment practices of cable gas blocking and installation of impermeable plugs; however, the use of alternating coarse and fines layers at BOBAC is similar to modern practices.

VII. U3ax/bl Hydrogeologic Information

As for the entire RWMS, the hydrological and geological information is very limited for U3ax/bl. Table 5 is the lithologic log produced by the US Geological Survey for U3ax (Cole and Williams, 1962). Table 6 is a listing of the borehole measurements and geophysical logs from the two sites. These data are not in digital form and are stored in DOE archives. There are cuttings samples available from both holes and bottom hole core from U3ax. Aerial photos were taken before and after each event.

Appendix $F$ is a detailed geological site characterization prepared in 1983 for a containment prospectus for emplacement site U3lb, which is some $870 \mathrm{~m}$ (2855 ft) to the north-northeast of the U3ax/b/ WDU. This emplacement hole is in unsaturated tuffaceous alluvium. The hole construction history does not indicate any geologic pecularities encountered during drilling operations for this $1.32 \mathrm{~m}$ (52 in) diameter, $243.8 \mathrm{~m}(800 \mathrm{ft})$ deep hole.

Surface features of interest in the area of U3lb are shot-related radial and concentric fractures and the Area 3 fault. U3lb did not penetrate the tuffs so the stratigraphy below the alluvium is projected from nearby holes, primarily U3kx which is in a very similar structural setting. Figure 9 is an alluvium isopach map produced by the LANL Geologic Support Group of RSN (Raytheon Services of Nevada) (Drellack, 1988, Personal Communication), it shows the lack of information regarding 
the thickness of the alluvium in the region of the Area 3 RWMS. The Paleozoic surface is estimated to be at a depth of $1040 \mathrm{~m}$ (3410 ft) and the alluvium/tuff contact is predicted to be at a depth of $275 \mathrm{~m}$ (900 ft). Depth to the water table is approximately $490 \mathrm{~m}(1600 \mathrm{ft})$. The major structural feature is the Area 3 fault $\mathrm{mm}(\mathrm{ft})$ to the east, but there is no surficial evidence of this fault near U3lb.

The U3lb caliper log shows a very smooth hole for alluvium. No zones of low resistivity that might suggest clay layers were noted on the electric log. Density log data indicates an average bulk density of $1.64 \mathrm{Mglm}^{3}$ for the entire empalcement hole. The material properties for the medium at U3lb are normal for unsaturated Area 3 alluvium. Depth to the water table was estimated to be $500 \mathrm{~m}$ (1640 ft).

VIII. Time Domain Reflectometry Measurements

Time Domain Reflectometry (TDR) is a technique that has been used to determine the length of unbroken cable. An electrical pulse is sent along the cable. Where the cable is damaged, the pulse reflects back to the source. Through calculations using the measured round-trip travel time for the pulse and the known conductance characteristics of the cable a length can be determined.

TDR data have been used to estimate the length of downhole cables following an underground test in an attempt to learn something about cavity collapse height and position of backfill material in the emplacement hole. In some cases this information has been useful in a supportive role when combined with other information such as predicted collapse phenomena and known condition of downhole instrumentation. In most cases, the information has been ambiguous, and inconsistent with other more reliable data. For example, TDR has shown cables damaged well above the upper limit of a subsurface collapse while other cables are undamaged well into the collapse rubble. It would be difficult to defend any interpretation of chimney and collapse features with only this data. 
IX. Summary

An examination of the data included in this report suggests that the operations and hydrogeologic setting for the U3ax/bI Waste Disposal Unit are typical for an event conducted in this time frame and in this part of Yucca Flat. The events were not unusual either in the downhole hardware or the method of emplacement. All of the holes within the average crater radius were stemmed such as satellite holes. Postshot holes were almost entirely uncased and were probably left unplugged but with some form of closure at the top of the short surface casing.

Acknowledgments

The author would like to thank M. A. Mathews, EES-3 and D. R. Engstrom DX-14 for their contributions and review.

\section{Disclaimer}

This report was prepared as an account of work sponsored by an agency of the United States Government. Neither the United States Government nor the University of California nor any of their employees, makes any warranty, express or implied, or assumes any legal liability or responsibility for the accuracy, completeness, or usefulness of any information, apparatus, product, or process disclosed, or represents that its use would not infringe privately owned rights. Reference herein to any specific commercial product, process, or service by trade name, trademark, manufacturer, or otherwise, does not necessarily constitute or imply its endorsement, recommendation, or favoring by the United States Government or any agency thereof. The views and opinions of authors expressed herein do not necessarily state or reflect those of the United States Government or any agency thereof.

\section{References}

Butler, M. W., 1984, Postshot Drilling Handbook, Univ. of California, Lawrence Livermore National Laboratory Report, M-148, 50 p.

Byers, F. M., Jr., Carr, W. J., and Orkild, P. P., 1989, Volcanic Centers of Southwestern 
Nevada: Evolution of Understanding, 1960-1988, Journal of Geophysical Research, Vol. 94, No. B4, pp 5908-5924.

Cole, T. H., and Williams, W. P., 1962, The Lithology of the U3-ax Drill Hole Site, Area 3, Nevada Test Site, U. S. Geological Survey, Technical Letter, Yucca-16.

Eckel, E. B, 1968, Development of Geologic Knowledge at Nevada Test Site in Nevada Test Site, The Geological Society of America, Memoir 110, E. B. Eckel, editor.

Garber, M. S., and Johnston, R. H., 1967, A Summary of Lithologic Data, Aquifer Tests, and Construction of Hydraulic Test Well U3cn-5, Nevada Test Site: U. S. Geological Survey Technical Letter: NTS 200.

Glenn, D. H., Rambo, J. T., and Terhune, R. W., 1983, Calculational Examination of the BANEBERRY Event - Addendum, Proceedings of the Monterey Containment Symposium, Monterey, CA, August 26-28, 1981, Los Alamos National Laboratory Report LA-9211-C, Vol. 1, B. C. Hudson, E. M. Jones, C. E. Keller, and C. W. Smith, compilers, pp $293-304$.

Hoover, D., 1968, Genesis of Zeolites, Nevad Test Site, The Geological Society of America, Memoir 110, E. B. Eckel, editor.

Houser, F. N, 1968, Underground Nuclear Testing in Nevada Test Site, The Geological Society of America, Memoir 110, E. B. Eckel, editor.

Howard, N. W., 1983, LLNL Site Characterization for Containment of Nuclear Tests, Lawrence Livermore National Laboratory Report UCRL-53446.

Terhune, R. W., Glenn, H. D., Burton, D. E., McKague, H. L., and Rambo, J. T., 1977, Calculational Examination of the BANEBERRY Event, Lawrence Livermore National Laboratory Report UCRL-52365.

USDOE, 1986, Containment Evaluation Charter, United States Department of Energy, Nevada Operations Office, Las Vegas, Nevada, revised June 1, 1986.

USGS, 1974, Results of Exploration of Baneberry Site, Early 1971, U. S. Geological Survey Report USGS-474-145. 


\begin{tabular}{|l|c|c|c|c|c|c||}
\hline Hole & $\begin{array}{c}\text { Northing } \\
(\mathrm{f})\end{array}$ & $\begin{array}{c}\text { Easting } \\
(\mathrm{ft})\end{array}$ & $\begin{array}{c}\text { Drilled } \\
\text { Depth } \\
(\mathrm{m})\end{array}$ & $\begin{array}{c}\text { Hole } \\
\text { Diamater } \\
(\mathrm{m})\end{array}$ & $\begin{array}{c}\text { Casing } \\
\text { Depth } \\
(\mathrm{m})\end{array}$ & $\begin{array}{c}\text { Casing } \\
\text { Inner Dia. } \\
(\mathrm{m})\end{array}$ \\
\hline U3ah & 836287 & 686481 & 370.3 & 0.66 & 368.2 & 0.61 \\
\hline U3at & 835799 & 686829 & 309.4 & 1.07 & 306.3 & 0.74 \\
\hline U3ax & 836550 & 687258 & 267.3 & 1.07 & 265.1 & 0.74 \\
\hline U3az & 835803 & 687693 & 268.8 & 1.07 & 265.1 & 0.74 \\
\hline U3bg & 836400 & 688400 & 329.2 & 1.07 & 265.4 & 0.74 \\
\hline U3bh & 835600 & 688401 & 329.2 & 1.07 & 265.1 & 0.74 \\
\hline U3bl & 836399 & 687600 & 211.2 & 1.22 & 208.7 & 0.91 \\
\hline \hline
\end{tabular}

Table 1. Hole construction information for the seven event emplacement holes in the Area 3 RWMS. After insertion of the device and the diagnostics hardware the holes were backfilled to the surface. (U3bg and U3bh were drilled to $329.2 \mathrm{~m}$ with a $0.66 \mathrm{~m}$ diameter bit but they were only opened up to install casing to just below the casing depth.) 


\begin{tabular}{||c|c|c|c|c|c|c|c|}
\hline & & & & Collapse & Crater & Crater & Crater \\
\hline Hole & Event & Date & $\begin{array}{c}\text { DOB } \\
(\mathrm{m})\end{array}$ & $\begin{array}{c}\text { Time } \\
(\mathrm{min})\end{array}$ & $\begin{array}{c}\text { Radius } \\
(\mathrm{m})\end{array}$ & $\begin{array}{c}\text { Diameter } \\
(\mathrm{m})\end{array}$ & $\begin{array}{c}\text { Volume } \\
(\mathrm{m} 3)\end{array}$ \\
\hline U3ah & FISHER & $12 / 3 / 61$ & 363 & 27.5 & 89 & 178 & \\
\hline U3at & JERBOA & $3 / 1 / 63$ & 301 & 35.3 & 85 & 168.9 & 246187 \\
\hline U3ax & PACA & $5 / 7 / 62$ & 258 & 15.6 & 70 & 138.4 & 88153 \\
\hline U3az & DORMOUSE PRIME & $4 / 5 / 62$ & 260 & 8.6 & 80 & 158.5 & 230896 \\
\hline U3bg & ACUSHI & $2 / 8 / 63$ & 260 & 21.6 & 79 & 156.7 & 182729 \\
\hline U3bh & HYRAX & $9 / 14 / 62$ & 216 & 7.9 & 78 & 155.4 & 168967 \\
\hline U3bI & BOBAC & $8 / 24 / 62$ & 195 & 8.2 & 61 & 121.9 & 140678 \\
\hline \hline
\end{tabular}

Table 2. Event surface collapse data and crater dimensions. FISHER and ACUSHI seeped small amounts of radiation to the ground surface at the test location. 


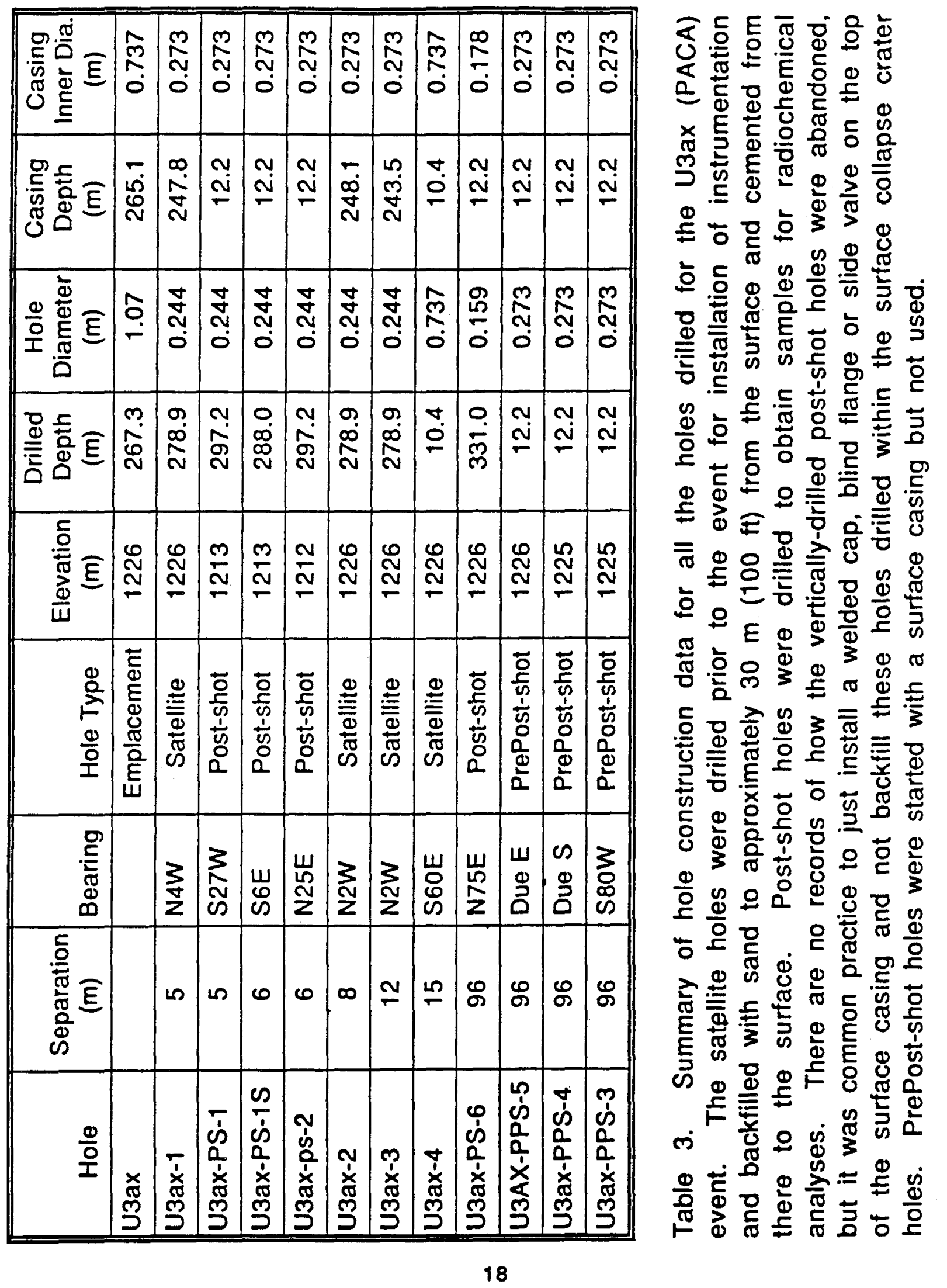




\begin{tabular}{|c|c|c|c|c|c|c|c|c|}
\hline 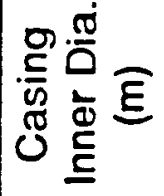 & & 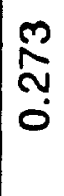 & 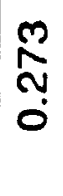 & $\underset{\sim}{\stackrel{n}{\sim}}$ & 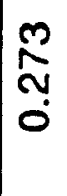 & 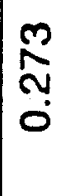 & 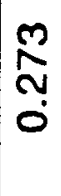 & 管 \\
\hline 号乒 & $\stackrel{N}{\infty}$ & $\stackrel{0}{=}$ & $\stackrel{\varphi}{=}$ & $\begin{array}{l}m \\
\mathscr{O} \\
\mathscr{V}\end{array}$ & $\begin{array}{l}n \\
\mathscr{I} \\
\mathscr{q}\end{array}$ & $\begin{array}{l}n \\
\dot{0} \\
\dot{\sigma}\end{array}$ & $\begin{array}{l}m \\
0 \\
0 \\
\square\end{array}$ & $\begin{array}{l}N \\
\sim \\
\sim\end{array}$ \\
\hline 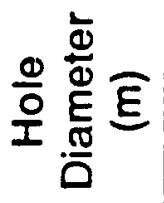 & $\frac{0}{0}$ & 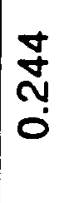 & 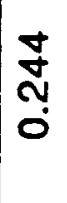 & $\begin{array}{l}\stackrel{\nabla}{\Delta} \\
\stackrel{0}{0}\end{array}$ & ָั & 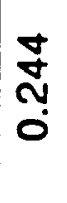 & $\begin{array}{l}\stackrel{d}{\Delta} \\
\stackrel{v}{0} \\
0\end{array}$ & 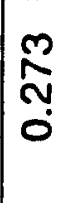 \\
\hline 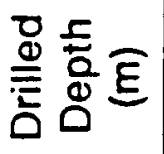 & $\frac{N}{\tilde{N}}$ & ঙ্் & $\begin{array}{l}0 \\
\dot{\mathscr{D}} \\
\stackrel{N}{N}\end{array}$ & $\begin{array}{l}0 \\
\stackrel{0}{0} \\
\stackrel{0}{N}\end{array}$ & $\begin{array}{l}0 \\
\mathscr{8} \\
\stackrel{0}{N}\end{array}$ & $\begin{array}{l}0 \\
0 \\
0 \\
\end{array}$ & 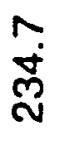 & $\underset{N}{N}$ \\
\hline 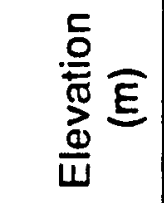 & $\stackrel{\mathscr{N}}{\underset{N}{N}}$ & $\stackrel{\omega}{\sim}$ & $\stackrel{\omega}{\sim}$ & $\stackrel{\mathscr{N}}{\underset{N}{N}}$ & $\stackrel{\mathscr{N}}{\mathrm{N}}$ & $\stackrel{0}{\sim}$ & $\stackrel{\mathscr{N}}{\underset{N}{N}}$ & $\stackrel{\mathscr{N}}{\underset{N}{N}}$ \\
\hline $\begin{array}{l}0 \\
\stackrel{0}{2} \\
\frac{9}{1} \\
\frac{9}{I}\end{array}$ & 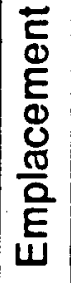 & $\begin{array}{l}\frac{0}{0} \\
\frac{1}{0} \\
\frac{1}{0} \\
0\end{array}$ & $\begin{array}{l}\frac{5}{0} \\
\frac{1}{0} \\
\frac{1}{c g} \\
0 \\
0 .\end{array}$ & 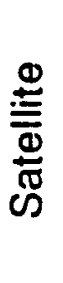 & 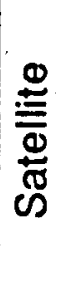 & $\frac{\Phi}{\stackrel{\Phi}{\Phi}}$ & $\frac{\stackrel{\Phi}{\Xi \Phi}}{\frac{\Phi}{\mathscr{D}}}$ & $\begin{array}{l}\frac{\sigma}{0} \\
\frac{c}{p} \\
\frac{1}{d} \\
0 \\
\frac{0}{0} \\
\frac{0}{2}\end{array}$ \\
\hline 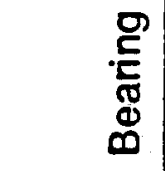 & & $\underset{\substack{\infty \\
\hdashline}}{3}$ & $\begin{array}{l}\text { Uू } \\
\stackrel{0}{Z}\end{array}$ & $\underset{\sim}{\mathbf{Z}}$ & $\frac{3}{2}$ & 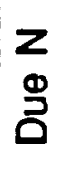 & $\begin{array}{l}W \\
\mathbb{1} \\
\stackrel{\infty}{Z}\end{array}$ & $\frac{3}{\frac{3}{2}}$ \\
\hline 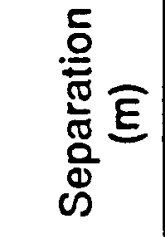 & 0 & in & $n$ & $\infty$ & $\mp$ & $\stackrel{\varphi}{ }$ & $\approx$ & $\dot{\sigma}$ \\
\hline $\begin{array}{l}\frac{D}{0} \\
\text { I }\end{array}$ & $\begin{array}{l}\overline{0} \\
\text { ต }\end{array}$ & $\begin{array}{l}\bar{s} \\
\frac{1}{0} \\
\frac{0}{3}\end{array}$ & 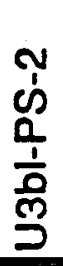 & $\begin{array}{l}\frac{1}{\circ} \\
\frac{0}{2}\end{array}$ & $\begin{array}{l}\frac{1}{5} \\
\frac{9}{2}\end{array}$ & $\begin{array}{l}\frac{1}{0} \\
\frac{9}{3}\end{array}$ & $\frac{\mathscr{n}}{\frac{1}{n}}$ & 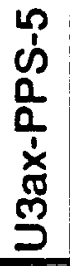 \\
\hline
\end{tabular}

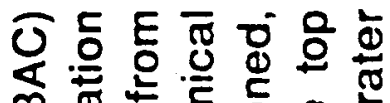

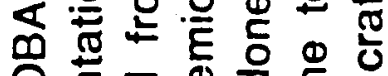

О 등 엉 읃

@

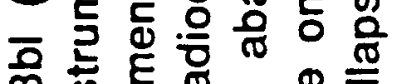

马.气

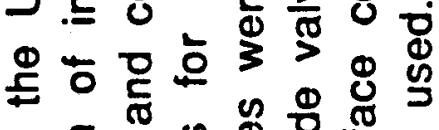

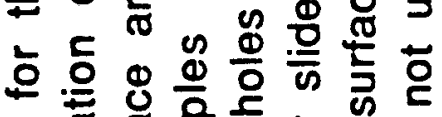

兽 离

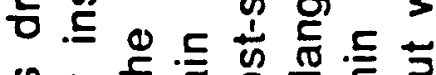

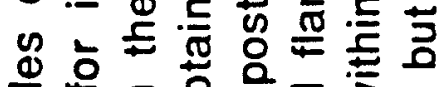

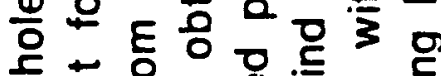

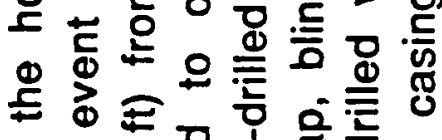

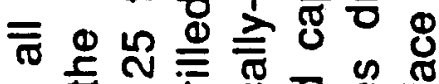

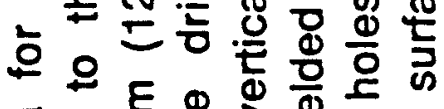

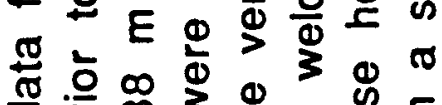

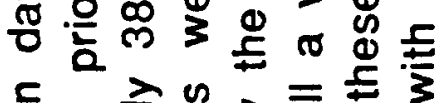

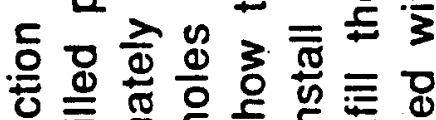

늘 至

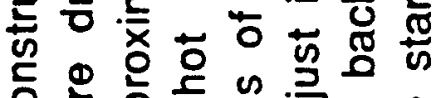

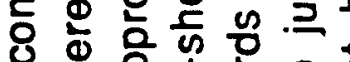

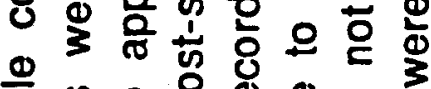

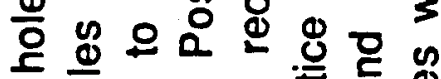

도을 은

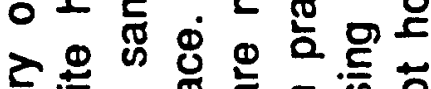

究产

E 焉 专 心

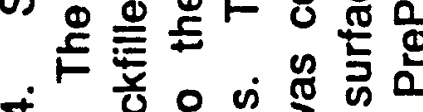

$\dot{0}$ 过

产 
Table 5

U3ax LITHOLOGIC LOG

(Cole and Williams,1962)

\begin{tabular}{|c|c|}
\hline Description & $\begin{array}{c}\text { Depth Interval } \\
(\mathrm{m})\end{array}$ \\
\hline $\begin{array}{l}\text { Tulfaceous sand. Tuff fragments, purple welded }(30 \%) \text {. White zeolitized and } \\
\text { partly welded }(50 \%) \text {. Pink and pale green }(5 \%) \text {. Quartz and feldspar crystals } \\
(5 \%) \text {. Lithic and rock fragments }(10 \%) \text {. Coarse to fine sands sizes, angular to } \\
\text { rounded }\end{array}$ & $3.1-36.6$ \\
\hline No samples collected & $36.6-103.6$ \\
\hline $\begin{array}{l}\text { Tulfaceous sand and gravel. Tuff fragments, purple welded ( } 35 \%) \text {, white, } \\
\text { zeolitized and welded }(35 \%) \text {, pink and other types ( }<5 \%) \text {. Quartz and } \\
\text { feldspar crystals }(<5 \%) \text {. Rock fragments, mostly basalt and quartzite }(20 \%) \text {. } \\
\text { Gravel to medium sand size, much coarser than } 3.1 \text { to } 36.5 \text { m interval, angular } \\
\text { to rounded }\end{array}$ & $103.6 \cdot 120.4$ \\
\hline $\begin{array}{l}\text { Tuffaceous sand. Tuff fragments, purple welded }(25 \%) \text {, white and light- } \\
\text { colored zeolitized and welded }(40 \%) \text {, brown fine-grained tutl }(10 \%) \text {, others } \\
(3 \%) \text {. Quartz and feldspar }(2 \%) \text {. Rock fragments }(20 \%) \text {. Coarse sand size, } \\
\text { angular to rounded. End of cuttings. }\end{array}$ & $120.4-137.2$ \\
\hline No samples collected. & $137.2-260.6$ \\
\hline $\begin{array}{l}\text { Tuffaceous sand and gravel. Tuff fragments, pale yellow and white, zeolitized } \\
(55 \%) \text {. Quartz and feldspar grains }(40 \%) \text {. Lithics, quartzite and argillite }(5 \%) \text {. } \\
\text { Mafic minerals, mainly magnetite }(1 \%) \text {. Grain sizes range from sitt to pebble } \\
\text { size, but the average is medium sand. Particles are angular to rounded. The } \\
\text { material is uncemented and the core crumbles easily when handled. Core } \\
\text { samples. }\end{array}$ & $260.6 \cdot 263.7$ \\
\hline
\end{tabular}

\begin{tabular}{|l|r|}
\hline \multicolumn{2}{|c|}{ Average Physical Properties for U3ax } \\
\hline Dry bulk density & $1.43 \mathrm{~g} / \mathrm{cc}$. \\
\hline Grain density or matrix density & $2.45 \mathrm{~g} / \mathrm{cc}$. \\
\hline Sample state bulk density & $1.77 \mathrm{~g} / \mathrm{cc}$. \\
\hline Saturation & 83 volume $\%$ \\
\hline Porosity & 42 volume $\%$ \\
\hline Water content & 20 weight $\%$ \\
\hline Magnetic susceptibility & $352 \times 10^{-6}$ cgs units. \\
\hline
\end{tabular}




\begin{tabular}{||l|l|}
\hline Hole & LOGS \\
\hline U3bI & DIR GYRO \\
\hline U3bl-PS-1 & DIR MAG, 2 HIGH INTENSITY GAMMA, TEMP \\
\hline U3bl-PS-2 & DIR MAG, HIGH INTENSITY GAMMA, TEMP \\
\hline U3bl-1 & DIR GYRO \\
\hline U3bl-2 & DIR GYRO \\
\hline U3bl-3 & NO LOGS \\
\hline U3bl-3s & DIR MAG \\
\hline
\end{tabular}

\begin{tabular}{||l|l|}
\hline U3ax & $\begin{array}{l}\text { CVL, DIR GYRO, ELOG, ELOG FOCUS, ELOG } \\
\text { IND, GR-N, TEMP }\end{array}$ \\
\hline U3ax-1 & CALIPER, DIR GYRO \\
\hline U3ax-ps-1 & DIR MAG, GAMMA \\
\hline U3ax-ps-1s & DIR MAG, GAMMA \\
\hline U3ax-ps-2 & DIR MAG, GAMMA \\
\hline U3ax-2 & CALIPER, DIR GYRO \\
\hline U3ax-3 & CALIPER, DIR GYRO \\
\hline U3ax-4 & NO LOGS \\
\hline U3ax-ps-6 & DIR MAG, GR-N, TEMP \\
\hline U3ax-pps-5 & NO LOGS \\
\hline U3ax-pps-4 & NO LOGS \\
\hline U3ax-pps-3 & NO LOGS \\
\hline
\end{tabular}

Table 6. Borehole measurments in all holes for the U3ax and U3bl events. (See Table 7 for explaination.) 
DIR GYRO = Directional Gyroscope This log is used in a directional survey of a borehole to acquire measurements of drift, azimuth, and inclination of a borehole with the vertical. Essentially maps the subsurface location of a borehole.

DIR MAG = Directional Magnetic Compass This log is used in a directional survey of a borehole. Essentially maps the subsurface location of a borehole.

HIGH INTENSITY GAMMA = Special gamma logging tool used in post shot holes. Measures high intensity gamma rays from nuclear explosions.

TEMP = Temperature logging tool measures the bore hole temperature.

$C V L=$ Continuous Velocity Log. This $\log$ is an acoustic tool that measures the formation compressional velocity. This information can be used to estimate the porosity, rock strength, and travel speed in the formation or rocks surrounding the borehole.

$E L O G=$ Electric Log. This log is a galvanic resistivitv tool that measures the short normal, the long normal, and the lateral rebistivity of the formation surrounding the borehole. This resistivity information can be used to estimate the porosity and saturation of the formation. It also can be used to locate clay.

ELOG FOCUS = Focussed Electric Log. This log is a galvanic guard electric logging tool that focuses current into the formation. This resistivity information can be used like the ELOG resistivity information.

ELOG IND = Induction Electric Log. This log is an electromaqnetic resistivity tool. It induces current into the formation and measures the forniation resistivity. This resistivity can be used like the ELOG resistivity information.

GR-N = Gamma Ray Neutron Porosity. This probe is a stacked nuclear tool (it is two logging tools in one probe) that measures the natural gamma radiation from the rocks surrounding the borehole and also measures the neutron response to hydrogen from formation water. The information from the gamma radiation can be used for correlation from hole to hole and to locate clay. The information from the neutron measurement can be used to estimate the water content and the porosity of the formation.

Table 7. Explaination of geophysical logging measurements made in the U3ax/bl Waste Dispsal Unit drill holes (Table 6). 


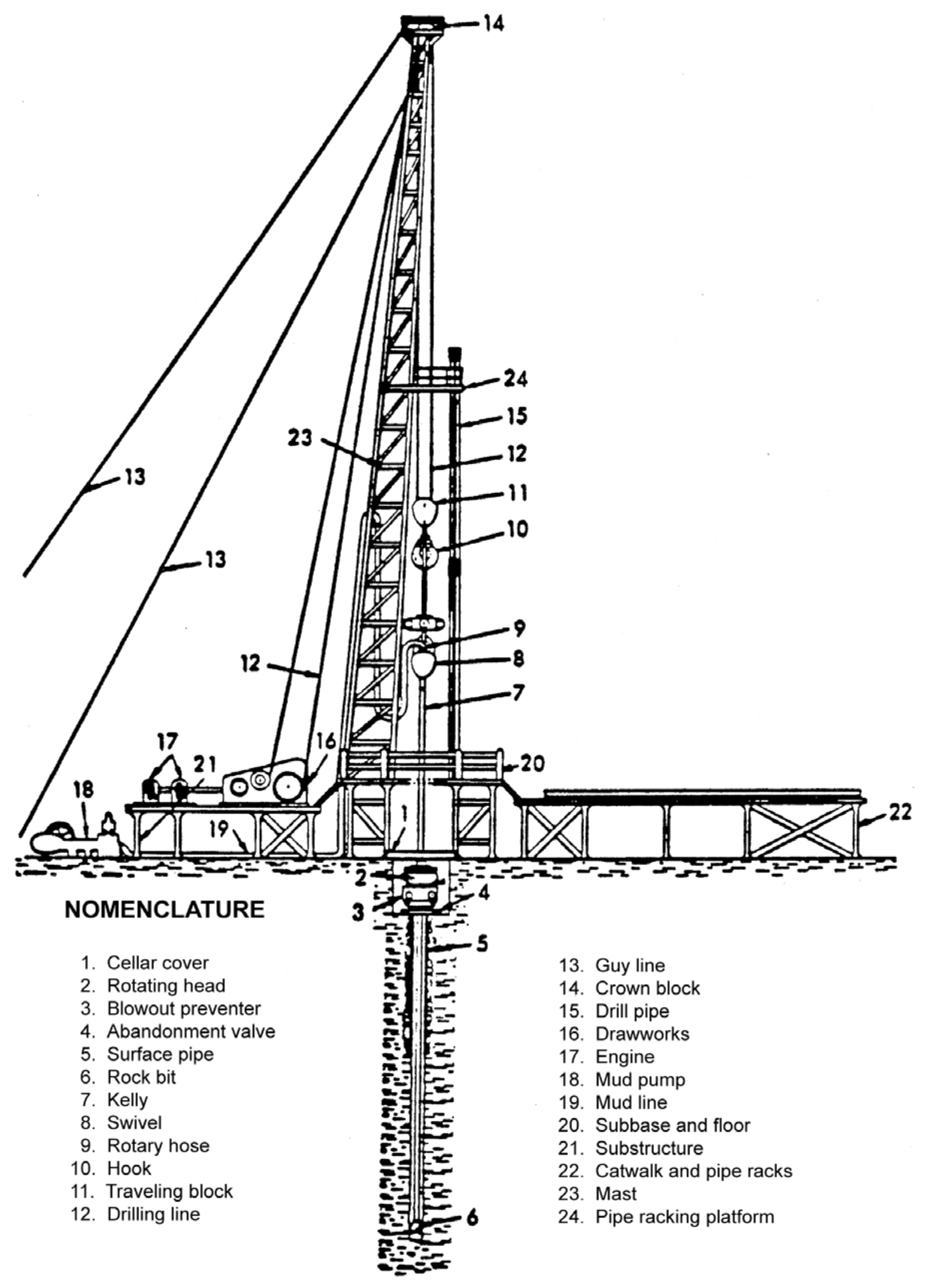

Figure 1. Standard Vertical Post-shot Drill Rig and Equipment (Butler, 1984) 


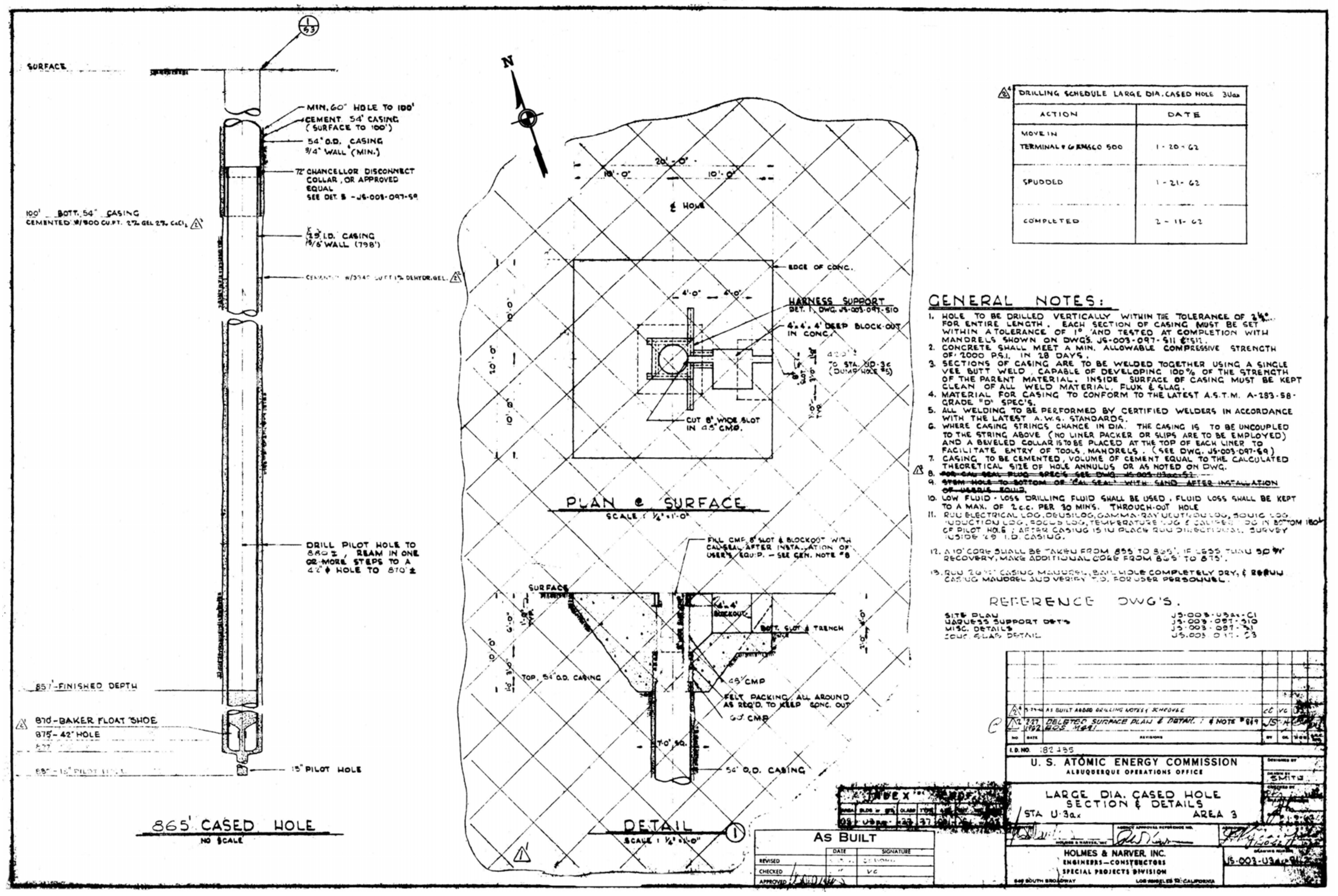

Figure 2. Drilling and Surface Construction Plan for U-3ax

(Drawing \# JS-003-U3ax-S1.2) 


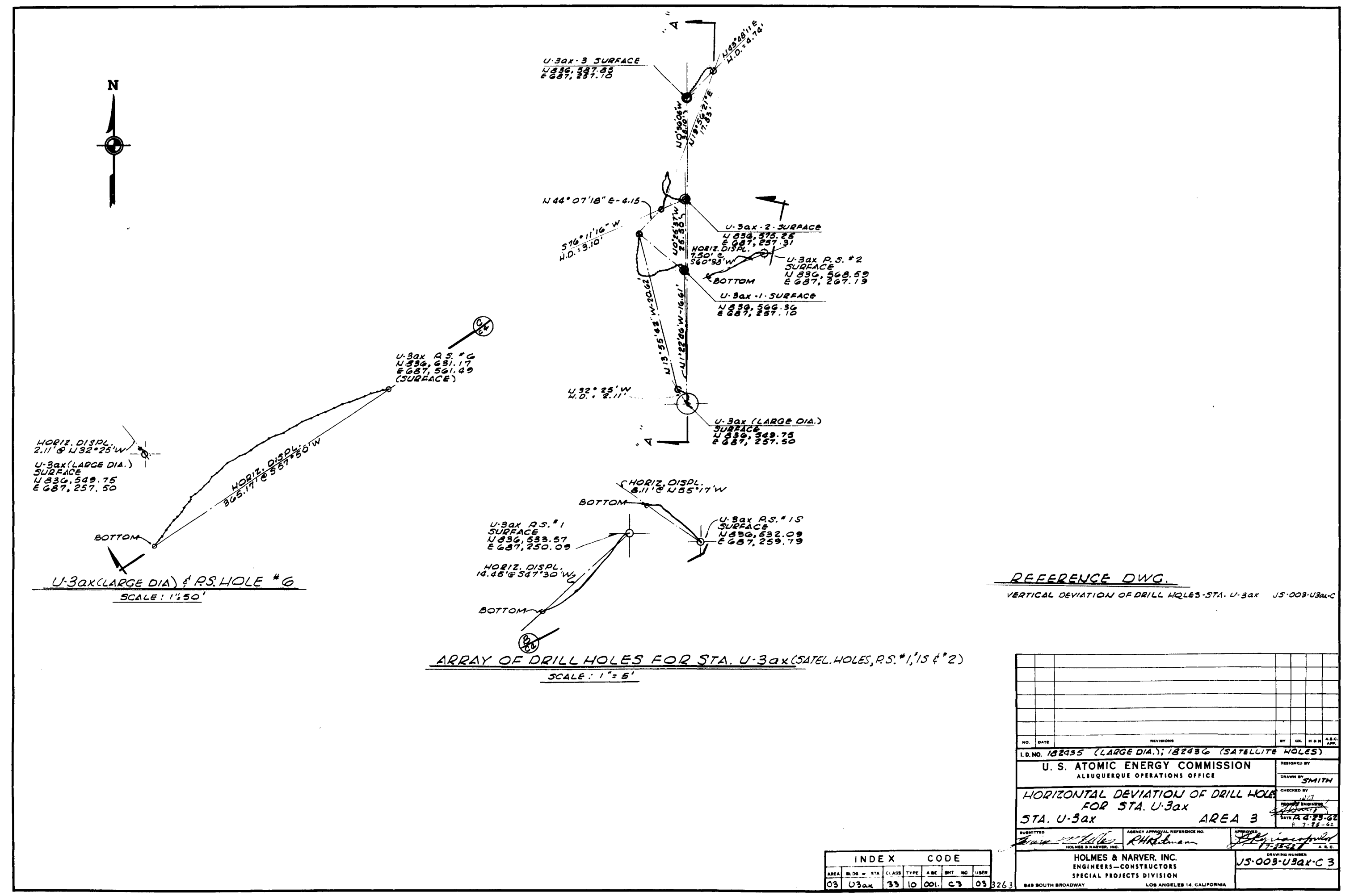

Figure 3. Surface and Subsurface Location of Holes for the

Event at U3ax

(Drawing \# JS-003-U3ax-C3) 


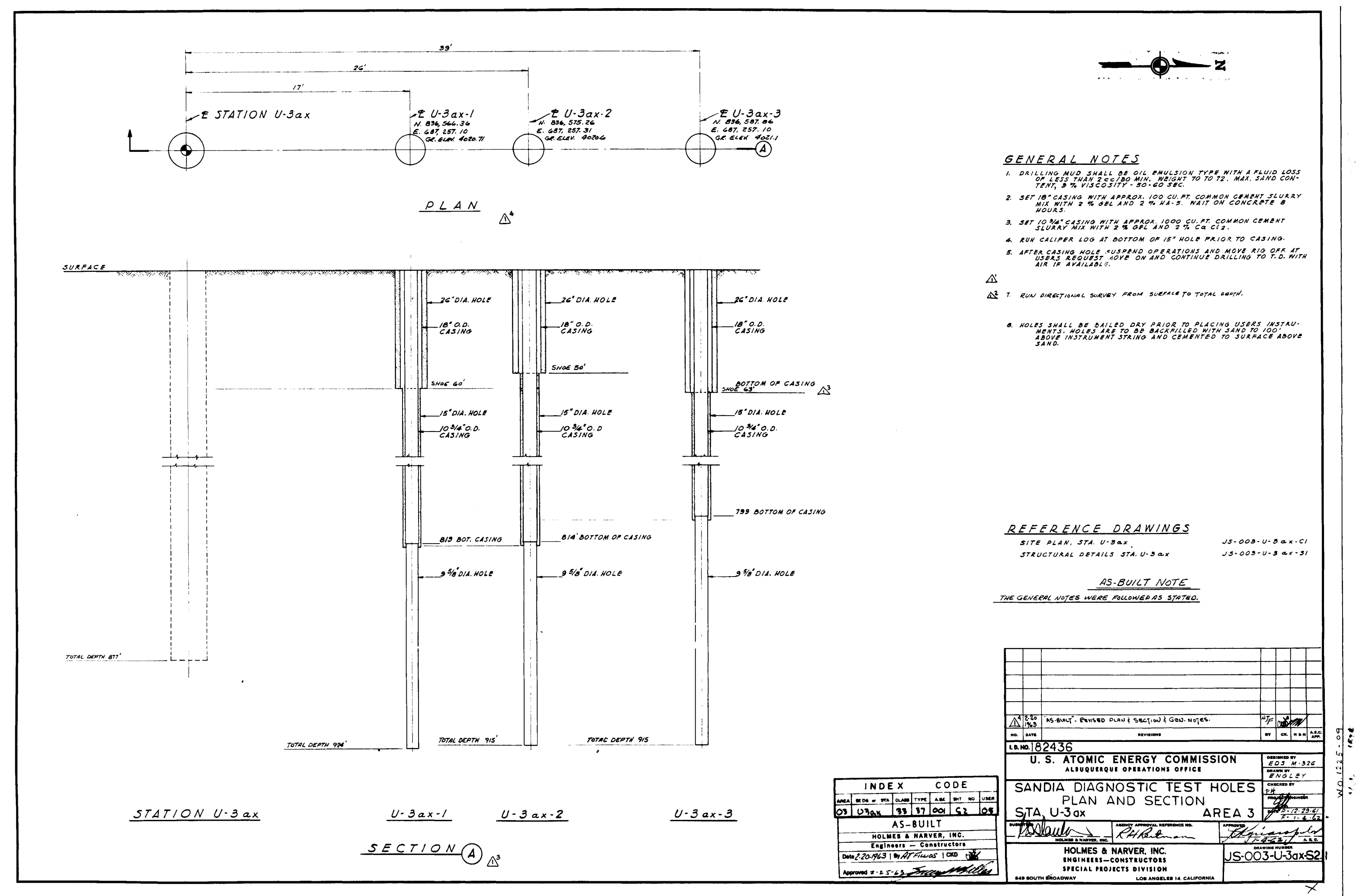

Figure 4. U3ax Satellite Holes (Drawing \# JS-003U-3ax-S2.1) 

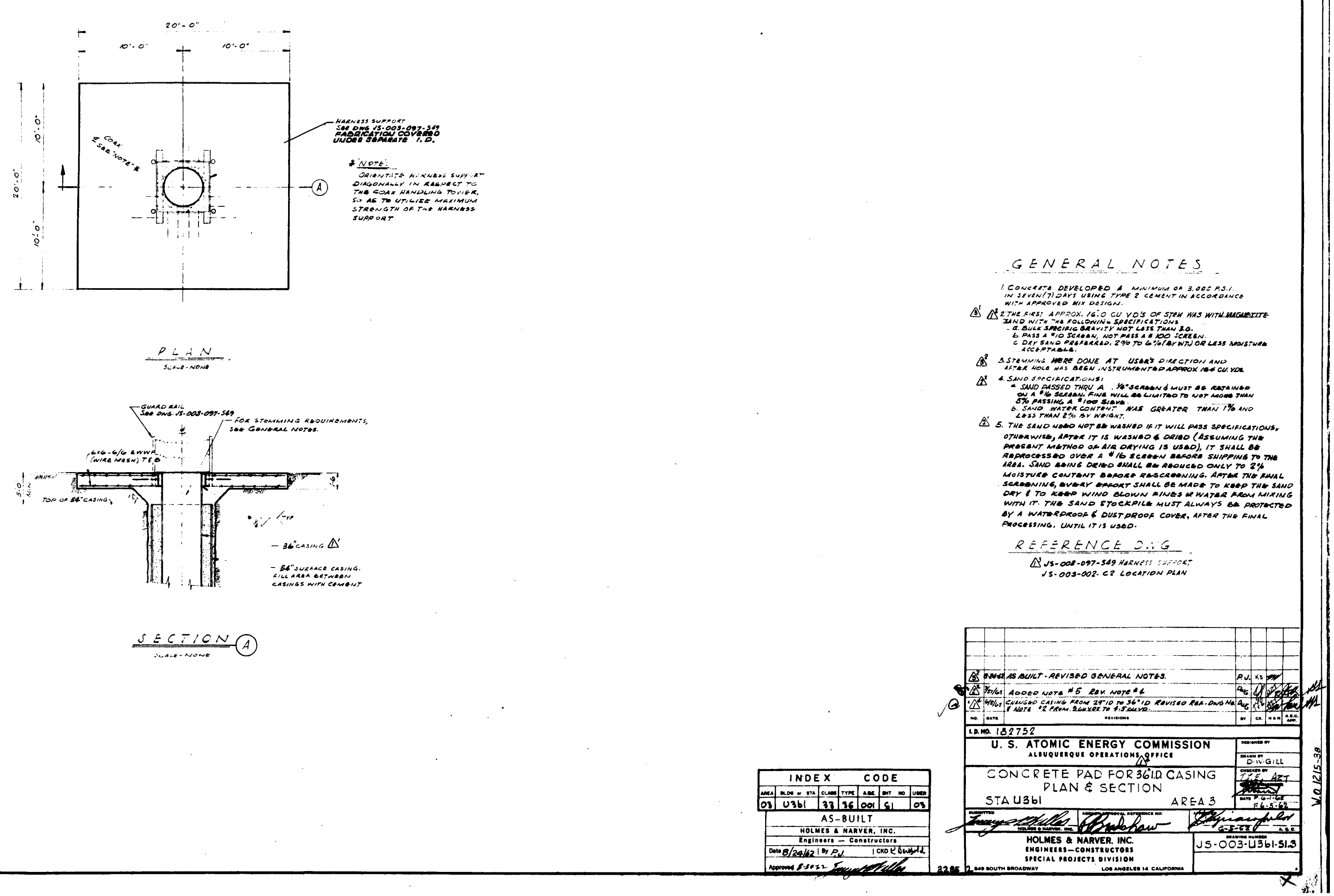

Figure 5. Surface Construction Plan for U-3bl

(Drawing \# JS-003-U3bl-S1.3) 


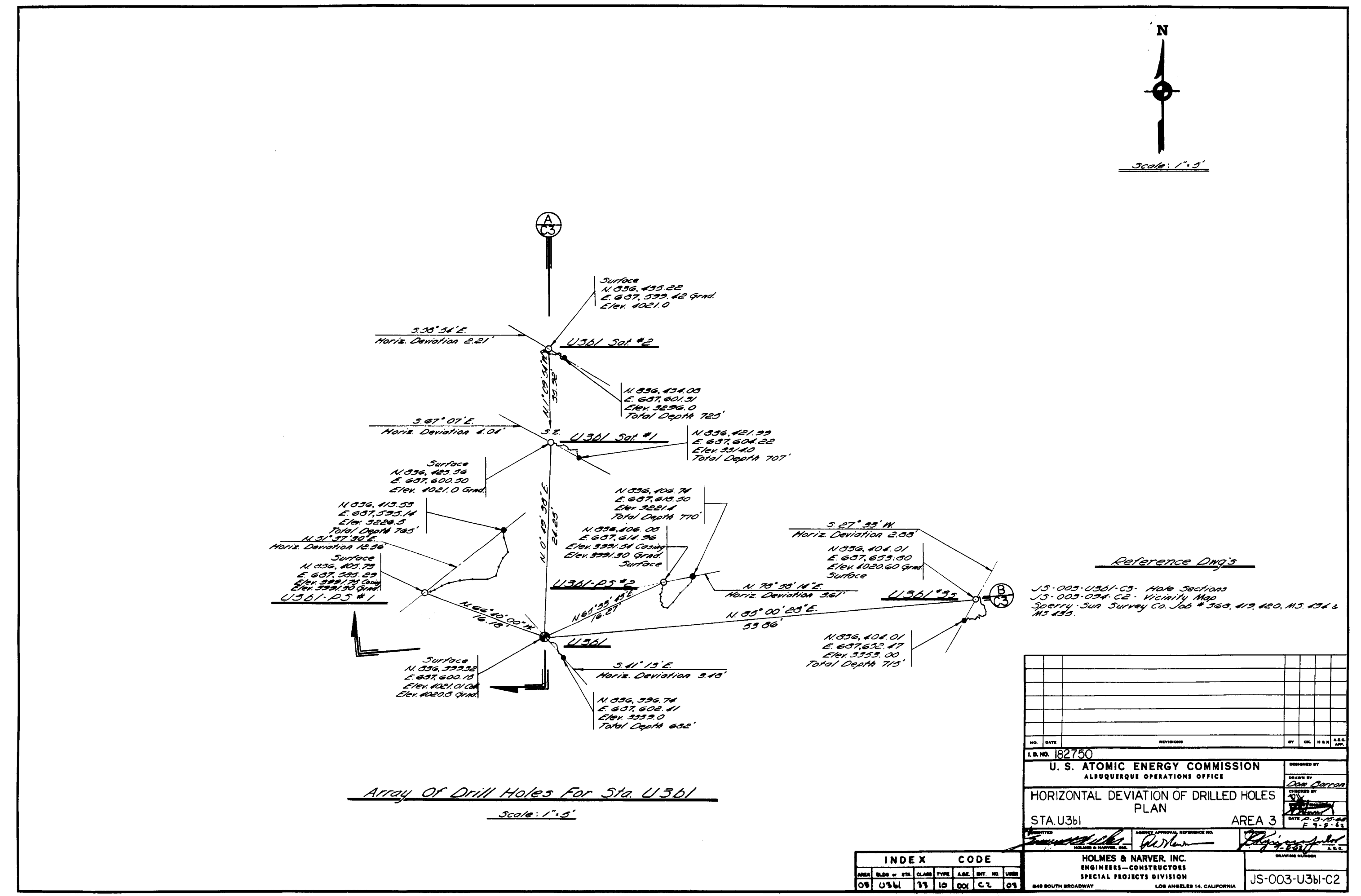




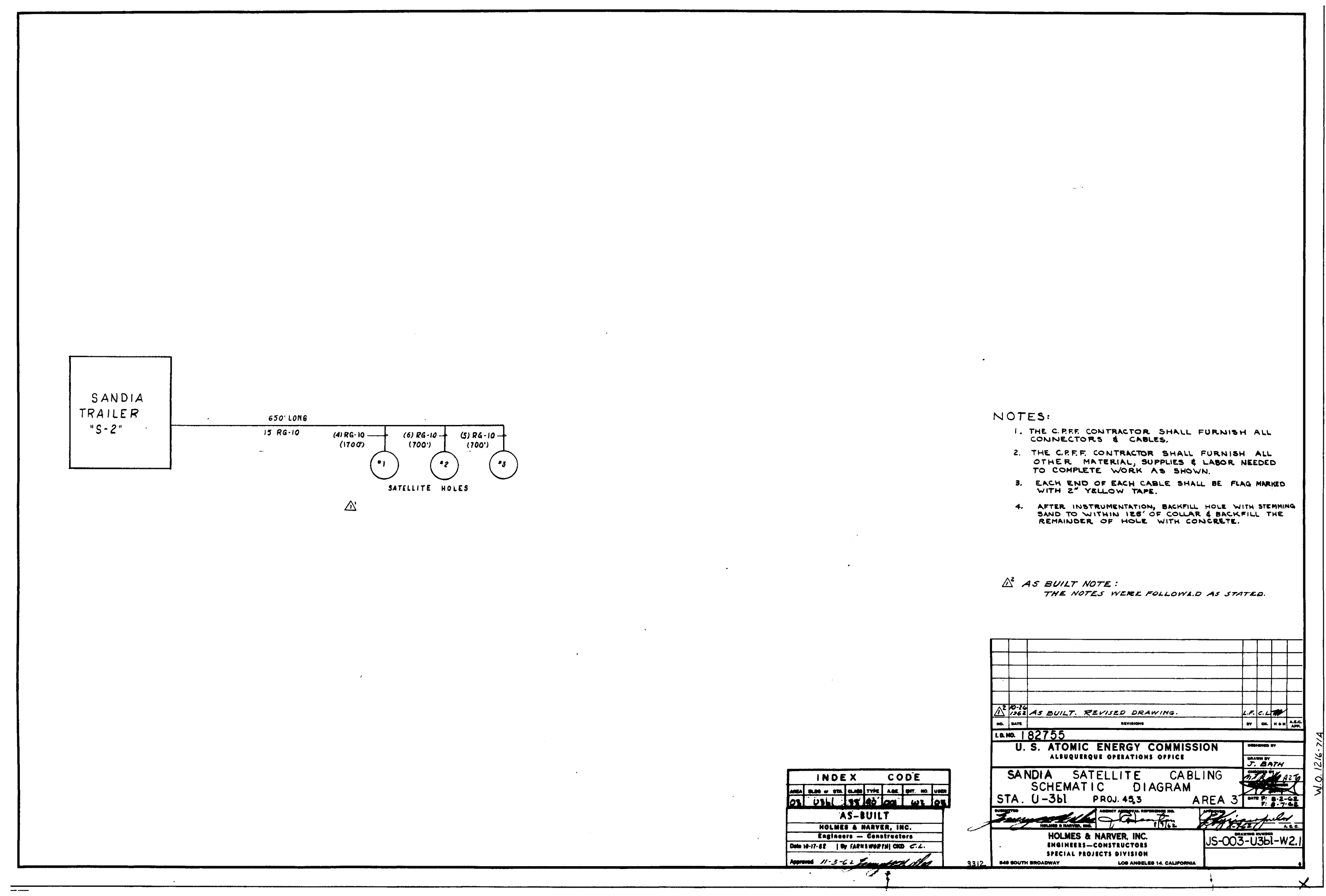




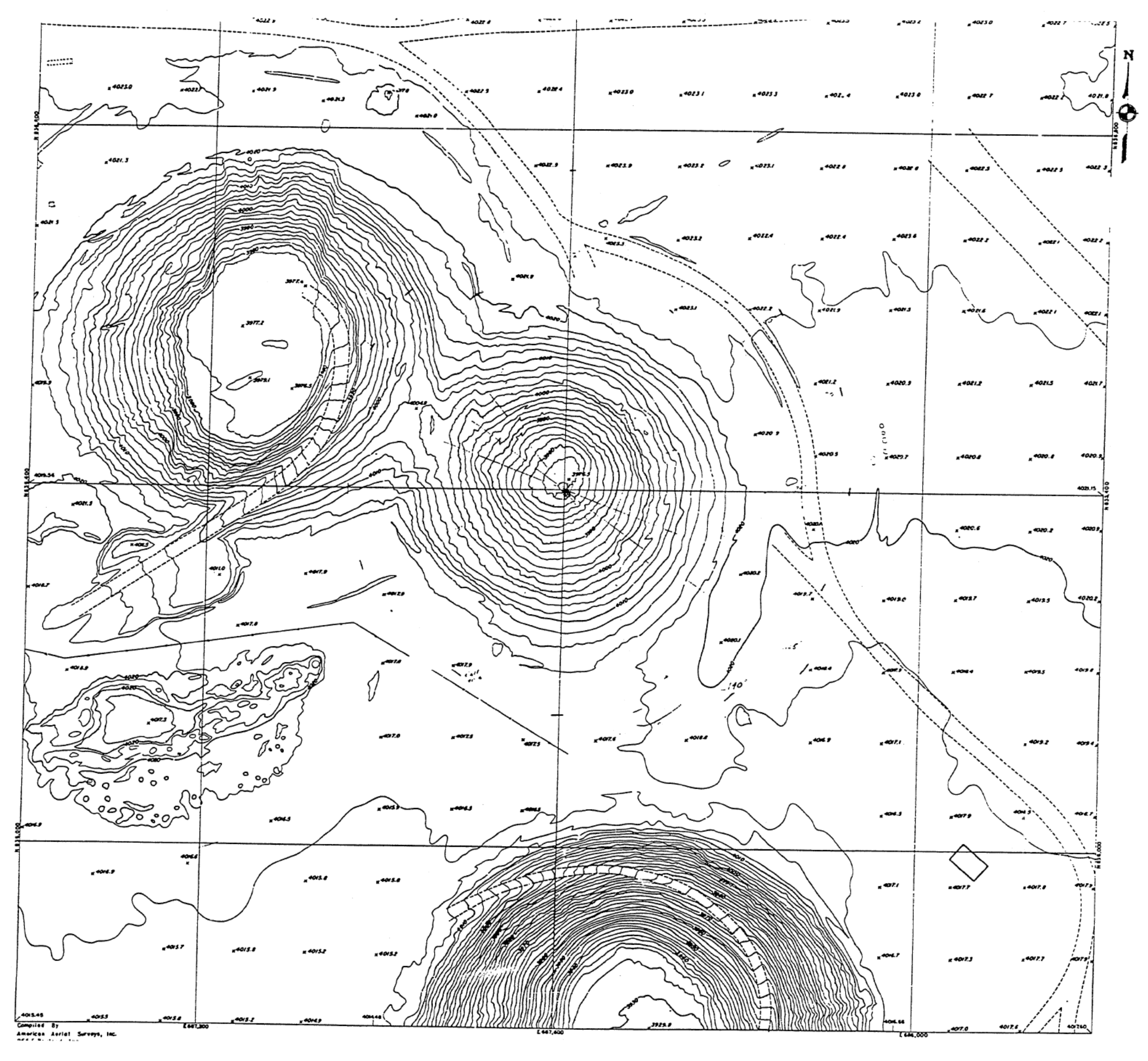

Figure 8. U3ax and U3bl Collapse Craters 


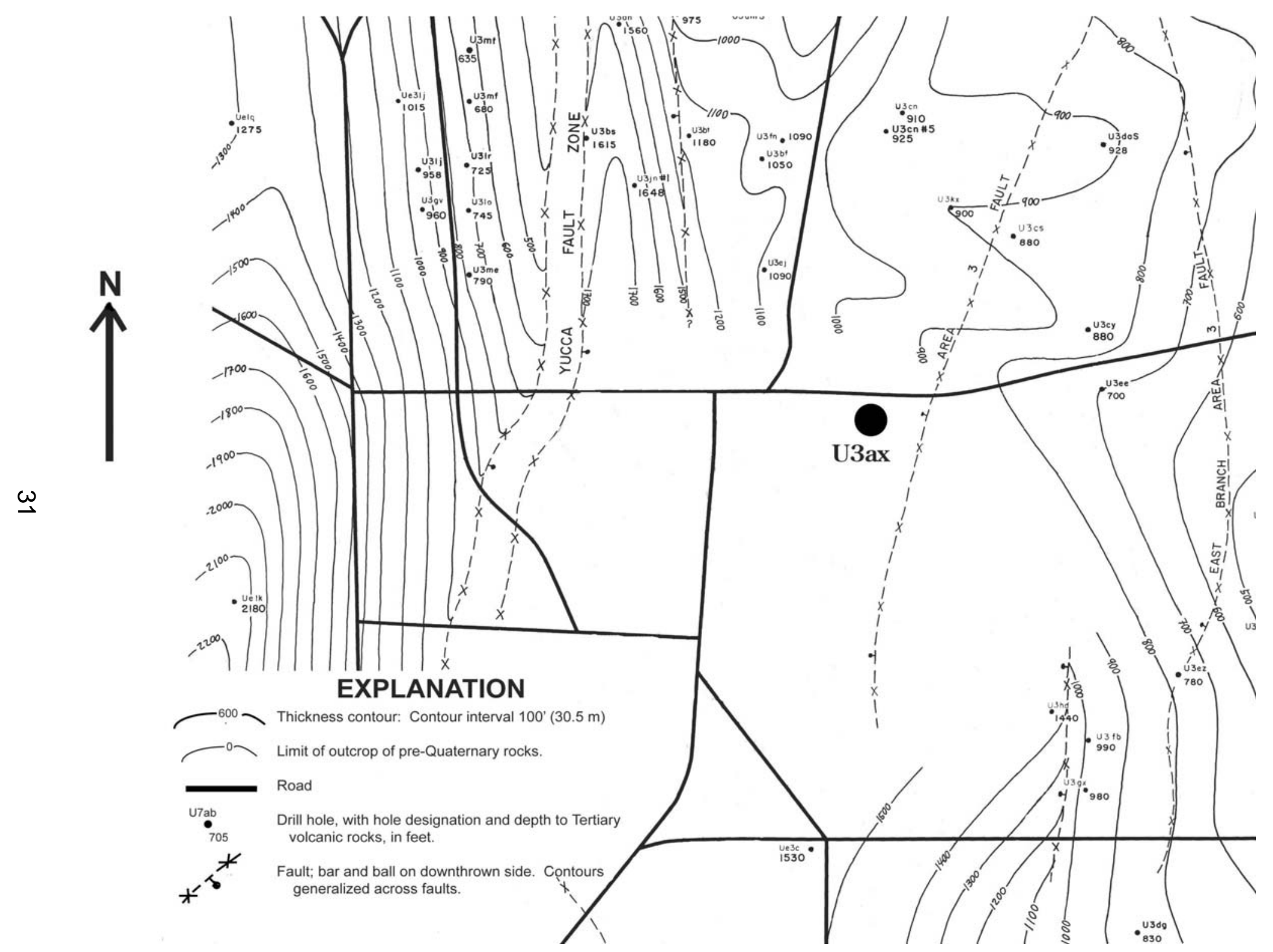

Figure 9. Alluvium Isopach Map for the Area 3 RWMS (Sig Drellack, 1988, Personal Communication) 
Appendix A

Hole Histories for RWMS Emplacement Holes
U-3ax
U-3bl
U-3ah
U-3at
U-3az
U-3bh
U-3bg 
HOLMES \& NARVER, INC.

WELL HISTORY DATA

HOLE NUMBER U-3ax

WORK ORDER NUMBER 1225 -08 H \& N I.D. NUMBER 182438

E.D.S. NUMBER M-483

USER LASL

TYPE HOLE_ Emplacement

LOCATION: Nevada (NTS)

County Nye

Area

3

Coordinates N836,550.01 . $.687,257,55$

Surface Elevation

4022. 4: Ground

RIG SCHEDULE: MOVED ON LOCATION $1-19-62$

SPUDDED. $1-20-62$

COMPLETED $2-13-62$

REMARKS:

USER ACCEPTANCE

$2-13-62$

MUD PROGRAM: LOW Fluid Loss of $3 \mathrm{cc} / 30 \mathrm{Min}$. Wt. 71, VISC 66 P.H. 8 San Content $3.5 \%$

(No record of total bbls. of mud used)

DRILLING EQUIPMENT. Term. \#6, Emsco 500.

\begin{tabular}{|c|c|c|c|c|c|c|c|c|c|}
\hline \multicolumn{3}{|c|}{ BORE HOLE RECORD } & \multicolumn{6}{|c|}{ CASING RECORD } & \multirow[b]{2}{*}{$\begin{array}{l}\text { SACKS } \\
\text { CEMEN I }\end{array}$} \\
\hline TOM & TO & SIZE & SIZE & WEIGHT & GRADE & COUPLING & FROM & TO & \\
\hline $0^{\prime}$ & $100^{\circ}$ & $60^{\prime \prime}$ & $54^{\prime \prime}$ & 352 & 33 & $B / W$ & $0^{\prime}$ & $100^{\prime}$ & $500 \mathrm{cu}$ \\
\hline $100^{\prime}$ & $875^{\prime}$ & $42^{\prime \prime}$ & $30^{\prime \prime}$ & 198 & 33 & $B / W$ & $72^{\prime}$ & $870^{\prime}$ & $3040^{\prime \prime}$ \\
\hline $875^{\prime}$ & $877^{\prime}$ & $15^{\prime \prime}$ & & & & & & & \\
\hline & & & & & & & & & \\
\hline & & & & & & & & & \\
\hline
\end{tabular}

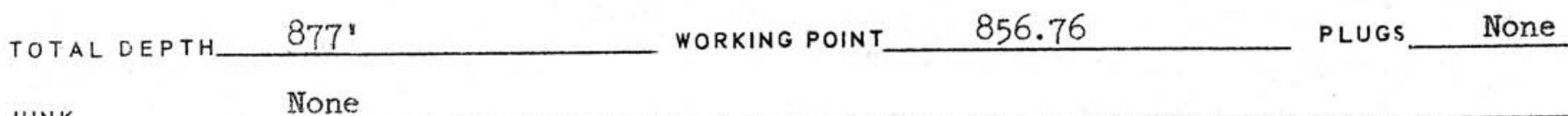

JUNK_ None

LOGGING DATA Lane Wells logs: Induction 600'-877', Focused -600'-877'. Electric 10g 600'-77'

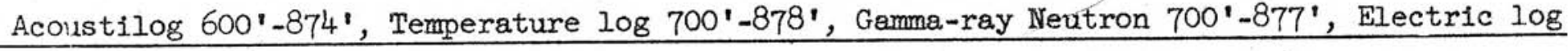
$680^{\prime}-881^{\prime}$. Sperry Sun directional survey ( $0^{\prime}$ to $\left.850^{\prime}\right)$.

DEVIATION DATA: M.D. $850^{\circ} \quad$ V.D._ R5EFERENCE SUR-138

BOtTOM HOLE COORDINATES N836,551.79 E687,256.42 (2.11'@N32²5'W)

CORING HISTORY Cored $855^{\prime}$ to $865^{\prime}$ with ne recovery. Cored $865^{\prime}$ to $875^{\prime}$, with $8^{\prime}$ recovery. 
Well History

$\mathrm{U}-32 \mathrm{x}$

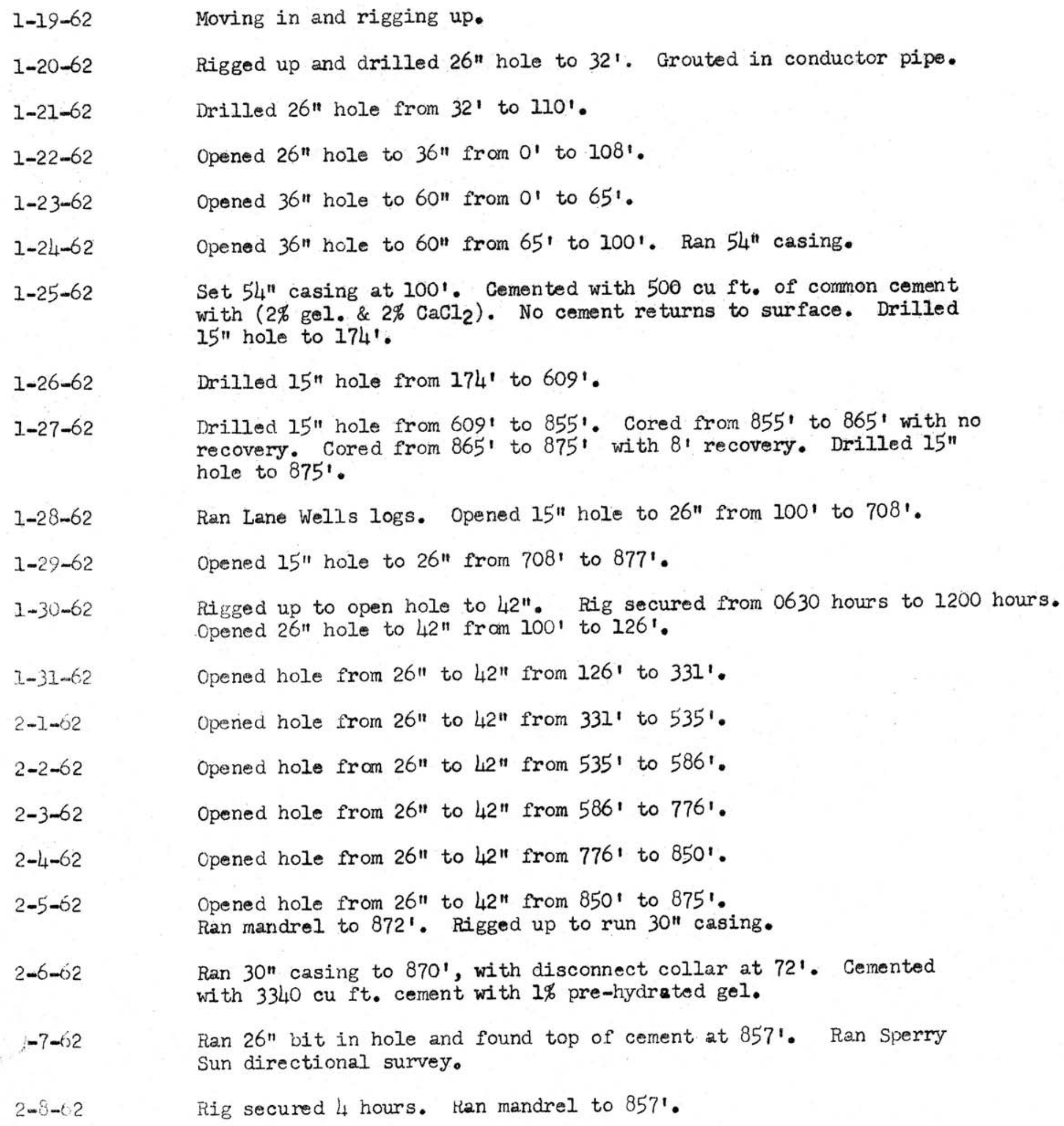


Well History

U-3ax 'cont'd'

$2-9-62$

$2-10-62$

$2-11-62$

$2-12-62$

$2-1.3-62$

Rig secured 7 hours. Ran pump and pumped hole dry.

Swabbed hole and ran mandrel to $857^{\prime}$.

Swabbed and bailed hole dry. Began tearing out rig.

Rigged down and cut conductor pipe.

Completed rigging down and hole completed. 
EMPLACEMENT HOLE

Coordinates: $\mathrm{N} \quad 836,5501 \frac{\mathrm{U}-3 \mathrm{ax}}{687,257, \mathrm{E}}$

Elev. 4022.4 Ground

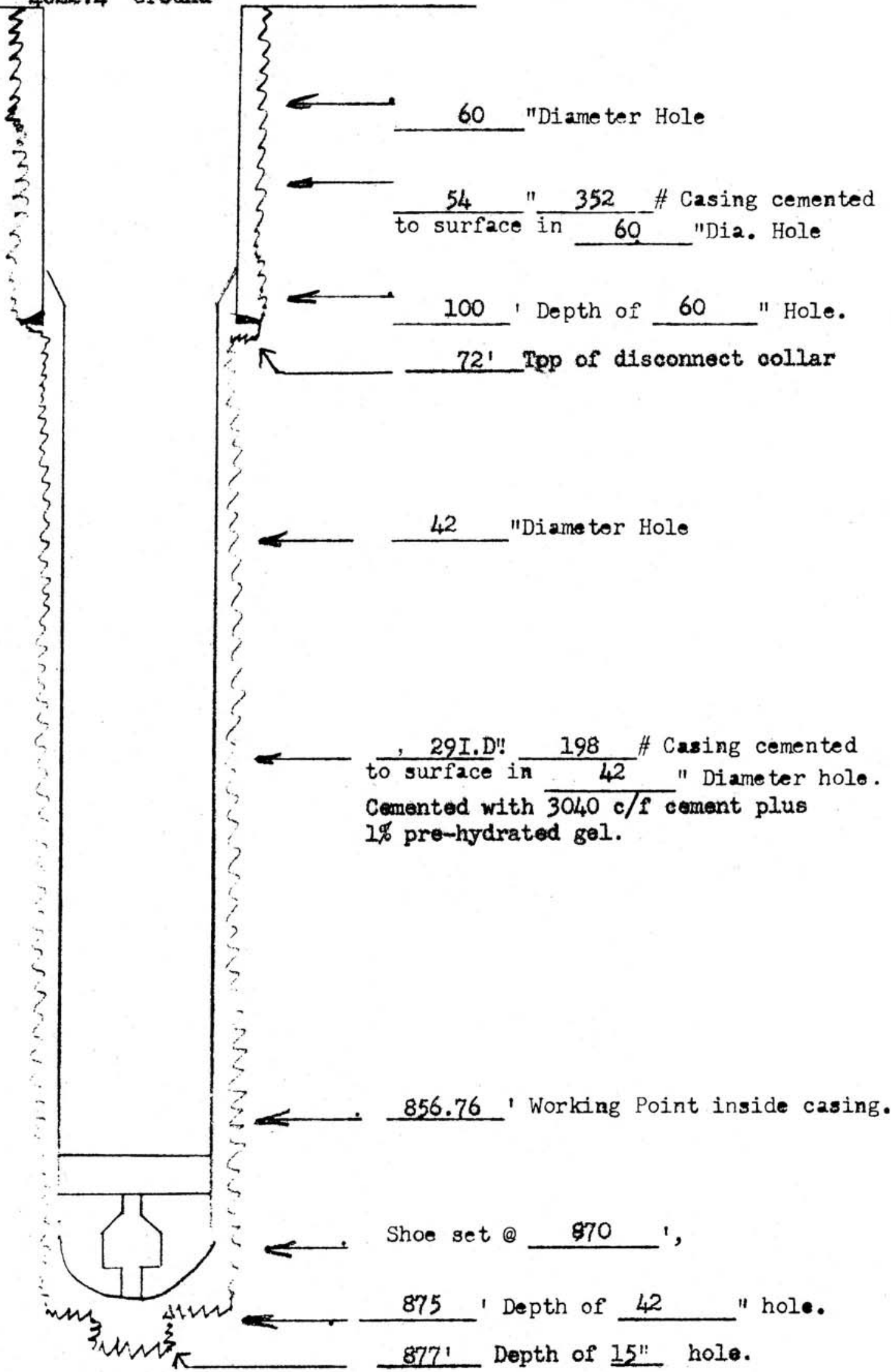




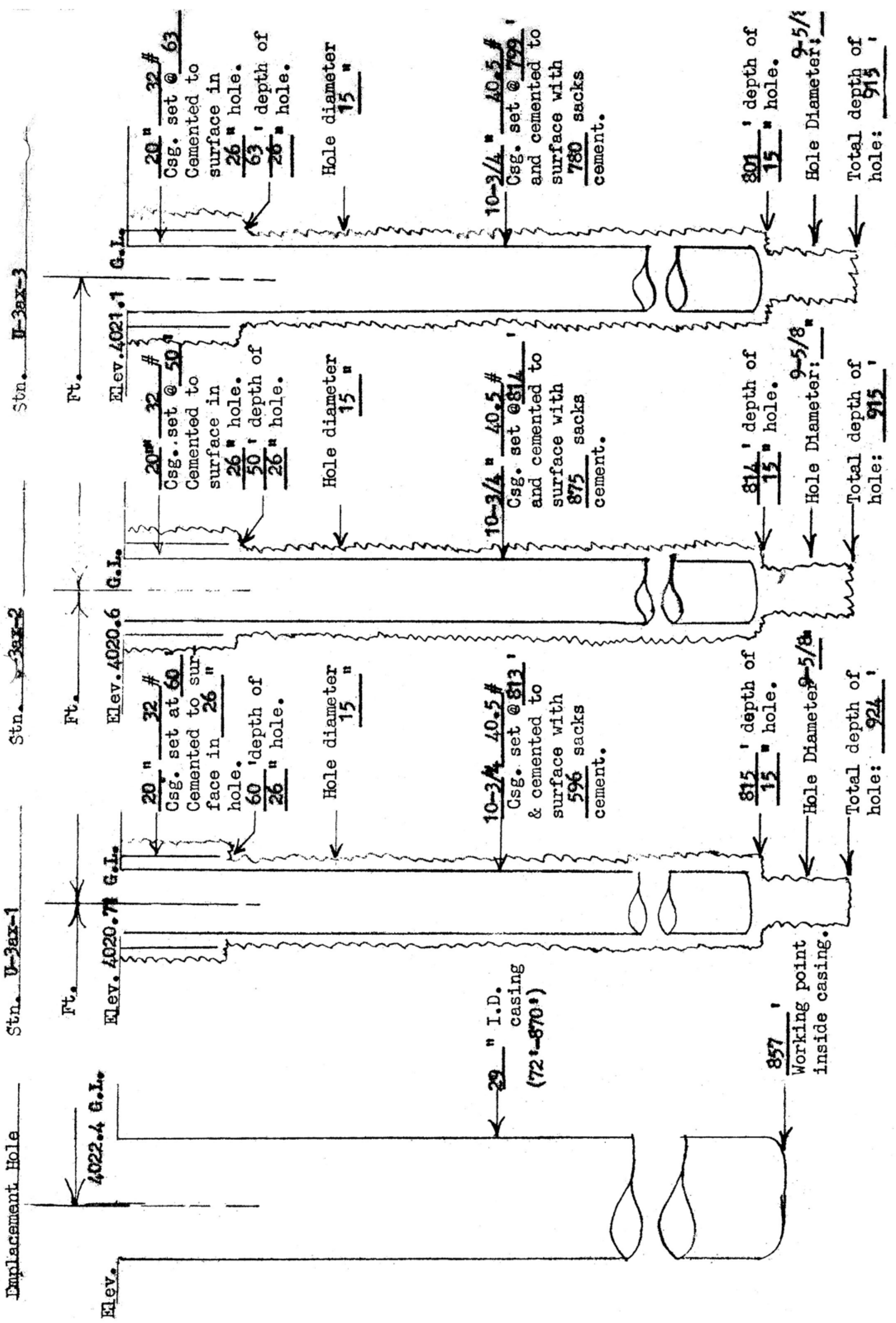




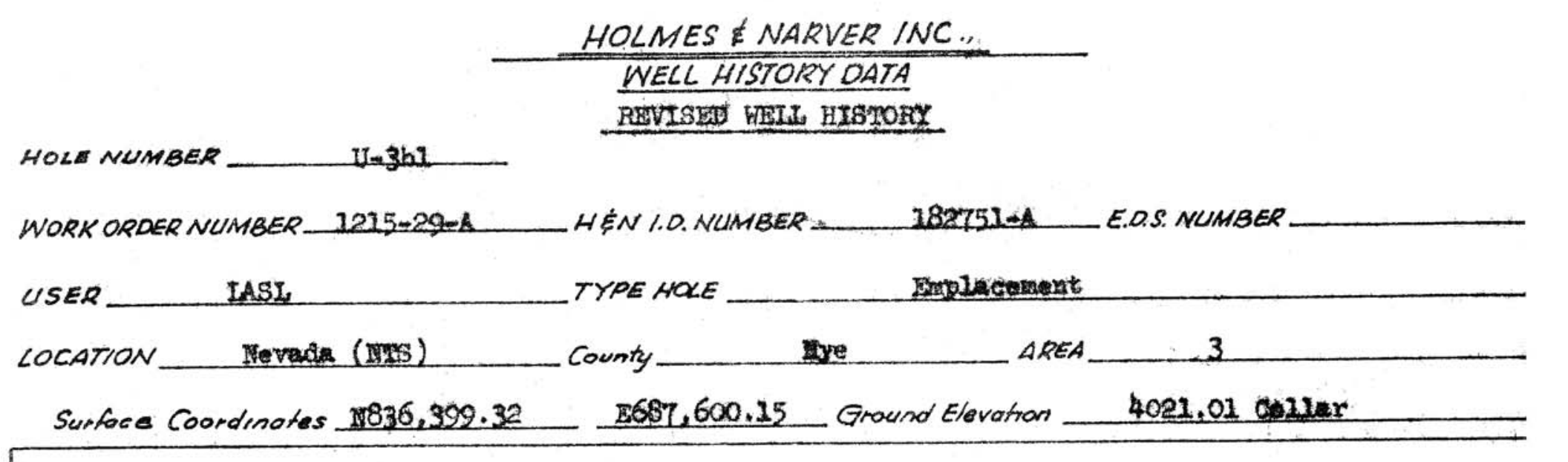
RIO SCHEDULE: MONEO ON LOCATION 6-10-62 SPUODEO 6-12-62 COMPLETEO 6 - 6-21-62

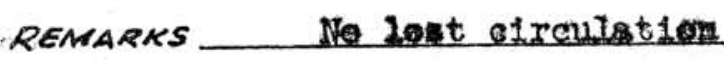

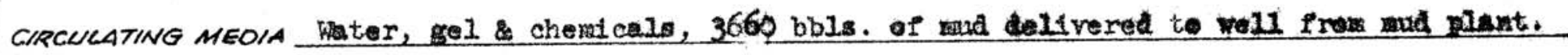
NO OF COMPRESSORS \& SIZE

ORILLING EQUIPMENT.

$\operatorname{cans00} 500$

\begin{tabular}{|c|c|c|c|c|c|c|c|c|c|c|}
\hline \multicolumn{3}{|c|}{ E HOLE RECORO } & \multicolumn{8}{|c|}{ CASING RECORD } \\
\hline FROM & 70 & s/ze & 1.0 & $w r / F x$ & WALS THICK. & GRADE & COUPLINO & FROM & ro & $\begin{array}{l}\text { CLIETEN } \\
\text { CEMENT }\end{array}$ \\
\hline$e^{\prime}$ & $20^{\circ}$ & $64^{\prime \prime}$ & 521 & $\operatorname{con}$ & wetor $D 1 D$ & & & $e^{\prime}$ & $20^{\prime}$ & 200 are. \\
\hline $0:$ & $690^{\prime}$ & $48 "$ & $36^{\prime \prime}$ & 294 & & $J-55$ & Bir & $0^{\prime}$ & 685 & 3800 orect \\
\hline $6900^{\prime}$ & 6931 & $36^{\prime \prime}$ & & & & & & & & \\
\hline & & & & & & & & & & \\
\hline & & & & & & & & & & \\
\hline
\end{tabular}

TOTAL DEPTH $693^{\prime}$ MANOREL OEPTH $682.70^{\circ}$ PLUGS Nare IUNK Hone

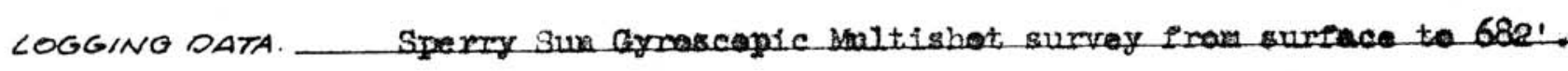

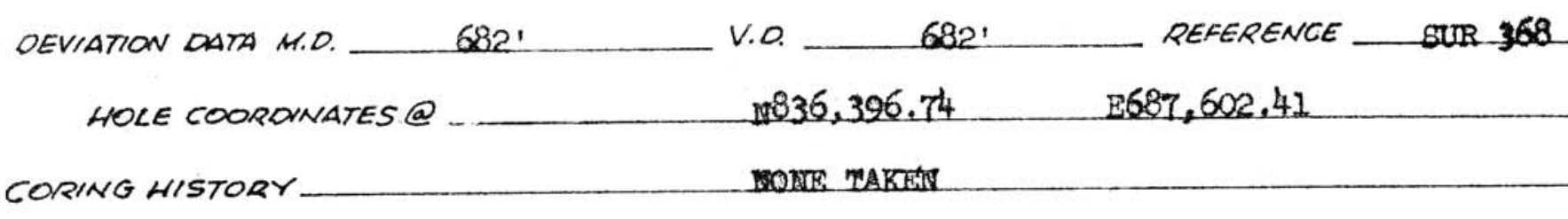

REVISION DATE M MarCh 9, 1963
WRITTEN BY


Well History

Stn. U-3bI

6-2-62 Bucket drill rig moved in and drilled $20^{\prime}$ of 64 " hole. Cemented one joint of $52^{\prime \prime}$ casing at 201 with 200 cu ft. of neat cement, cemented to surface.

6-10-62 Moved in Emsco 500 and started to rig up.

6-11-62 Rigged up.

6-12-62 Spudded in at 4:00 AM and drilled 15" hole to 695' using mud as a circulating media. Opened 15" hole to 26 " from $20^{\prime}$ to $96^{\prime}$.

6-13-62 opened 15" hole to $26 "$ from 961 to 611 '.

6-14-62 Opened 15' hole to $26 "$ from 611' to 695'. Opened 26" hole to 36" from 20 ' to $610^{\prime}$.

6-15-62 Opened 26" hole to $36 "$ from 610' to 693'. Opened 36 " hole to 48 " from $20^{\prime}$ to $428^{\prime}$.

6-16-62 Opened 36 "hole to 48 "from 428 ' to $647^{\prime}$.

6-17-62 Opened 36" hole to 48" from 647' to 690'. Conditioned mad to run casing.

6-18-62 Ran 36" casin'; to 685'.

6-19-62 Cemented $36 " \times 3 / 4 "$ wall casing at 635 ' thru $59 / 16 "$ drjil pipe, which was stabbed into Baker moat shoc, with $3600 \mathrm{cu}$ ft. of cement pre-rixed with 1 pre-hydrated gel. Full returns of cement at surface. Landed $36 "$ casing. "easured in with $26 "$ bit to 632.92 '. Measured in with $34^{1}$ " manurel checked top of cement at 682.611 . Had to roll off at $3^{51}, 501 \%$ 359'. Ran Sperry un Gyroscopic 'ultishot survey from surface to 6.32'.

6-20-62 Ban in with casing scraper and scrapped hole from surface to 693'. Bailed fluid out of hole.

6-21-62 Swabled hole dry and clean. Measured in with 34 mandrel to check working depth at 632.701 . Laid down drill pipe and started to tear out. Well comile ted. 


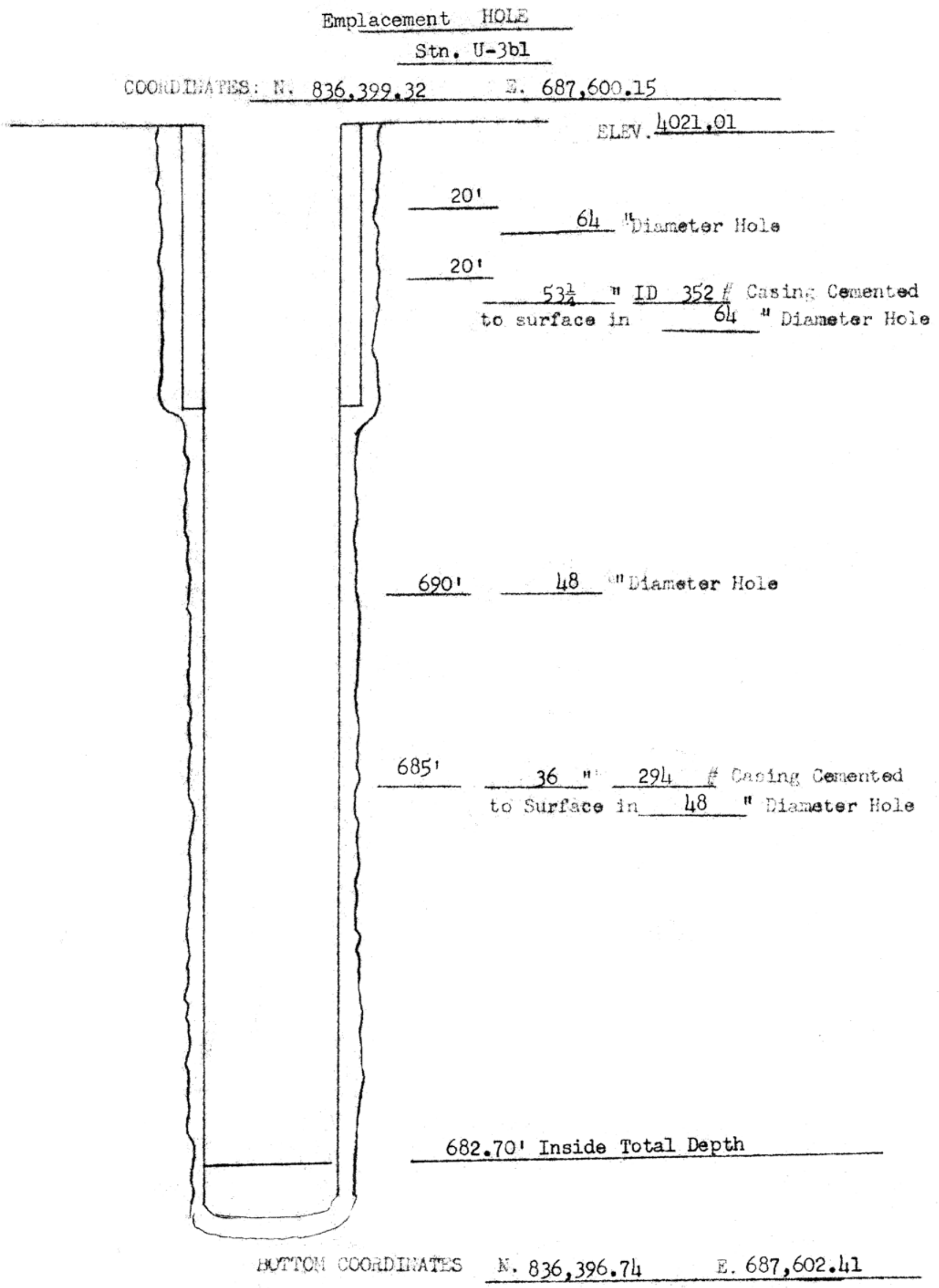


HOLMES \& NARVER, INC.

WELL HISTORY DATA

HOLE NUMBER U-3ah

WORK ORDER NUMBER $\quad 1210-12$

H\& N I.D. NUMBER 182350

E.D.S. NUMBER

$M-116$

USER IASL

TYPE HOLE, Large Diameter Cased Hole, Emplacement

LOCATION: Nevada

County

Nye

Coordinates N836,286.80' E686,481.05'

Surface Elevation 4020.24'

RIG SCHEDULE: MOVED ON.LOCATION_ 9-16-61

SPUDDED 9-17-6I

COMPLETED $\quad 11-22-61$

REMARKS:

USER ACCEPTANCE _ 11-22-61

MUD PROGRAM: Low Water Loss, OIl Emulsion Mud. Fluid Loss less than $2 \mathrm{cc} / 30$ mins.,

Sand contean less than $3 \%$.

DRILling equiPMENT. Terminal \#18, Ideco \#525.

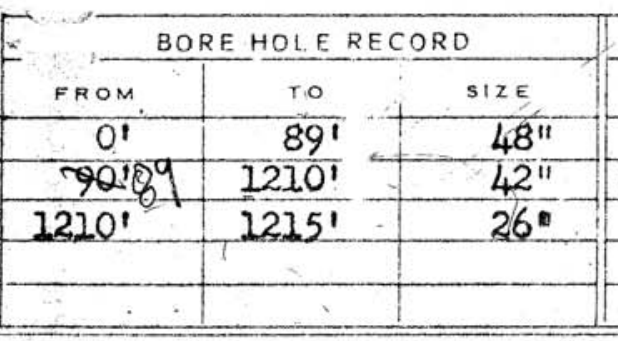

\begin{tabular}{|c|c|}
\hline & \\
\hline SIZE & WEIGHT \\
\hline $44^{\prime \prime}$ & $346 \#$ \\
\hline $3437^{11}$ & $294 \#$ \\
\hline $24^{\prime \prime}$ & $126 \#$ \\
\hline & \\
\hline & \\
\hline
\end{tabular}

$1211^{\prime}$

WORKING POINT

$1200^{\prime}$

PLUGS

TOTAL DEPTH

JUNK_ none

LOGGING DATA Schlumbargar $(10-8-61)$ Gamma Ray/Neutron $\left(90^{\prime}-1200^{\prime}\right)$, Sonic Log $\left(90^{\prime}=1200^{\prime}\right)$, Temperature Log $\left(90^{\prime}-1200^{\prime}\right)$, Electric $\log \left(90^{\prime}-1200^{\prime}\right)$, \& Sperry Sun Gyroscopic Survey $(11-13-61) 0^{\prime}-1200^{\prime}$.
DEVIATION DATA: M.D. $0^{\circ} 55^{\prime}$
V.D. $1200^{\prime}$
BOTTOM HOLE COORDINATES $1.54^{\prime} \mathrm{N} 39.5^{\circ} \mathrm{W}$. (from hole center)

REFERENCE

SUR No. 23

CORING HISTORY_COre\# I (12198'-1202'), Core\# $2\left(1202^{\prime}-1205^{\prime}\right)$, Recovered I'. 
WELI HISTORY

$\mathrm{U}-3 \mathrm{ah}$

9/16/61 Rig up (morning tour only).

9/17/61 Rig up

9/18/61 Spud. Drilled 26", $0^{\prime}$ to $50^{\prime}$.

9/19/61 Drilled 26" hole 50' to 102'. Opened 26" hole to 36" from $0^{\prime}$ to 93 '.

9/20/61 Opened 36" hole to 48" from $0^{\prime}$ to $89^{\prime}$.

9/21/6I Ran 44" O.D. casing to $70^{\prime}$ where it stopped. Pulled out and layed down casing.

9/22/61 Firished laying down 44" casing, reassembled table and re-reamed holo 0 'to 89 '

9/23/61 Re-ran 44" casing, Ran 101' of 44" O.D. B-W' casing, with shoe 90 ' below ground level. Cemented with 130 sacks cormon plus $130 \mathrm{cu}$. ft. Pozmix plus $3 \% \mathrm{CaCl}_{2}$. Cut off cond., weld F.L., Nipple up while W.O.C.

9/24/61 Cleand mud pits, welded up stabilizers. Ran in and found top of cement (3) 90'. Drilled 26" hole to 175'. 2 major crew accidents this day.

$9 / 25 / 61$ Drilled 26" hole, 115' to 237 '.

9/26/61 Drilled 26" hole, 237' to 317'.

9/27/61 Dr1lled 26" hole, 317' to 396'. 19/9/36/

9/28/61 Drilled 26" hole, 396' to 534'.

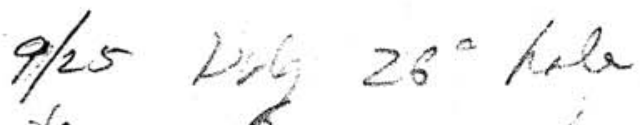

to $<$ to 260
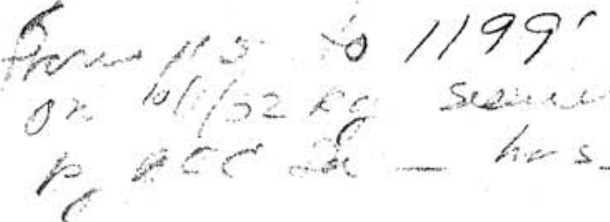

9/29/61 Drilled 26" hole, 534' to 605'.

9/30/61 Drilled 26" hole, 605' to 652'.

10/1/61 Drilled 26" hole, 652' to 675'. Secured by A.E.C. for 11 hours. Drilled 26" hole, 675' to 706 !.

10/2/61 Drilled 26" hole, $706^{\prime}$ to $810^{\prime}$.

10/3/61 Drilled 26" hole, 810' to 972 '.

10/4/61 Drilled 26" hole, 972 ' to 1014'.

10/5/61 Drilled 26" hole, 1014' to 1110'.

10/6/61 Drilled 26" hole, 1110 ' to 1164'.

10/7/61 Drilled 26" hole, 1164' to 1190'.

10/8/61 Drilled 26" hole, $11900^{\prime}$ to 1199'. Core No. 1, 1199' to 1202'. Cut 4', Recovery (not recorded). Rig to run Schlumberger logs. Ran Ganma RayNeutron, Sonic Temperature, and Electric logs. Ran Eastman directional survey. 
Well History U-3ah

Page 2

10/9/61 Load out Eastman, took core No. 2, $1202^{\prime}$ to $1205^{\prime}$, Cut 3', Recovered $2^{\prime}$. Drilled 26" hole 1205' to 1213'.

10/10/61 Drilled 26" hole 1213' to 1215'. ifis secured by AEC for 6 hours. Ream 26" hole to $42^{\prime \prime}$ from $90^{\prime}$ to $172^{\prime}$.

$10 / 11 / 61$ Reaming $26^{\prime \prime}$ to $42^{\prime \prime}$ from 172 ' to $453^{\prime}$.

$10 / 12 / 61$ Reaming $26^{\prime \prime}$ to $42^{\prime \prime}$ from $453^{\prime}$ to $493^{\prime}$.

$10 / 13 / 61$ Reaning $26^{\prime \prime}$ to $42^{\prime \prime}$ from 493 ' to 602 '.

$10 / 14 / 61$ Reaming $26^{\prime \prime}$ to $42^{\prime \prime}$ from $602^{\prime}$ to $714^{\prime}$.

10/15/62 Reaning $26^{\prime \prime}$ to $42^{\prime \prime}$ from $714^{\prime}$ to $947^{\prime}$.

10/16/61 Reaming 26" to $42 "$ from $947^{\prime}$ to $1035^{\prime}$.

$10 / 17 / 61$ Reaming $26^{\prime \prime}$ to $42^{\prime \prime}$ from $1035^{\prime}$ to $10 / 0^{\prime}$.

$10 / 18 / 61$ Raming $26 "$ to $42^{\prime \prime}$ from $1070^{\prime}$ to $1110^{\prime}$.

$10 / 19 / 61$ Reaming 26 " to $42^{\prime \prime}$ from $1110^{\prime}$ to 1172 '.

$10 / 20 / 61$ Reaming 26 ' to $42^{\prime \prime}$ from 1172 ' to $1210^{\prime}$.

10/21/61 Re-reamed 42" with 42" Grant reamer. Re-reamed from $90^{\prime}$ to 614'.

$10 / 22 / 61$ Re-roamed $6 y_{4}^{\prime}$ to $1210^{\prime}$.

10/23/61 Conditioned mud, slipped line and re-reamed 42 " hole to $1210^{\prime}$.

10/24/61 Re-ream hole and condition mud. Rig to run 36" I.D. casing. Run 36" I.D. casi

10/25/61 Ran 6 joints (280') of 36" I.D. $\times 3 / 4^{\prime \prime}$ wall B/W casing.

10/26/61 Ran 36" casing to 306'. Pipe stopped. Pulled 260,000 pounds, could not move. Ran drill pipe and poor boy swivel. Circulated to free pipe, could not move.

10/27/61 Pulling on 36" casing and breaking circulation once every hour. No racovery Rig to jack on casing.

10/28/61 Jacking on casing with 50 ton jacks and taking 200,000if pull. Circulated oil to try freeing casing, could not free. Rig to coment casing.

10/29/6I Cemented with $1224 \mathrm{cu}$. ft. of common cement with $2 \%$ dry gel and $2 \% \mathrm{CaCl}$. Drill pipe hung 303', no returns to the surface. W.O.C. Rig secured for 6 hours by AEC. Landed casing.

10/30/61 Rig for drilling. Jar on casing shoe. Run in with $26 "$ bit to drill out shoe. 
WELL HISTORY U-3ah (Cont.)

Page 3

10/31/61 Drilled out casing shoe. Ren to 1201 ' with $26^{\prime \prime}$ bit. No fill. Rereamed hole $306^{\prime}$ to $1210^{\prime}$.

11/1/61 Condition hole. Rig to run 24" casing, ran 8 joints (304.48')

11/2/6I Running 24" casing. Ran total 725.5 ' to date.

11/3/61 Running 24" casing on Chancellor disconnect collar. shoe at 1208 '.

11/4/61 Rig to run 2-7/8" tubing. Ran to 1204' where backed off.

$185^{\prime}$ fish in hole. Top of fish at 1.150'. Pulled 24." co.sing to floor and cut off disconnect collar. Recovered part of fish.

$11 / 5 / 61$ No record of activity.

11/6/61 Felt for shoe of 24 " casing. could not find. Rig to pull 24 " casing. Pulled 24" cesing and layed down in $80^{\prime}$ joints. Made bit, mun to 121.0' to condition hole. Repair casing shoe.

11/7/61 Rig to re-min 24" casing. Ran in 24 " casing to top of disconnect collar.

11/8/61 Ran 906', 5-9/16" drill pipe stinger. Ran 24" casing to 1208'. Top of disconnect collar at $283.72^{\prime}$. Rig to cement. Comented with 4500 as. ft. of conmon neat coment and $900 \mathrm{cu}$. ft. of pre-hydrated gel. Circulated from around disconnect, pulled 2-7/8" tubing out of hole. Cement in place (1) 12 noon.

$11 / 9 / 61$ W.0.C. for 10 hours. Disconnected Chancellor collar noon. Cleaned c cement out of $2.4 "$ casing ( 13 ' fill), $40^{\prime}$ of cement in drill pipo. Rig to $\min 27-1 / 2^{\prime \prime}$ bit.

$11 / 10 / 61$ Ran to 1743' (top of cement). Drilled conent with $17-1 / 2 "$ bit to 12001 . Reamod casing $2139^{\prime}$ to $1200^{\prime}$. Made 2 trips to condition mud.

11/11/61 Circulated and conditioned mud for 17 hours. Rig to mun B-J submersible pump.

$11 / 12 / 61$ Ren B-J pump to $1172^{\prime}$. Ran gump for 2 hours and stopped. Pulled pump, could not repair. Laid down 5-1/2" casing and pump. Rig to bail hole dry.

11/13/61 Ran Sperry Sun Directional Survey. Ran 21" mandrel, stopped at 312'. Roscraped 24" casing to $1200^{\prime}$. Clrculat hole clean. Rig to re-run mandrel.

11/24/61 Re-ran mandrel, stopped at 252'. Pulled and laid down mandrel. Rig to bail. Bailed to 400 '. "e-ran mandrel to 1200 't. Set screvs on lid of mandrel sheared dropping mandre to bottom. Top of fish 1149'. Make up fishing tools. Ran inside fish to 1198'. No recorery .

21/15/61 Spotted 200; of sand in figh. Hookod up Halliburton to fill hole. Ran in with drill pipe and cemented drill pipe in fish with $60 \mathrm{cu}$. ft. of Cal-Seal, W.O.C for two hours. Pulled out with fish. Rig to bail. Bailed hole to 1140 


\section{WELI HISTORY U-3ah (Cont.)}

Page 4

$11 / 16 / 61$ Bailed to $1770^{\prime}$. Rig to mun velocity surveys. U.E.D. velocity surreys for 12 hours. Bailed to 1200 '.

1]/17/61 Rigged swab. Swabbed hole dry. Ran cannister mandrel to 1182.' Rig to fill hole. Filled hole with raud, $\operatorname{ran} 17-1 / 2 "$ bit to $1171^{\prime}$.

11/18/61 Filling hole with mud. Drilled cement from 1182' to 1200'. Ream hole with 22-j/4" scraper from 1182' to $1200^{\prime}$. Rig to beil.

$11 / 19 / 61$ Bailing. Finished bailing to hole. Ren mandrel to 1200'. User accepted. Laying down drill pipe.

11/20/61 Swabbed hole dry. Started to rig out. User requested another cannister mun. Ran mandrel to $1200^{\prime}$. Pulled out laying down. Rigging out.

$11 / 21 / 61$ Tearing out. Hoving completed

$\mathrm{JSI} / \mathrm{hh}$ 
HOLMES \& NARVER, INC.

WELL HISTORY DATA

REVISED COVAR SHEET

HOLE NUMBER U-3at

WORK ORDER NUMBER_ 1211-19

H \& N I.D. NUMBER 182315

E.D.S. NUMBER M-171

USER_____ASI

TYPE HOLE

Emplacement

LOCATION:

Nevada(NTS) County

Nye

Area

3

JUNK

None

LOGGING DATA Sperry Sun Gyroscopic Multishot Survey 0-1000'

Lane Wells Surveys 0-1010' (Two runB), Gamm Ray/Neutran, Temperature, Induction, Acoustilog and Focused.

DEVIATICN DATA: M.D. 1000'

EOTTOM HOLE coordinates N N 835.792.26_E 686,830.40 (1.72@ N $58^{\circ} 48$ E)

CORING HISTORY

990 - $1000^{\prime}$ Rec. 8'

$855-865^{\prime}$ Rec. $6^{\prime}$ 
WELI HISTORY

U-3 at

1/9/62 Started move in and rig up. Terminal Rig \#18 (Ideco H-525)

1/10/62 Drilled 26" hole to 104'.

1/11/62 Drilled 26" hole to 104 - -123'. Opened 26" hole to 36" to 105'.

$1 / 12 / 62$ Opened $36 "$ hole to $60 "$ to 60 '.

$1 / 13 / 62$ Opened $36^{\prime \prime}$ hole to $60^{\prime \prime}$ to $96^{\prime}$.

$1 / 14 / 62$ Opened $36^{\prime \prime}$ hole to $96^{\prime \prime}$ to 100'. Ran 54" casing to $100^{\prime}$ and cemented with 500 sacks cement thru 5-9/16" drill pipe hung at 96'.

Cut off and landed casing.

1/15/62 Center punched 1.5" hole and drilled to $315^{\prime}$.

1/16/62 Drilled 15' hole 315' - 612'.

$1 / 17 / 62$ Drilled $15^{\prime \prime}$ hole 612' - 855'.

$1 / 18 / 62$ Rig secured 8 hours. Cored 855 - 865', recovered 6'.

Opened core hole to $15^{\prime \prime}$ and drilled $15^{\prime \prime}$ hole 865 - $880^{\prime}$.

1/19/62 Conditioned mud and ran following Lane Wells logs:

Gamma Ray/Neutron, Temperature, Acoustilog, Focus Log and Electrolog

from $100^{\prime}$ to $880^{\prime}$. Opened 15" hole to $26^{\prime \prime}$ from $100^{\prime}$ to $393^{\prime}$.

$1 / 20 / 62$ Opened $15^{\prime \prime}$ hole to $26^{\prime \prime}$ from $393^{\prime}$ to $692^{\prime}$.

$1 / 21 / 62$ Opened $15^{\prime \prime}$ hole to $26^{\prime \prime}$ from $692^{\prime}$ to $842^{\prime}$.

$1 / 22 / 62$ Opened $15^{\prime \prime}$ hole to $26^{\prime \prime}$ from $842^{\prime}$ to $880^{\prime}$.

Opened 26" hole to $42^{\prime \prime}$ from 100' to 119'.

$1 / 23 / 62$ Opened $26^{\prime \prime}$ hole to $42^{\prime \prime}$ from $119^{\prime}$ to $269^{\prime}$.

$1 / 24 / 62$ Opened 26" hole to $42^{\prime \prime}$ from $269^{\prime}$ to $324^{\prime}$.

Drilled 15" hole $880^{\prime}$ to 896'.

1/25/62 Drilled 15" hole 896' to 929'. On round trip to change bits bit feill (980' - junk on bottom?

1/26/62 Ran magnet to bottom - no recovery. Ran in with $15^{\prime \prime}$ bit, drilling on junk. Ran 10-5/8' bit and drilled on junk from 929' - 990'.

1/27/62 Ran in with core barrel. Made two dry runs due to fill.

1/28/62 Cored with 8" head 990' - 1000' recovered 8'. Opened core hole to $10-5 / 8^{\prime \prime}$ and drilled ahead from $1000^{\prime}$ to $1003^{\prime}$ on junk. Recovered small piece of iron fouled up in cones. Opened 10-5/8" hole to 15" from 929' to 1003'. Drilled 15" hole 1003 - 1015'. 
WELI HISTORY

U-3at - Pag e 3

1/29/62 Run following Lane Wells Logs: Gamma Ray/Neutron, Temperature, Induction, Acoustilog, and Focused from $800^{\prime}$ to $1015^{\prime}$. Opened $15^{\prime \prime}$ hole to $26^{\prime \prime}$ from $880^{\prime}-975^{\prime}$.

1/30/62 Opened 15" hole to $26^{\prime \prime}$ from 975 - 1015'.

$1 / 31 / 62$ Opened $26^{\prime \prime}$ hole to $42^{\prime \prime}$ from $324^{\prime}-484^{\prime}$.

2/1/62 Opened $26^{\prime \prime}$ hole to $42^{\prime \prime}$ from $484^{\prime}-603^{\prime}$.

$2 / 2 / 62$ Opened 26" hole to $42^{\prime \prime}$ from $603-680^{\prime}$.

2/3/62 Opened $26^{\prime \prime}$ hole to $42^{\prime \prime}$ from $680^{\prime}-769^{\prime}$.

2/4/62 Opend 26" hole to $42^{\prime \prime}$ from 769' to 84l'.

2/5/62 Opened 26" hole to 42 ' from $841^{\prime}$ to $909^{\prime}$.

2/6/62 Opened 26" hole to 42" from 909' to 1001'.

$2 / 7 / 62$ Opened $26^{\prime \prime}$ hole to $42^{\prime \prime}$ from 1001 ' to $1010^{\prime}$.

$2 / 8 / 62$ Conditioned mud to run casing.

2/9/62 Rig secured to 8 hours. Checked for fill, hole open ti 1010'. Started to run $29^{\prime \prime}$ casing.

2/10/62 Running Casing.

2/11/62 Cemented 29" I.D. casing with Baker float shoe (3 1005' with 4000 cubic feet cement with $1 \%$ prehydrated gel. Chancellor disconnect co.llar at 80.32'. Casing has $5 / 8^{\prime \prime}$ wall and weight 198\#/ft. Standing Cemented.

2/12/62 Bleed off pressure, pulled and laid down male end of disconnect collar. Ran in with 26" bit and located top of cement at 1000'. Ran 26-1/2" x 50' mandrel to check w.p. of 1000'. Rigged up B-J pump and started to pump out casing.

2/13/62 Pump blew up - finished removing fluid with bailer. Ran Sperry Sun Gyroscopic Multichsot survey of entire hole.

2/14/62 Swabbed hole dry. Ran 26-1/2" mandrel and checked working point (3) 999.74. Witnessed and epproved by Holmes and Narver.

2/15/62 Land casing. Rig down. Well completed 2/15/62. 
HOLMES \& NARVER, INC.

WELL HISTORY DATA

REVISED COVER SHEET

HOLE NUMBER U-3az

WORK ORDER NUMBER_1225-16

H\&N I.D. NUMBER 182440

E.D.S. NUMBER $M-324$

USER LASL

TYPE HOLE

Emplacement

LOCATION: Nevada (NTS) County Aro Nye 3

Coordinates $\mathrm{N} 835,802.90 \quad$ E $687,693.17$ Surface Elevation 4016.00

RIG SCHEDUle: MOVED ON LOCATION 2-16-62 SPUDded 2-17-62 COMPLETED 3-8-62

REMARKS:

USER ACCEPTANCE

MUD PROGRAM:

011 emulsion (specifications were for max. $2 c c / 30 \mathrm{~min}$. F.L. and less than

$3 \%$ sand content, wt. 70 to 72 , viscos 1 ty $50-60$ sec. Total bbl used 315

(report incomplete)

DRILLING EQUIPMENT. Terminal \#18, Ideco \#525

\begin{tabular}{|c|c|c|c|c|c|c|c|c|c|}
\hline \multicolumn{3}{|c|}{ BORE HOLE RECORD } & \multicolumn{6}{|c|}{ CASING RECORD } & \multirow[b]{2}{*}{$\begin{array}{l}\text { S.ACKS } \\
\text { CEMENT }\end{array}$} \\
\hline FROM & To & SIZE & $S: Z E$ & WEIGHT & GRADE & COUPLING & FROM & TO & \\
\hline $0^{\prime}$ & $100^{\prime}$ & $60^{\prime \prime}$ & $54 "$ & 352 & 33 & $B / W$ & 10 & 98 & 500 \\
\hline $100^{\prime}$ & $875^{\prime}$ & $42^{\prime \prime}$ & $29^{\prime \prime}$ & 198 & 33 & B/W & 0 & 870 & 5550 \\
\hline $875^{\prime}$ & $882^{\prime}$ & $15^{\prime \prime}$ & & & & & & & \\
\hline & & & & & & & & & \\
\hline & & & & & & & & & \\
\hline
\end{tabular}

TOTAL DEPTH_ $882^{\prime}$ WORKING POINT__ $866^{\circ}$ PLUGS 866 to $882^{\prime}$

JUNK_ None

LOGGING DATA

Acoust1log $\left(680^{\prime}-87^{\prime}\right)$, Focused $\log \left(680-870^{\prime}\right)$, Gamm Ray/Neutron(680'-881')

Densilog ( $\left.6801881^{\prime}\right)$, Induction Electr1log (680'-882'), Temperature to

867', Sperry Sun D1rectional survey, $0^{\prime}-865^{\prime}$.

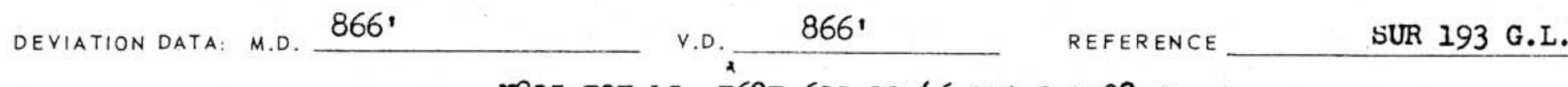

BOtTOM HOLE COORDINATES N835,797.15 E687,695.20 (6.32'@ S18028' E)

CORING HISTORY__ (855 to 865$)$ Rec. $7^{\prime}$. 


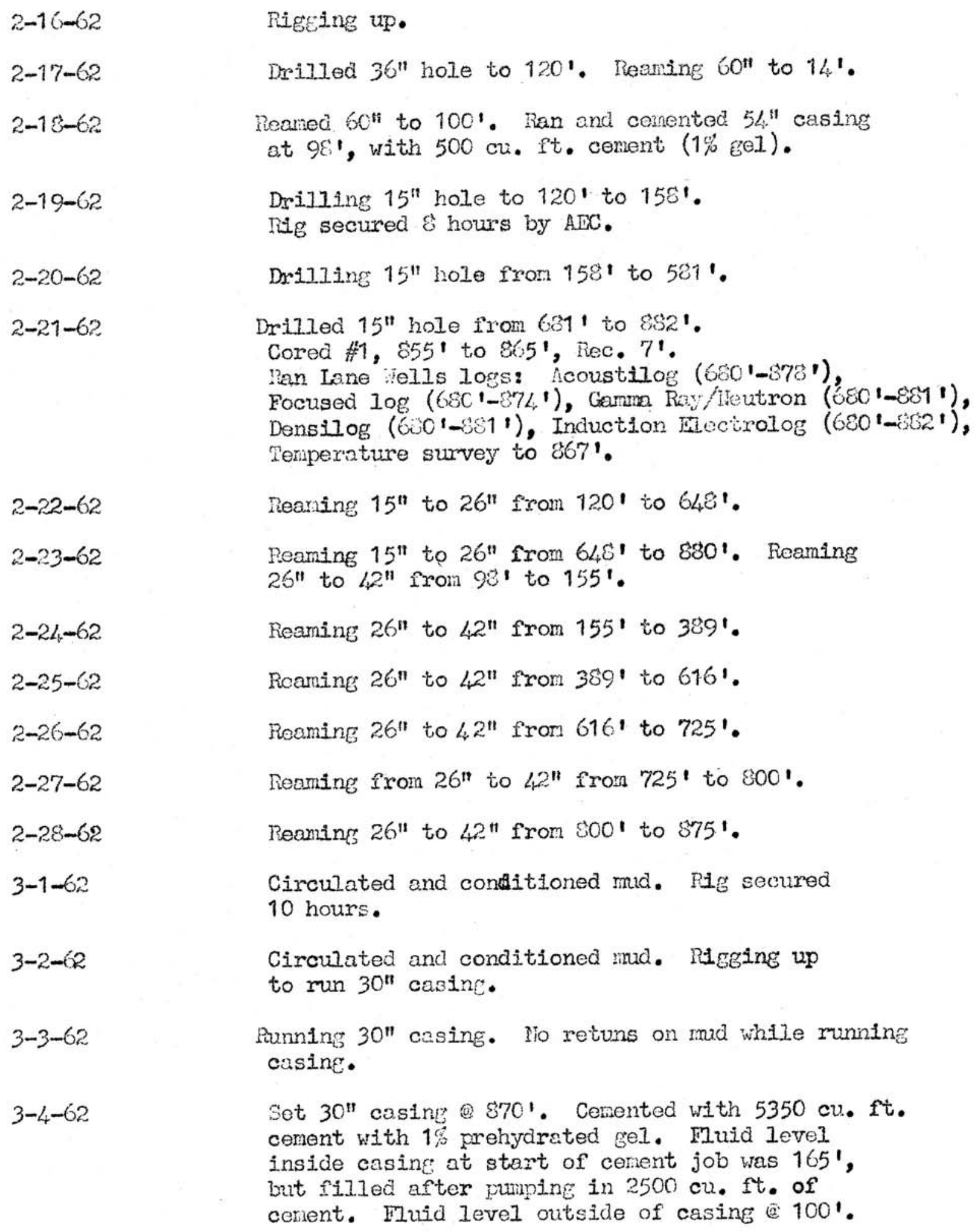


Ran temperature Iog. (Top of cement outside $30^{\prime \prime}$ crsing@5301). Cercented with $200 \mathrm{cu}$. ît. down tubing outeide of $3 C^{\prime \prime}$ casing and ran temperature 108 (Top of cenent (0) 255').

Pan 26" bit and found bottom (2) 869.02'. Plug: back with $18 \mathrm{cu}$. ft. of $\mathrm{Col}-30 \mathrm{al}$. to 3651 '. Rigged up to run Sperry Sun.

Ian Sperry Sun 10g. Ran mandrel to 866 . Ron purnp and puiped well dry . Bailed and mopred fluid out of hole.

Finished drying hole. Pan mandrel to 866'. Laying down dritl pipe and preparing to move rig. 
HuL

NUMBER U-30h

WORK OROER NUMBER 1215-40

HEN 1.0. NUMBER

182760

E.D.S. NUMBER

USER

IASI

TYPE HOE

Molacement

LOCATION

Nevada (NIS)

County

Iye $A R E A$

3

Surface Coordinates $1835,600.24$

1688,400.65 Ground Elovation

4016.9

RIO SCHEOULE: HOVEO ON LOCATION 6-16-62 SPUONEO_ 6-16-62 COMPLETEO 7-21-62

REMARKS No rig on job $7-5-62$ and iram 7-7-62 thm 7-9-62

CIRCULATING MEOIA Air

NO OF COHPRESSORS \& SILE

ORILLING EQUIPMENT DilWell 860 to point of Partial Cnt'g. ammulus of $22^{\prime \prime}$. Portadrill

National I-20, Ideco $\mathrm{H}-35$ and Failing 500 at various stages to cenent por con

\begin{tabular}{|c|c|c|c|c|c|c|c|c|c|c|}
\hline \multicolumn{3}{|c|}{ AORE HOLE RECORO } & \multicolumn{8}{|c|}{ CASING RECORD } \\
\hline s & ro & $S / z E$ & 1.0. & WT/FT. & WALL PHIGK. & GRAOE & COUPLING & EROM & ro & $\begin{array}{l}\text { CUIET } \\
\text { CEMENT }\end{array}$ \\
\hline $0^{\prime}$ & $80^{\prime}$ & 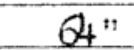 & $42^{11}$ & 354 & & & $B / W$ & $0^{\prime}$ & $80^{\prime}$ & $472 \mathrm{cu} . \mathrm{It}$ \\
\hline $80^{\circ}$ & $939^{\circ}$ & $42^{\prime \prime}$ & $29^{13}$ & 198 & & $J-55$ & $B / W$ & $0^{\prime}$ & $870^{\circ}$ & 23100 cu. 20 \\
\hline $939^{\prime}$ & $1080^{\prime}$ & $26^{\prime \prime}$ & & & & & & & & \\
\hline & & & & & & & & & & \\
\hline 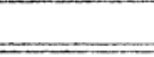 & 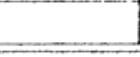 & + & & & 6 & -1 & & & & \\
\hline
\end{tabular}

TOTAL DEPTH

$1080^{\prime}$

MANOREL DEPTH

$717.92:$

PLUGS Eartien Plug 939'-1080' open hole 870'-939'

IUNK

Hone

cenent in $29^{\prime \prime} 870^{\circ}-718^{\prime}$

LOGGING DATA. S. Sperry Sun Gyroscopie Multishot Directionel Eurvey from $0^{\prime}$ to $865^{\prime}$.

OEVIATION DATA N.D.

$865^{\prime}$

V.O.

$865^{\prime}$

REFERENCE SUR 403

HOLECOORONATES@

$865^{1} \quad$ N835, 600.27

$\mathrm{E} 688,399.06$

CORING HISTORY

None taken

REVISION

DATE

Warch 9, 1963

WRITTEN BY

CHECKEO BY 
Well History

Str. II-3bh

\author{
6-7-62 Moved in Bucket rig and drilled 64" hole to 80 ' Moved out. \\ 6-8-62 Moved in Portadrit1 and ran and cemented 54 " casing at $80^{\prime}$ \\ with 472 cu f't. common cement with $2 \%$ HA-5. Noved out. \\ 6-16-62 Moved in Oilwell 860 and rigged up. Drilled out shoe and made \\ 15" hole to 612" using air as a drilling media. \\ 6-17-62 Drilled 15" hole from 612' to 1080'. Opened 15 " hole to 26" \\ from 801 to 7661 . \\ 6-18-62 Cpened 15" hole to 26" from 766' to 1080'. Opened 26" hole to \\ 42." irom 80' to 368'. \\ 6-19-62 Opened $26 "$ hole to $42 "$ from 368 ' to 7481. \\ 6-20-62 Opened 26" hole to $42^{\prime \prime}$ from 7481 to $855^{\prime}$. Cleaned tisht hole. Hole \\ filled in to 826, , bit plugged working stuck pipe. \\ $6-21 \times 62$ Ran inside of drill pipe with $1 \frac{1}{4}$ tubing to 471 ' and blew drill pipe \\ free of sand. Rig secured for 3 hours. Ran tubing on to bit and blew \\ drill pipe clean. Pulled tubing and got normal returns. Worked pipe \\ \& it came free. \\ 6-22-62 Cleaned out from 768' to 809'. Air drilling head blew off, Worked \\ pire cut of tight hole, had to single out. Bit is plugked. Worked pipe \\ up to 608 . \\ 6-23-62 Worked pipe out of the hole. Ran in hole with li2" drilling assembly \\ and cleaned out to 685'. Plug ed bit. Pulled out of hole and cleaned \\ bit. Ran in and cleaned out ill to 575' and plugged the bit. Pulled \\ out, rieaned bit and re-ran same. Cleaned out to 68?'. \\ 6-24-62 Cleaned out to 855'. Cpened hole to $42 "$ from 855' to 869'. The above \\ sloughing, trouble was attributed tc bad water, and soap that was not com- \\ patible with water. \\ 6-25-62 Opened hole from 869' to 675\%. Puiled out and re-ran to check for fill. \\ Cleaned out fill. f'rom $40^{\prime}$ to $75 '$. Conditioned hole. Pulled out and \\ re-ran, pipe stopped at 680'. Reamed tisht hole from $670^{\prime}$ to $875^{\prime}, 49^{\prime}$ \\ fill. Conditioned hole. \\ 6-26-62 Nade trio up to casing and ran back and found top of fill at 827 ' \\ (4o' fill). Cleaned out to 875" and opened $26 "$ hole to $42 "$ from \\ 8751 to 938. Made round trip to check pill. Ton of fill 718 t to \\ $857^{\prime}$.
}




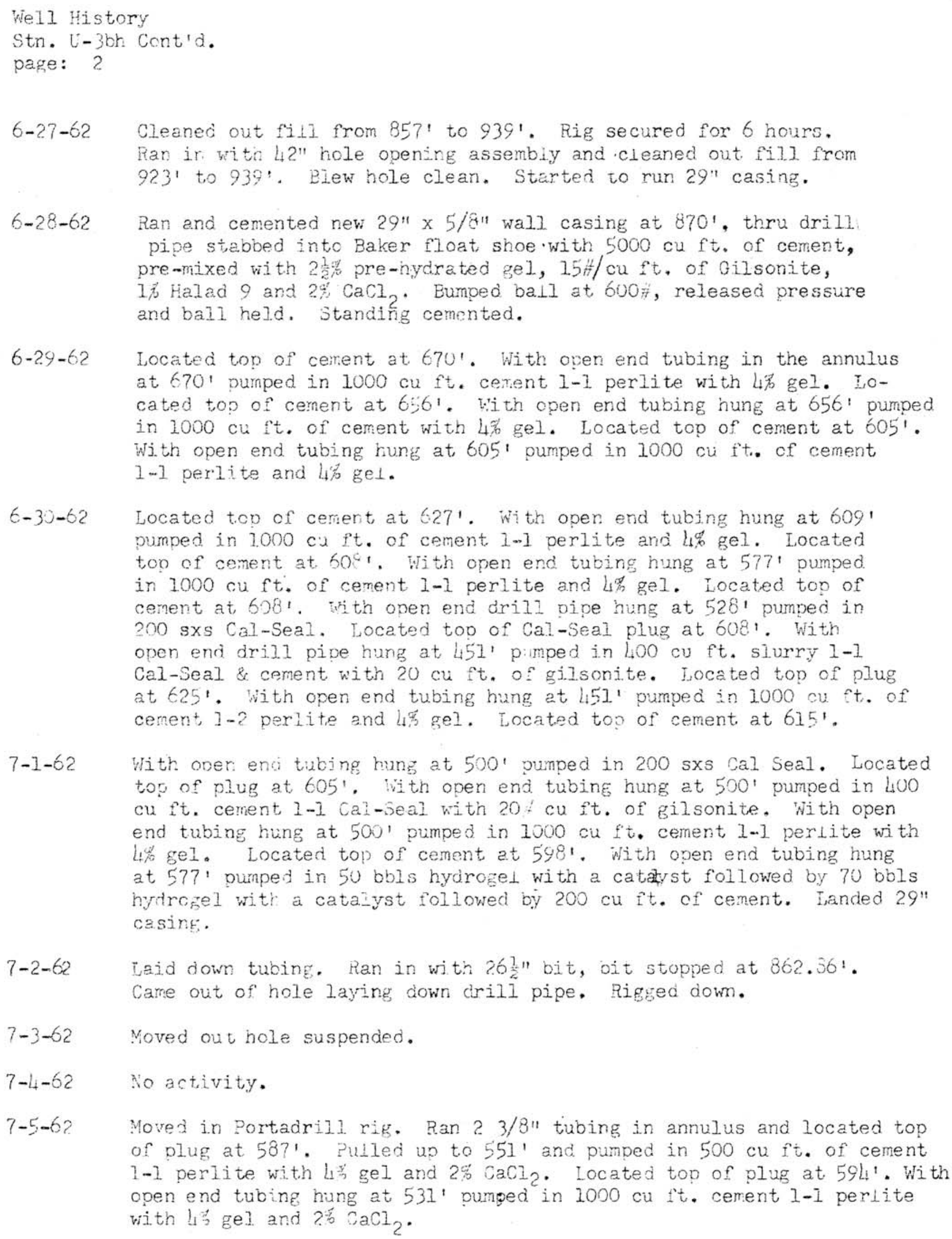

6-29-62 Located top of cerrent at 670'. With open end tubing in the annulus at 670 pumped in $1000 \mathrm{cu}$ ft. cerent 1-1 perlite with L范 gel. Iocated top of cement at 6;6'. With open end tubing hung at 656: pumped in $1000 \mathrm{cu} \mathrm{ft}$. of cement with 4\% gel. Located top of cement at $605{ }^{\circ}$. Wi.th open end tubing hung at 6051 pumped in $1000 \mathrm{cu} f \mathrm{ft}$. of cement $1-1$ perlite and $4 \%$ ge 1 .

$6-30-62$ Located top of cerent at $627^{\prime}$. Wi th open end tubing hung at 6091 pumped in $1.000 \mathrm{cu} \mathrm{ft}$. of cement $1-1$ perlite and Lo gel. Located ton of cement at $60^{\circ}$. With open end tubing hung at $577^{\circ}$ pumped in $1000 \mathrm{cu} \mathrm{ft}$. Of cement $1-1$ perlite and L\% gel. Located top of cenent at, $608 \%$. Whith open end drill pipe hung at 5281 pumped in 200 sxs Cal-Seal. Located top of Cal-Seal plug at 608'. With open end drill pipe hung at 451 ' p:mped in $400 \mathrm{cu} f t$. slurry $1-1$ Cal-Seal \& cement with 20 cu ft. of gilsonite. Located top of plug at $625{ }^{\prime}$. With open end tubing hung at $451^{\prime}$ pumped in $1000 \mathrm{cu} \mathrm{ft}$. of cenent 1-2 perlite and $4 \%$ gel. Located to of cement at 615 '.

7-1-62 With oper enci tiabing hung at $500^{\prime}$ pumped in 200 sxs Cal Seal. Located top of plug at $605 \%$. With open end tubing hung at $500^{\circ}$ pumped in 400 cu ft. cement 1-I Cai-seal with 20 cu ft. of gilsonite. With open end tubing hung at 500 ' pumped in $1000 \mathrm{cu} \mathrm{ft}^{\prime}$. cement 1-I perlite with $4 \%$ gel. Located top of cement at 5981. With open end tubing hung at $577^{\prime}$ pumped in 50 bbls hydrogel with a catayst followed by 70 bbls hydrogel with a cataiyst followed by 200 cu it. of cement. Landed 29" casine.

7-2-62 Laid down tubing. Ran in with $26 \frac{1}{2}$ " bit, bit stopped at 862.36:. Came out of hole laying down drill pipe. Rigged down.

7-3-62 Moved out hole suspended.

7-4-62 No activity.

7-5-6? Moved in Portadrill rig. Ran $23 / 81$ tubing in annulus and located top of plug at 587'. Pulled up to $551^{\prime}$ and pumped in $500 \mathrm{cu}$ ft $^{\prime}$ of cement 1-I perlite with $L^{\prime}$ gel and $2 \% \mathrm{CaCl}_{2}$. Located top of plug at 594'. With open end tubing hung at $531^{\prime}$ pumped in $1000 \mathrm{cu} \mathrm{ft}^{\prime}$, cement $1-1$ perlite with $4:$ gel and $2 \% \mathrm{CaCl}_{2}$. 
Well history

Stn. U-3bh Cont'd.

page: 3

7-6-62 Located top of Cement at 571'. Rig secured 7 hours. Rig moved out \& 1230hours.

$7-7-62$

Thru

$7-9-62$

No activity.

7-10-62 Moved in National. T-20 rig and rigged up to pump sand in the annulus. located top of cement in annulus at 562'. Dumped in a total of 1280 cu, ft. of sand. Located top of sand at 519:.

7-11-62 Pulled up to 365' and pumped in $248 \mathrm{cu} f$. of Cal seal. Checked top of plug at 506'. Dumped in $2240 \mathrm{cu} \mathrm{ft}$. sand. Located top of plug at 511'. Pumped in 200 sxs Cal-Seal. Located top of plug at 506'.

7-12-62 Dumped in $1320 \mathrm{cu} f t$. sard. Located top at 4461. Pumped in 200 sxs Cal-Seal followed by 1000 cu ft. cement $1-1$ perlite with $4 \%$ gel \& $2 \%$ $\mathrm{CaCl}$. $1 \frac{1}{2}$ hours wait between jobs. Dumped $1600 \mathrm{cu} \mathrm{ft}$. sand in annulus, ${ }^{2}$ located top at $437^{\prime}$. Hoved out National $\mathrm{T}-20 \mathrm{rig}$ and moved in AEC Failing 2500. Pumped in $1200 \mathrm{cu} f t$. perlite \& $400 \mathrm{cu} \mathrm{ft}$. of sand. Pumped in $1320 \mathrm{cu}$ ft. perlite \& $400 \mathrm{cu}$ ft. sand.

7-13-62 Rig secured 3 hours. Pumped in $200 \mathrm{cu} f \mathrm{f}$. cement with 1-1 Gal-Seal. Located top of cement at $424^{\prime}$. Pumped in $500 \mathrm{cu}$ ft. cement $1-1$ perlite with $4 \%$ gel. Checked top of plug at 422 '.

7-1L-62 Dumped in $800 \mathrm{cu} \mathrm{f}^{\prime} \mathrm{t}$. sand and located top at. 4I51. Pumped in $500 \mathrm{cu}$ et. cement 1-1. perl te with $4 \%$ gel and $2 \% \mathrm{CaCl}_{2}$. Located top of plug at 4161 . Blew in $800 \mathrm{cu} f t$. sand. Checked bottom at 4081 . Blew in $880 \mathrm{cu} \mathrm{ft}$. Of sand, checked plug at $402^{\prime}$.

7-15-62 Blew in $880 \mathrm{cu} f$ t. of sand and gravel. Located top of plug at 401'. Pumped in 840 cu $\mathrm{ft}$. of sand in hole. Located top of plug at $387 \%$ Pumped in 210 cu $\mathrm{ft}$. of sand with tubing hung at 3051 .

7-16-62 Pumped in $810 \mathrm{cu} f t$. of sand with tubing hung at 305'. Checked top of plug at $297^{\circ}$. Pumped in $210 \mathrm{cu} \mathrm{ft}^{\prime}$. sand with tubing hung at $275^{\prime}$ and cemented with $500 \mathrm{cu} \mathrm{ft}$. cement with $1-1$ perlite, $4 \%$ gel and $2 \% \mathrm{CaCl}_{2}$. Checked top of plug at 2851 . Cemented with $1000 \mathrm{cu}$ ft. cement with $4 \%$ gel and $2 \% \mathrm{CaCl}$. Located top of plug at 173'. With tubing hung at

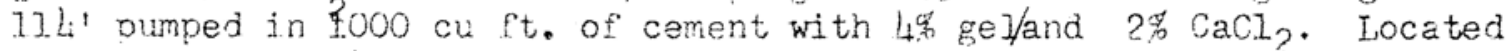
top of plug at $145^{\prime}$. With tubing hung at $125^{\prime}$ pumped in $1000 \mathrm{cu} \mathrm{ft}$.' cement 1-1 perlite with 4 罗 gel and $2 \% \mathrm{CaCl}_{2}$. Checked fluid level in 29" casing at 407'. Located top of plug at 90'. Moved out rig. 
We]l History

Str. U-3bh Cont'd,

page: L

7-17-62 Moved in Ideco $\mathrm{H}-35$ and rigged up. Picked up 2611 bit and checked top of cement in casing at $865.61 \%$. With tubing hung at 601 in annulus pumped in $500 \mathrm{cu} f t$. cement $1-1$ perlite. Located top of cement at 35 '.

$7-18-62$

Pumped in $400 \mathrm{cu} \mathrm{ft}$. of neat cement, annulus filled to surface. Ran Sperry Sun Gyroscopic Multishot survey from surface to 8651 . Scraped 29" casing. Made mandrel run to $865^{\prime} .84$ '. Swabbed hole with tire swab. Laid down swab and bailed the hole.

7-19-62 Bailed hole and swabbed. Received orders to plug hole back. With open end drill pipe hung at $864^{\prime}$ plugged $29^{\prime \prime}$ casing with $660 \mathrm{cu}$ ft. cement with $2 \% \mathrm{HA}-5$. Located top of plug at $685^{\circ}$.

7-20-52 Ran in with 26" bit and drilled out cement to 720'. Scrapped 29" casing. Swabbed 29" casing.

7-21-62 Bailed hole and ran dry swab. Measured in with $26 \frac{1}{2}$ mandrel to check working point, in and out 717.92'. Laid down drill pipe. Rigged down and moved out. Hole completed 7-21-62. 


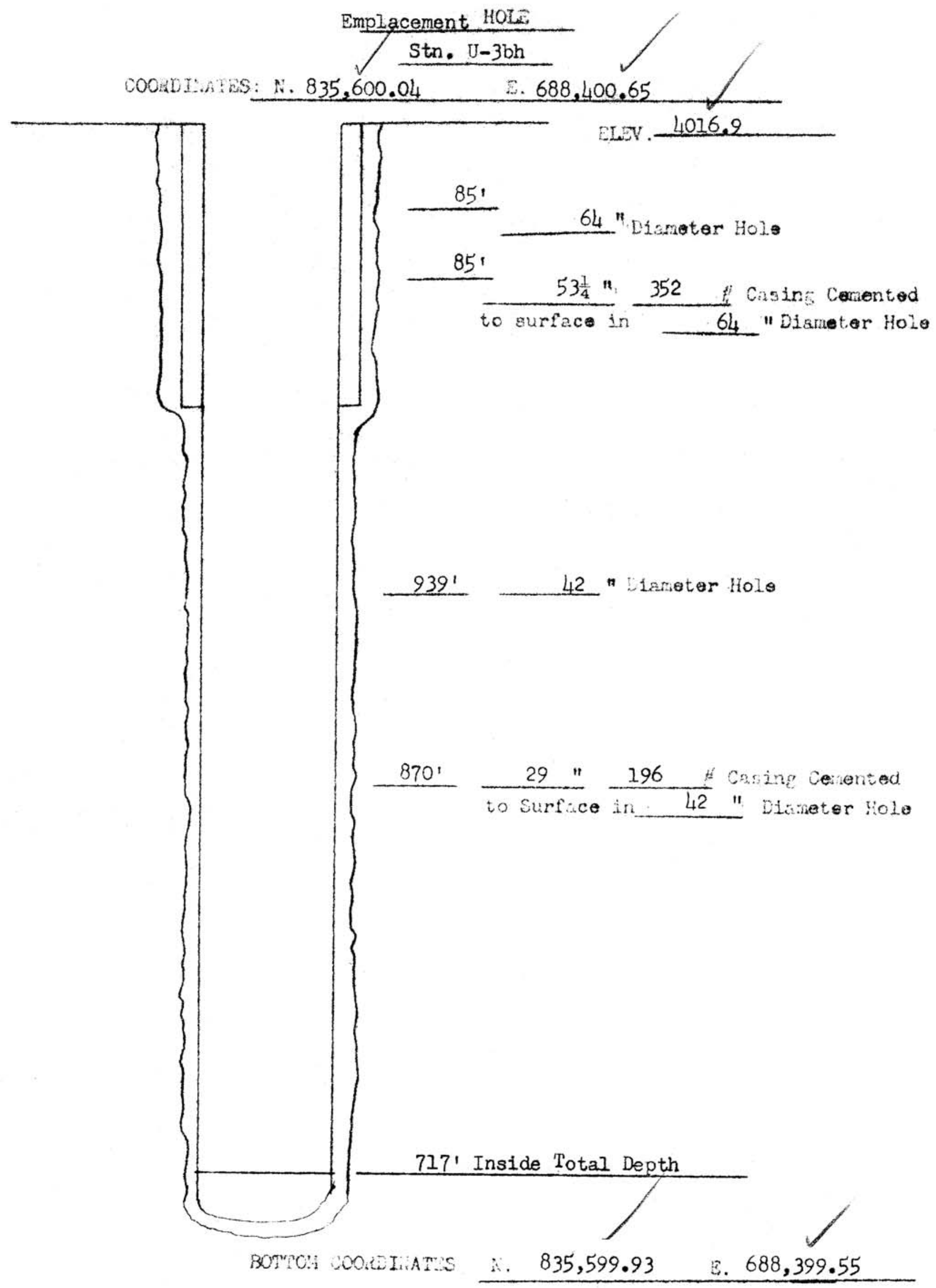


HOLMES \& NARVER, INC.

WELL HISTORY DATA

HOLE NUMBER U-3bg

WORK ORDER NUMBER

$1215-20$

H\& N I.D. NUMBER 182720

E.D.S. NUMBER

USER -

LASL

LOCATION:

Nevada - NTS

$\int$ County

TYPE HOLE Emplacement

Coordinates N8836,399.68

E688, 400.45

Nye Area

Surface Elevation

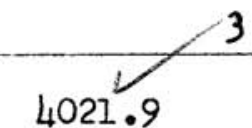

4021.9

RIG SCHEDULE: MOVED ON LOCATION_5-28-62 SPUDDED 5-29-62 COMPLETED $6-20-62$

REMARKS: Hole idle from 6-15-62 to 6-19-62 InCl. USER ACCEPTANCE _ 6-20-62

MUD PROGRAM:

Air

DRILLING EQUIPMENT.

Oilwell 860 thru pumping out stage. National T-20 to complete.

\begin{tabular}{|c|c|c|c|c|c|c|c|c|c|}
\hline \multicolumn{3}{|c|}{ BORE HOLE RECORD } & \multicolumn{7}{|c|}{ CASING RECORD } \\
\hline FROM & TO & SIZE & SIZE & WEIGHT & GRADE & COUPLING & FROM & TO & $\begin{array}{c}\text { SACKS } \\
\text { CEMENT }\end{array}$ \\
\hline $0^{1}$ & $80^{1}$ & $60^{\prime \prime}$ & $54 "$ & $352 \#$ & & $B$ W & 01 & 801 & $650 \mathrm{cu} \mathrm{ft}$ \\
\hline 801 & $875^{\prime}$ & $42^{\prime \prime}$ & $29^{\prime \prime}$ & $198 \#$ & $J-55$ & $B W$ & $Q^{\prime}$ & 8711 & 9555 cu ft \\
\hline 8751 & $1080^{\prime}$ & $26 "$ & & & & & & & \\
\hline & & & & & & & & & \\
\hline & & & & & & & & & \\
\hline
\end{tabular}

TOTAL DEPTH_ WORKING POINT_ $1080^{\prime} \quad$ 865.04' PLUGS 1080' $875^{\prime}$
JUNK None

LOGGING DATA

Lane Wells temperature survey to 865'. Sperry Sun gyroscopic multishot directional survey from surface to $868^{\prime}$.

DEVIATION DATA: M.D.___ $865^{\prime} \quad$ V.D. BOTTOM HOLE COORDINATES (a) $865^{\prime} \mathrm{N} 836,400.91, \mathrm{E} 688,400.16$ 
Well History

Sta. U-3bg

5-26-62 Moved in bucket rig and drilled 60" hole to $80^{\prime}$.

5-27-62 Ran and cemented 54" casing at 80 ' with $650 \mathrm{cu} \mathrm{ft}$. cement with $2 \%$

$\mathrm{CaCl}_{2} \cdot$

5-28-62 Moved in 0ilwell 860 and rigged up.

5-29-62 Completed rigging up. Drilled out shoe with center punched set and made $15^{\prime \prime}$ hole to $86^{\prime}$ using air as a circulating media.

5-30-62 Drilled 15' hole from 86' to $148^{\prime}$.

5-31-62 Drilled 15" hole from 148 ' to 690 '.

6-1-62 Drilled 15" hole from 690' to 1080'. Opened 15" hole to 26" from $80^{\prime}$ to $305^{\prime}$.

6-2-62 cpened 15" hole to $26 "$ from $305^{\prime}$ to $1080^{\prime}$.

6-3-62 Opened 26" hole to $42^{\prime \prime}$ from $80^{\prime}$ to $750^{\prime}$.

6-4-62 Opened 26" hole to 42" from 750' to 875'. Ran in with 15" bit and it stopped at 876'. Ran in $42 "$ drilling assembly and found 37 ' of fill (838'). Pulled out and re-ran same assembly in 4 hours to check fill, found 50 ' (825'). Cleaned out fill to 875' and blew hole clean.

6-5-62 Checked fill after 4 hours, found 1' (874'). Rechecked fill after 8 hours, no fill.

6-6-62 Rig secured 5 hours. Checked fill, bit went to 875'. Started to run $29^{\prime \prime}$ casing.

6-7-62 Ran and cemented new 29" I.D. x 5/8" wall casing at 870.87 ', thru drill pipe stabbed into Baker float shoe with $4100 \mathrm{cu} f t$. of cement pre-treated with $15 \#$ cu ft. gilsonite, $2 \%$ pre-hydrated gel, $1 \% \mathrm{Halad} 9$ and $2 \% \mathrm{CaCl}_{2}$.

6-8-62 Stood cemented 8 hours. Ran Lane Wells Temperature log and located top of cement at $400^{\prime}$. Ran tubing in the annulus to $400^{\prime}$ and pumped in 1000 cu ft. of cement 1-1 perlite and $2 \% \mathrm{CaCl}_{2}$. Ran Sperry Sun Gyroscopic survey from surface to $865^{\prime}$. Located top of cement at $225^{\prime}$ with open end tubing hung at $210^{\prime}$ pumped in $1000 \mathrm{cu} \mathrm{ft}$. of cement $1-1$ perIite and $2 \%$ $\mathrm{CaCl}_{2}$. With open end tubing hung at 200' pumped in $1000 \mathrm{cu} \mathrm{ft}$. of cement 1-l perlite with $2 \% \mathrm{CaCl}_{2}$. With open end drill pipe hung at 150 pumped in $1000 \mathrm{cu} \mathrm{ft}$. cement $1-\overline{1}$ perlite and $2 \% \mathrm{CaCl}_{2} \cdot$

6-9-62 With open end tubing hung at $90^{\prime}$ pumped in $1000 \mathrm{cu} \mathrm{ft}$. cement 1-1 perlite and $2 \mathrm{CaCl}_{2}$. With open end tubing hung at 42 ' pumped in $455 \mathrm{cu} \mathrm{ft}$. neat cement. Cement to surface. Used total of $9555 \mathrm{cu} \mathrm{ft}$. 
Well History

Sta. U-3bg

page: 2

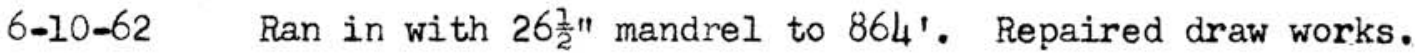

6-11-62 Repairing draw works.

6-12-62 Repairing draw works.

6-13-62 Repairing draw works.

6-14-62 Ran B-J submersible pump and pumped fluid out of hole. Tore out and moved rig.

$6-15-62$

Thru

$6-19-62$

No activity.

6-20-62 Noved in National T-20 rig. Bailed hole dry. Ran 26 $\frac{1}{2}$ mandrel and established working point of $865.04^{\prime}$. Laid down drill pipe and moved out. Well completed 9-20-62. 
Emplacement HOLE

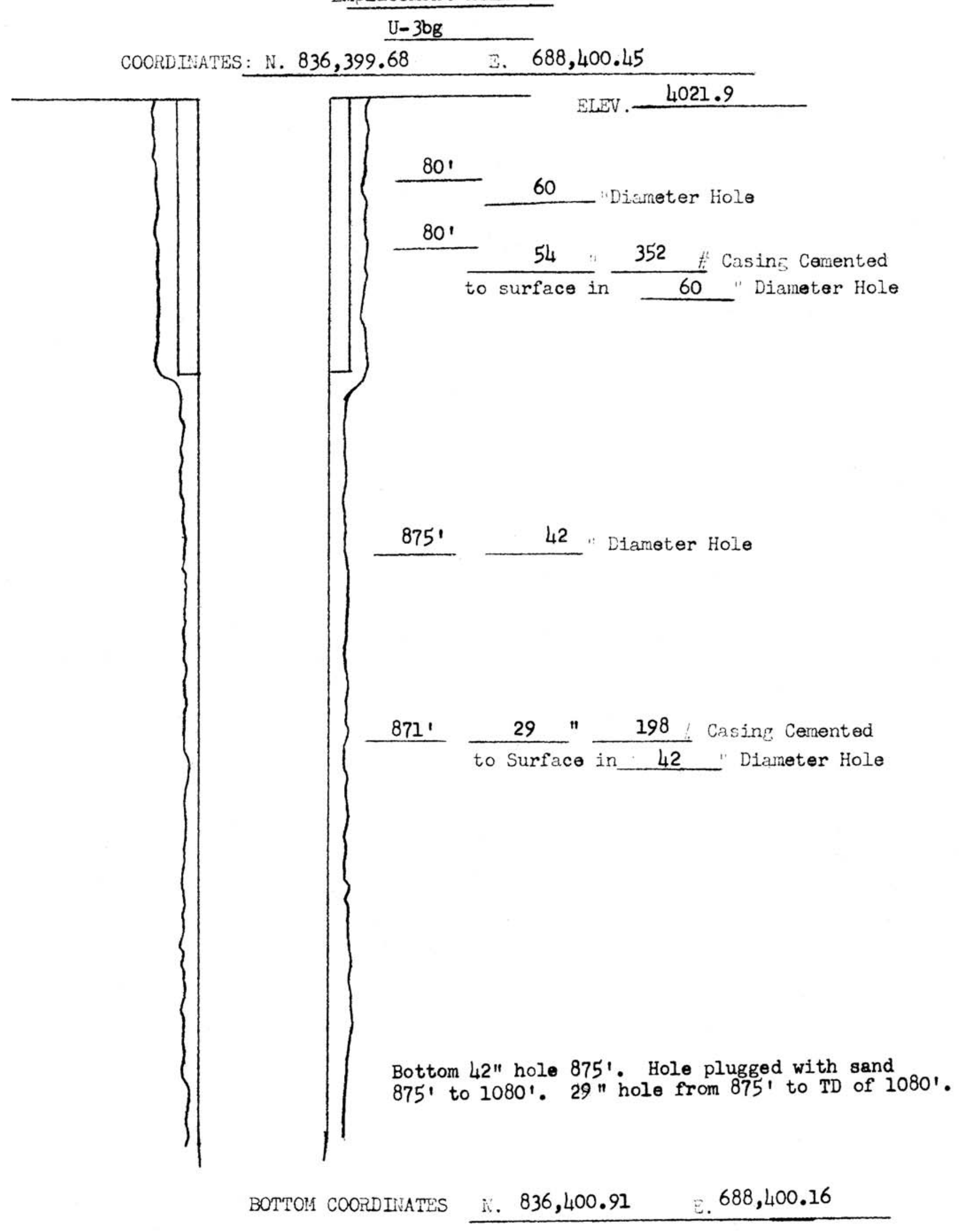




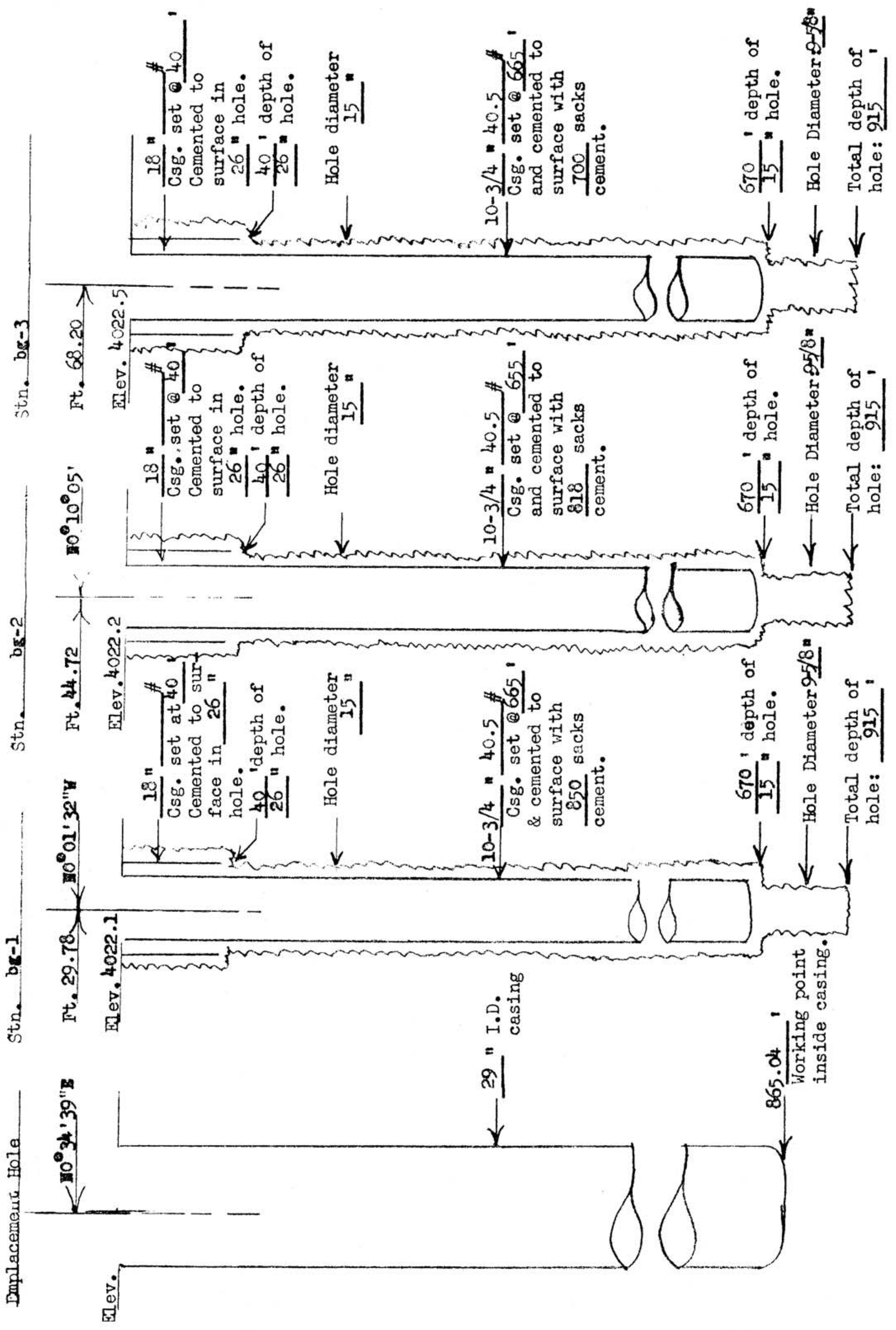




\section{Appendix B}

Construction information for all holes drilled within the RWMS

Note: The satellite holes were drilled prior to the event for installation of instrumentation and backfilled with sand to approximately $30 \mathrm{~m}$ from the surface and cemented from there to the surface. Post-shot holes were drilled to obtain samples for radiochemical analyses. There are no records of how the vertically-drilled post-shot holes were left, but it was common practice to just install a welded cap, blind flange or slide valve on the top of the surface casing and not backfill these holes drilled within the surface collapse crater holes. PrePost-shot holes were started with a surface casing but not used. 


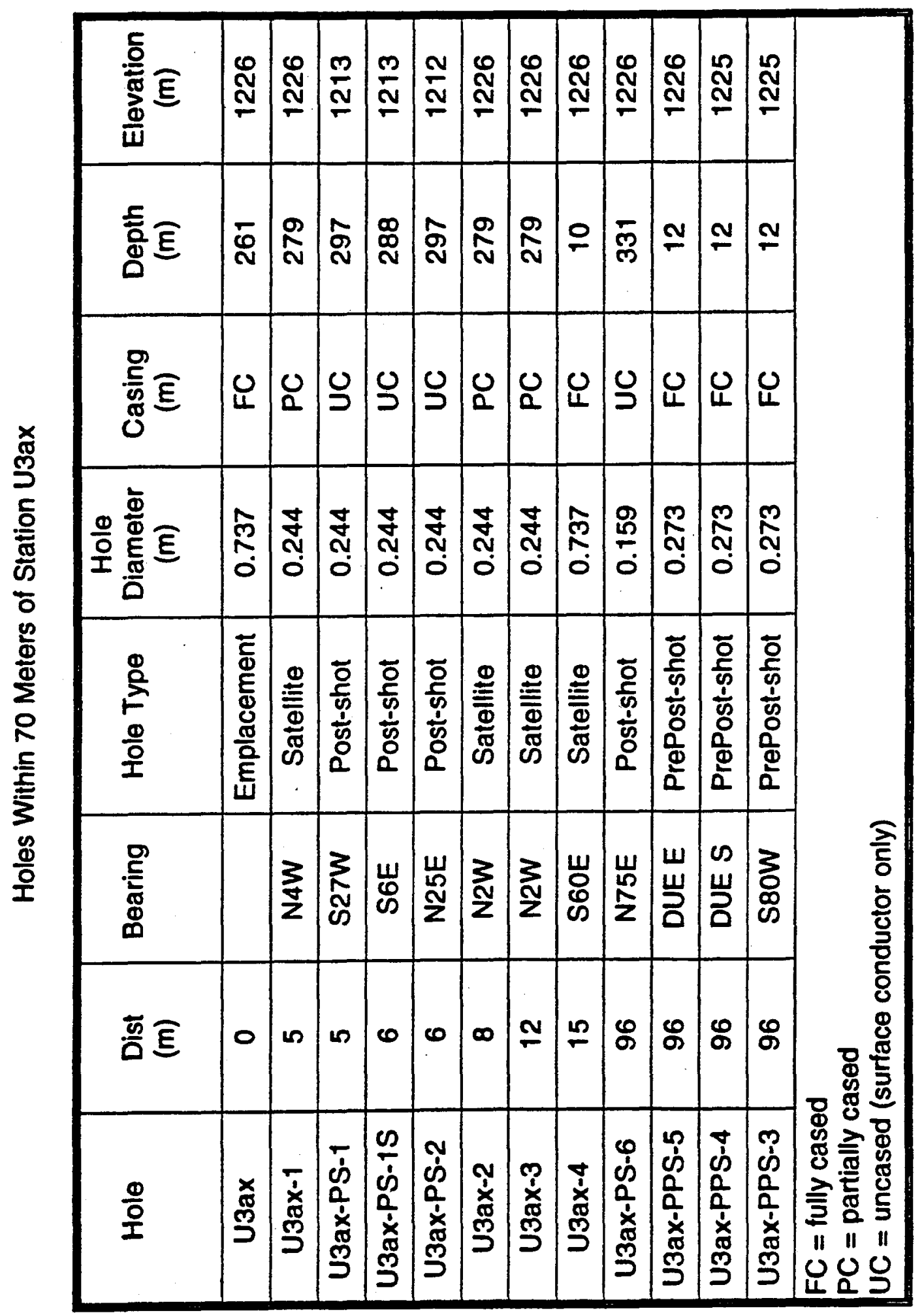




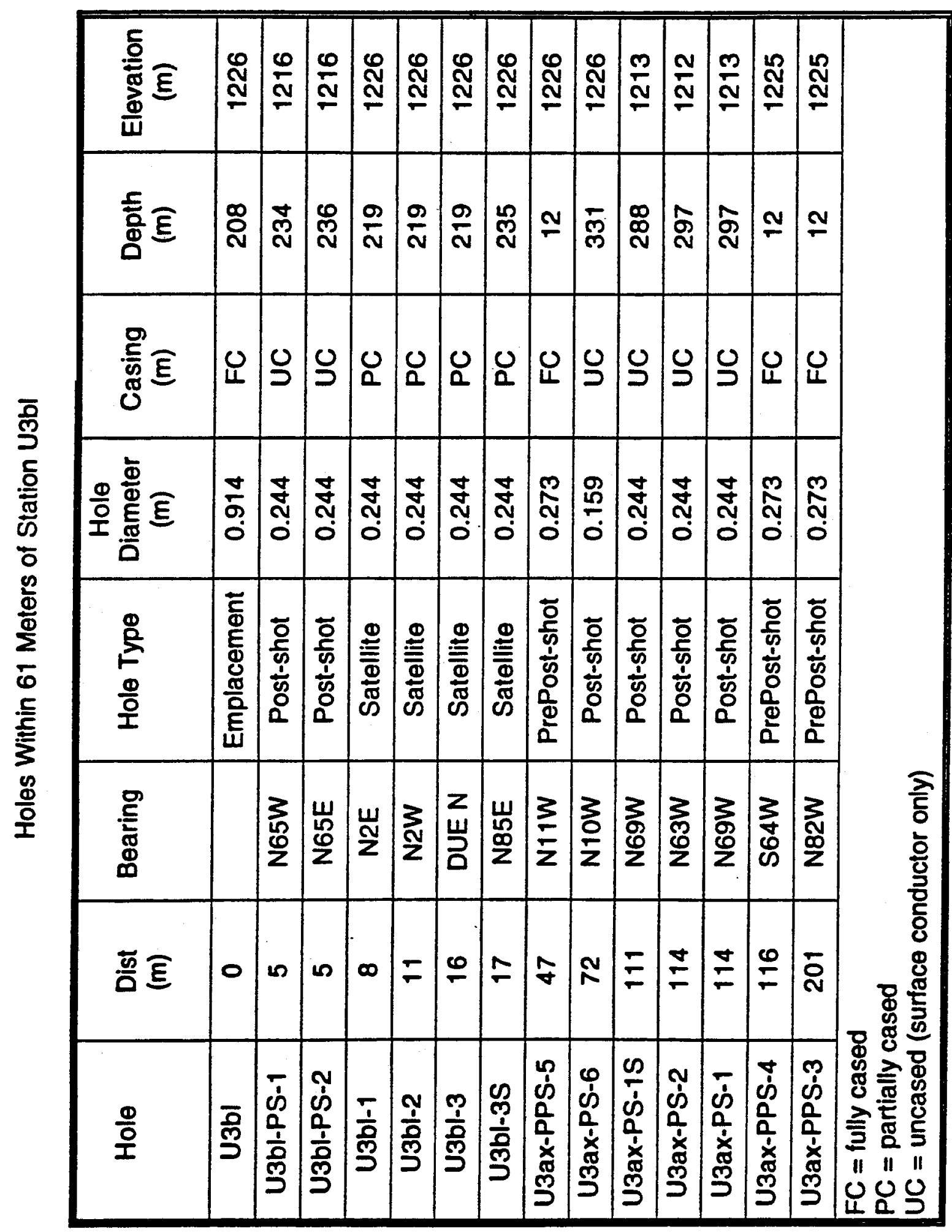




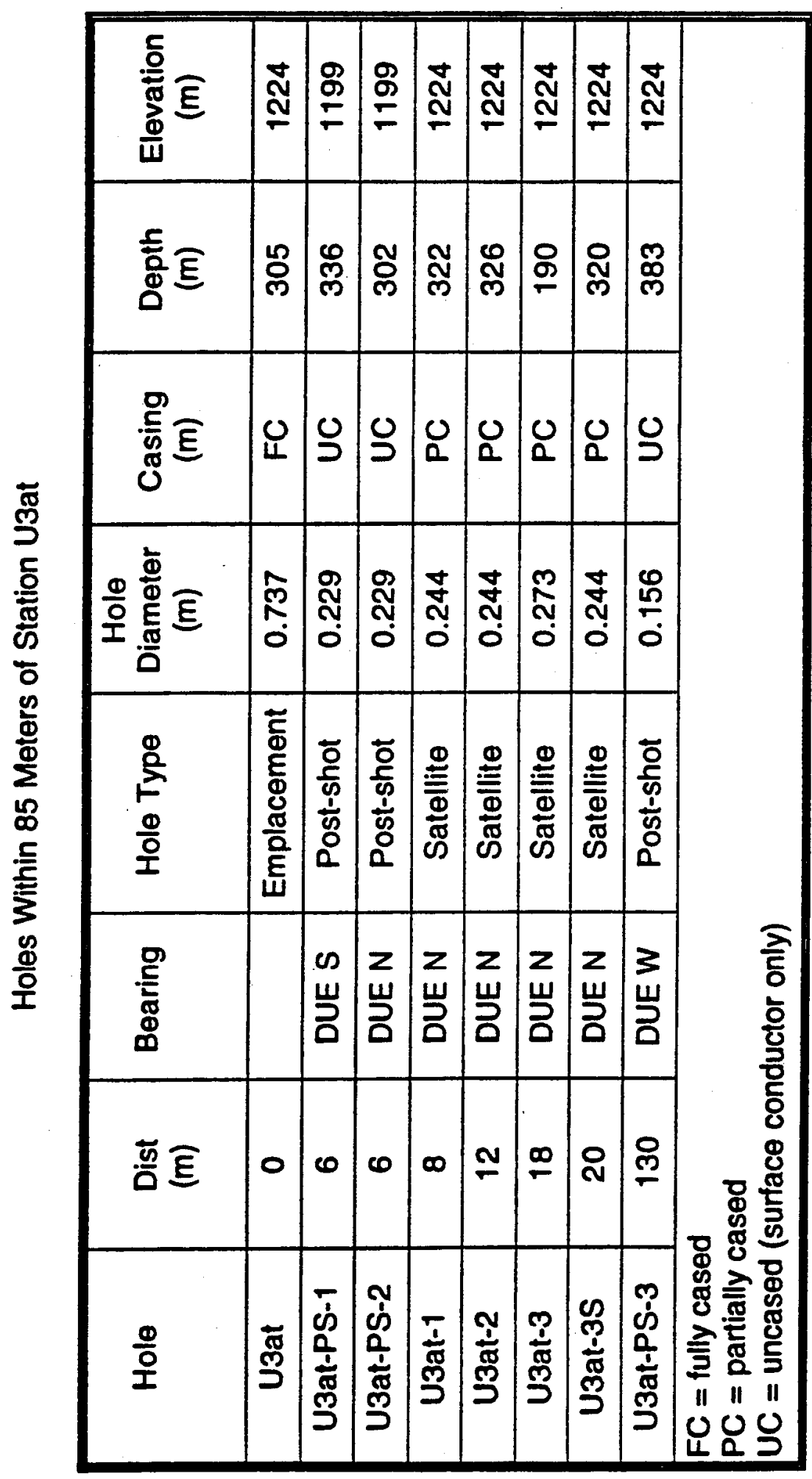




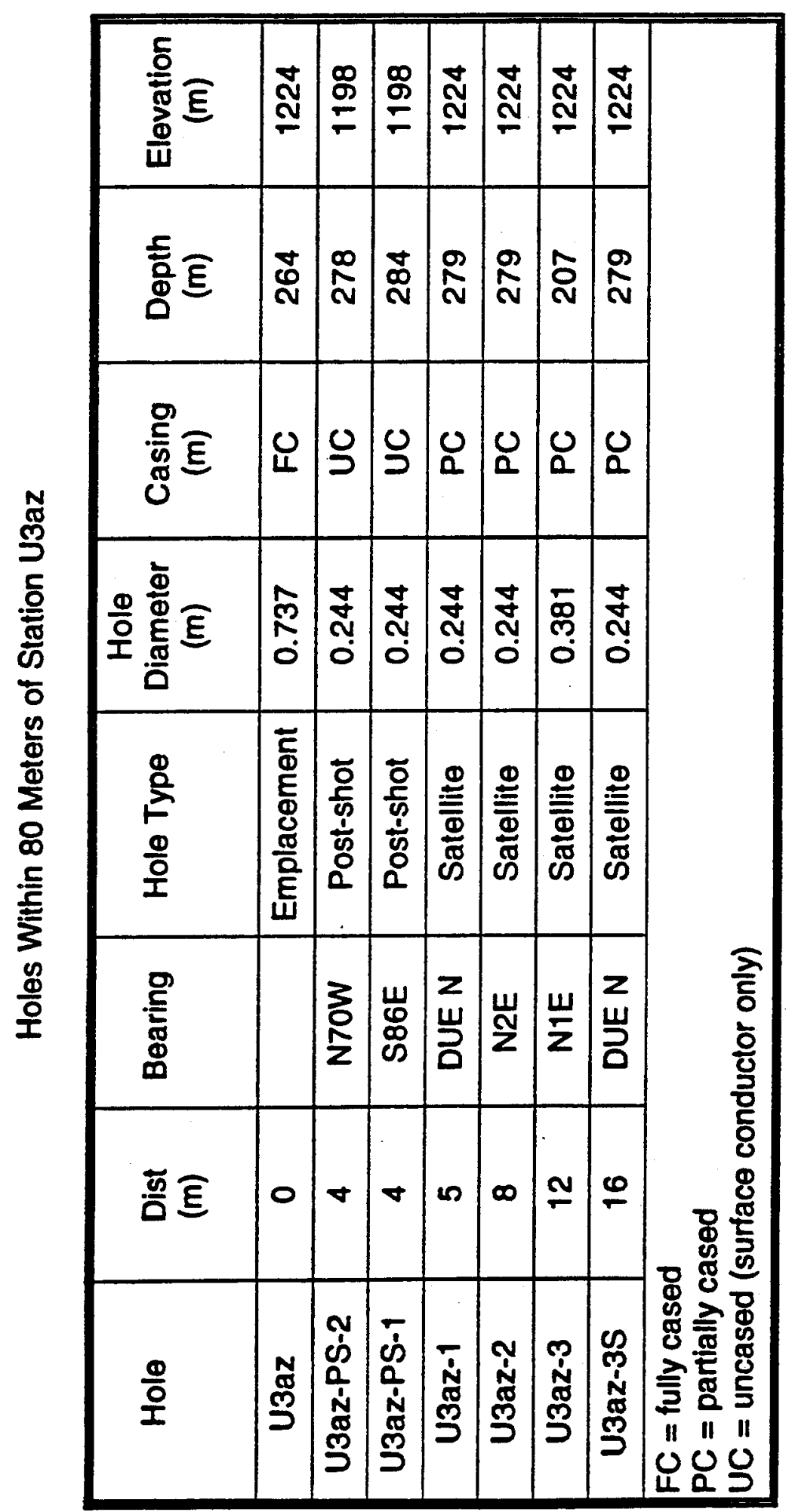




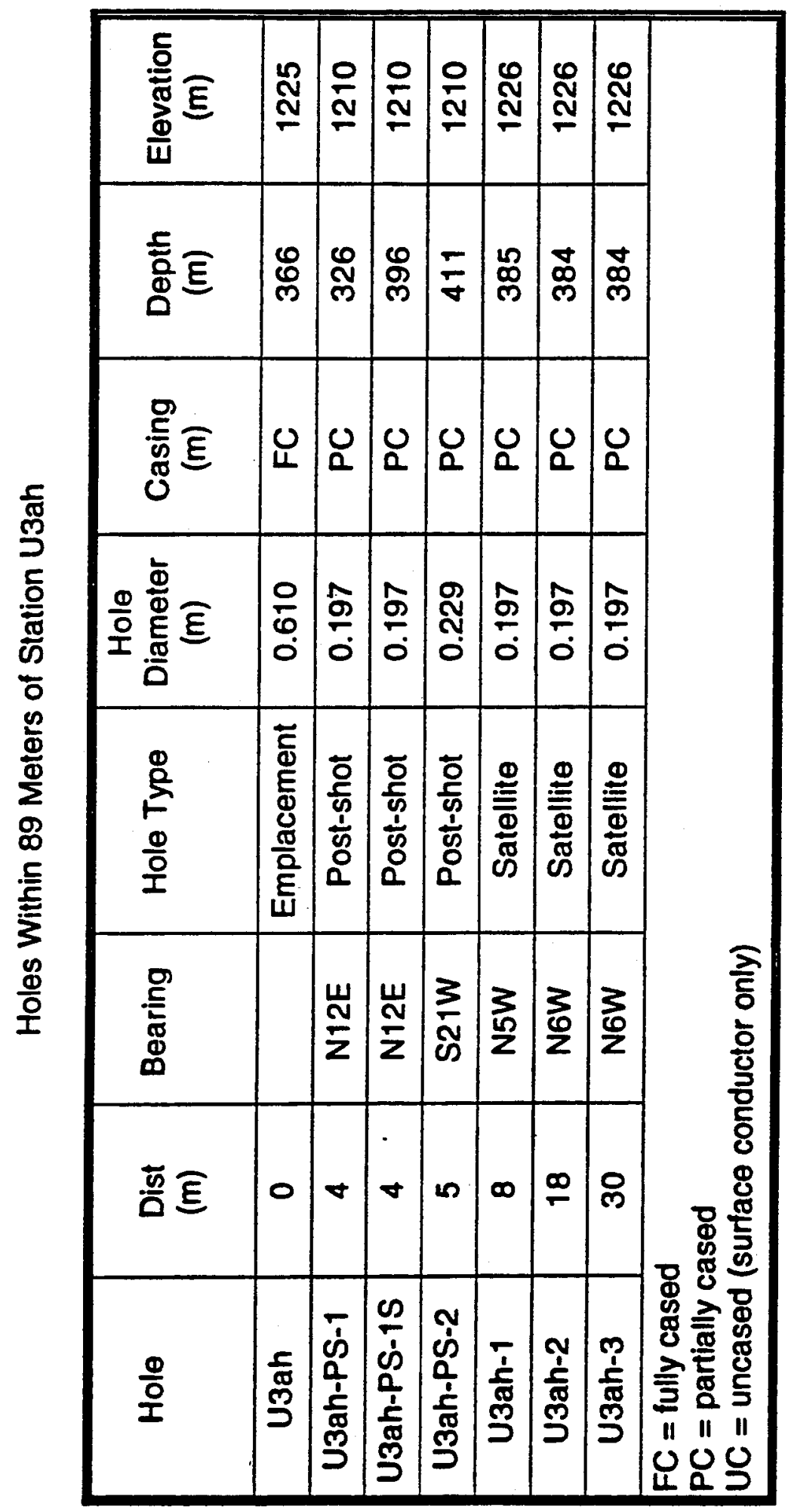




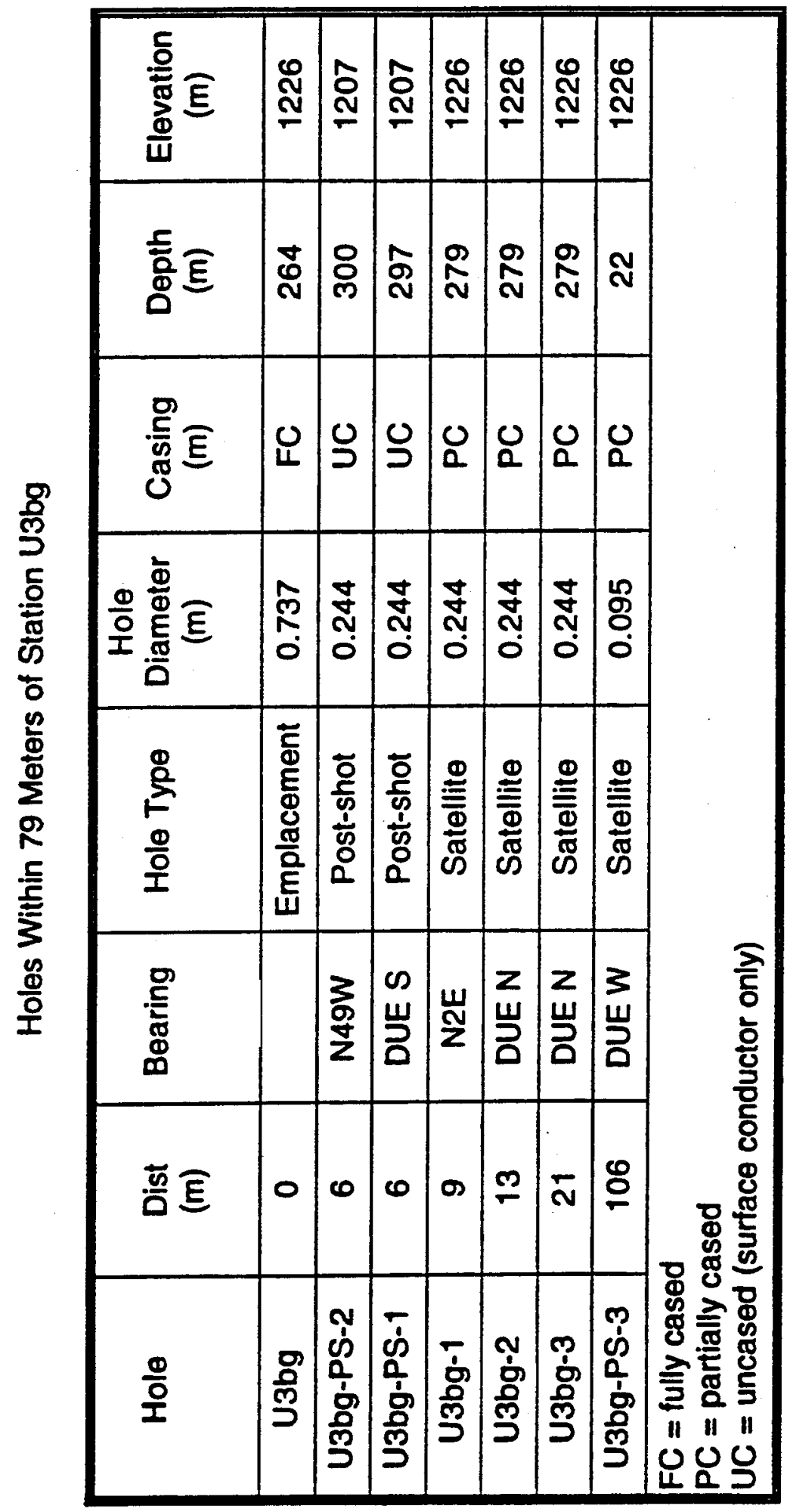




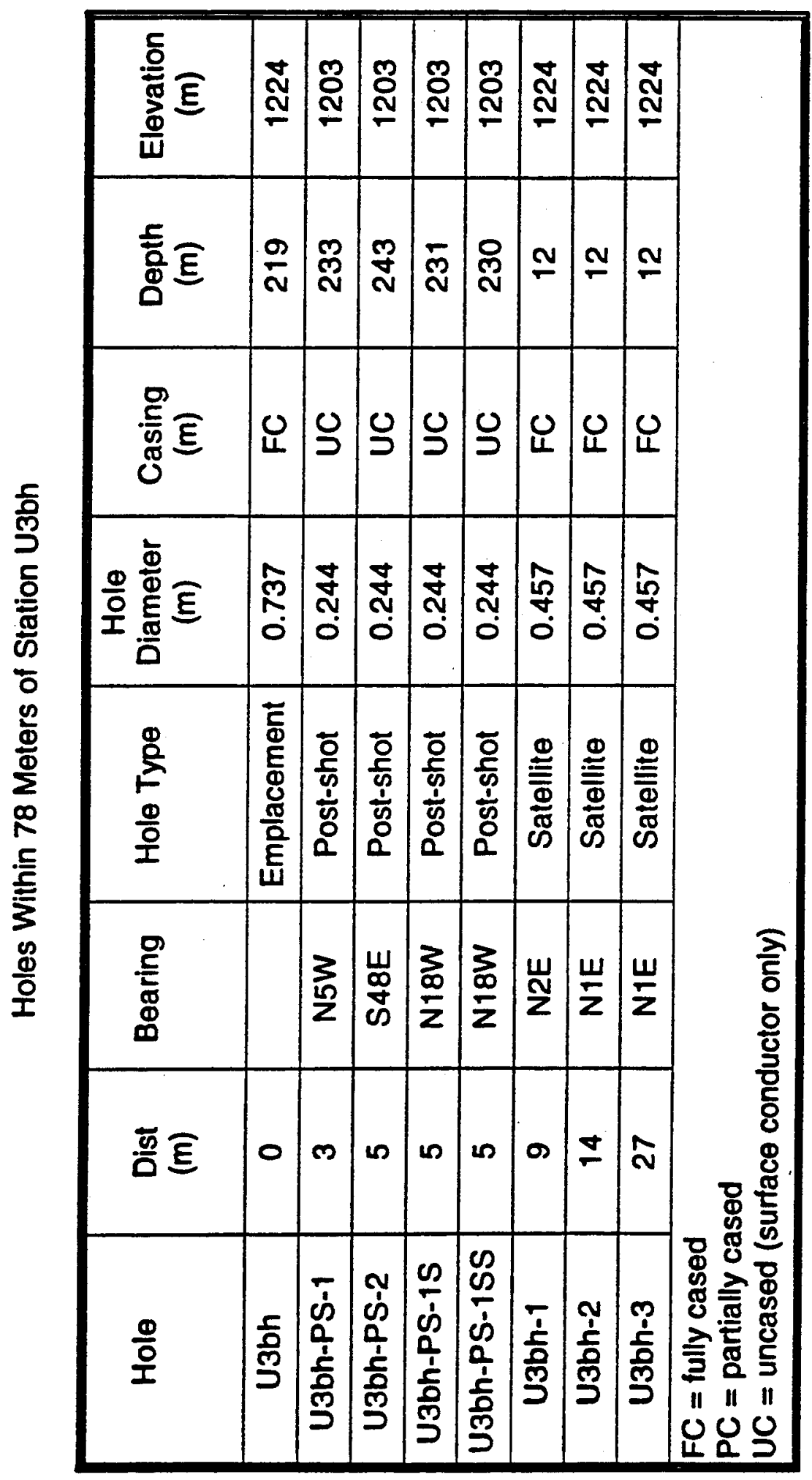




\section{Appendix C}

Boreholes measurements made in the RWMS emplacement holes

Note: See Table 7 for explanation of log abbreviations. 
Hole U3az

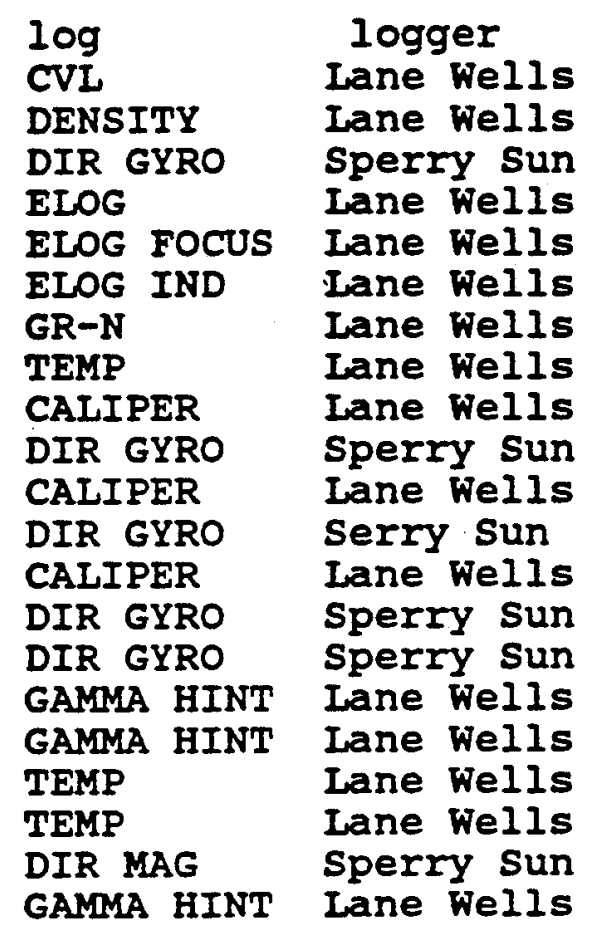

Hole U3bg

$\begin{array}{ll}\text { log } & \text { logger } \\ \text { DIR GYRO } & \text { sperry sun } \\ \text { TEMP } & \text { Lane Wells } \\ \text { DIR GYRO } & \text { Sperry Sun } \\ \text { DIR GYRO } & \text { sperry Sun } \\ \text { DIR GYRO } & \text { Sperry Sun } \\ \text { DIR MAG } & \text { sperry Sun } \\ \text { GAMIA HINT } & \text { Lane Wells } \\ \text { DIR MAG } & \text { Sperry Sun }\end{array}$

Hole U3bh

$\begin{array}{ll}\text { IOg } & \text { logger } \\ \text { DIR GYRO } & \text { Sperry sun } \\ \text { DIR KAG } & \text { Sperry Sun } \\ \text { GAMMA HINT } & \text { Lane WeIls } \\ \text { DIR KAG } & \text { Sperry Sun } \\ \text { GAMMA HINT } & \text { Lane Wells }\end{array}$

$$
\begin{aligned}
& \text { depth interval } \\
& \text { 680. to } 878 \text {. } \\
& \text { 680. to } 881 \text {. } \\
& \text { o. to } 865 \text {. } \\
& \text { 680. to } 881 \text {. } \\
& \text { 680. to } 874 \text {. } \\
& \text { 680. to } 882 \text {. } \\
& \text { 680. to } 881 \text {. } \\
& \text { 30. to } 867 \text {. } \\
& \text { 38. to } 714 \text {. } \\
& 0 \text {. to } 909 \text {. } \\
& \text { 50. to } 711 \text {. } \\
& 0 \text {. to } 920 \text {. } \\
& \text { 50. to } 714 \text {. } \\
& \text { o. to } 910 \text {. } \\
& \text { o. to } 932 \text {. } \\
& 700 \text {. to } 931 . \\
& \text { 100. to } 931 . \\
& 700 \text {. to } 931 . \\
& \text { 100. to } 931 . \\
& 0 \text {. to } 913 \text {. } \\
& 300 \text {. to } 879 \text {. }
\end{aligned}
$$

$$
\begin{aligned}
& \text { depth interval } \\
& 0 . \text { to } 865 . \\
& 100 . \text { to } 868 . \\
& 0 . \text { to } 915 . \\
& 0 . \text { to } 916 . \\
& 0 . \text { to } 917 . \\
& 0 . \text { to } 965 . \\
& 680 \text {. to } 960 . \\
& 0 \text {. to } 925 .
\end{aligned}
$$

$$
\begin{aligned}
& \text { depth interval } \\
& 0 . \text { to } 865 . \\
& 50 . \text { to } 756 . \\
& 550 . \text { to } 743 . \\
& 0 . \text { to } 695 . \\
& 500 \text {. to } 750 .
\end{aligned}
$$


Well Iogs from Area 3 Radiation Waste Management Site ( U3ax, U3bl, U3ah, U3at, U3az, U3bg, and U3bh)

Hole U3ax

IOg
CVI
DIR GYRO
ELOG
EIOG FOCUS
ELOG IND
GR-N
TEMP
CAIIPER
DIR GYRO
CAIIPER
DIR GYRO
CAIIPER
DIR GYRO
DIR MAG
GAMMA
DIR MAG
GAMMA
DIR MAG
GAMMA
DIR GYRO
GR-N
TEMP

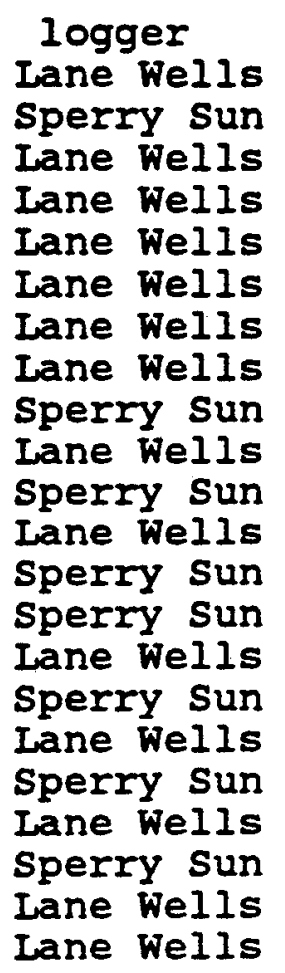

Hole U3bl

$\begin{array}{ll}\text { log } & \begin{array}{l}\text { logger } \\ \text { DIR GYRO }\end{array} \\ \text { Sperry Sun } \\ \text { DIR GYRO } & \text { Sperry Sun } \\ \text { DIR GYRO } & \text { Sperry Sun } \\ \text { DIR GYRO } & \text { sperry Sun } \\ \text { DIR MAG } & \text { sperry Sun } \\ \text { DIR MAG } & \text { Sperry Sun } \\ \text { GAMM HINT } & \text { Iane Welis } \\ \text { GAMMA HINT } & \text { Lane Wells } \\ \text { TEMP } & \text { Lane Wells } \\ \text { DIR MAG } & \text { Sperry Sun } \\ \text { GAMMA HINT } & \text { Iane Wells } \\ \text { TEMP } & \text { Lane Wells }\end{array}$

Hole U3ah

\section{logger} Schlumberger sperry sun schlumberger

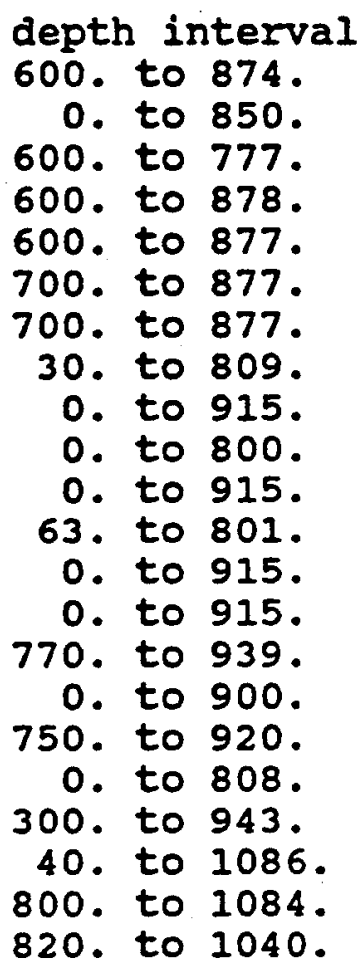

depth interval 90. to 1197.

0 . to 1200 . 90 . to 1198 .

DIR GYRO EIOG 


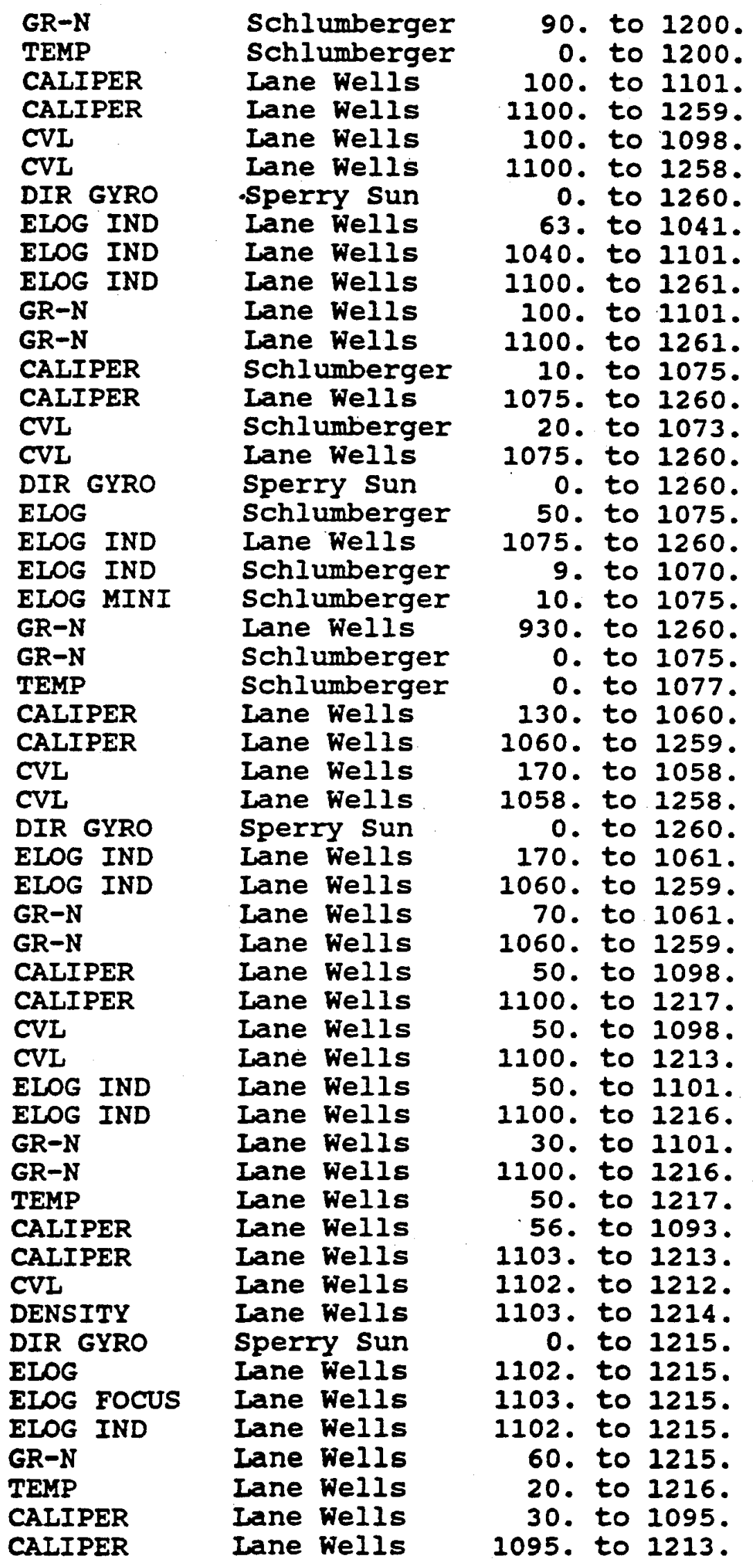




CVI
CVI
DIR GYRO
ELOG IND
EIOG IND
GR-N
GR-N
TEMP
CALIPER
CALIPER
CVI
DENSITY
DIR GYRO
ELOG
EIOG FOCUS
ELOG IND
GR-N
TEMP
DIR GYRO
DIR GYRO
TEMP
GAMMA
GAMMA
TEMP
TEMP

Iane Wells

Lane Wells

Sperry Sun

Iane Wells

Lane Wells

Lane Wells

Iane Wells

Lane Wells

Lane Wells

Lane Wells

Lane Wells

Lane Wells

Sperry Sun

Iane Wells

Lane Hells

Lane Wells

Lane Wells

Lane Wells

Sperry Sun

sperry sun

Lane Wells

Lane Wells

Lane Wells

Lane Wells

Lane Wells

$$
\begin{array}{r}
\text { 0. to } 1094 . \\
1095 . \text { to } 1212 . \\
0 . \text { to } 1215 . \\
0 . \text { to } 1088 . \\
1095 . \text { to } 1215 . \\
0 . \text { to } 1088 . \\
1095 . \text { to } 1215 . \\
620 . \text { to } 1210 . \\
65 . \text { to } 1098 . \\
1100 . \text { to } 1213 . \\
1100 . \text { to } 1212 . \\
1100 . \text { to } 1216 . \\
0 . \text { to } 1215 . \\
1100 . \text { to } 1216 . \\
1100 . \text { to } 1216 . \\
1100 . \text { to } 1215 . \\
70 . \text { to } 1215 . \\
40 . \text { to } 1216 . \\
0 . \text { to } 1000 . \\
0 . \text { to } 1300 . \\
800 \text {. to } 1298 . \\
990 . \text { to } 1350 . \\
960 . \text { to } 1263 . \\
940 . \text { to } 1264 . \\
990 . \text { to } 1350 .
\end{array}
$$

Hole U3at

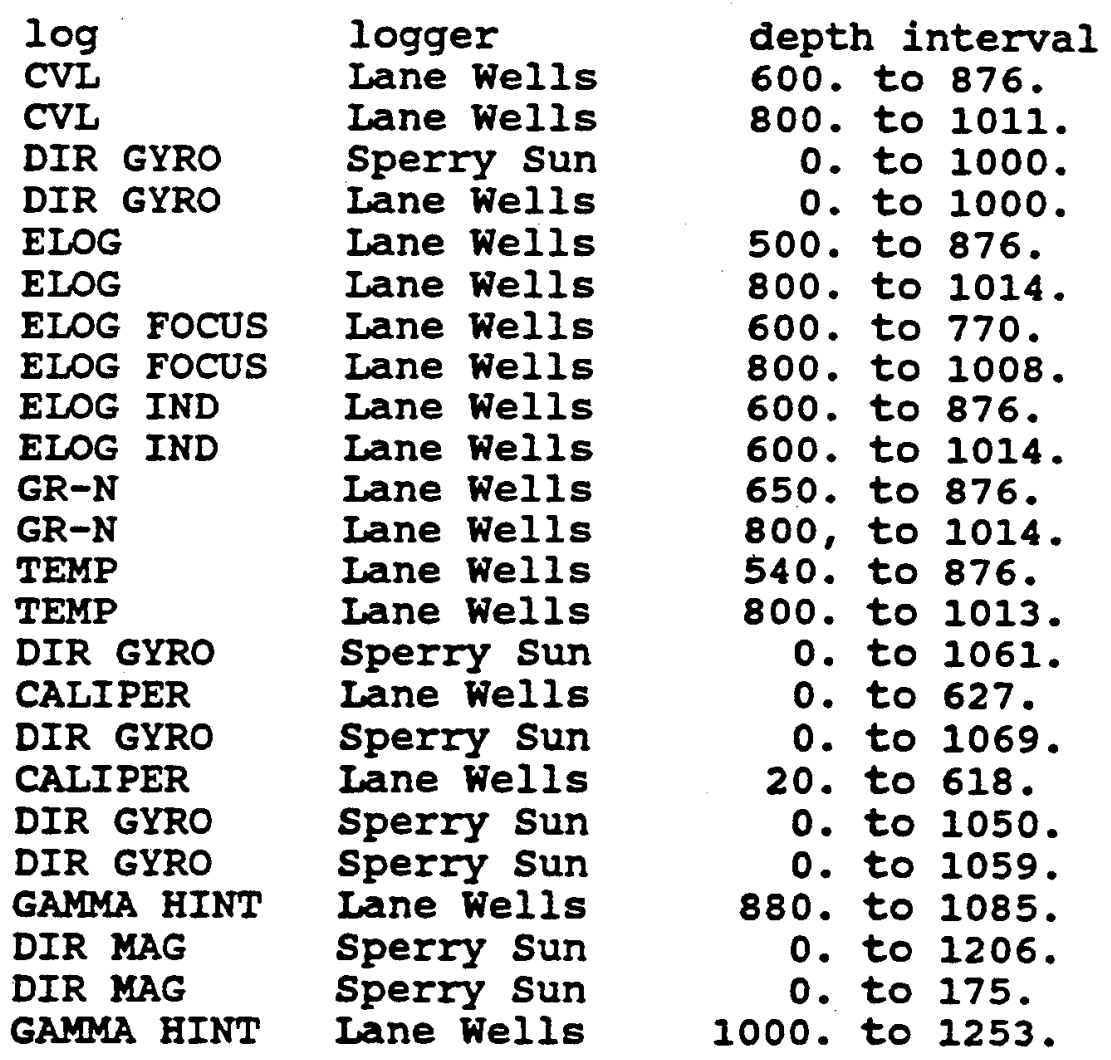




\title{
Appendix D
}

\section{Hole Histories for Holes Drilled for the U3ax Event}

\author{
U-3ax-1 \\ U-3ax-2 \\ U-3ax-3 \\ U-3ax PS \#2 \\ U-3ax PS \#1 \\ U-3ax PS \#1S \\ U-3ax PS \#6
}




\section{HOLMES \& NARVER, INC. \\ WELL HISTORY DATA}

HOLE NUMBER_U-3aX-1

WORK ORDER NUMBER_ $1225-09$

USER.

LOCATION:

LASI,

NTS (Nevada)

TYPE HOLE

County Nye

Aroa 3
$H \& N$ I.D. NUMBER

182436

Sandia Diagnostic Instrument Hole

Surface Elevation 4020.71 ground 4022.86 Coller

RIG SCHEDULE: MOVED ON LOCATION_ $12-76-67$

SPUDDED $\quad 12-19-61$

COMPLETED

$4-7-62$

REMARKS:

USER ACCEPTANCE

$4-7-62$

MUD PROGRAM: Low water loss mud wt. 73 , W.L. 1.8 vix. 52 , P.H. 9, Sand Content 4.5

Air 8751 to 9751 (no record total bbls mud used)

DRILLING EQUIPMENT. Pacilic \#4 Ideco H-30 (0 to 815:)

Lohmann if 25 (Franks Mod. If 658) ( $815^{\prime}$ to 915')

\begin{tabular}{|c|c|c|c|c|c|c|c|c|c|}
\hline \multicolumn{3}{|c|}{ BORE HOLE RECORD } & \multicolumn{6}{|c|}{ CASING RECORD } & \multirow[b]{2}{*}{$\begin{array}{l}\text { SACKS } \\
\text { CEMENT }\end{array}$} \\
\hline FROM & TO & $S I Z E$ & SIZE & WEIGHT & GRADE & COUPLING & FROM & To & \\
\hline 0 & 60 & 26 & $20^{\prime \prime}$ & $32 \pi$ & Conductop & Pipe & 0 & 60 & 100 \\
\hline 60 & 8151 & $15^{\prime \prime}$ & $10-3 / 4^{11}$ & 40.5 & $J-55$ & $\mathrm{WCC}$ & 0 & 813 & 396 \\
\hline 825 & $924 !$ & $9-5 / 8^{11}$ & & & & & & & \\
\hline & & & & & & & & & \\
\hline & & & & & & & & & \\
\hline
\end{tabular}

TOTAL OEPTH

WORKING POINT

$924^{\prime}$

PLUGS

None

JUNK

LOGGING DATA Lane Wellis Caliper 60' to 815' - Sperry Sun survey to 915'.

DEVIATION DATA: M.D. $924^{\circ} \quad$ V.D. $\quad 924^{\prime} \quad$ REFERENCE Sur 247 (6.LO

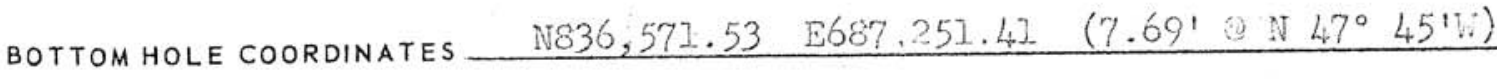
CORING HISTORY No cores taken 
WELI HISTORY

$\mathrm{U}-3 \mathrm{ax}-1$

12/16/61 Moving rig to location.

12/17/61 Moving rig to location.

12/18/61 Rigging up.

12/19/61 Completed rigging up, spudded and drilled $26^{\prime \prime}$ hole to $60^{\prime}$. Ran $20^{\prime \prime}$ casing to $60^{\prime}$ and waited on cementerm.

12/20/61. Cemented $20^{\prime \prime}$ casing $60^{\prime}$ with $110 \mathrm{cu}$. ft. cement. Cement retumed to surface. Drilled $1^{\prime \prime}$ hole from $60^{\prime}$ to $263^{\prime}$.

12/21/61 Drilled 15" hole from 263' to $49^{\prime \prime}$.

$22 / 22 / 61$ Drilled 15' hole from $491^{\prime}$ to $705^{\prime}$.

12/23/61 Drilled 15" hole from $705^{\prime}$ to $730^{\prime}$. Secured ris.

12/24/61 Secured rig.

12/25/61 Secured rig.

12/26/61 Secured rig to 11:30. Drilled 15" hole from 730' to 783'.

$12 / 27 / 61$ Drilled $15^{\prime \prime}$ hole from $783^{\prime}$ to $815^{\prime}$. Ran Lane Wells Caliper log. Ran 10-3/4" casing with shoe $813^{\prime}$ and cemented $900 \mathrm{cu}$. . .t. of cement with $2 \%$ gel and $2 \% \mathrm{CaCl}$.

Cut off casing and rigged dow.

$12 / 28 / 61$ Hoved rig off and suspended hole.

$12 / 26 / 51$ to $4 / 6 / 62$ Hole suspended.

$1 / 6 / 63$ coved in, sigued up.

4/7/62 Blew water out of hole and drilled cement with 9-5/8" bit. Drilled 9-5/8" hole to $915^{\prime}$. Ran Sperry Sun survey.

Risged down, moved off, hole completed. 


\section{HOLMES \& NARVER, INC. \\ WELL HISTORY DATA}

HOLE NUMBER U-3aX-2

WORK ORDER NUMBER $1225-09$

H \& N I.D. NUMBER $\quad 182436$

E.D.S. NUMBer M-508

USER__ LASL

TYPE HOLE_ Sandia Diagnostic Hole

LOCATION:_NTS (NeVada)

County NYE

Area 3

Coordinates N836,575.26 $.687,257.31$ Surface Elevation 4022.69 Col1ar 4020.6 ground

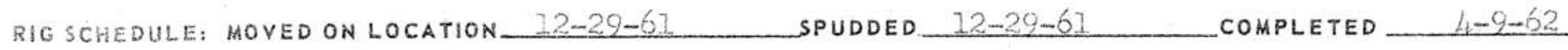

REMARKS:_Hole Suspended 1-7-62 to 4-8-62 USER ACCEPTANCE__ 4-9-6́2

MUD PROGRAM: Low water Loss mud wt. 74 Visc. 62, W.L. 1.5 sand content5\%.

Air 814 to 215 (No record total bbls. mud used)

DRILLING EQUIPMENT. PaCific 4 (Ideco H-30) 0 . to $814^{\prime}$

Lohmann it25 (Franks Mod $\# 658$ ) 814' to $915^{\prime}$.

\begin{tabular}{|c|c|c|c|c|c|c|c|c|c|}
\hline \multicolumn{3}{|c|}{ BORE HOLE RECORD } & \multicolumn{6}{|c|}{ CASING RECORD } & \multirow[b]{2}{*}{$\begin{array}{l}\text { SACKS } \\
\text { CEMENT }\end{array}$} \\
\hline FROM & TO & SIZE & SIZE & WEIGHT & GRADE & COUPLING & FROM & TO & \\
\hline 0 & $50^{\prime}$ & $26^{11}$ & 20 & $32 \pi$ & Conducto: & - Pipe & 0 & 50 & 35 \\
\hline 50 & $81 / 4^{1}$ & $75^{11}$ & $10-3 / 4^{11}$ & 40.54 & $J-55$ & $\mathrm{TEC}$ & 0 & $814 !$ & 375 \\
\hline Q] $\leq \mathrm{h}^{?}$ & $2.5^{1}$ & $9-5 / 8^{\prime \prime}$ & & & & & & & \\
\hline & & & & & & & & & \\
\hline & & & & & & & & & \\
\hline
\end{tabular}

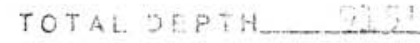

WORKING POINT

9251

PLUGS

none

JUNK

LOGGING DATA Lane Wells Caliper Log 50' to 81.4', Sperry Sun directional Survey (0-915')

DEVIATION DATA: M.D. 915 R.D._915 REFERENCE SUR 252

BOTTOM HOLE COORDINATES N836,574.52 E.687,254.30 (3.10' S76. $\left.11^{\circ} 1^{1} \mathrm{~W}\right)$

CORING HISTORY_NO NO CORES taken 


\section{WELI HISTORY \\ $\mathrm{U}-3 \mathrm{ax}-2$}

12/29/61 Moved in, rigged up, spudded and drilled 26" hole to $50^{\prime}$. Ran $60^{\prime}$ of $20^{\prime \prime}$ casing 32 it and set at $50^{\prime}$.

$12 / 30 / 61$ Cemented $20 "$ with $100 \mathrm{cu}$. ft. with $2 \%$ gel and $2 \% \mathrm{CaCl}_{2}$. Drilled $15^{\prime \prime}$ hole from $50^{\prime}$ to $188^{\prime}$. Secured rig at 2100 for AEC.

12/30/61 Rig secured by AEC from 12-30-61 to 1-2-62.

to

$1-2-62$

$1 / 2 / 62$

$3 / 3 / 62$

$1 / 4 / 62$

$1 / 5 / 62$

$2 / 6 / 62$

$4 / 9 / 62$
Rig secured to 0800 .

Started up and deilled $15^{\prime \prime}$ hole from 188: to $317^{\prime}$.

Drilled $15^{\prime \prime}$ hole from $317^{\prime}$ to $515^{\circ}$.

Drilled $15^{\prime \prime}$ hole from $515^{\prime}$ to $691^{\prime}$.

Drilled 15" hole frorn 691' to 814'. Ban Lane Wells Caliper

$\log \left(50^{\prime}\right.$ to $814^{\prime}$ ).

Rigged up and started muning casing.

Ran 10-3/4" casing 40.5\# and set shoe at 814,' Cemented casing with $1000 \mathrm{cu}$. ft. cement using $2 \% \mathrm{Gel}$ and $2 \% \mathrm{CaCl}_{2}$.

Cut off casing, rigged down, moved rig ofi.

Hole suspended from $1 / 7 / 62$ to $4 / 8 / 62$.

Rigsed up, blew hole dry and drilled cement and shoe with 9-5/8" bit. Drilled $9-5 / 8^{\prime \prime}$ hole from $814^{\prime}$ to $915^{\prime}$.

Ran Sperry Sun directiona.1 survey $\left(0-915^{\prime}\right)$

Rieged down, moved off, hole completed. 
HOLMES \& NARVER, INC.

WELL HISTORY DATA

HOLE NUMBER U-3eX-3

WORK ORDER NUMBER_ 1225-09 H\& N I.O. NUMBER 182436

E.d.s. Number M-508

USER__ WASL TYPE HOLF Sandia Diagnostic Hole

LOCATION

Nevada (NTS)

County Nye

3 Coordinates N836.587.86 \$6887.257.10 Surface Elovation 4023.21 Collar, 4021.1 G. I.

RIG SCHEDULE: MOVED ON LOCATION_ 12-19-61

Hole suspended, $12-23-61$ to $12-26-61$.

REMARKS: Hole sUspended, $12-28-61$ te $4-10-62$.

$12-19-61$

COMPLETED

$4-11-62$

MUD PROGRAM. Low water loss mud. (No record total bbls. mud used.)

Air, 801 ' to 915 '.

DRILLING EQUIPMENT Termina? 5 (Ideco I-40) Ised from O' to 801 .

Lohmann \#25 (Franks Model 3 Bxplorer) Used from 801' to $915^{\prime}$.

BORE HOIE RECORD
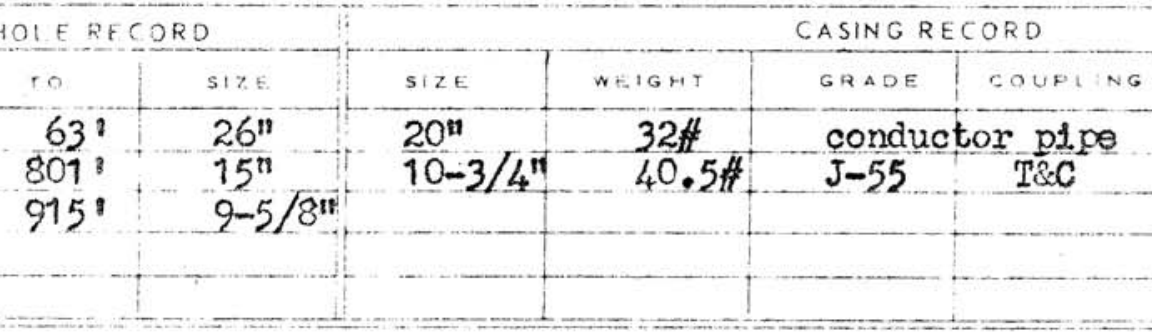

CASING RECORD

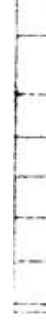

\begin{tabular}{|r|r}
\hline \multicolumn{2}{|c|}{ BORE HOIE RE } \\
\hline 0 ROM & $63^{\circ}$ \\
\hline 63 & $801^{\circ}$ \\
\hline 801 & $915^{\circ}$ \\
\hline & \\
\hline
\end{tabular}

TOTAL DEPTH_..... $915^{\prime}$

WORKING POINT

$915^{\prime}$

PLUGS None

None

LOGGING DATA Iane Wells collper log $\left(63^{\prime}-301^{\prime}\right)$

Sperry Sun directional survey (0'-915')

DEVIATION DATA: M.D.

$915^{\prime}$

$915^{\prime}$

REFERENCE,SUR 257 (G.Ten)

BOTTOM HOLE COORDINATES

$\mathrm{N} 336.591 .28 \quad \mathrm{E} 687,260.38 \quad\left(4.74, \mathrm{~N} / 3^{\circ} 48^{\prime} \mathrm{g}\right)$ 


\section{IEIL HI ORY \\ $\mathrm{u}-3 \mathrm{ax}-3$}

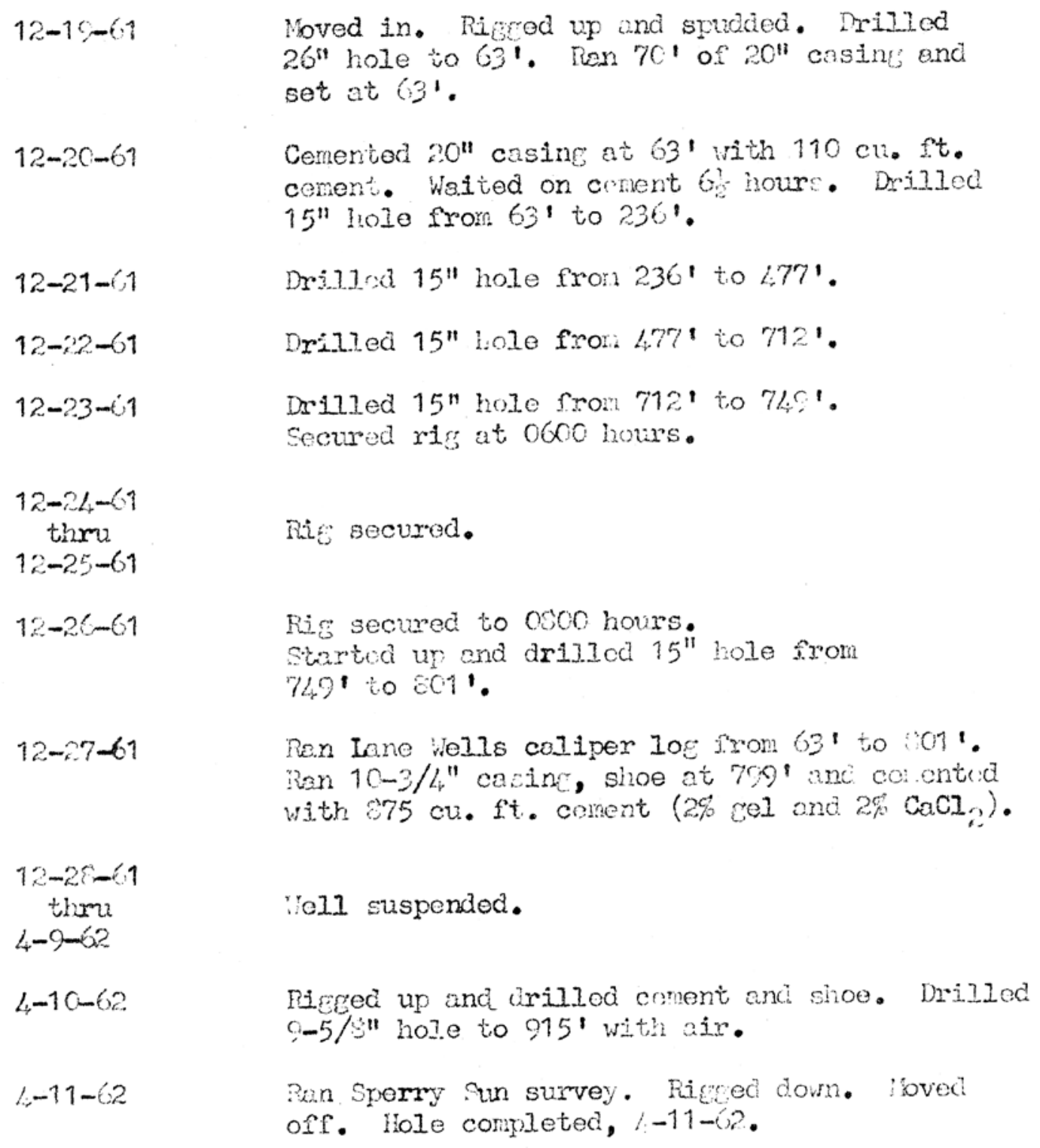


HOLMES \& NARVER, INC.

WELL HISTORY DATA

HOLE NUMBER U-3ax PS \# 2

WORK ORDER NUMBER_ $1213-86$

H \& N I.D. NUMBER 182084

E.D.S. NUMBER M-508

USER LASL TYPE HOLE Post Shot

LOCATION:_NTS (Nevada) County Nye Coordinates N836,568.59 . $1687,267.19$ Surface Elevation 3978.4 Grnd., 3978.12 Csg.

RIG SCHEDULE: MOVED ON LOCATION $5-8-62$ SPUDDED $\quad 5-8-62$ COMPLETED $\quad 5-9-62$ REMARKS: USER ACCEPTANCE — -

MUd PROGRAM: Plant mud, gel base, 58 to 68 sec. 72\# Driscose and Soda Ash added. Total mud used -4295 bbls.

DRILLING EQUIPMENT. Carmack (National D-300)

T.

\begin{tabular}{|c|c|c|}
\hline \multicolumn{3}{|c|}{ BORE HOL.E RECORD } \\
\hline FROM & TO & SIZE \\
\hline 0 & $40^{\prime}$ & $24^{\prime \prime}$ \\
\hline $40^{\prime}$ & $975^{\prime}$ & $9-5 / 8^{\prime \prime}$ \\
\hline & & \\
\hline & & \\
\hline & & \\
\hline
\end{tabular}

\begin{tabular}{|c|c|c|c|}
\hline \multicolumn{4}{|c}{ CASING REC } \\
\hline SIZE & WEIGHT & GRADE & \\
\hline $10-3 / 4^{\prime \prime}$ & 40.5 & $\mathrm{~J}-5$ & \\
\hline & & & \\
\hline & & & \\
\hline & & & \\
\hline & & & \\
\hline
\end{tabular}

\begin{tabular}{|c|c|}
\hline COUPLING & \\
\hline ST\&C & \\
\hline & \\
\hline & \\
\hline & \\
\hline
\end{tabular}

FROM

TOTAL DEPTH. $975^{\prime}$ WORKING POINT PLUGS None JUNK None LOGGING DATA Lane Wells gamma probe $300^{\prime}$ to $880^{\prime}$. Sperry Sun magnetic multishot Survey $0^{\prime}$ to $808^{\prime}$.

DEVIATION DATA: M.D. $808.00^{1}$ 808.00 REFERENCE MS-309 BOtTOM HOLE COORDINATES N836,564.91 E $687,260.65$ (7.50' S $60^{\circ} 38 \mathrm{~W}$ ) CORING HISTORY Honco sidewall cores. 23 cores in the interval 8471 to 9101. 
DRIILING HISTORY

$\mathrm{U}-3 \mathrm{ax}$ PS \#2

$5 / 7 / 62 \quad 24 "$ hole was drilled to $40^{\prime}$ with a bucket rig.

5/8/62 10-3/4" O.D. 40.5 " casing was cemented at $40^{\prime}$ with 170 sacks of Gyp-Seal. Drilling equipment (Carmack) was moved in and $9-5 / 8^{\prime \prime}$ hole was drilled to $805^{\prime}$. Circulation was lost while drilling at $540^{\prime}$.

5/9/62 9-5/8" hole was drilled to a total depth of $975^{\prime}$. Lane Wells gamma probe was mun from 300 ' to $880^{\prime}$. Homco eidewall coring tool was mun and 23 samples were taken in the interval $847^{\prime}$ to $910^{\prime}$. Sperry Sun magnetic multishot survey was mun from $0^{\prime}$ to $808^{\prime}$. Drilling equipment was moved out. 
HOLMES \& NARVER, INC.

WELL HISTORY DATA

HOLE NUMBER U-3ax PS \# I

WORK ORDER NUMBER_ $1213-86$

H\&N I.D. NUMBER 182084

E.D.S. NUMBER M-510

USER LASL

TYPEHOLE POst Shot

LOCATION:_ NTS (Nevada) County HJe

Coordinates N836,533.57 E $687,250.09$ Surface Elevation 3978.5 Grmd. 3979.34 Collar

RIG SCHEDULE: MOVED ON LOCATION_5/8/62_SPUDDED 5/8/62_COMPLETED $5 / 16 / 62$

REMARKS:

USER ACCEPTANCE

MUD PROGRAM:

Plant mud/ gel base, 60 to 68 sec. 72ift, with Driscose and Boda Ash added. Total mud used 5225 bbls.

DRILLING EQUIPMENT

Terminal \#10 (Ideco H-35)

\begin{tabular}{|l|c|c|}
\hline \multicolumn{3}{|c|}{ BORE HOL.E RECORD } \\
\hline FROM & TO & SIZE \\
\hline 0 & $40^{\prime}$ & $24^{\prime \prime}$ \\
\hline $40^{\prime}$ & $975^{\prime}$ & $9-5 / 8^{\prime \prime}$ \\
\hline & & \\
\hline & & \\
\hline & & \\
\hline
\end{tabular}

\begin{tabular}{|l|r|}
\hline SIZE & WEIGHT \\
\hline $10-3 / 4^{\circ}$ & 40.5 \\
\hline & \\
\hline & \\
\hline & \\
\hline
\end{tabular}

CASING RECORD

\begin{tabular}{|l|l}
\hline GRADE & COUPLING \\
\hline
\end{tabular}

TOTAL DEPTH

$975^{1}$

WORKING POINT

$-$

PLUGS

None

JUNK_ None

LOGGING DATA

Lane Wells gammia probe $770^{\prime}$ to $939^{\prime}$. Sperry Sun magnetic multishot $0^{\prime}$ to $915^{\prime}$.

DEVIATION DATA: M.D.

$915^{\prime} .00$

v.D. $914.92^{\prime}$

REFERENCE

MS-328

BOTTOM HOLE COORDINATES N836,523.81 E $687,239.44$ (14.45 S $47^{\circ} 30 \mathrm{~W}$ )

IARING HISTORY Homce sidewall coras. Total of 10 samples between 880 ' and 8981. 


\section{DRIILING HISTORY}

STN: U-3ex PS\#I

$5 / 7 / 62$

A 24 " hole was drilled to $40^{\prime}$ with a bucket rig.

$5 / 8 / 62$

10-3/4", 40.5" casing was cemented at 40' with 134 sacks of Gyp-Seal. Drilling equipment (Terminal tilo) was roved in and $9-5 / 8^{\prime \prime}$ hole was drilled to $485^{\circ}$.

5/9/62 9-5/8" hole was drilled to $975^{\prime}$ total depth. Circulation was lost while drilling at 568'. Lane Wells garma probe was run from $770^{\prime}$ to $939^{\prime}$. Pipe stuck at $780^{\prime}$ while being pulled.

5/10/62 Drill pipe was worked up to 762 ' where it stuck.

5/11/62 Drill pipe was backed off at 701'. Jars were run and fish was farred up to 687'. Fishing tools were pulled and rig was skidded $10^{\prime}$ east to drill PS \#1S.

5/15/62 Rig was skidded back over the hole and hole was cleaned out to top of fish at 687'. 8-5/8" wash pipe was run and fish was washed over causing it to drop down the hole.

5/16/62 Top of fish was found at $757^{\circ}$ and was recovered. Homco sidewall coring tool was mun and 10 samples were taken in the interval $880^{\prime}$ to $898^{\prime}$. A Sperry Sun magnetic multishot survey was run from 0 to $915^{\prime}$. Drilling equipment was moved out. 
HOLMES \& NARVER, INC.

WELL HISTORY DATA

HOLE NUMBER U-3aX PS \# IS

WORK ORDER NUMBER 1213-86

H \& N I.D. NUMBER 182084

E.D.s. NUMBER $\mathrm{M}-508$

USER IASL

TYPE HOLE_ Post Shot

LOCATION: NTS (NEVADA)

County Nye

Area

3

Coordinates N836,532.09 . $.687,259.79$ Surface Elevation 3978.5 Grnd. 3978.34 Collar

RIG SCHEDULE: MOVED ON LOCATION_ $5 / 11 / 62$

SPUDDED $\quad 5 / 21 / 62$

COMPLETED $\quad 5 / 14 / 62$

REMARKS:

USER ACCEPTANCE

MUD PROGRAM:

Plont mud. Cel base, 60 to 70 soe., 70 fl, Driscose and Soda Ash added.

Tatel mad us $6200 \mathrm{bbls}$.

DRILLING EQUIPMENT.

Terminal \#10 (Ideco $\mathrm{H}-35$ )

\begin{tabular}{|c|c|c|}
\hline \multicolumn{3}{|c|}{ BORE HOLE RECORD } \\
\hline FROM & TO & SIZE \\
\hline 0 & $40^{\prime}$ & $15^{\prime \prime}$ \\
\hline $40^{\prime}$ & $945^{\prime}$ & $9-5 / 8^{\prime \prime}$ \\
\hline & & \\
\hline & & \\
\hline & & \\
\hline
\end{tabular}

\begin{tabular}{|c|c|c|c|c|c|c|}
\hline \multicolumn{7}{|c|}{ CASING RECORD } \\
\hline SIZE & WEIGHT & GRADE & COUPLING & FROM & TO & $\begin{array}{c}\text { SACKS } \\
\text { CEMENT }\end{array}$ \\
\hline $10-3 / 4$ & 40.5 & $J-5$ & STEC & 0 & 40 & 37 G/F \\
\hline & & & & & & GaI SQRI \\
\hline & & & & & & \\
\hline & & & & & & \\
\hline & & & & & & \\
\hline
\end{tabular}

TOTAL DEPTH_ $945^{\prime}$

WORKING POINT

PLUGS

none

JUNK_ None

LOGGING DATA

Iane Wells gamma probe $750^{\prime}$ to $920^{\prime}$. Speryy Sun magnotic mult ishot survey $0^{\prime}$ to 900 '.

DEVIATION DATA: M.D. $900 \% .00$

V.D. $899.98^{\prime}$

REFERENCE MS-321

вотTOM HOLE COORDINATES N 836,536.71 E687, 253.12 (8.31' O N $55^{\circ} 17^{\prime}$ 'W)

CORING HISTORY Homco sidewall cores. 26 samples in the interval 867 ' to 901 '. 


\section{DRIIIING HISTORY}

U-3ex. PS \# IS

5/11/62 Drilling Equipment (Terminal \#10) was skidded from PS \#I and 15" hole was drilled to $40^{\prime}$.

5/12/62 10-3/4: 0.D. 40.5\# casing was cemented at $40^{\prime}$ with 37 cu. ft. of Cal-seal. 9-5/8" hole was drilled to $280^{\prime}$.

$5 / 13 / 629-5 / 8^{\prime \prime}$ hole was drilled to a total depth of $945^{\prime}$. Circulation was lost while drilling at $569^{\prime}$.

$5 / 14 / 62$ Lane Wells gamme probe was mun from $750^{\prime}$ to $920^{\prime}$

Homco sidewall coring tool was mun and 26 samples were taken in the interval $867 '$ to 901'. A Sperry Sun Magnetic Multishot survey was run from $0^{\prime}$ to $900^{\prime}$. Drilling equipment was moved out. 
HOLMES \& NARVER, INC.

WELL HISTORY DATA

HOLE NUMBER U-3aX PS\# 6

WORK ORDER NUMBER_ $1213-91$

H \& N I.D. NUMBER 182085

E.D.S. NUMBER M-627

USER LASL TYPE HOLE

Post Shot

LOCATION:_ NTS (Nevada)

County Nye

Aroo 3

Coordinates N836,631.17 E 687,561.49 Surface Elevation 4022.3 Grnd, 4022.45 Collar

RIG SCHEDULE: MOVED ON LOCATION_ $5 / 6 / 62$

SPUDDED $5 / 6 / 62$

COMPLETED $\quad 5 / 10 / 62$

REMARKS:

USER ACCEPTANCE - -

MUd PRogram: Plant mud. Gel base, 60 to 70 sece, 70\#, Driscose and Soda Ash added.

Total mud used -4340 barrels.

DRILLING EQUIPMENT.

Boyles slant rig

\begin{tabular}{|c|c|c|c|c|c|c|c|c|c|}
\hline \multicolumn{3}{|c|}{ BORE HOL.E RECORD } & \multicolumn{7}{|c|}{ CASING RECORD } \\
\hline FROM & TO & SIZE & SIZE & WEIGHT & GRADE & COUPLING & FROM & TO & $\begin{array}{l}\text { SACKS } \\
\text { CEMENT }\end{array}$ \\
\hline 0 & 601 & $9-5 / 8^{\prime \prime}$ & $7^{\prime \prime}$ & 23 & $J-5$ & STEC & 0 & 40 & - \\
\hline 401 & $1086.8^{1}$ & $6-1 / 4^{11}$ & & & & & & & \\
\hline & & & & & & & & & \\
\hline & & & & & & & & & \\
\hline & & & & & & & & & \\
\hline
\end{tabular}

TOTAL DEPTH_ $1086.8^{\prime}$

WORKING POINT

PLUGS none

JUNK Nono

LOGGING DATA Lane Wells temperature $\log 820^{\prime}$ to $1040^{\prime}$. Lane Wells ganma probe $800^{\prime}$ to $1085^{\prime}$. Sperry Sun magnetic multishot survey $40^{\prime}$ to $1086^{\prime}$.

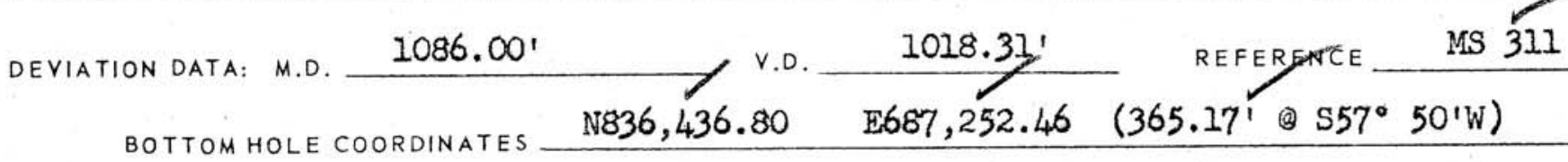
IRING HISTORY Homeo sidewall cores. 17 samples in the interval 892' to 982 '. 


\section{WELL HISTORY}

I- $-3 a x$ PS it 6

5/6/62 Boyles slant rig was moved in and $9-5 / 8^{\prime \prime}$ hole was drilled to $40^{\prime}$. 7: O.D. 23:" casing was cemented at $40^{\prime}$. 踏 wes moved out for shot.

5/7/62 Rig was moved back in and 6-1/4 hole was drilled to $153^{\prime}$.

5/8/62 6-1/4" hole was drilled to 1016.8'. Circulation was lost while drilling at 212'.

5/9/62 6-1/4:" hole was drilled to a total depth of $1086.8^{\prime}$.

Iane $V^{\prime e l l s}$ temperature log was mun from $820^{\prime}$ to $1040^{\prime}$. Iane Wells ganma probe was run from 800' to 1085'. Homco sidewall coring tool was mu and 17 samples were taken in the interval $892^{\prime}$ to $982^{\prime}$.

5/10/62 Sperry Sun megnetic sultishot survey was run from $40^{\prime}$ to $1086^{\prime}$. Drilling equipment was moved out. 


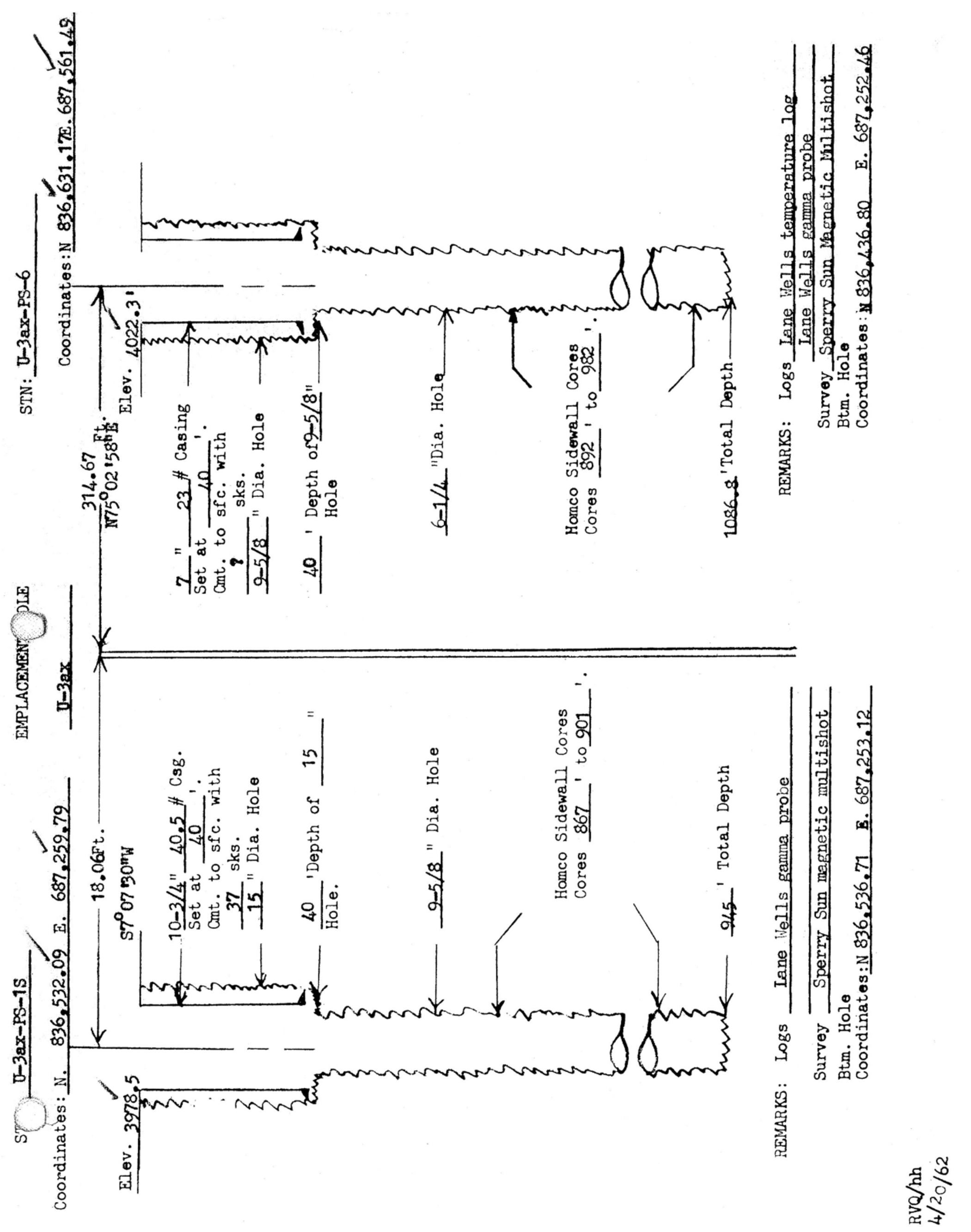




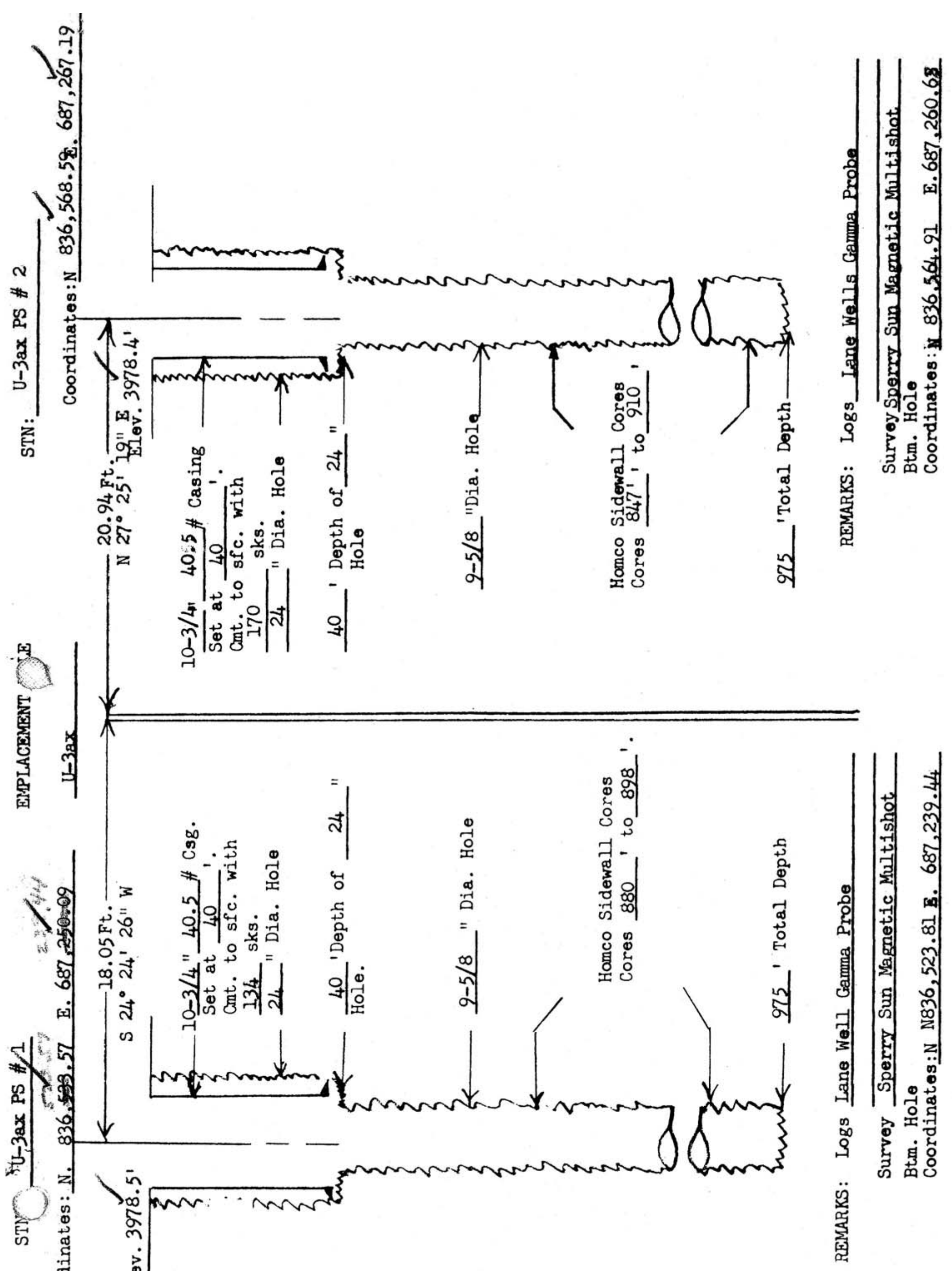




\section{Appendix E}

\section{Hole Histories for Holes Drilled for the U3bl Event}

U-3bl-1

$\mathrm{U}-3 \mathrm{bl}-2$

U-3bl-3S

$\mathrm{U}-3 \mathrm{bl}-3$

U-3bl PS \#1

U-3bl PS\#2 


\section{HOLMES \& NARVER INC.. WELL HISTORY DATA \\ A. NUMBER U U-3al-1 \\ BNVISED WELL HISTORY}

WORK ORDER NUMBER I I215-29

HEN I.D. NUMBER __ 182751

E.D.S. NUMBER

USER

IASI TYPE HOLE Instmurant.

LOCATION NeVEds (H.T.S.) County Nye $\triangle R E A \quad 3$

Surface Coordinates $18836,423.56 \quad \$ 687,600.50$ Ground Elevation 4021.01

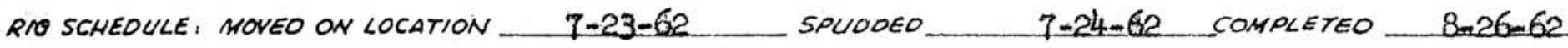
REMARKS Hole iale Iron 7-27-62 to 8-26-62 Incl.

CIRCULATING MEOIA AII AIr

NO OF COMPRESSORS \& SIZE

ORILLING EQUPPMENT. Bucket rig to set conductor, Nattoxal T-20 to cementing of 10-3/4" Csg. Idece $\mathrm{H}-35$ to dxill $9-5 / 8$ " hole.

\begin{tabular}{|c|c|c|c|c|c|c|c|c|c|c|}
\hline \multicolumn{3}{|c|}{ IE HOLE RECORO } & \multicolumn{8}{|c|}{ CASING RECORD } \\
\hline$M$ & 70 & SIZE & 1.0. & $W T / F T$ & WALL THICN. & GRAOE & COLIPLINO & FROM & To & $\begin{array}{l}\text { CU.ET } \\
\text { CEMENT }\end{array}$ \\
\hline $0^{\prime}$ & $40^{\prime}$ & $26 "$ & $18^{\prime \prime}$ & Condus & tion & & & 0 : & $40:$ & 110 en fi \\
\hline $40^{\circ}$ & $480^{\circ}$ & $15^{\prime \prime}$ & $10-3 / 4 "$ & $40.5 \#$ & & $J-55$ & $\mathrm{ST} \& \mathrm{C}$ & $0^{\prime}$ & 4801 & 696 \\
\hline 4801 & $720^{\circ}$ & $9-5 / 8$ & & & & & & & & \\
\hline & & & & & & & & & & \\
\hline
\end{tabular}

TOTAL OEPTH__ T2O MANDREL DEPTH PLUGS

JUNK

LOGGING DATA. Sperry Sun Gyoscopic Wultishot from surface to 712 .

DEVIATION DATA W.D.

$712^{\prime}$

V.O.

REFERENCE SUR 419

HOLECOOROINATES@_. H836,421.99 $3687,604.22$

REVISION March 2, 1963

DATE Marci 9, 1963 
Well History

Stn. $U-3 b l-1$

6-11-62 Moved in bucket rig and drill 26" hole to 40'. Cemented 18" casing to surface with $110 \mathrm{cu}$ ft. of cement \& moved off.

7-23-62 Moved in National T-20 rig, worked on mast and rigged up.

7-24-62 Spudded in and drilled 15' hole to 77', using air as a drilling media.

7-25-62 Drilled 15' hole from 77' to 480 '. Conditioned hole to mun casing. Ran and cemented new $103 / 4 "-40.5 \mathrm{H}$, J- 55 ST\&C casing at 480 with $480 \mathrm{cu}$ ft. of cement pretreated with $15 \#$ cu ft. gilsonite, $1 \% \mathrm{Halad}-9,2 \% \mathrm{CaCl}_{2}$ \& $12 \%$ gel. Cement did not surface. Pumped in $216 \mathrm{cu} \mathrm{ft}$. of neat cement in the annulus.

7-26-62 Stood cemented 12 hours. Landed $103 / 4^{\prime \prime}$ casing and suspended the well 7-26-62. Rigged down and moved off.

8-26-62 Moved in Ideco $\mathrm{H}-35$ \& rigged up. Ran in with $95 / 8 \mathrm{~m}$ bit and blew the hole dry in stages. Drilled $95 / 3{ }^{\prime \prime}$ hole from $480^{\prime}$ to $720^{\prime}$. Conditioned hole and ran Sperry Sun Gyroscopic Multishot from surface to 707'. Measured in with drill pipe and bit, found top of f111-0712'. Cleaned out from 712 ' to $720^{\prime}$. Blew hole clean. Pulled out of hole and laid down drill plpe. Hole completed. 
HOLMES $\&$ NARVER INC.

WELL HISTORY DATA

REVISED WESL HISTORY

HUL NUMBER U-3bI-2

WORK ORDER NUMBER 1215-29

HEंN 1.0. NUMBER _. 182751

E.D.S. NUMBER

USER

IASI

TYPE HOLE

Instrument

LOCATION

Nevada (NMS)

County - Nye

$\triangle R E A$

3

Surfoce Coordinates $\$ 1836,435.22$ W687,599.42 Ground Elavation 4021. Q'

RIO SCHEDULE: HOVEO ON LOCATION -6-13-62 SPLODEO

$6-13-62$ COMPLETEO

$8-3-62$

REMARKS

Hole suspended 6-14-62 to 8-2-62

CIRCULATING MEOIA

Air

NO OF COMPRESSORS \& SIZE

ORILLING EQUIPMENT. Bucket $r$ Ig to drill conductor, National I-20 for balance of hole.

\begin{tabular}{l}
\hline \multicolumn{4}{|c|}{ PE HOLE RECORO } \\
\begin{tabular}{r|r|l}
\hline$M$ & $T O$ & SIZE \\
\hline $0^{\prime}$ & $40^{\prime}$ & $26^{\prime \prime}$ \\
\hline $40^{\prime}$ & $480^{\prime}$ & $15^{\prime \prime}$ \\
\hline $480^{\prime}$ & $720^{\prime}$ & \\
\hline & & \\
\hline & & \\
\hline
\end{tabular}
\end{tabular}

\begin{tabular}{|l|}
\hline 1.0 \\
\hline $18^{\prime \prime}$ \\
$10-3 / 4^{\prime \prime}$ \\
\hline \\
\hline
\end{tabular}

\begin{tabular}{|c|c|}
\hline Cr/Fr & waLG THICK. \\
\hline Condudtor \\
\hline 40.5 & \\
\hline & \\
\hline & \\
\hline
\end{tabular}

CASING RECORD

TOTAL OEPTH

$720^{\circ}$

MANOREL DEPTH

PLUGS

SUNK

LOGGING DATA. Sperry Sun Gyroscopic Multishot Survey Inom surface to T25'.

DEVIATION DATA M.D. T25'

HOLECOOROINATES@

CORING HISTORY
V.D.

$17836,434.08$

$725^{\prime}$

REFERENCE SUR 420

REVISION

March 9, 1963

DATE March 9, 1963

WRITTEN BY

CHECKEO BY 
Well. History

Stn. U-3bl-2

6-11-62 Moved in bucket rig and drilled 26" hole to 40'. Cemented 18" casing at $40^{\prime}$ with $110 \mathrm{cu} \mathrm{ft}$. of cement. Moved out.

6-13-62 Moved in National T-20 is rigged up. Spudded in and drilled 15" hole to 480 ' using air as a drilling media.

6-14-62 Ran and cemented $103 / 4^{\prime \prime}-140.5 \#, J-55$, ST\&C casing at 480 ', cemented through Baker guide shoe with $580 \mathrm{cu} f t$. of cement pre-mixed with $2 \%$ hydrated gel., 15\# cu ft. gilsonite, 1\% Halad9 \& 2\% $\mathrm{CaCl}_{2}$. Full cement returns at surface and then fell away. Stood cemented 4 hours. Filled annulus with $7.75 \mathrm{cu} \mathrm{ft}$. of neat cement. Cut off casing. Well? suspended this date.

8-2-62 Moved in National T-20 \& rigged up. Ran in with $97 / 8$ " bit and located top of cement at 347'. Drilled out cenent and shoe and made $97 / 8 "$ hole to 6181 .

8-3-62 Drilled 9 7/8' hole from 618' to 720'. Conditioned hole to mun Sperry Sun. Ran Sperry Sun Grroscojic Multi shot Survey from surface to 7251 . Measured in with drill pipe to 720.29!. Laid down drill pipe and hole completed this date. 
HOLMES \& NARVER, INC.

WELL HISTORY DATA

HOLE NUMBER U-3BI-3S

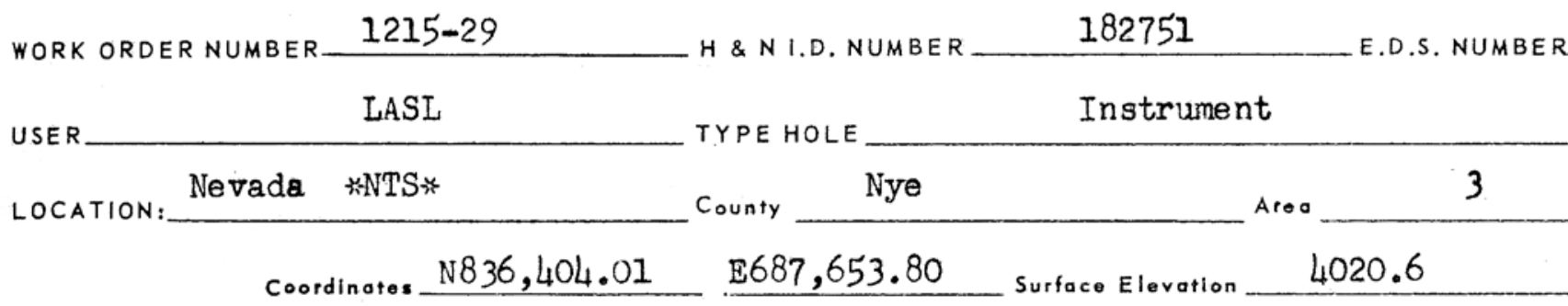

RIG SCHEDULE: MOVED ON LOCATION_ 8-10-62 SPUDDED 8-10-62 COMPLETED $\frac{8-16-62}{8-16-62}$

REMARKS:

USER ACCEPTANCE

MUD PROGRAM: Air to T.D. and clay base mud to complete.

DRILLING EQUIPMENT.

National T-20

\begin{tabular}{|c|c|c|c|c|c|c|c|c|c|}
\hline \multicolumn{3}{|c|}{ BORE HOLE RECORD } & \multicolumn{7}{|c|}{ CASING RECORD } \\
\hline FROM & то & SIZE & SIZE & WEIGHT & GRADE & COUPLING & FROM & TO & $\begin{array}{l}\text { SACKS } \\
\text { CEMENT }\end{array}$ \\
\hline 01 & $40^{\prime}$ & $26 "$ & $18^{\prime \prime}$ & Surface & & & 01 & $40^{\prime}$ & $100 \mathrm{cu} \mathrm{ft}$ \\
\hline 401 & 4801 & 151 & $103 / 4 "$ & $40.5 \#$ & $J-55$ & ST\&C & $0^{\prime}$ & 4801 & $785 \mathrm{cu} \mathrm{ft}$ \\
\hline & & & & & & & & & \\
\hline & & & & & & & & & \\
\hline
\end{tabular}

TOTAL DEPTH NORKING POINT

PLUGS Fill $770^{\prime}$ to $682^{\prime}$

LOGGING DATA

Sperry Sun Multishot and Gyroscopic surveys to $715^{\circ}$.

DEVIATION DATA: M.D. $715^{\prime}$

V.D.

$715^{\prime}$

REFERENCE SUR-427 MS -428

BOtTOM HOLE COORDINATES N N836,404.01, E687652.47 
Well History

Stn. $\mathrm{U}-3 \mathrm{~b} 1-3 \mathrm{~S}$

8-9-62 Moved in Portadrill and drilled 40' of 26" hole. Ran and cemented 18" casing at $40^{\prime}$ with $100 \mathrm{cu}$ ft. cement with $2 \% \mathrm{CaCl}_{2}$. Moved out Portadrill.

8-10-62 Moved in National T-20 and rigged up. Drilled out shoe and made 15" hole to $480^{\prime}$ using air as a circulating media. Conditioned hole for casing. Ran and cemented new $103 / 4 "$, 40.54, J-55, ST\&C casing at 480 ' with $480 \mathrm{cu} \mathrm{ft}$. cement with $2 \%$ gel, $15 \# \mathrm{cu} \mathrm{ft}$. gilsonite, $1 \%$ Halad 9 and $2 \% \mathrm{CaCl}_{2}$. Stood cemented. Cemented annulus with $305 \mathrm{cu}$ ft. of cement with $I=1$ perlite \& $2 \% \mathrm{CaCl}_{2}$.

8-11-62 Stood cemented 12 hours. Landed $103 / 4 "$ casing. Drilled out shoe and made $95 / 8 "$ hole to $712^{\prime}$. Hole started sloughling while drilling @ $712^{\prime}$, plugged bit while making a connection. Pulled out and unplugged bit. Hit fill at 624'. Cleaned out to 640'.

8-12-62 Blew hole open to 675', unable to make a connection, hole filled to $640^{\prime}$. With open end drill pipe hung at $638^{\prime}$ pumped in $150 \mathrm{cu} \mathrm{ft}$. of cement with $2 \% \mathrm{CaCl}_{2}$. Pulled up to $480^{\prime}$ and pumped in $98 \mathrm{cu} \mathrm{ft}$. cement. Stood cemented 4 hours. Ran in and located top of cement at 547'. Made trip to unplug bit. Cleaned out from $480^{\prime}$ to 547'. Cleaned out $95 / 8$ ' hole from 547' to 646', hard cement (a) 616'. With open end drill pipe hung at 614' pumped in $150 \mathrm{cu} \mathrm{ft}$. of cement with $2 \% \mathrm{CaCl}_{2}$. Stood cemented 4 hours. Top of fill 608'. Cleaned out from 599'.

8-13-62 Cleaned out to 649' with open end drill pipe hung at 615' pumped in 300 $\mathrm{cu} \mathrm{ft}$. of cement with $12 \# \mathrm{cu}$ ft. gilsonite with $2 \%$ gel and $2 \% \mathrm{HA}-5$. W.O.C. 4 hours. Located top of cement at 546', cleaned out with $95 / 8$ " bit to 584'. Heavy sand returns and sloughing. Received orders to change from air to mud. Cleaned out with mud, returns a) $650^{\prime}$.

8-14-62 Cleaned out to $712^{\prime}$ and drilled $95 / 3^{\prime \prime}$ hole to $770^{\prime}$. Hole tight at $730^{\prime}$. Bailed hole to $600^{\prime}$.

8-15-62 Bailed hole to 715'. Ran Sperry Sun gyroscopic survey to 500' and Magnetic survey to $715^{\prime}$. Bailed at rate of $10 \mathrm{Bbls} /$ hour.

8-16-62 Bailed hole dry to 682'. Hole filled in below this point. Hole completed 8-16-62. Rigged down and moved off. 
HOLE NUMBER U-3bl-3

WORK ORDER NUMBER 1215-29

USER LASL

LOCATION: Nevada - N.T.S.
H \& N I.D. NUMBER 182751

E.D.S. NUMBER

Ins trument

TYPE HOLE

Nye

Area 3

Surface Elovation
4021.0

Coordinates N836,453.27 $\quad 6687,600.37$

Abandoned COMPLETED

RIG SCHEDULE: MOVED ON LOCATION_6-12-62 SPUDDED 6-12-62 USER ACCEPTANCE REMARKS: Hole idle 6-14-62 thru 8-2-62 and on 8-10-62 MUD PROGRAM: Air

DRILLING EQUIPMENT. Ideco $\mathrm{H}-35$ to $680^{\prime}$ (pulled in mast)

National $\mathrm{T}-20$ to finish.

\begin{tabular}{|c|c|c|}
\hline \multicolumn{3}{|c||}{ BORE HOLE RECORD } \\
\hline FROM & TO & SIZE \\
\hline$O^{\prime}$ & $40^{\prime}$ & $26^{\prime \prime}$ \\
\hline $40^{\prime}$ & $40^{\prime}$ & $15^{\prime \prime}$ \\
\hline $480^{\prime}$ & $720^{\prime}$ & $95 / 8^{\prime \prime}$ \\
\hline & & \\
\hline & & \\
\hline
\end{tabular}

\begin{tabular}{|c|c|c|c|c|c|c|}
\hline \multicolumn{7}{|c|}{ CASING RECORD } \\
\hline SIZE & WEIGHT & GRADE & COUPLING & FROM & To & $\begin{array}{l}\text { SACKS } \\
\text { CEMENT }\end{array}$ \\
\hline $18^{n}$ & Surface & Plpe & & 01 & 401 & 50 cu. \\
\hline $103 / 4 "$ & $40.5 \#$ & J-55 & ST\&C & 01 & 4801 & $505 \mathrm{cu}$ \\
\hline & & & & & & 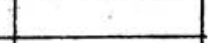 \\
\hline & & & & & & \\
\hline & & & & & & \\
\hline
\end{tabular}

TOTAL DEPTH $720^{\prime}$ WORKING POINT PLUGS $\frac{720^{\prime} \text { to } 519^{\prime}}{\& 48^{\prime} \text { to surface. }}$ JUNK None LOGGING DATA None

DEVIATION DATA: M.D.

V.D. REFERENCE BOTTOM HOLE COORDINATES CORING HISTORY None taken. 
Well History

Stn. U-3bl-3

6-11-62 Moved in bucket rig and drilled 26" hole to 40'. Set and cemented 18" casing (1) 40' with $50 \mathrm{cu}$ ft. Cal-Seal. Moved off.

6-12-62 Moved in Ideco H-35 rig and rigged up. Drilled out shoe and made 15" hole to 300', using air as a drilling media.

6-13-62 Drilled 15" hole from 300' to 480'. Ran and cemented new 10 3/4", 40.5\# casing at $480^{\prime}$ with $580 \mathrm{cu}$ ft. cement permixed with $2 \%$ ge1., 15\# cu ft. gilsonite and 1\% Halad 9. Cemented annulus with 25 cu ft. cement. Stood cemented 8 hours and landed $103 / 4$ " casing. Rigged down and moved off. Well suspe naled $6-13-62$

\section{$6-14-62$ \\ thru \\ $8-2-62$ \\ No activity. \\ $8-3-62$ \\ Moved in Ideco H-35, drilled out shoe and made $95 / 8$ " hole to 680 ' using atr as a drilling media. Pipe stuck at 670', pulled in top section of mast while working pipe. Moved out rig and replaced it with National T-20.}

8-4-62 Ran inside of $4 \frac{1}{2} "$ drill pipe w1th $1 \frac{1}{4}$ " tubing, unable to circulate. Ran $1 \frac{1}{4}$ " tubing on outside of drill pipe and cleaned out to $677 \%$. Worked pipe free.

8-5-62 Drilled 9 5/8" hole from 677' to 701'. Made trip and measured drill pipe. Had to drill from 592'. Hole sloughling badly at 661'. Plugged bit while drilling at 701'. Round trip to unplug bit. Drilled $95 / 8^{\prime \prime}$ hole from $701^{\prime}$ to $710^{\prime}$.

8-6-62 Pulled drill pipe up in $103 / 4 "$. Welded plate on U-3bl-2. Ran in to bottom no returns. Pulled out bit not plugged. Ran in to 480 ', circulation OK. Hole sloughed in on drill pipe with bit @ 648'. Pulled plugged bit, cleaned bit and reamed. Cleaned out sloughing gravel from 604' to

649'. Ran in to cement back. Blowing hole to clean out from 637' to 691'. Unable to make connection, at 690'.

8-7-62 With open end drill pipe hung at $690^{\prime}$ pumped in 50 sxs Hydrogel followed by $100 \mathrm{cu} \mathrm{ft}$. of Cal Seal 1-1 mix. Stood cemented 6 hours. Ran in with $95 / 8$ " bit, broke circulation at 480'. Cleaned out sloughed hole from 674' to $710^{\prime}$. Drilled 9 5/8" hole 710' to 720'. Short trip to check f111, had to clean out 34'. Made trip and ran in with $9 / 8$ " diamond polnt b1t, blowed hole clean, pulled up 50' and shut off air for 5 minutes. Found $40^{\prime}$ of fill. Cleaned out to bottom. With open end drill pipe hung at $720^{\prime}$ pumped in $100 \mathrm{cu} \mathrm{ft}$. cement.

8-8-62 Stood cemented 8 hours. Located top of fill at 627', cleaned out to $710^{\prime}$. Measured out of hole, stayed on bank one hour, re-ran drill pipe and 10cated top of fill at $689^{\prime}$, cleaned out to $710^{\prime}$. Ran in with $95 / 81$ bit and cleaned out f1ll from 618' to 628'. Pulled up 50' and shut air off for 30 minutes, found f111 to 624'. With open. end drill pipe hung (1) 620' pumped in $100 \mathrm{cu} \mathrm{ft}$. cement $1-1$ perlite $\mathrm{w} / \mathrm{th} L \% \mathrm{gel}$ and $2 \% \mathrm{CaCl}_{2}$. Located top of cement at 543'. With open end drill pipe hung at $512^{\prime}$ pumped in 100 cu ft. cement 1-1 perlite with $4 \%$ gel and $2 \% \mathrm{CaCl}_{2}$. 
WeIl History

Stn. U-3bl-3

page: 2

8-9-62 Stood cemented 4 hours. With open end drill pipe hung at 488' pumped in $100 \mathrm{cu} f$. cement $1-1$ perlite with $4 \%$ gel and $2 \% \mathrm{CaCl}_{2}$. Stood cemented 4 hours. Tagged top of cement at 519'. With open end drill pipe hung (2) $488^{\prime}$ pumped in $100 \mathrm{cu}$ ft. cement $1-1$ perlite with $4 \%$ gel and $2 \% \mathrm{CaCl}_{2}$. Rigged down and moved out.

8-10-62 Hole idle.

8-11-62 Moved in portadrill rig and pushed HOWCO plug to 450'. Placed 2 xsxs Cal-Seal on top of plug. Felt for plug in one hour, plug not in place. Set HOWCO plug with drill pipe at $458 \%$. Pumped in 10 sxs Cal-Seal, followed by $237 \mathrm{cu} \mathrm{ft}$. cement with $2 \% \mathrm{CaCl}_{2}$. $103 / 4$ " plugged to surface. Rigged down and moved out. Hole abandoned $8-11-62$. 
HOLMES \& NARVER, INC.

WELL HISTORY DATA

HOLE NUMBER U-3bI PS-1

WORK ORDER NUMBER__ 1216-40

H\& N I.D. NUMBER 182753

E.D.S. NUMBER

LASL

USER

LOCATION:_Nevada (N.T.S.)

Coordinates N836,405.73
TYPE HOLE Post Shot

County Nye Aroa

$5687,585.29$
3991.3

RIG SCHEDULE: MOVED ON LOCATION_8-24-62_ SPUDDED_8-24-62_ 8-25-62

REMARKS: USER ACCEPTANCE $8-25-62$

MUD PROGRAM:

Gel. \& Water

DRILLING EQUIPMENT.

National $\mathrm{T}-20$

\begin{tabular}{|c|c|c|c|c|c|c|c|c|c|}
\hline \multicolumn{3}{|c|}{ BORE HOLE RECORD } & \multicolumn{7}{|c|}{ CASING RECORD } \\
\hline FROM & TO & SIZE & SIZE & WEIGHT & GRADE & COUPLING & FROM & TO & $\begin{array}{l}\text { SACKS } \\
\text { CEMENT }\end{array}$ \\
\hline $0^{1}$ & $38^{\prime}$ & $17 \frac{1}{2} " 1$ & $103 / 4 "$ & Surfaco & & & $0 !$ & 381 & $56 \mathrm{cu} \mathrm{ft}^{\mathrm{s}}$ \\
\hline 381 & 7681 & $9598 n$ & & & & & & & \\
\hline & & & & & & & & & \\
\hline & & & & & & & & & \\
\hline & & & & & & & & & \\
\hline
\end{tabular}

TOTAL DEPTH_ $768^{\prime}$

WORKING POINT

PLUGS

None

JUNK None

LOGGING DATA Lane Wells Gamma ray and temperature logs to $768^{\prime}$.

Sperry Sun Magnetic survey to $766^{\prime}$.

DEVIATION DATA: M.D. BOTTOM HOLE COORDINATES $0765^{\prime}$ N836, $413.53, \mathrm{E} 687,595.14$ CORING HISTORY None taken. 
Well History

Stn. U-3bl PS-1

$8-24-62$

Moved in Portadrill on crater floor. Drilled $17 \frac{1}{2} "$ hole to 381. Set and cemented $103 / 4^{\prime \prime}$ casing at 38 ' with $56 \mathrm{cu} f \mathrm{ft}$. of Cal-Seal. Moved out portadrill rig. Moved in National T-20 rig, drilled out $103 / 4 "$ shoe and made $95 / 8 "$ hole to 164 '.

Drilled $95 / 8$ ' hole from $164^{\prime}$ to 768 '. Lost circulation while drilling at $490^{\prime}$. Ran Lane Wells gamma ray \& temperature logs to 7681 . Took Homco side wall samples. Ran Sperry Sun Magnetic survey to 766'. Rigged down and moved out. Hole completed 8-25-62. 


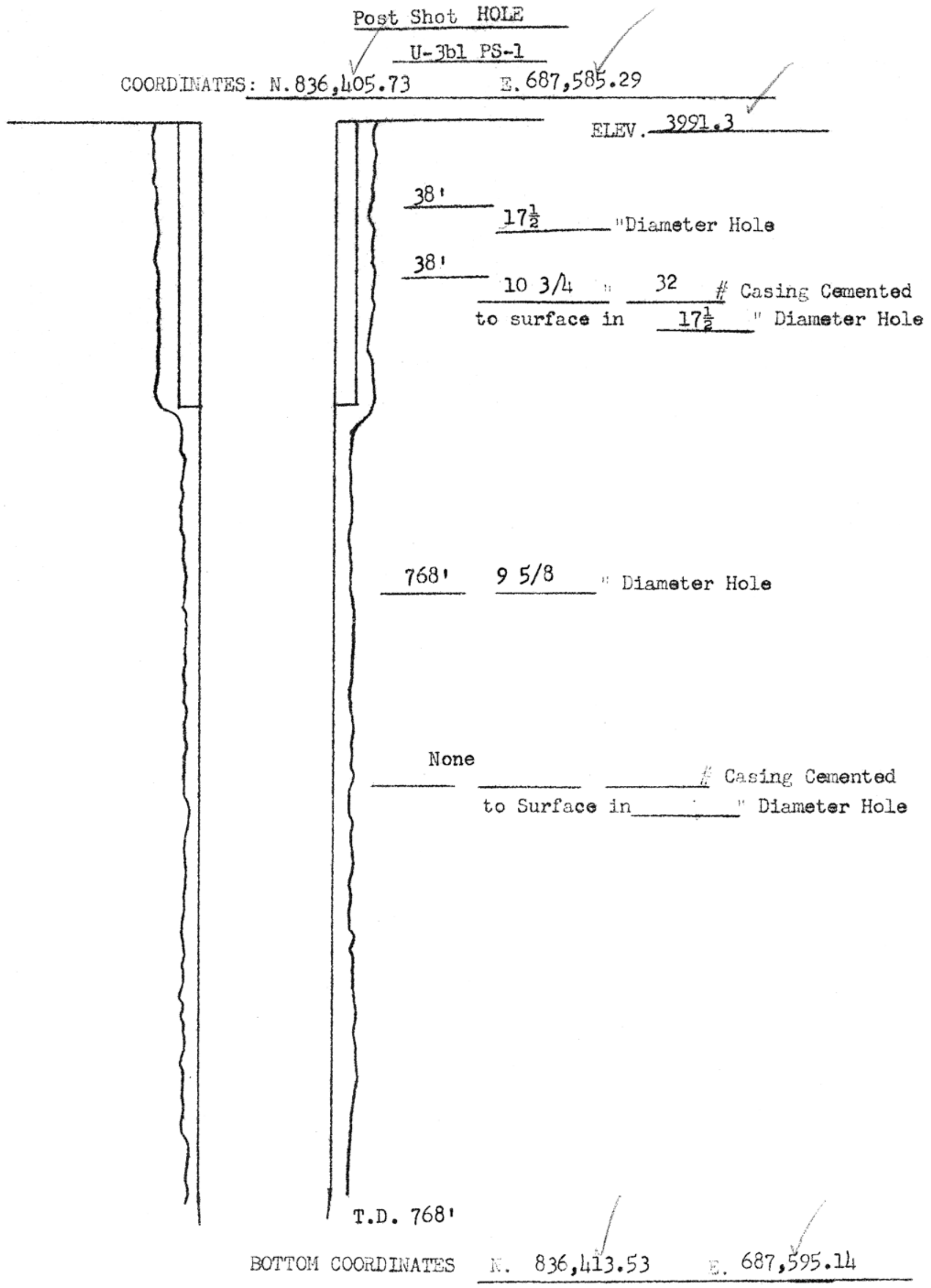


HOLMES \& NARVER, INC.

WELL HISTORY DATA

\begin{abstract}
HOLE NUMBER U-3bI PS-2
\end{abstract}
WORK ORDER NUMBER_1216-40 H\& N I.D. NUMBER 182753

E.D.S. NUMBER

USER -

LASL

LOCATION: Nevada (N.T.S.) TYPE HOLE

Post Shot

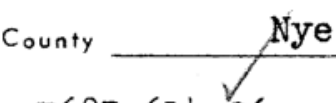

Area<smiles>[Te]</smiles>

Coordinates $\mathrm{N} 836,406.05$

$.5687,614.96$

Surface Elevation 3991.3

RIG SCHEDULE: MOVED ON LOCATION $8-24-62$

SPUDDED

$8-24-62$

COMPLETED $\quad 8-26-62$

REMARKS:

USER ACCEPTANCE

$8-26-62$

MUD PROGRAM:

Gel. \& Water

DRILLING EQUIPMENT. IdeCO H- 35

\begin{tabular}{|c|c|c|c|c|c|c|c|c|c|}
\hline \multicolumn{3}{|c|}{ BORE HOLE RECORD } & \multicolumn{7}{|c|}{ CASING RECORD } \\
\hline FROM & TO & SIZE & SIZE & WEIGHT & GRADE & COUPLING & FROM & TO & $\begin{array}{l}\text { SACKS } \\
\text { CEMENT }\end{array}$ \\
\hline 01 & 381 & $15 "$ & $103 / 4 "$ & Surface & & & $0^{1}$ & 381 & $59 \mathrm{cu} f t$. \\
\hline 381 & 7651 & $95 / 81$ & & & & & & & \\
\hline & & & & & & & & & \\
\hline & & & & & & & & & \\
\hline
\end{tabular}

TOTAL DEPTH

$765^{\prime}$

WORKING POINT

PLUGS

JUNK

None

LOGGING DATA

Sperry Sun Multishot to $770^{\prime}$.

Lane Wells Temperature and gamma ray to $773^{\prime}$.

DEVIATION DATA: M.D. $770^{\prime}$

v.o. $769.94^{\prime}$

REFERENCE SUR - 435

BOTTOM HOLE COORDINATES__0770' N836,406.74 E687,618.50 
Well History

Stn. U-3bl PS-2

8-24-62 Moved Portadrill into floor of crater. Drilled 15' hole to 38'. Set and cemented $103 / 4^{\prime \prime}$ casine, at 381 with $59 \mathrm{cu} \mathrm{ft}$. cement. Moved out portadrill and moved in Ideco $\mathrm{H}-35$.

8-25-62 Drilled out shoe \& made $95 / 8$ " hole to $765^{\prime}$. Lost circulation (a) 499'. Ran Lane Wells Temperature and Gamma ray logs to $773^{\prime}$. Took Homco sidewall samples.

8-26-62 Ran Sperry Sun multishot to 770'. Laid down drill pipe. Rigged down and moved out. Well completed 8-26-62. 


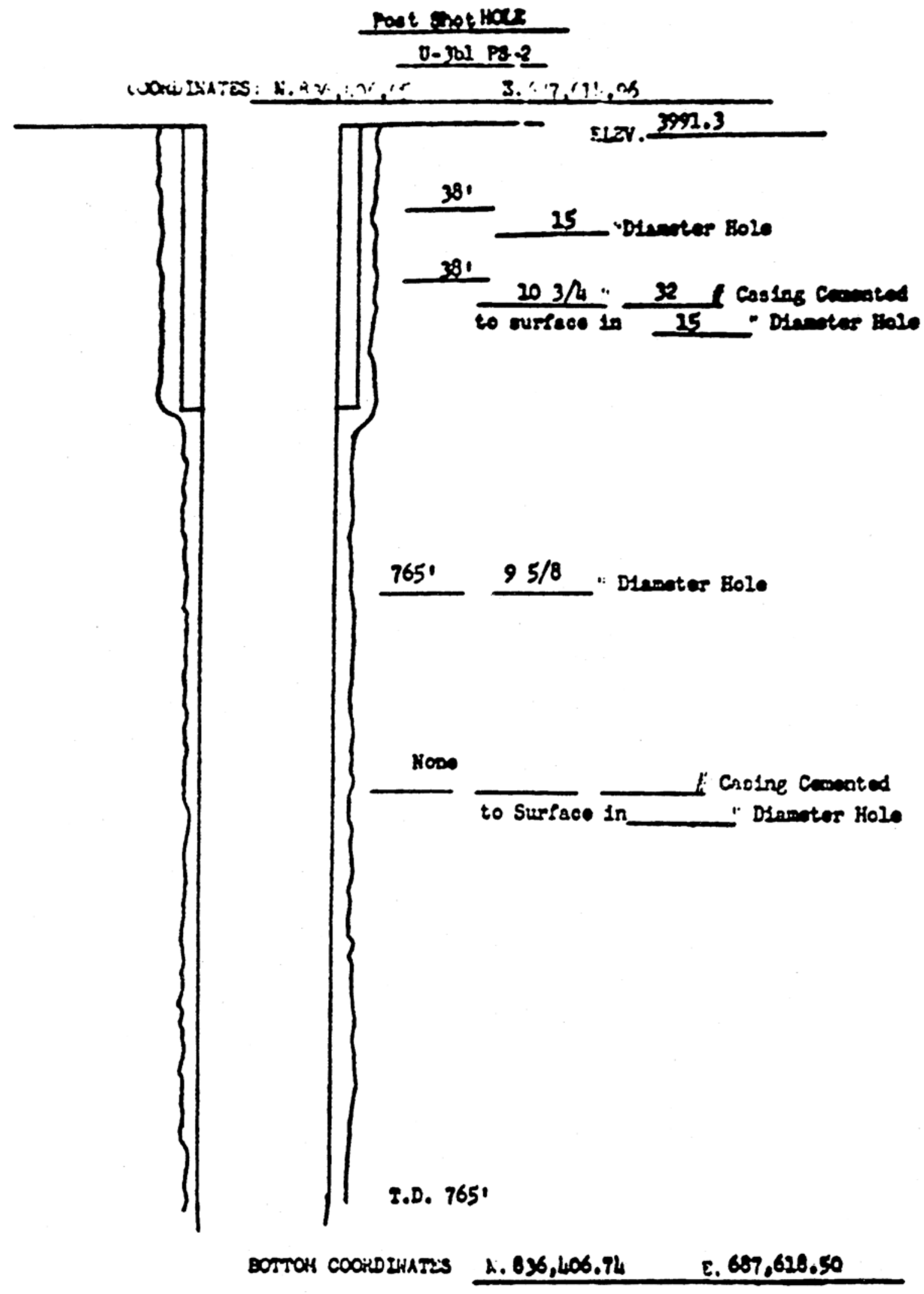




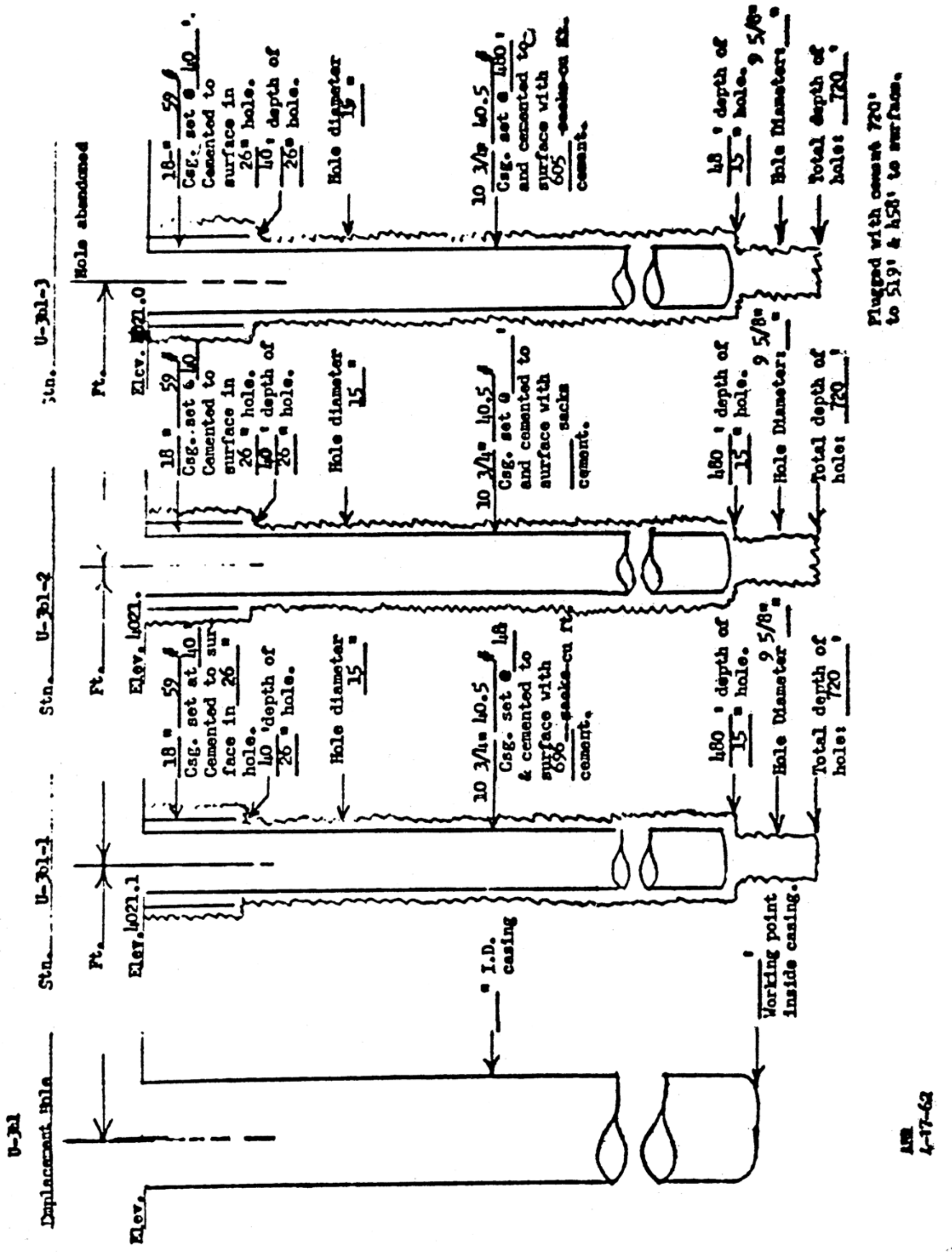




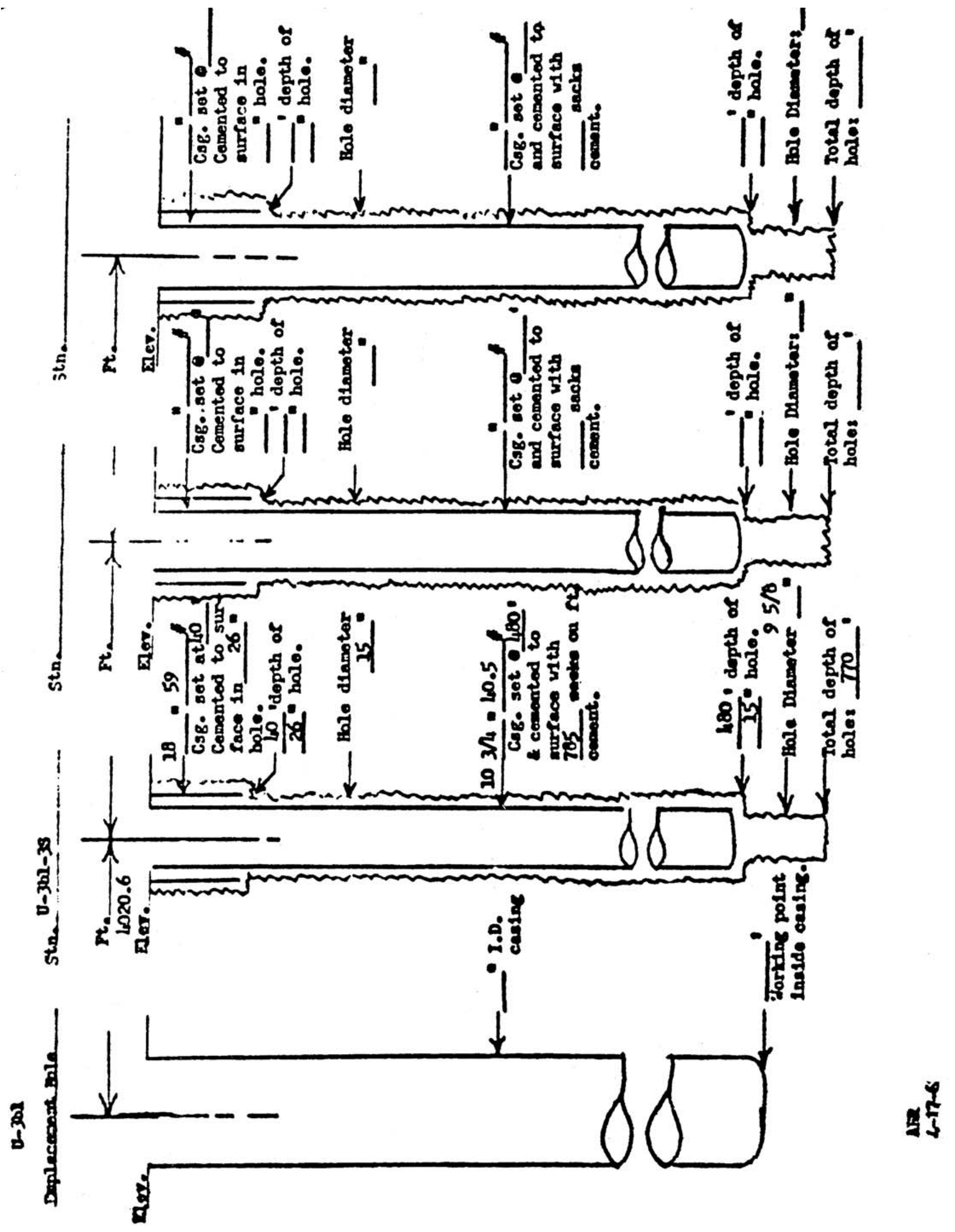




\section{Appendix F}

U3lb site characterization

Note: From containment prospectus. 


\section{Site Characterization}

An existing inventory hole, U3lb, has been selected for NAVATA. A DOB of $183 \mathrm{~m}$ has been chosen, uting the minimum DOB convention. This emplecement hole is situated in north-central Area 3 and is in inaturated tuffaceous alluvium. The hole construction history does not indicate eny geologic pacularities encountered during druling.

Surface features of interest in the area re shot-related radial and concentric fractures and the Area 3 fault (Flgure 5). Some minor fracturing has occurred elong the fault as a result of the BILBY (U3en) and SCAUP (U3das) events conducted in 1963 and 1965, respectively. Within one DOB of U3lb there were two minor discontinuous eracks mapped which are no longer visible. The U3eo (FAWN) collapse sink and associated concentric eracks to the northwest extend to within E-Troximately $110 \mathrm{~m}$ of the NAVATA SGZ. The elosest epproach from the NAVATA WP to the FAWN chimney is estimated to be $155 \mathrm{~m}$ (14.6 $R_{c}$ ). CANFIELD (U3kx), $300 \mathrm{~m}$ NNE, collepsed to the ourface and produced only minor aurface effects and no cracking along the Area 3 fault.

Since U3lb did not penetrate the tuff: (Appendix Table A-2, Lithologic oummary), the stratigraphy below the alluwium is projected from narby hales, primrilly U3kx (Appendix Table A-3) which is in a very dimiler otructural catting. Besed on the USGS gravity interpretation, the Paleozole surface is eatimated to be come $850 \mathrm{~m}$ below the WP. The nearest trill hole which penetrated the Pz ouface is U3en-5, located epproximately $725 \mathrm{~m}$ north of U3lb. The P2 was tagged at $860 \mathrm{~m}$. The dlluvium/tuff contact in U3Ib is predicted to be at a depth of $275 \mathrm{~m}, 91 \mathrm{~m}$ below the WP. The atatic water level (SWL) depth is predieted at approximately $491 \mathrm{~m}$. 


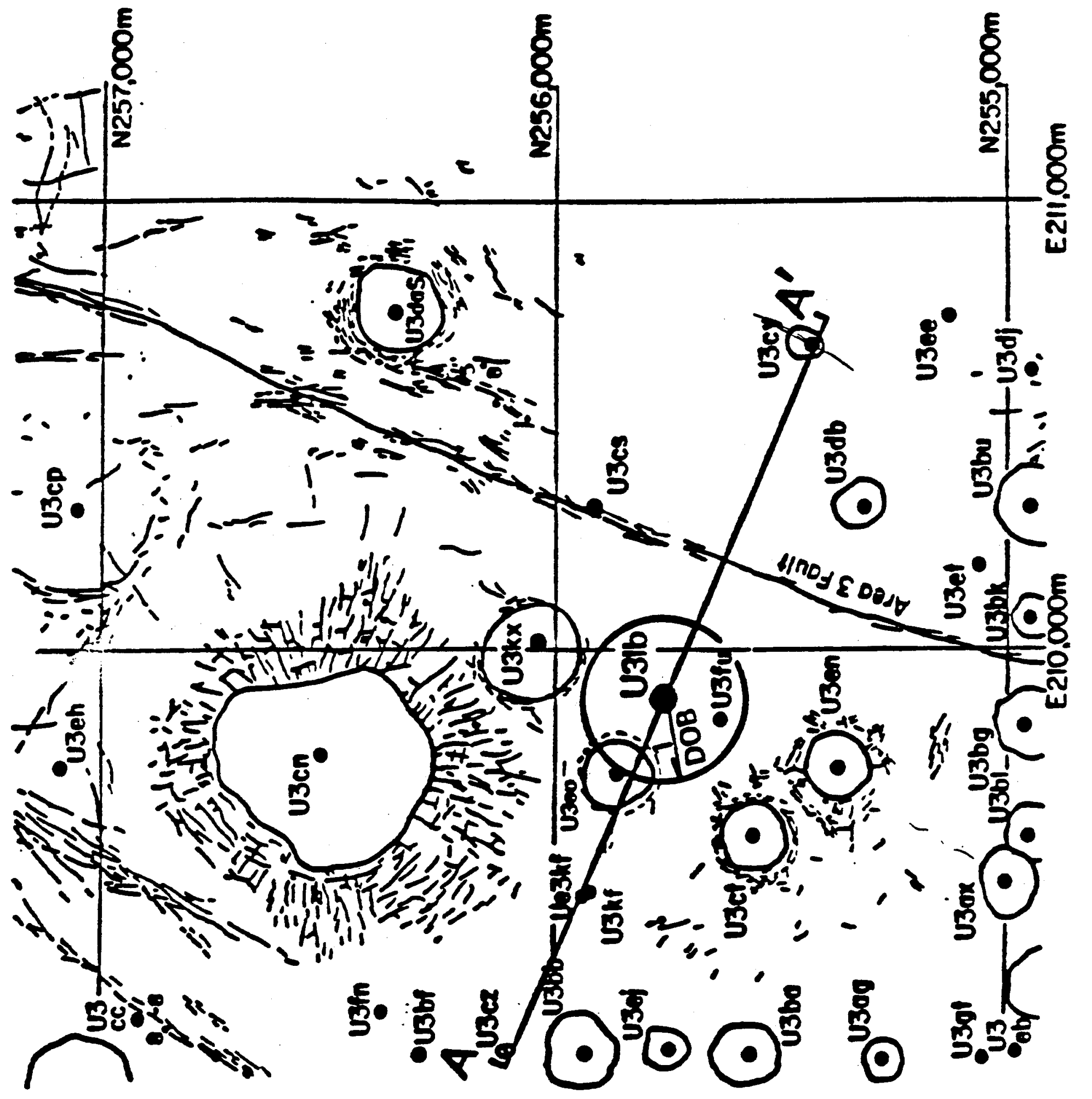

Figure 5 


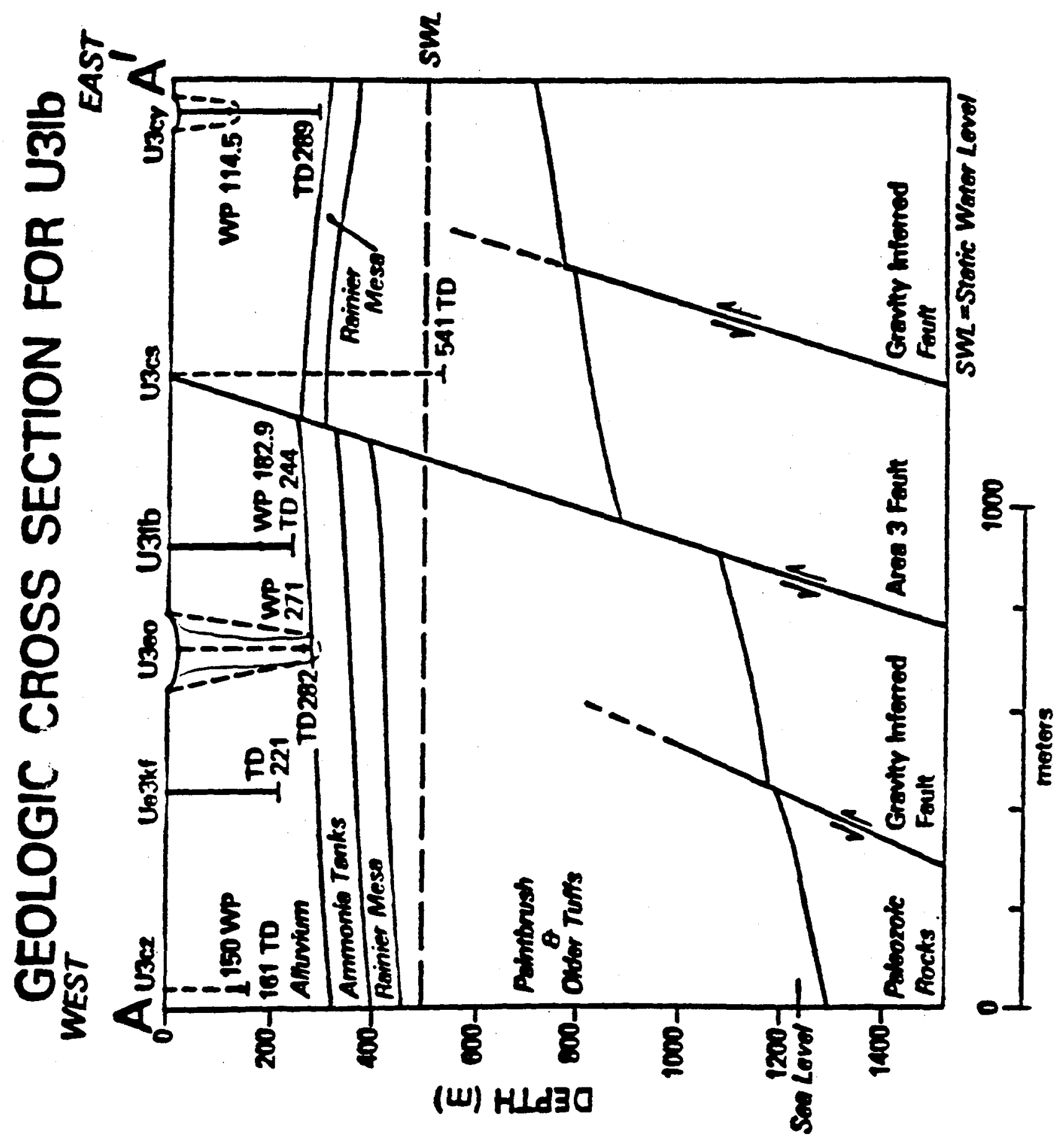


In order to best depiet the structural setting the geologic cross section (Figure 6) was constructed normal to the atructural trend of approximately $N 23^{\circ} \mathrm{E}$. The major structural feature in the vicinity is the Area 3 fault to the cest. At closest approach the fault plane is mare than $240 \mathrm{~m}$ from the athot-polnt. The USCS gravity interpretation (Appendix Figure A-d) showe a feult to the west in the pre-Cenozoic rocks, but there is no surficial evidence of this fault. BLBY did not produce any surface craeks in this Jocation.

Plots of the caliper, resistivity, density, and geophone veloelty logs are shown in Figure 7. The caliper log, run on 4 July 1982, show a very amooth tole for alluvium with the maximum enlargement at $230 \mathrm{~m}$ to $1.51 \mathrm{~m}$. This is $16 \%$ greater than the bit size of $1.32 \mathrm{~m}$. Indieated areas of enlargement are all outside the max-cred cevity region.

No zones of low resistivity were noted on the electric log. Reeistivities are generally between 200 and 300 ohmmeter with a minimum of approximately 200 ohmmeters at $124 \mathrm{~m}$ depth.

The density $\log$ indicates an everage of $1.64 \mathrm{Mg} / \mathrm{m}^{3}$ for the overburden and $2.74 \mathrm{Mg} / \mathrm{m}^{3}$ for the max-ered cavity region. These values are well within previous experience for Area 3 elluvium.

The geophone log indicates average velocitios of $1235 \mathrm{~m} / \mathrm{kec}$ for the overburden and $1524 \mathrm{~m} / \mathrm{sec}$ for the max-ered cavity region, which compere very well with those in U3kx at the same depths and with other holes with simllar working point environments. 


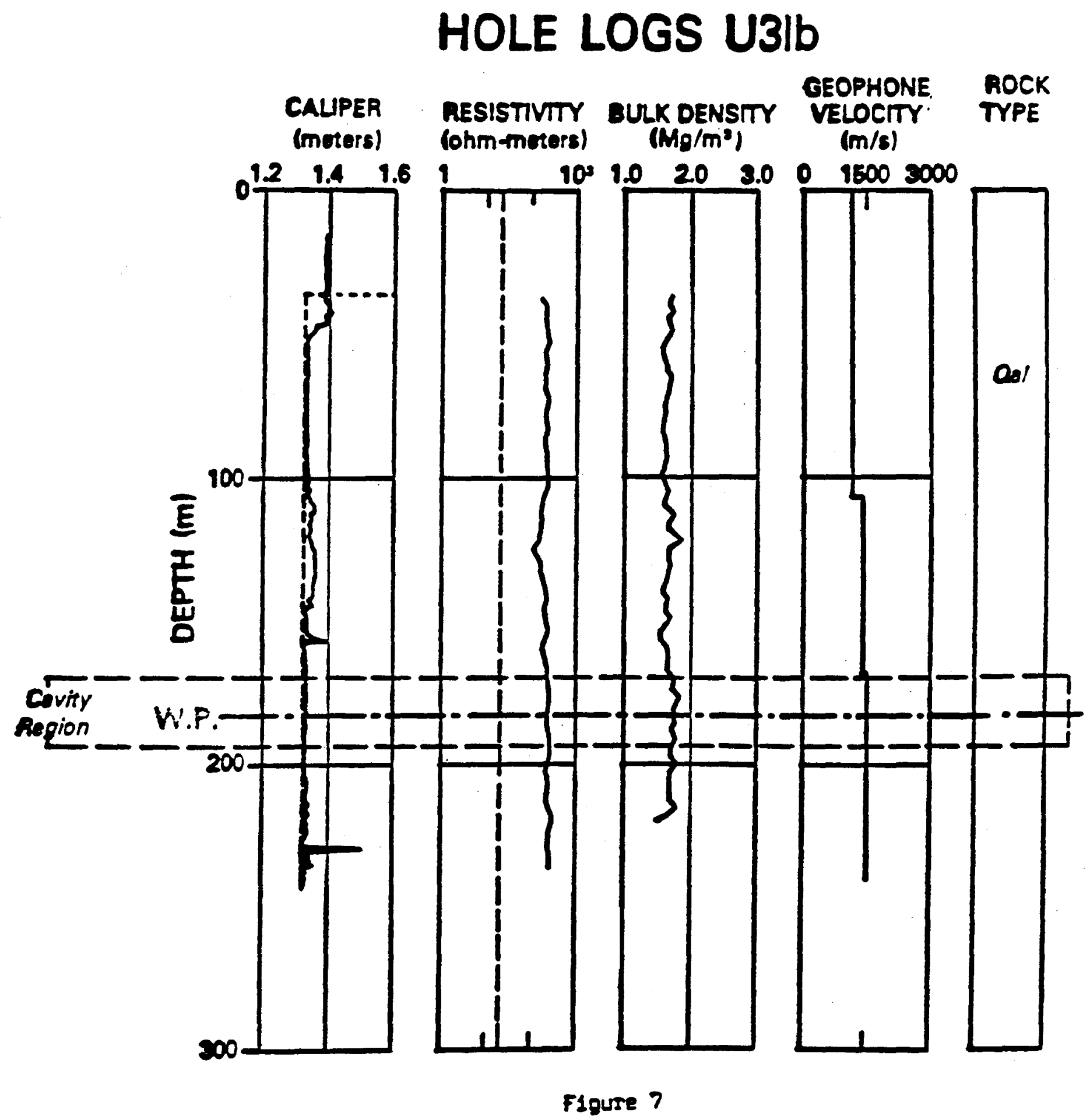


Since, for reasons mentioned below, there are only two sidewall samples from the cavity region, water contents were derived from the hytrogen index log (computed from the epithermal neutron and density logs - Figure B). The averages are 12.2 wt \% in the max-ered cavity region and $22.5 \% \%$ in the overburden. This agrees well with values determined from sidewall samples taken in the eame intervals.

The material properties for the medium above and within the cavity region are normal for unsaturated alluvium. Since this tole was drilled for a planned usedepth of $229 \mathrm{~m}$, the original sampling plan included points on $15 \mathrm{~m}$ intervals - -oughout the zone of interest. With the asignment of NAVATA at a lesser depth, :ision gun samples were obtained to provide edequate data for cneracterization. Table tIl provides average cavity region and overburden values; Table IV provides all of the sample data. Grain densities average $2.51 \mathrm{Mg} / \mathrm{m}^{3}$ and the $\mathrm{CO}_{2}$ content is $1.4 \%$ within the cavity region. A data source summary is given in Appendix Table A-4. Histograms of Area 3 experience in unseturated alluvium are presented in Figures 9, 10, and 11 with discrete values given in Appendix Table A-5.

No unusual or hazardous geologic characteristics were revealed; we conclude U3lb Is a eatisfectory location in which to execute NAVATA with complete containment. 


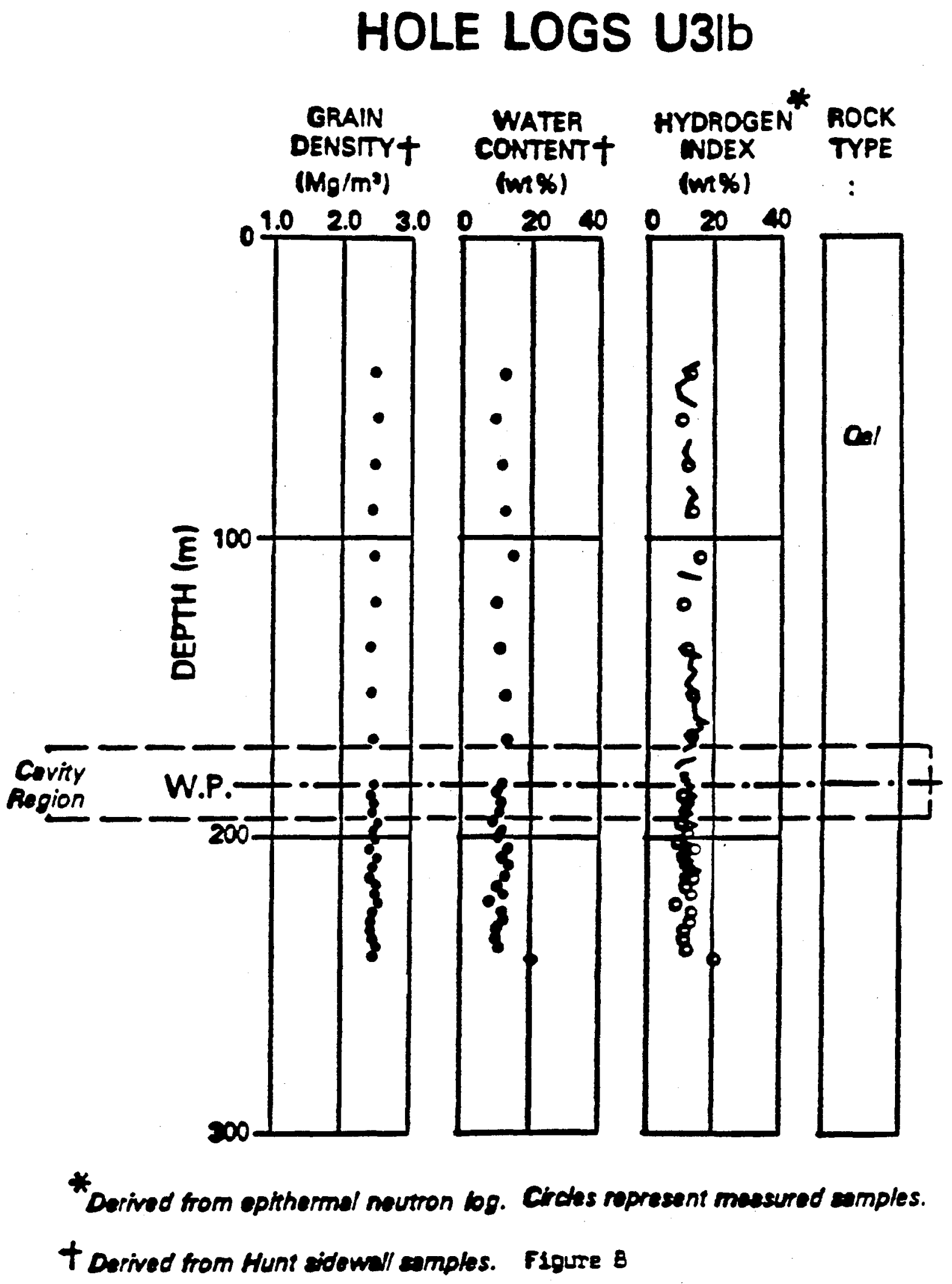




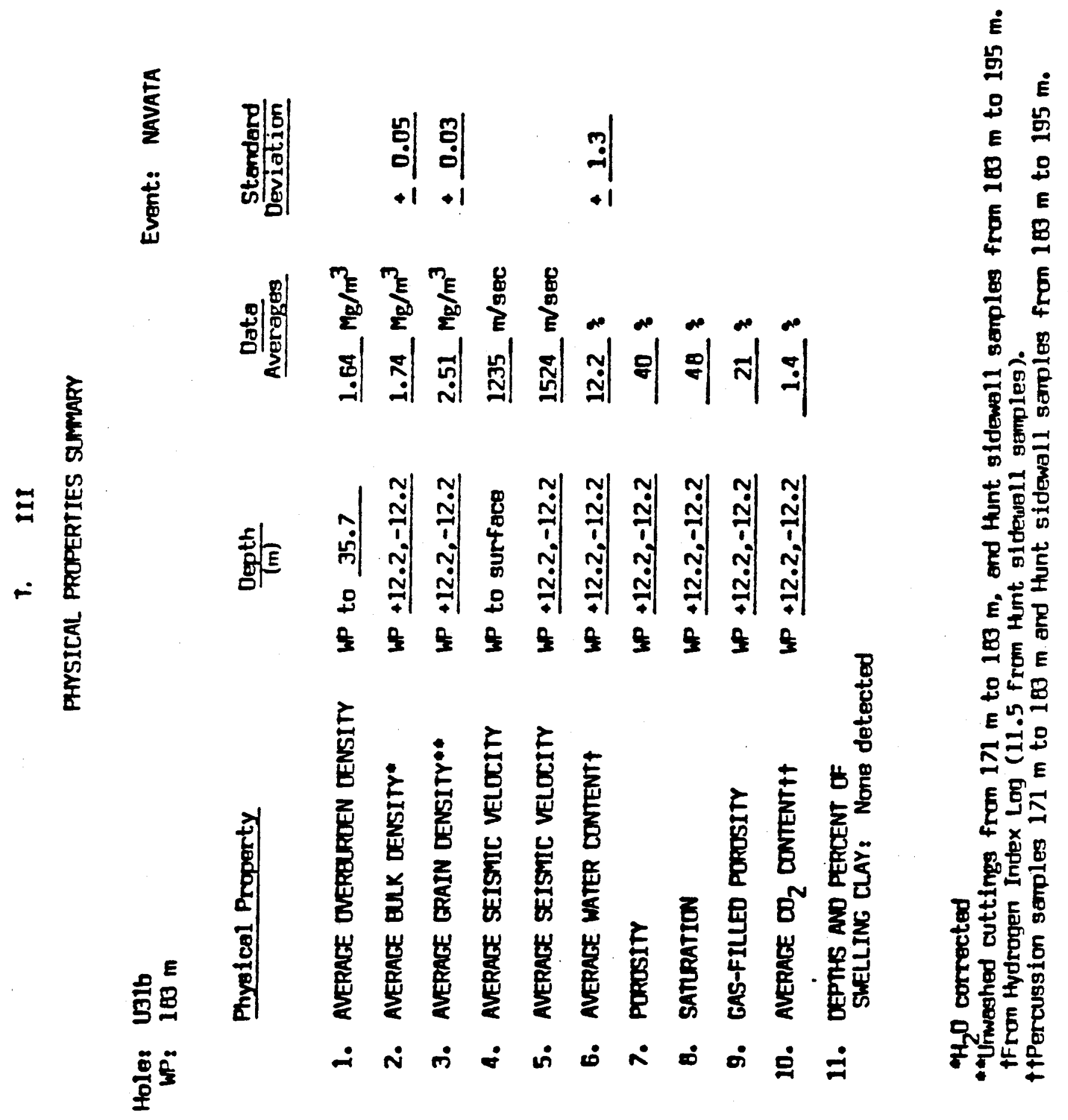




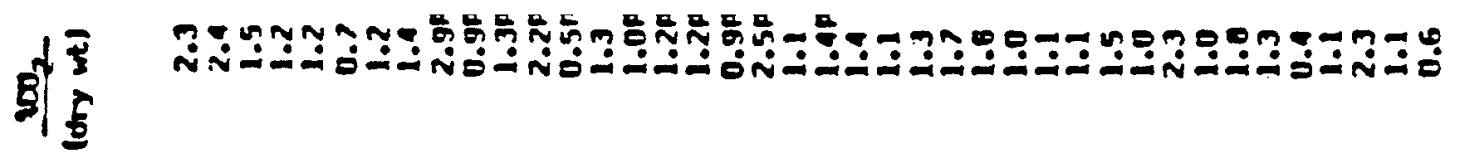

高

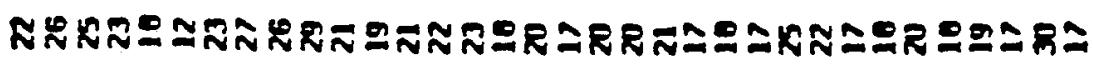

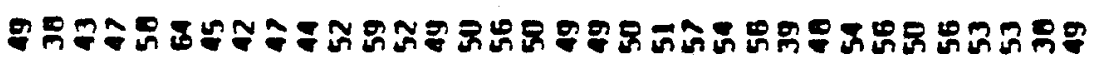

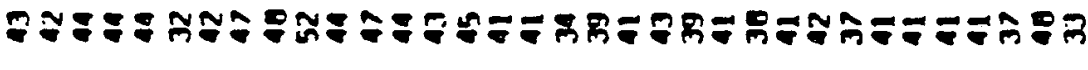

$\frac{1}{8}$

焉

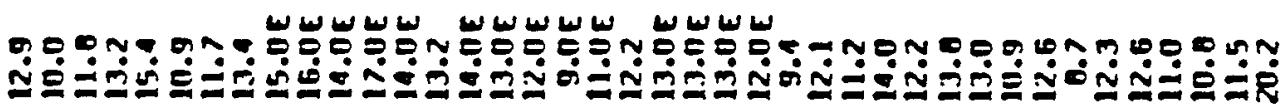

产高

B.

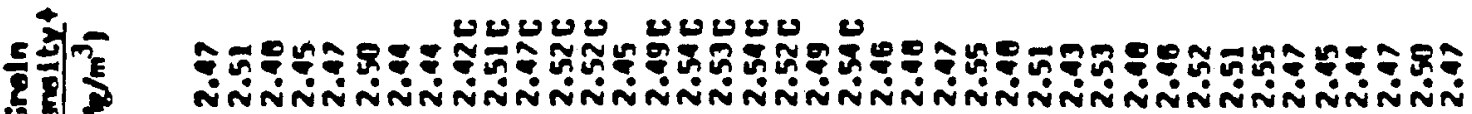

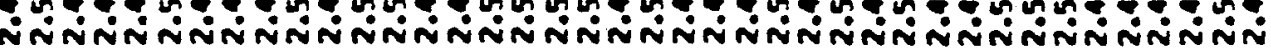

昔

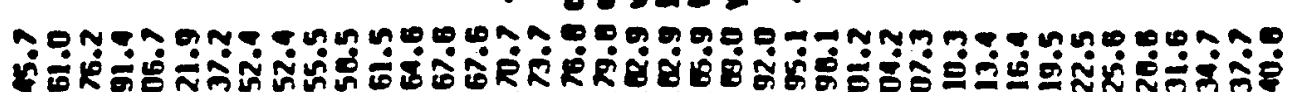



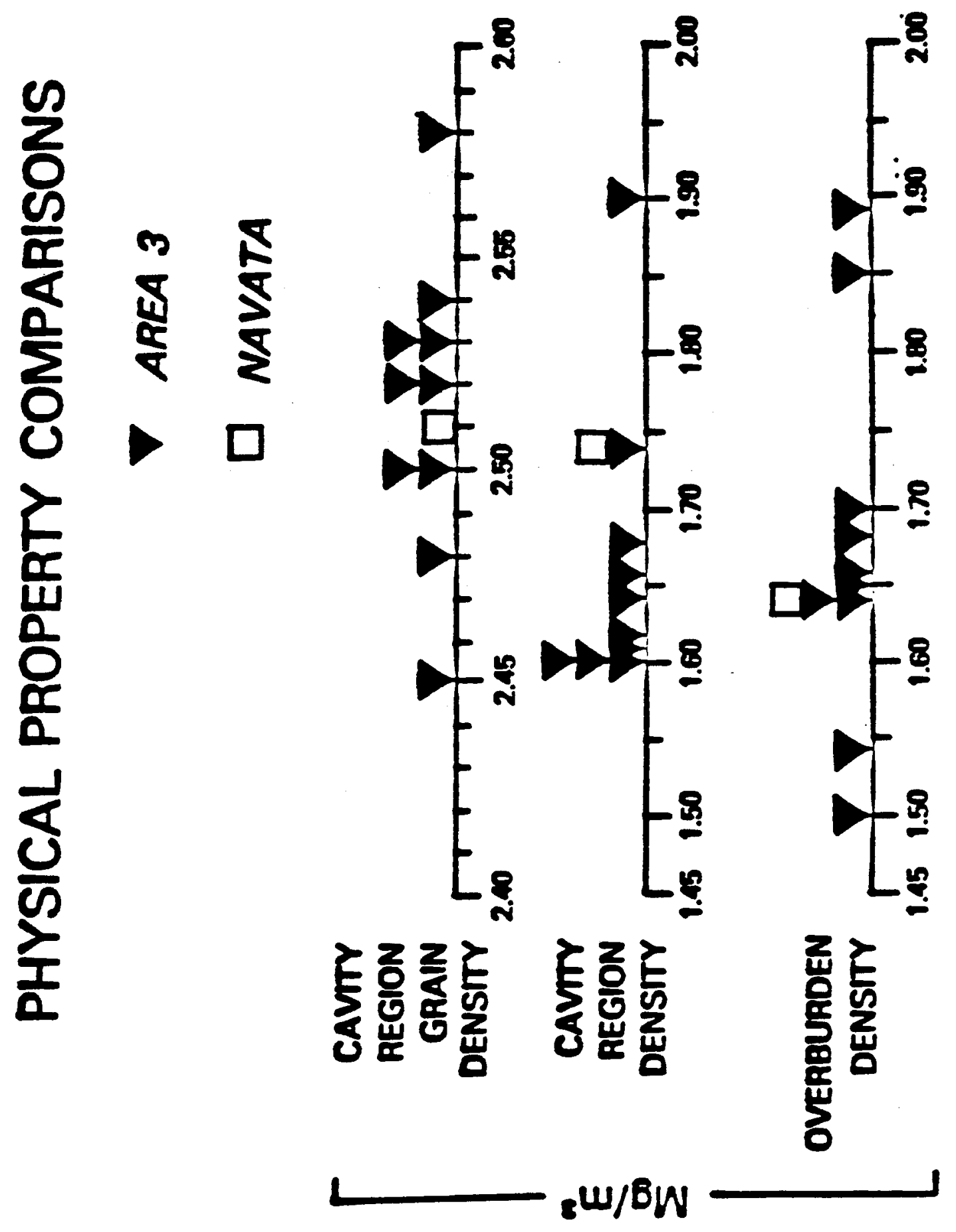

Figure 9 


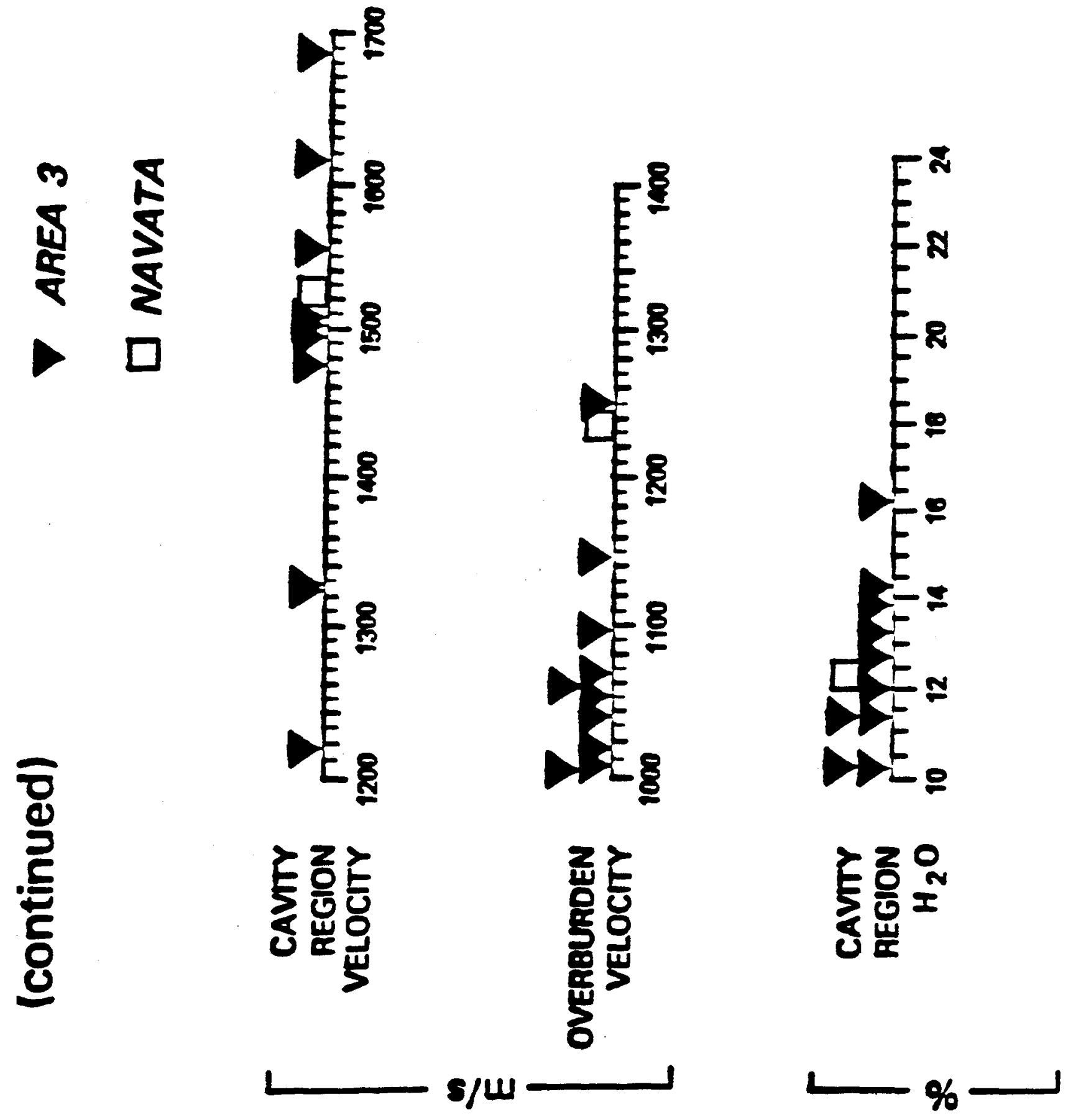

Fsqure 10 


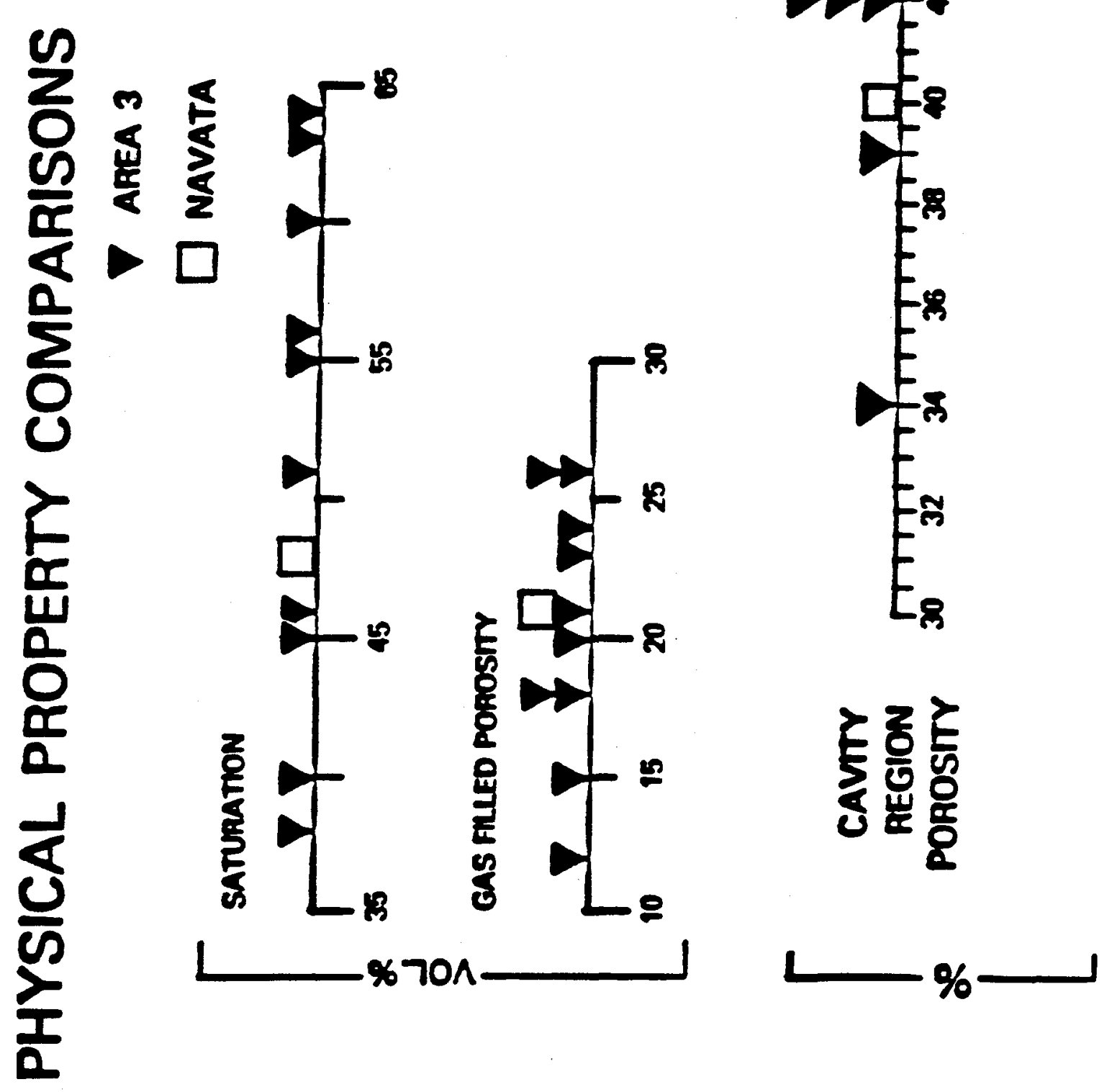

Floure 11 
TABLE A-2

Lithologic Summary for U3lb Emplacement Hole from cuttings, sidewall amples and geophysical logs

Logged by S. L. Drellack, Jr.

Fenix and Seizon, Ine.

Depth

(Meters)

$0 \cdot 243.8 \mathrm{~m}$
Lithologic Deseription

Stratigraphic

Unit

\begin{abstract}
Alluvium: Generally moderate-yellowish brown, some dark-yellowist-brown; tuffaceous; subangular to subrounded; poorly to moderately sorted; predominately silt to coarse sand aizes, scarce granules and inall pebbles; nonindurated; scarce (K2\%) Paleozoic rock fragments; slightly calcarous.
\end{abstract}

Alluvium 
Lithologie Log for U3kx

Logged by Rite Romers and Suren Dougles

Fenix and Scieson, Inc.

Depth

(Meters)

$0.0-274.3$

$274.3-323.0$

$323.0-374.9$

$374.9-387.0$

$387.0-403.4$

$408.4-438.9$

\section{Lithologic Description}

Alluvium, fine to coarse gralned sand and pebbles; medium brown, poorly indurated, tuffaceous fragments, alightly ealcareous.

Tuff, ash-flow, non-to partially welded; pinkish gray, vitric pumice; erystal rich, quartz, chatoyant sanidine, minor sphene, biotite, sparse red biotlte, sparse red lithic fragments.

Tuff, esh-flow, nonwelded; light brown, vitric; feldspar, quartz, rere chatoyant sandine, vitric pumice, blotite. Crystal content increases with depth. Interval between 348.0 - $353.6 \mathrm{~m}$; Tuff, ash-flow, partially welded pink, quartz and feldspar erystals, abundant biotite, lithic fragments.

Tuff, ash-flow, moderately to densely welded; pink to black, vitric, eryatals of quartz, feldspar and biotite.

Tuff, ash-flow, partially welded pink, fine grained matrix, vapor phase eryotals in pumice; crystal poor, quartz, feldsper, biotite.

Tuff, esh-fall, including reworked and bedded zones and tuff seceous sandstone; zeolitized, light yellowish brown, fine grained matrix, phenocryots include quertz, feldspar, biotite, rod and black lithic fragments.
Stratioraphic Unit

Alluvium

Ammonie Tanks Member, Timber Mountein Tuff

Ammonia Tanks Member, Timber Mountain Tuff

Rainier Mesa Member, Timber Mountain Tuff

Rainier Mess Member, Timber Mountein Tuff

Palnibrush 


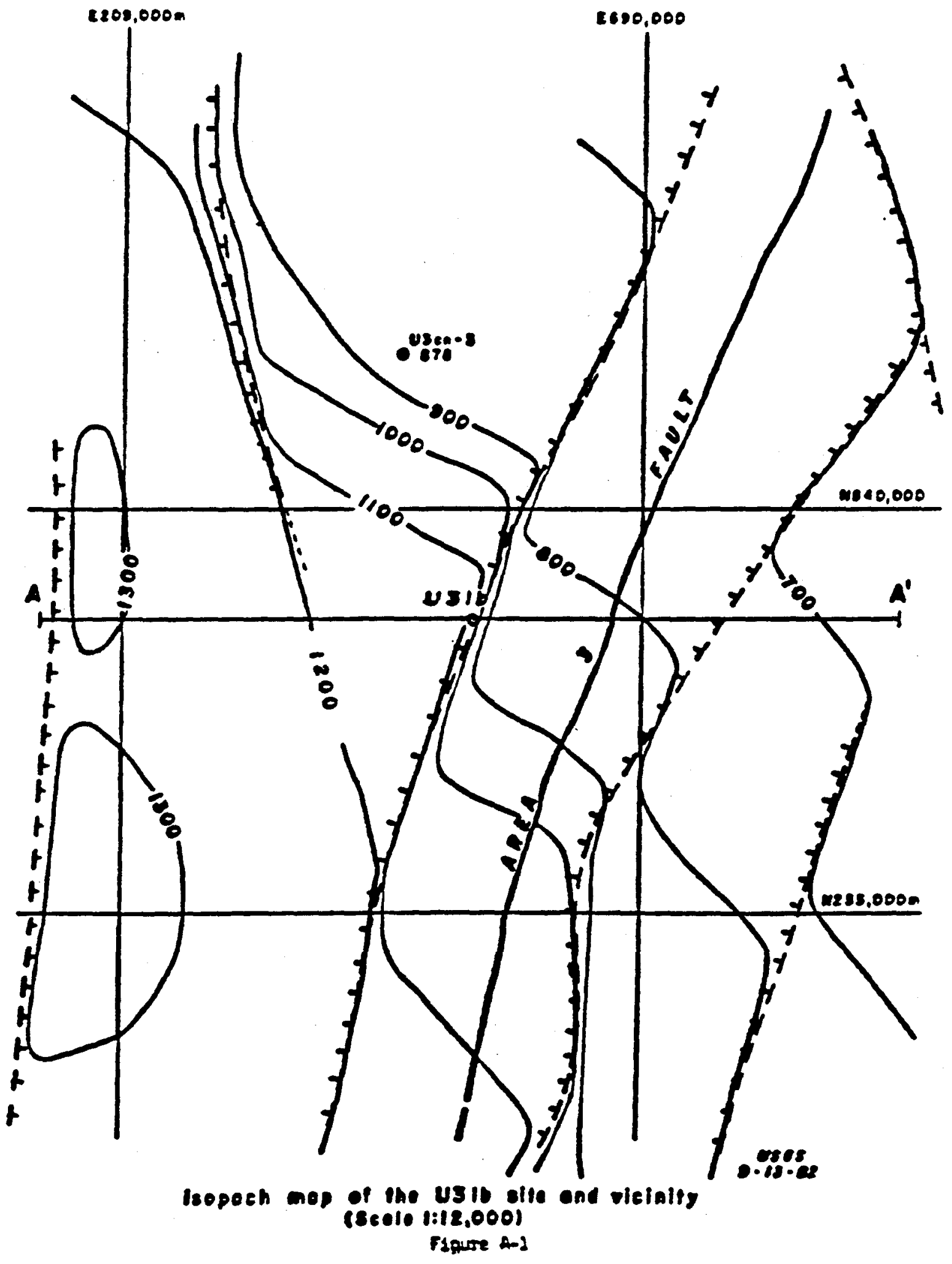




\section{ATTACHMENT B}

BOREHOLE LOG SHEETS FOR U-3bI-D2 


\section{APPENDIX B \\ BOREHOLE LOG SHEETS FOR HOLE U-3bl-D2}

\section{LEGEND}

$\begin{array}{ll}\text { ARCH } & \text { Archive Sample } \\ \text { BN } & \text { Bechtel Nevada } \\ \text { C } & \text { Common: although not dominant, is prevalent throughout sample } \\ \text { COLOR } & \begin{array}{l}\text { Refer to Munsell Soil Color Chart that defines hue, value (brilliance), and chroma } \\ \text { (purity). }\end{array} \\ \text { D } & \text { Dominant: primary constituent in the sample } \\ \text { DRI } & \text { Desert Research Institute sample } \\ \text { HF } & \text { Huffman Laboratories, Inc. sample } \\ \text { LL } & \text { Lawrence Livermore National Laboratory sample } \\ \text { NW } & \text { Northwest Laboratory sample } \\ \text { P } & \text { Present: occurs regularly throughout the sample } \\ \text { R } & \text { Rare: occurs infrequently in the sample } \\ \text { USCS } & \text { Unified Soils Classification System - refer to American Society of Testing and } \\ & \text { Materials (1984) for a listing of appropriate group symbols. }\end{array}$




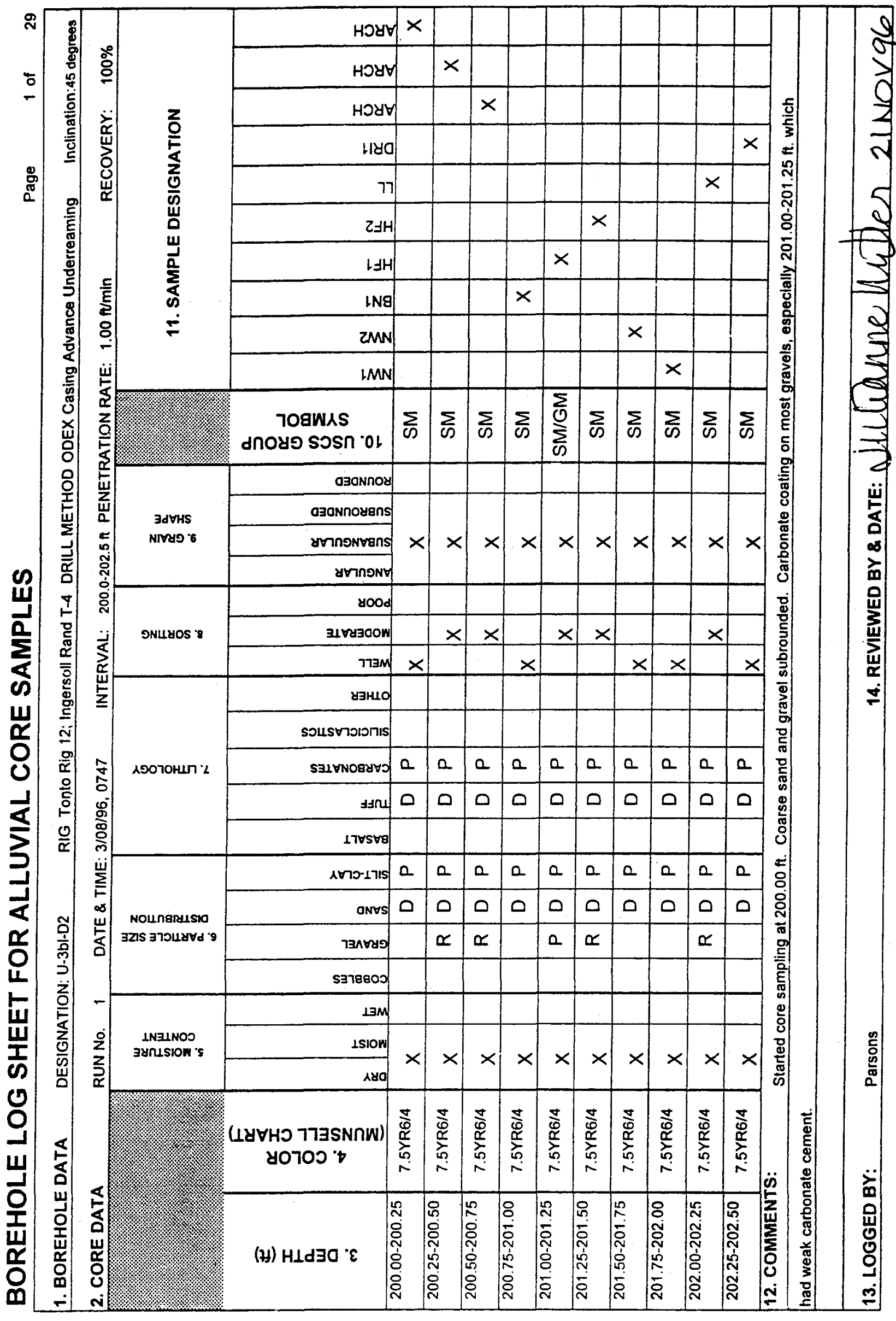




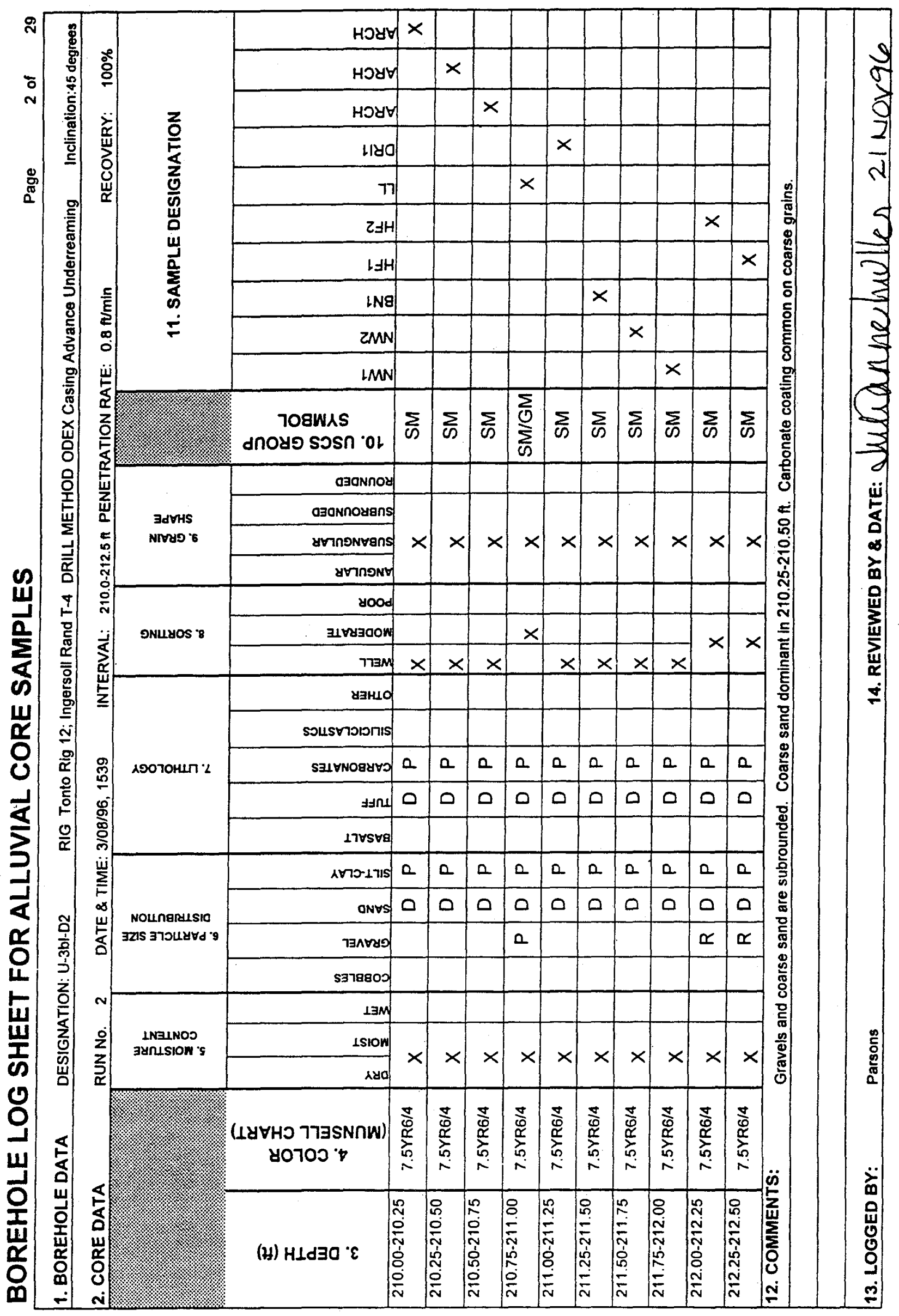


Hydrogeologic Characterization of U-3bl Collapse Zone

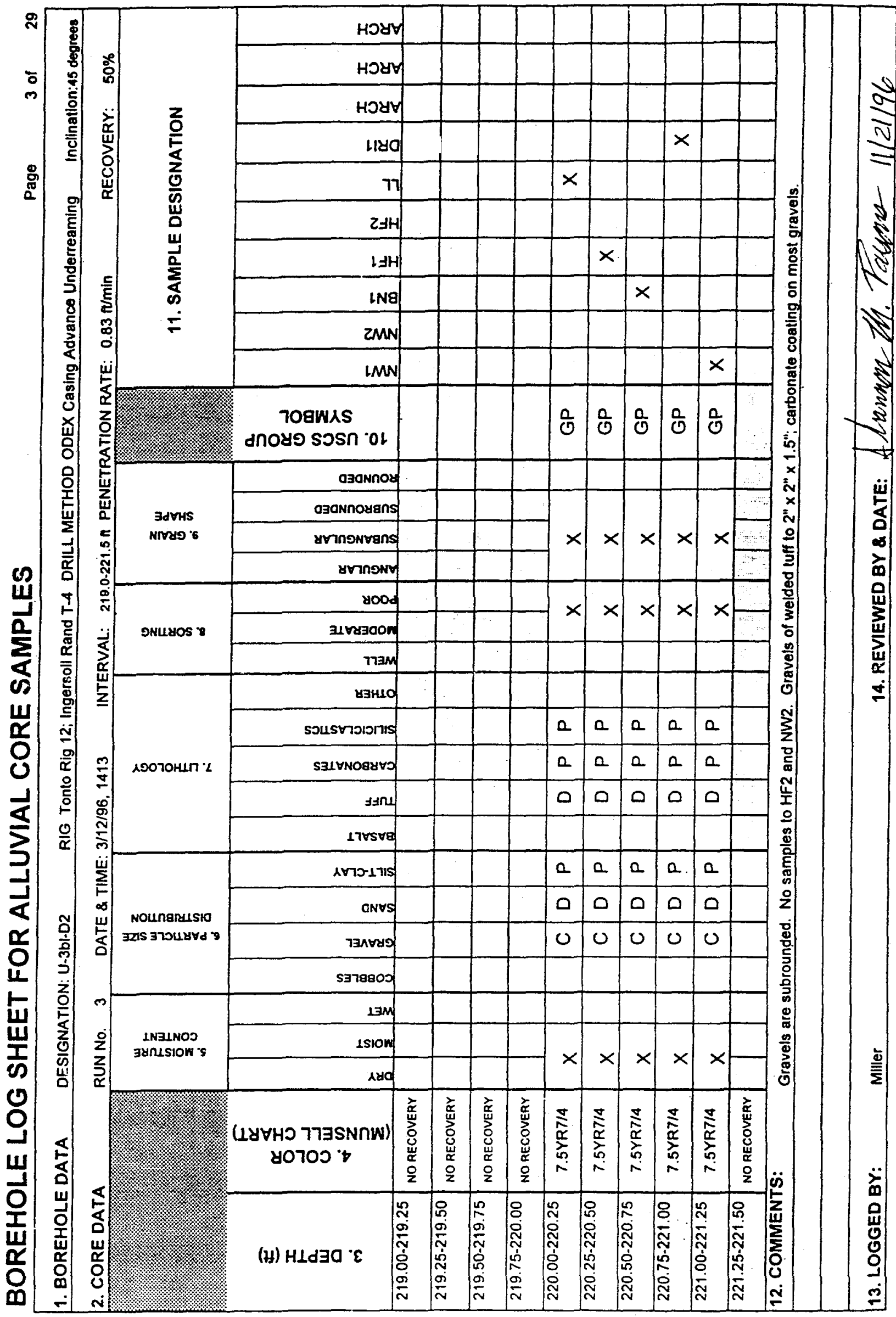


Hydrogeologic Characterization of U-3bl Collapse Zone

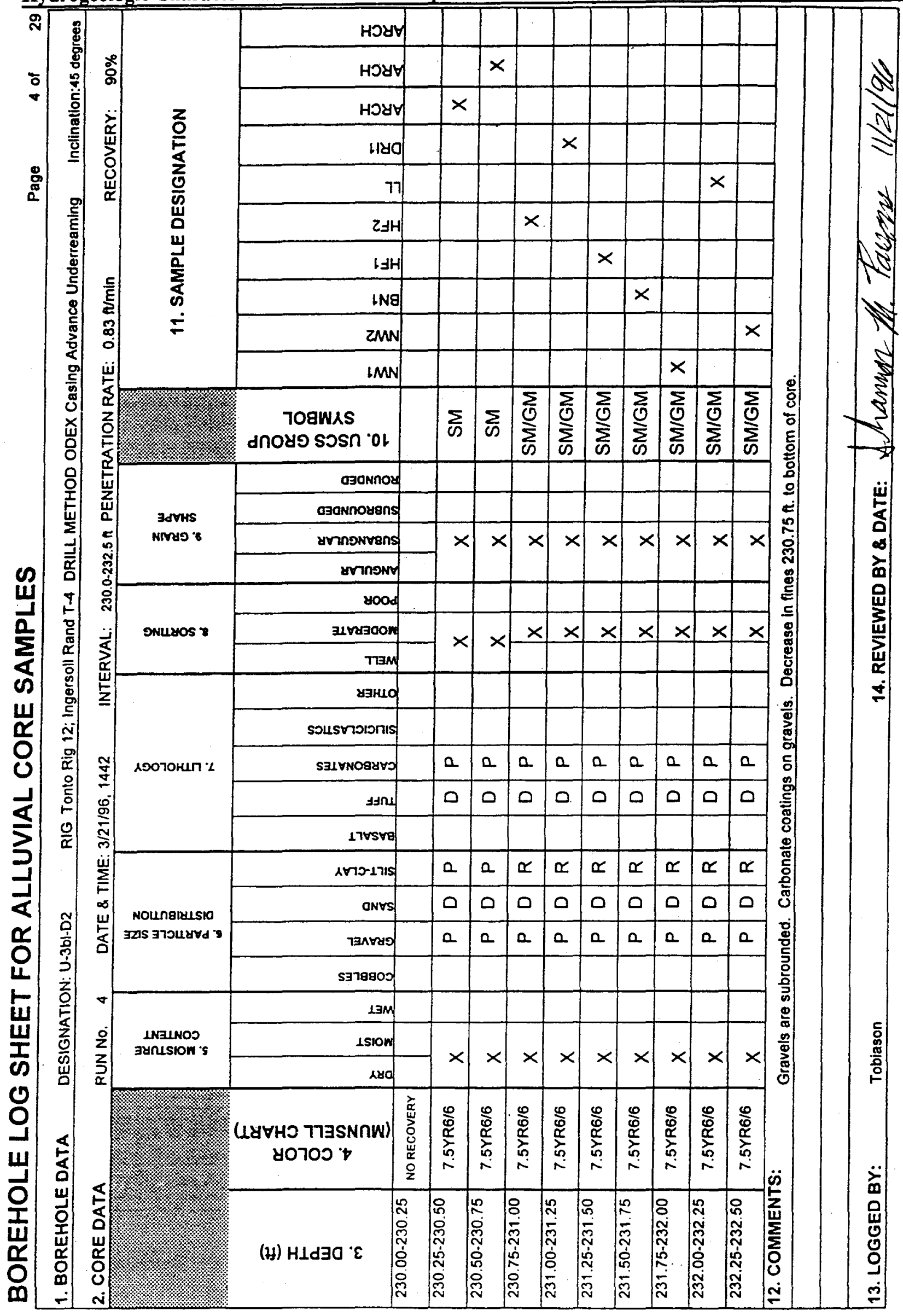




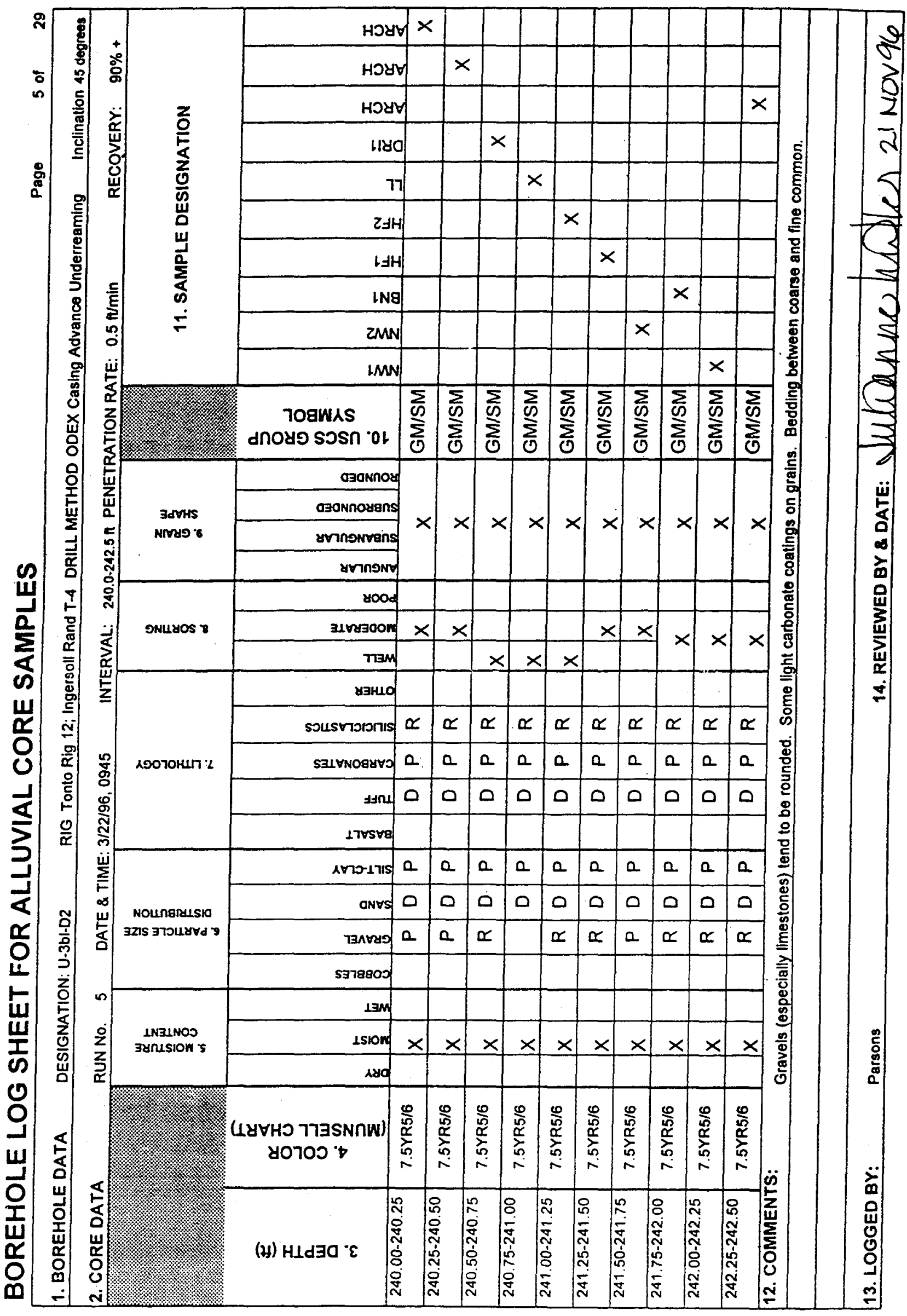




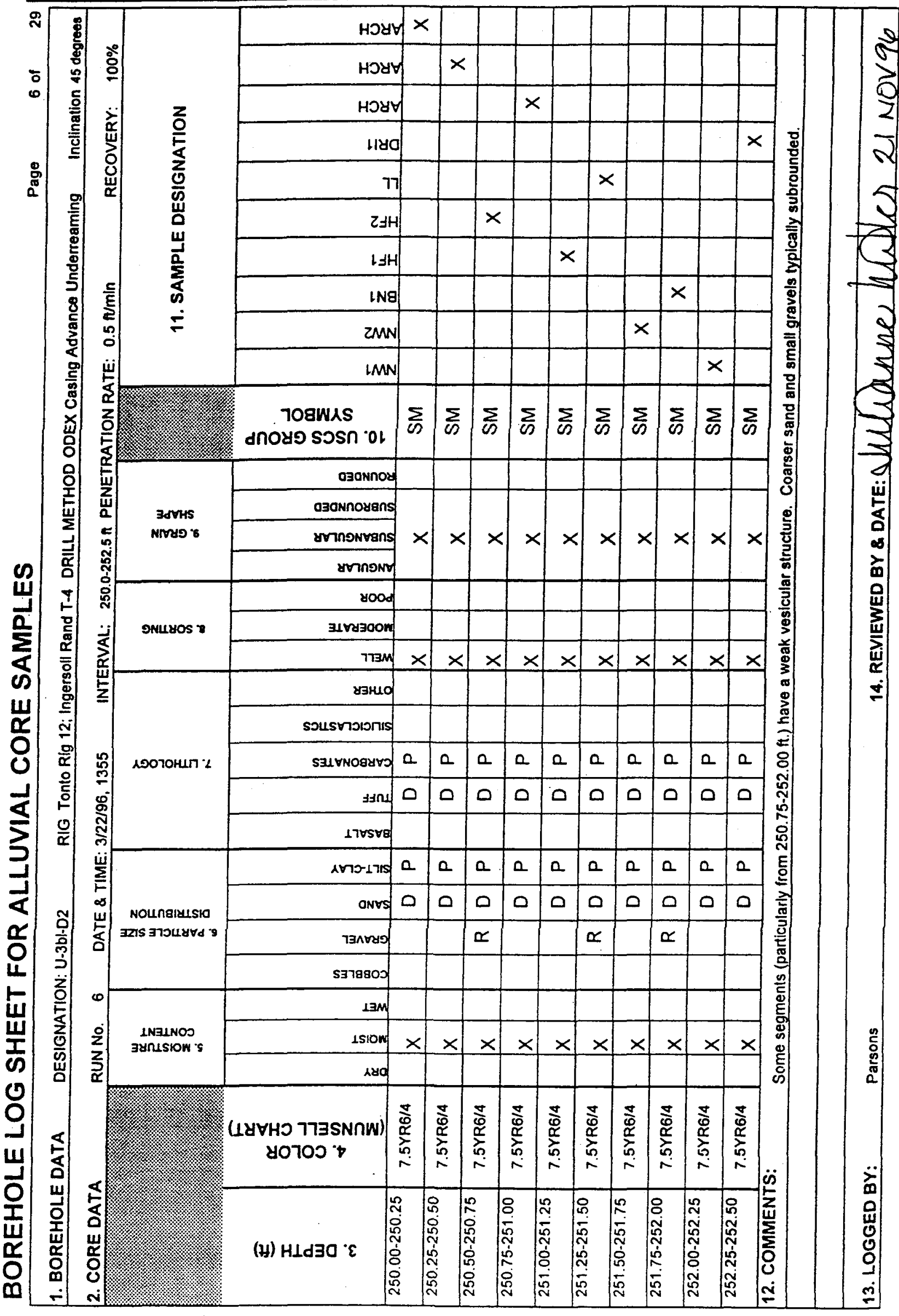




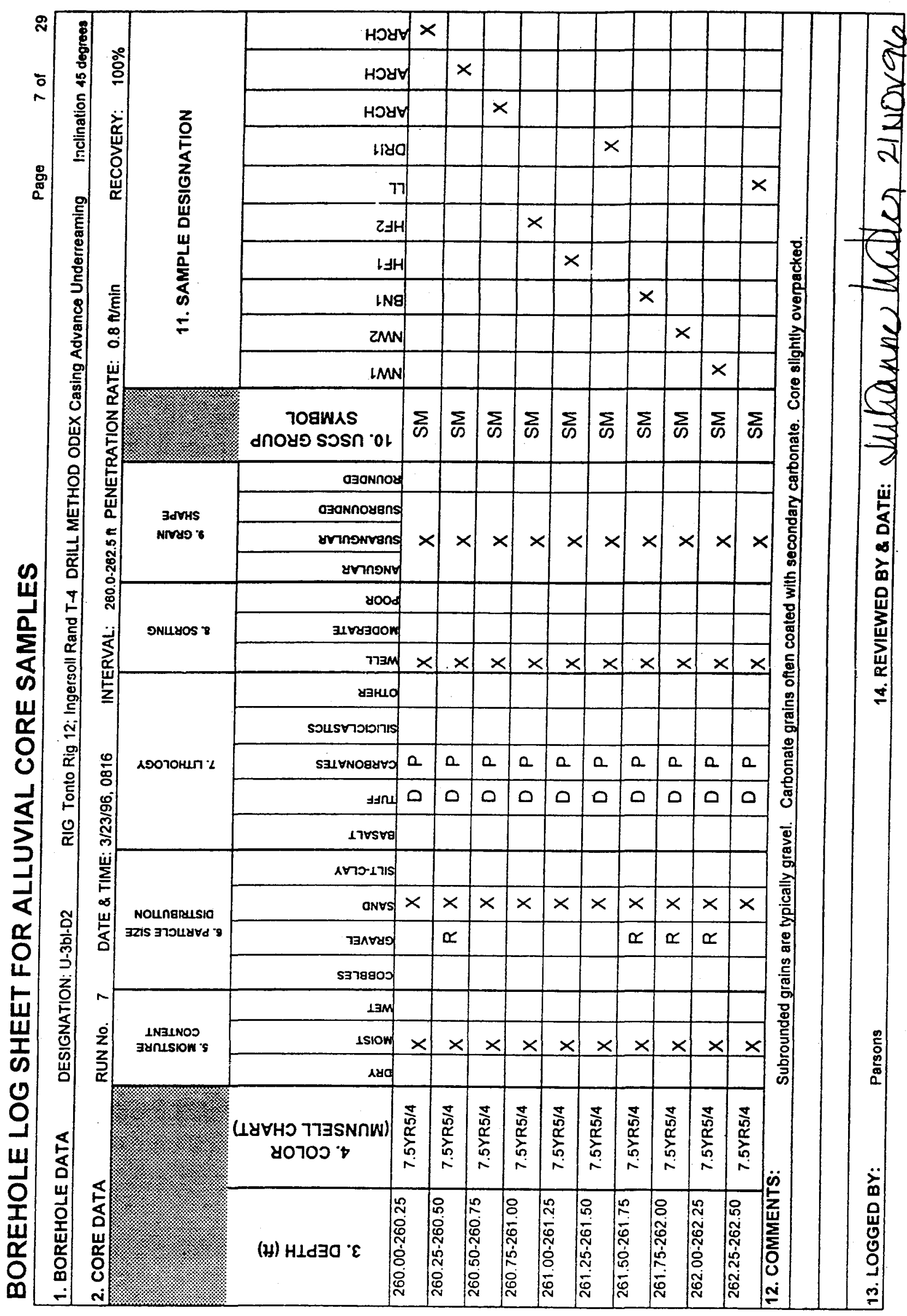




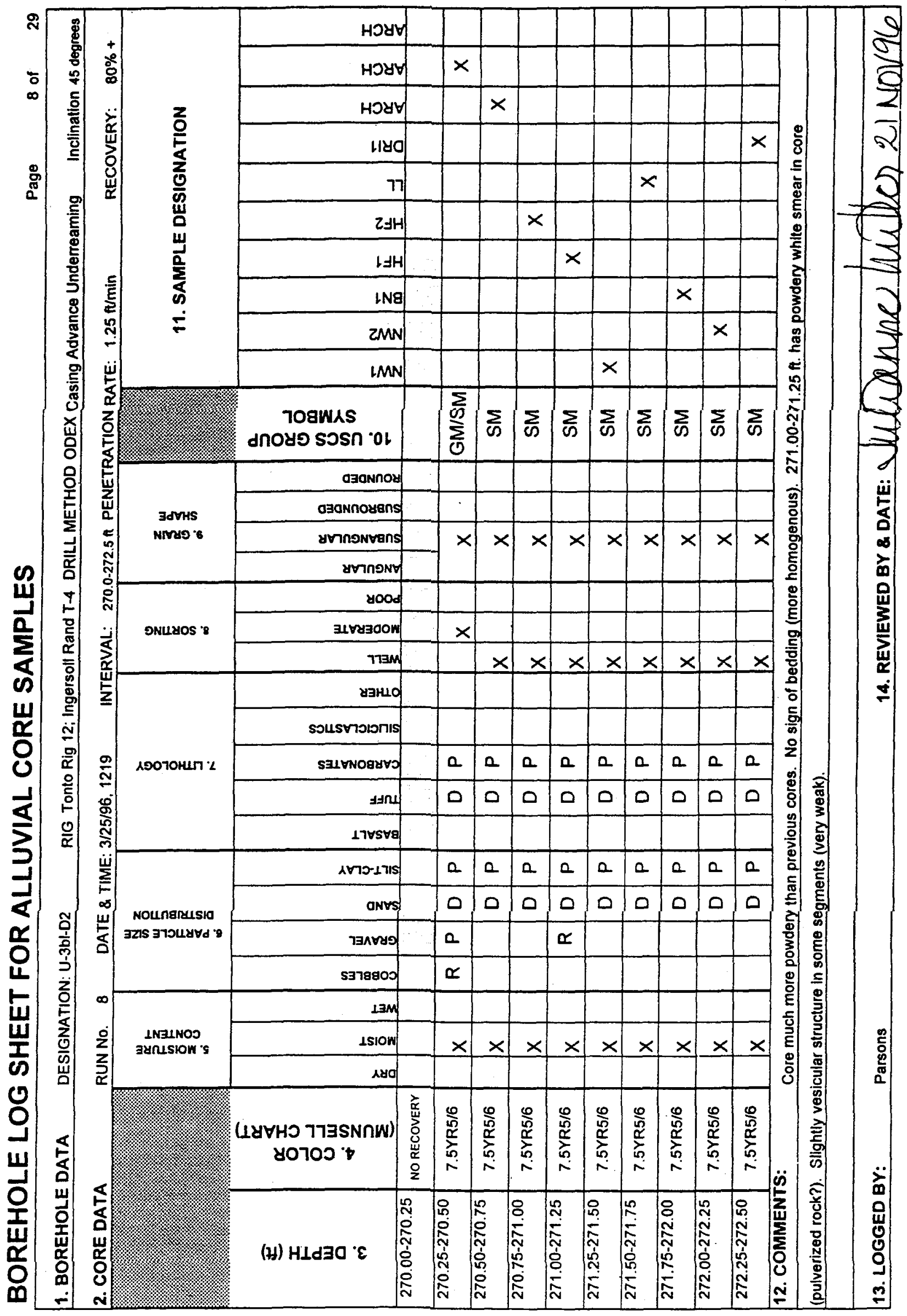




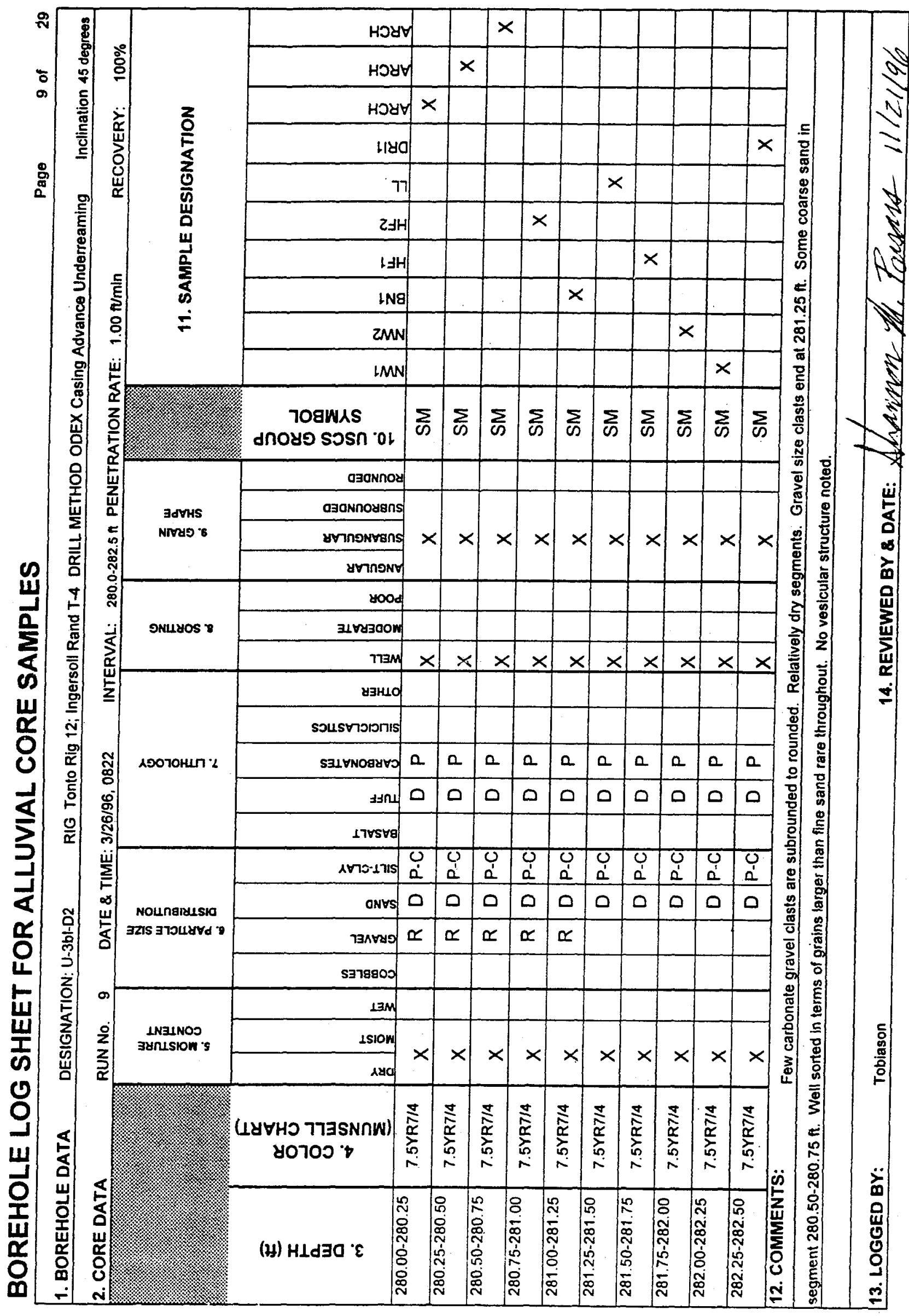




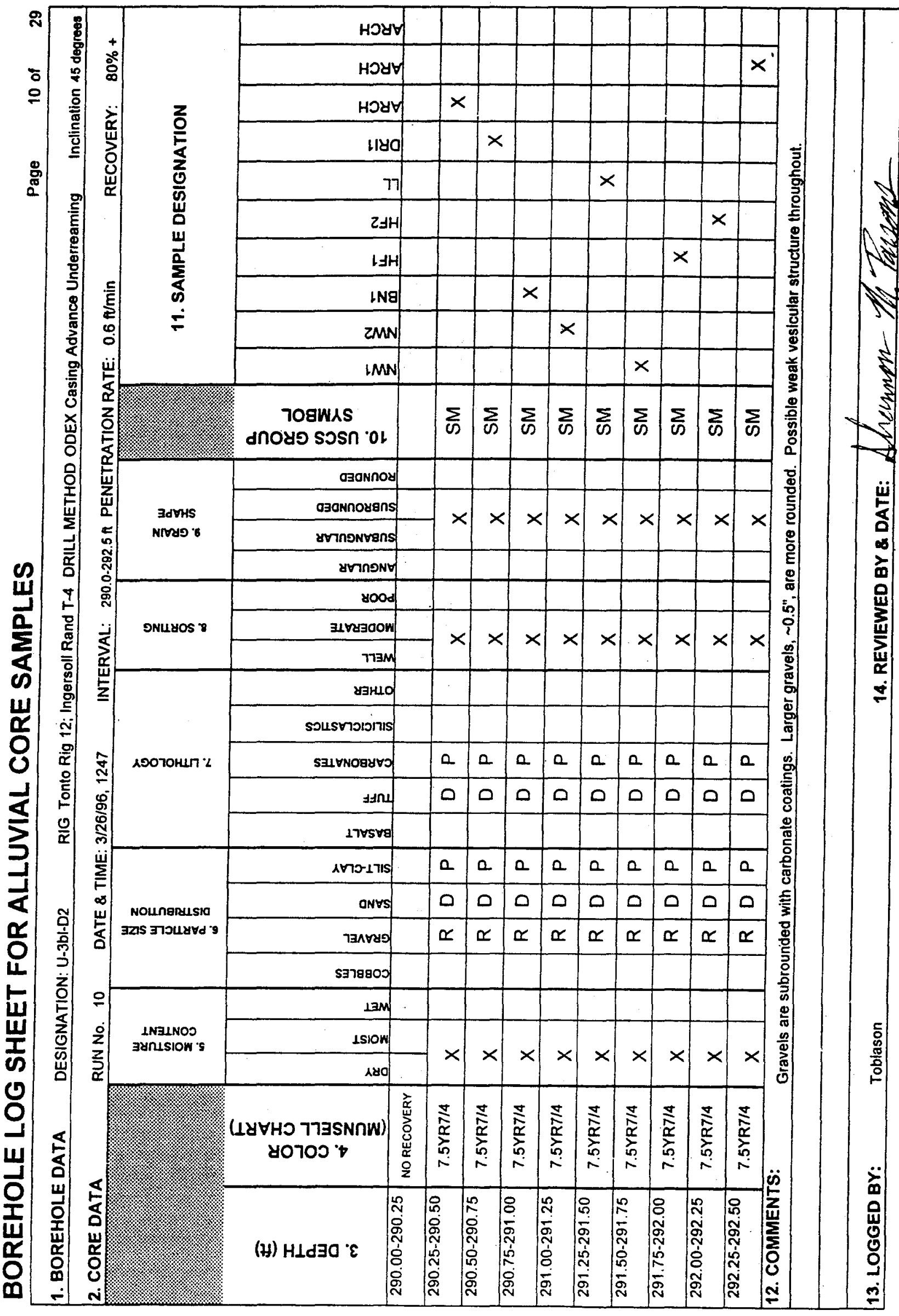




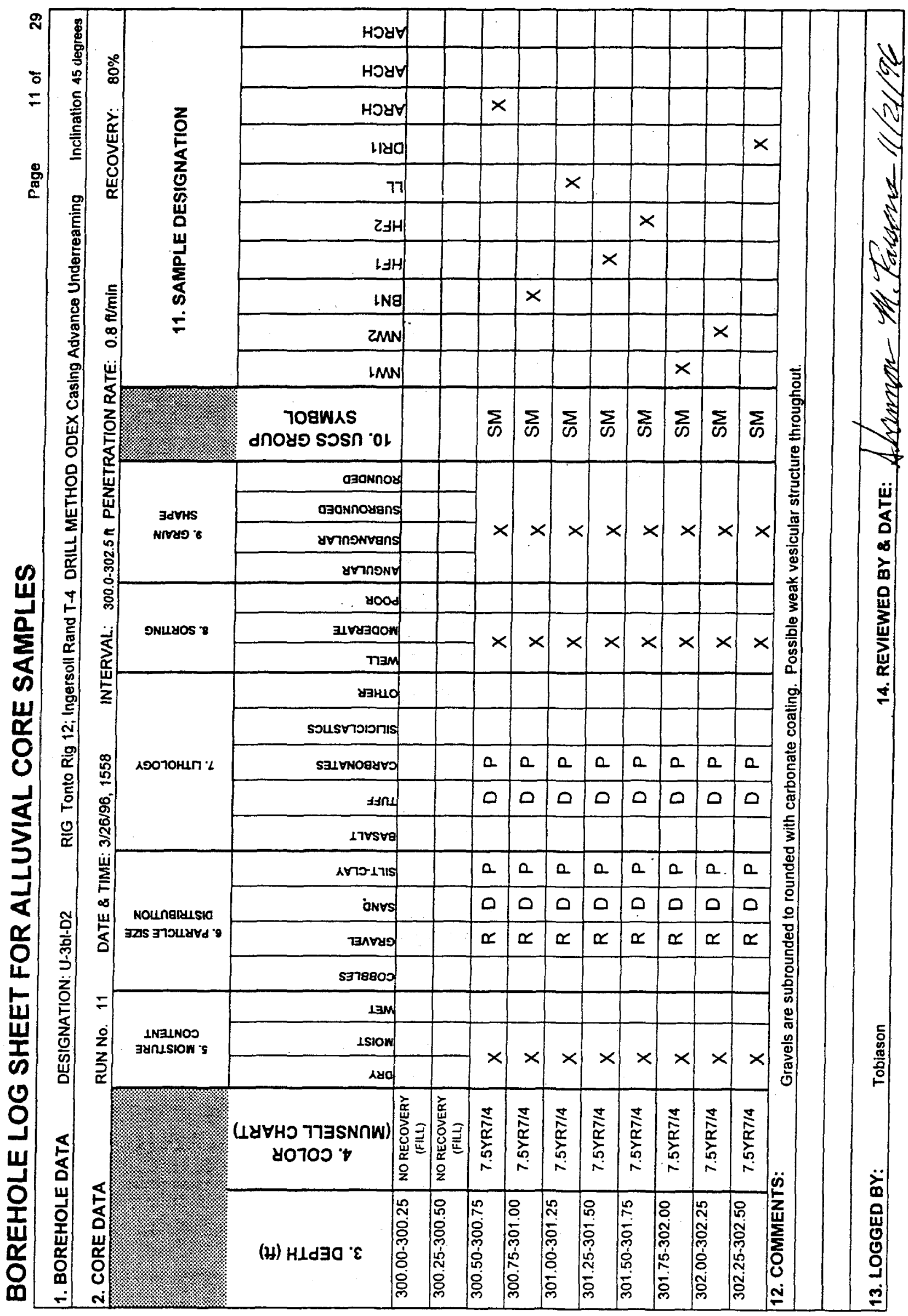




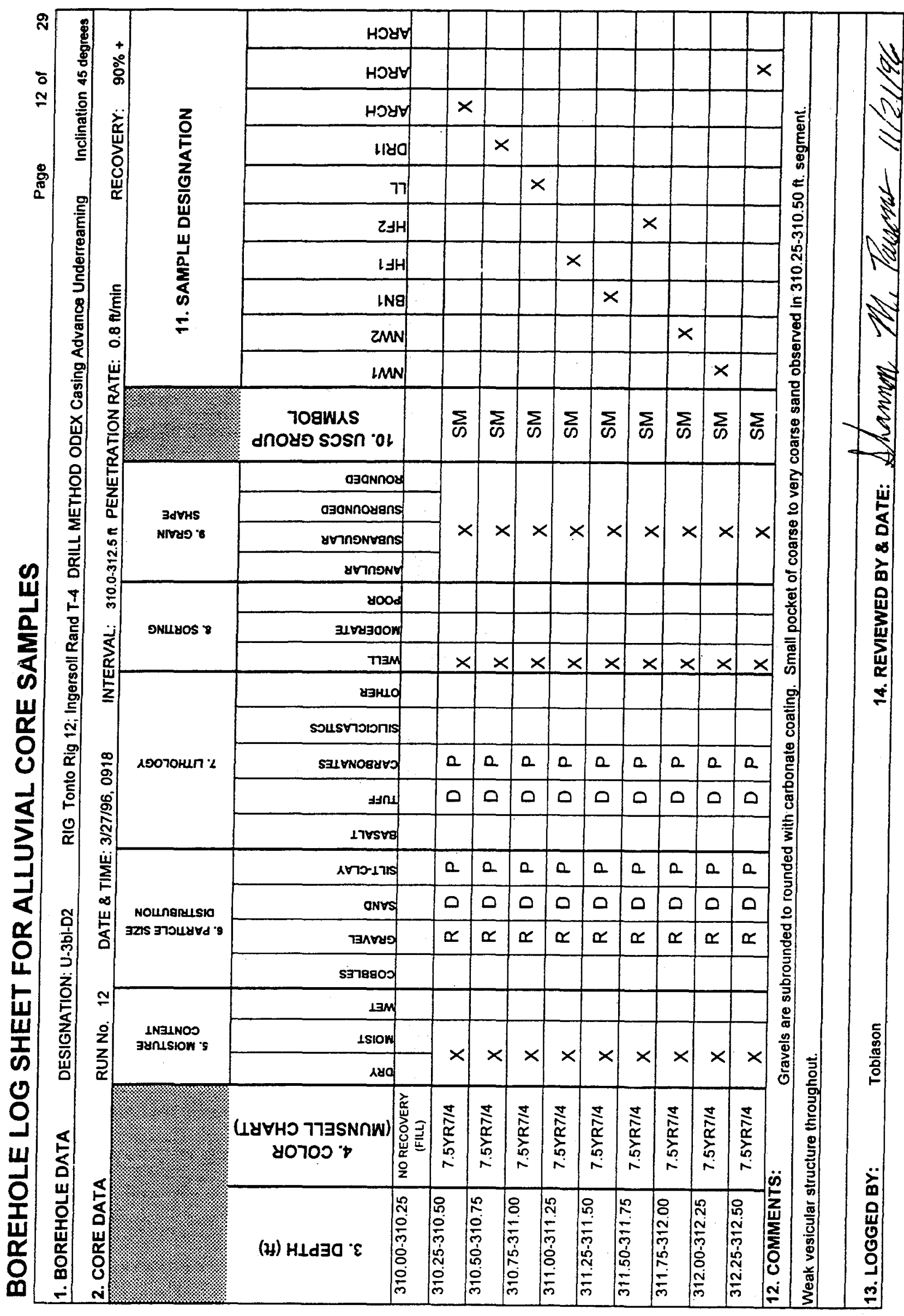


Hydrogeologic Characterization of U-3bl Collapse Zone

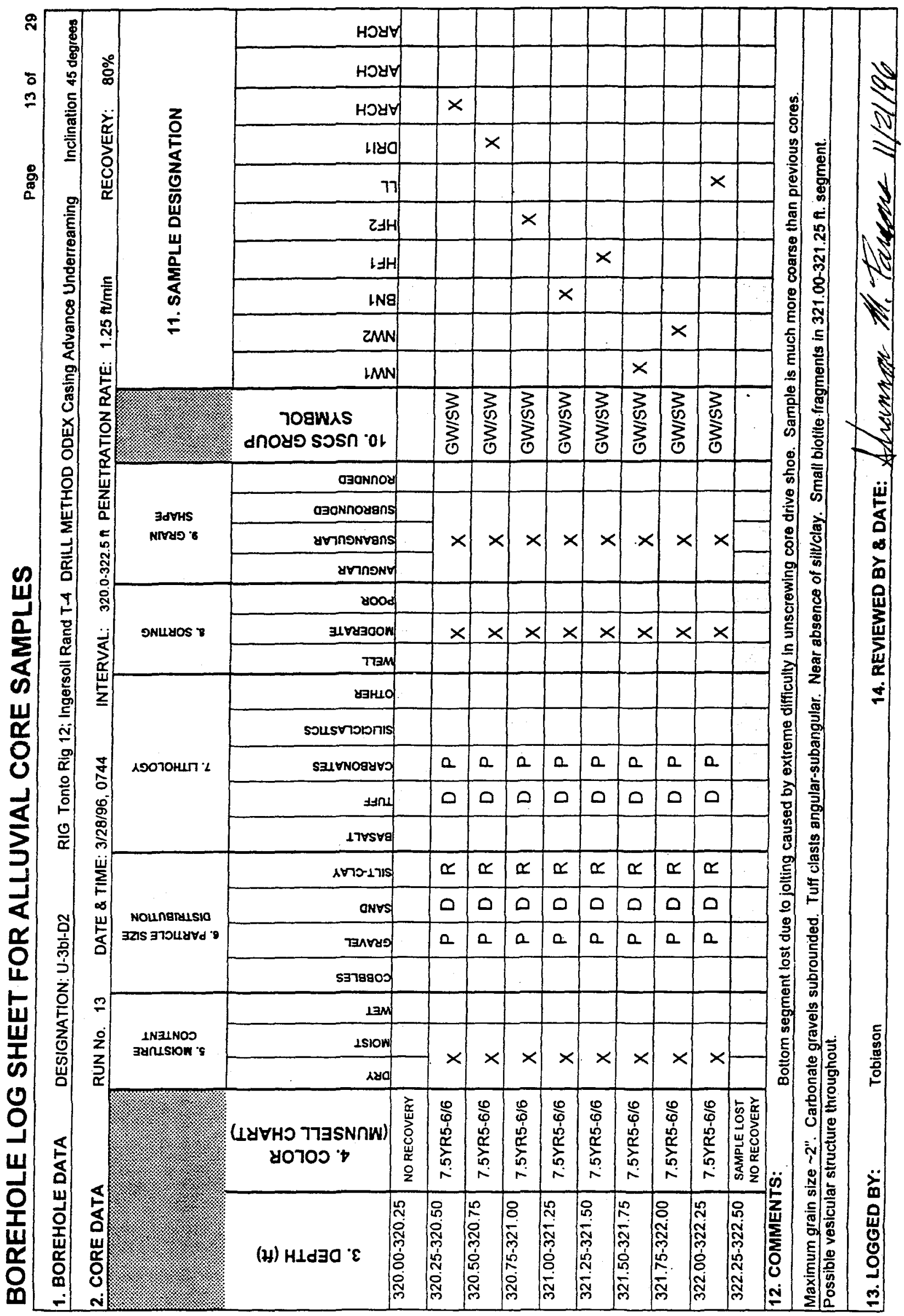




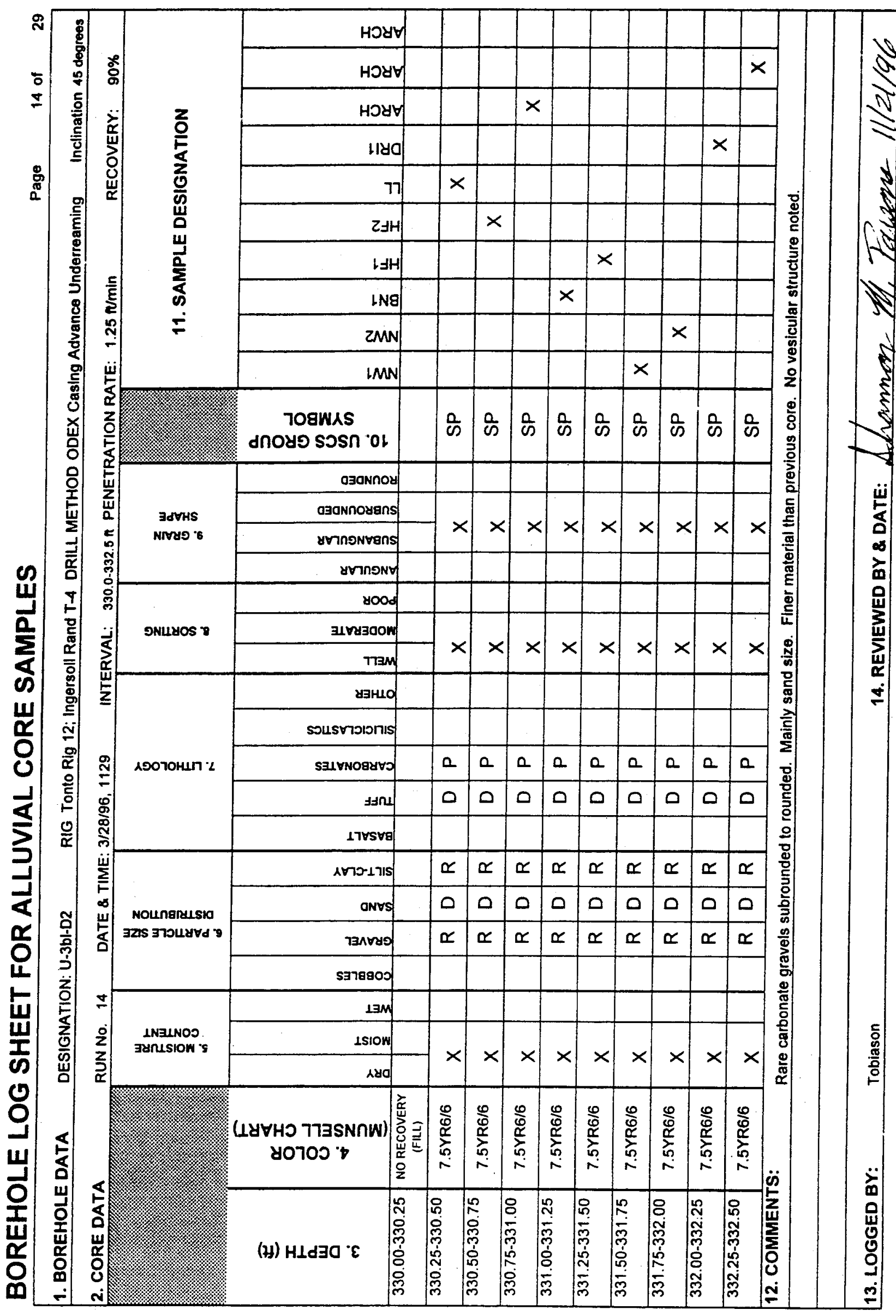




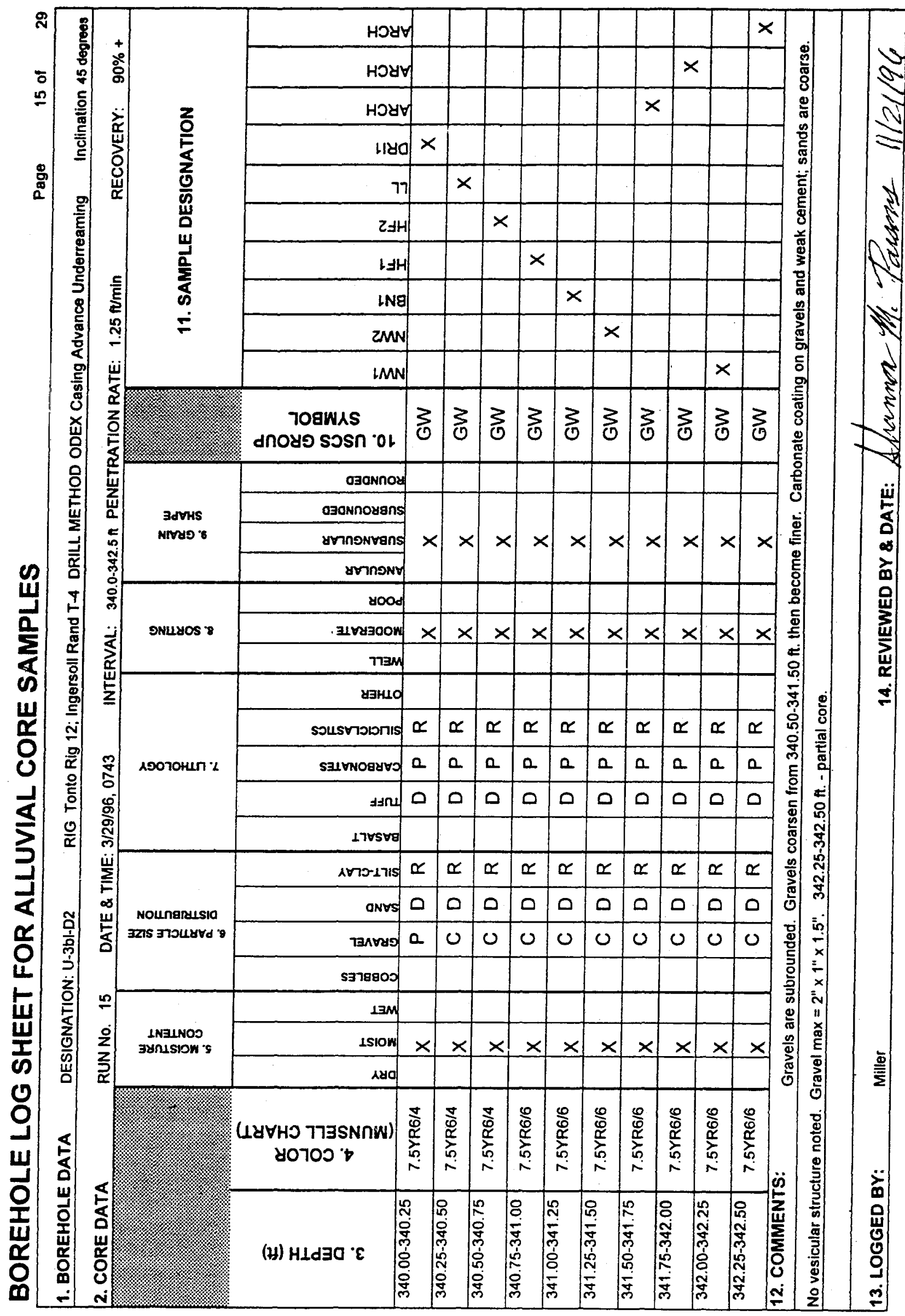




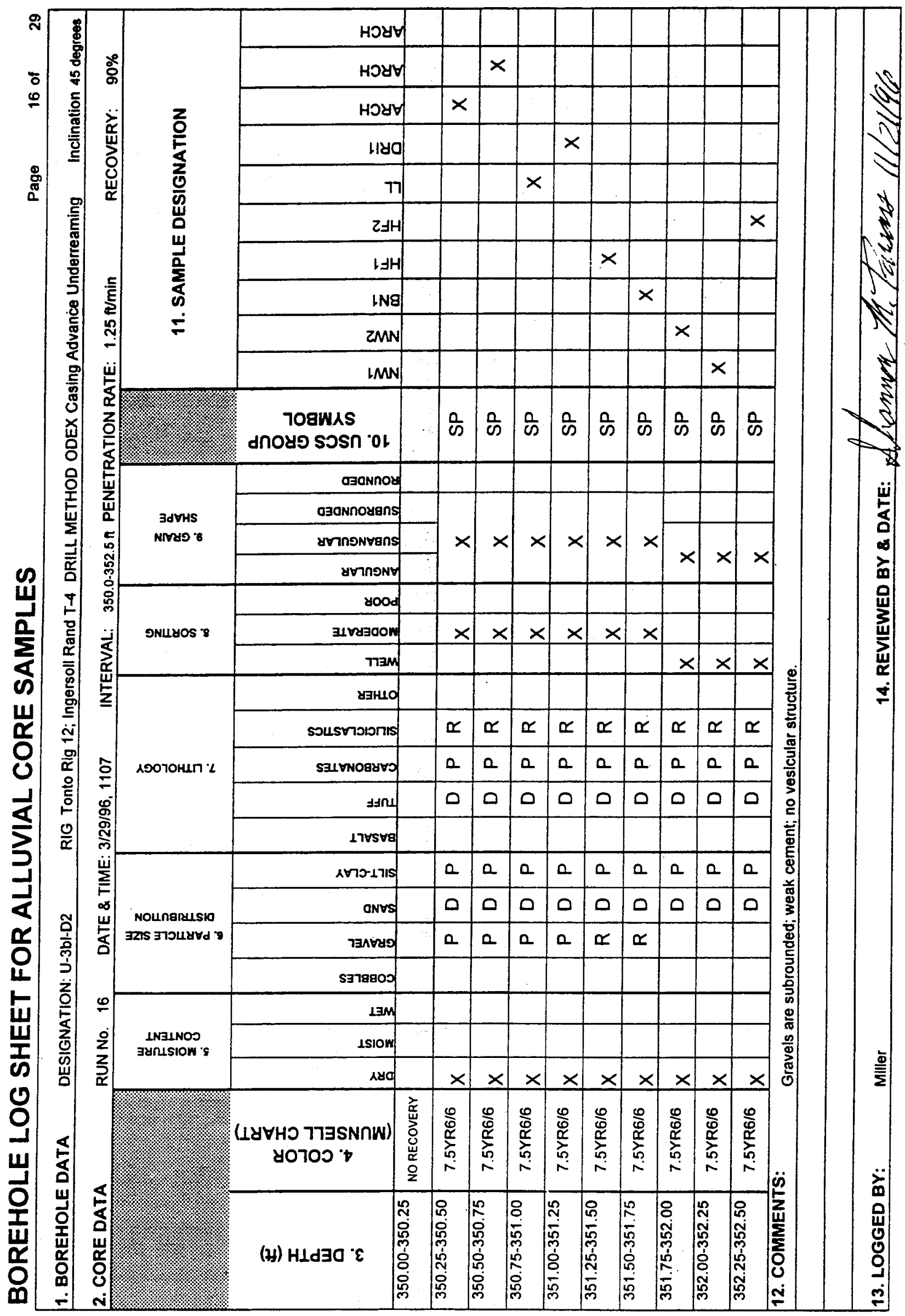




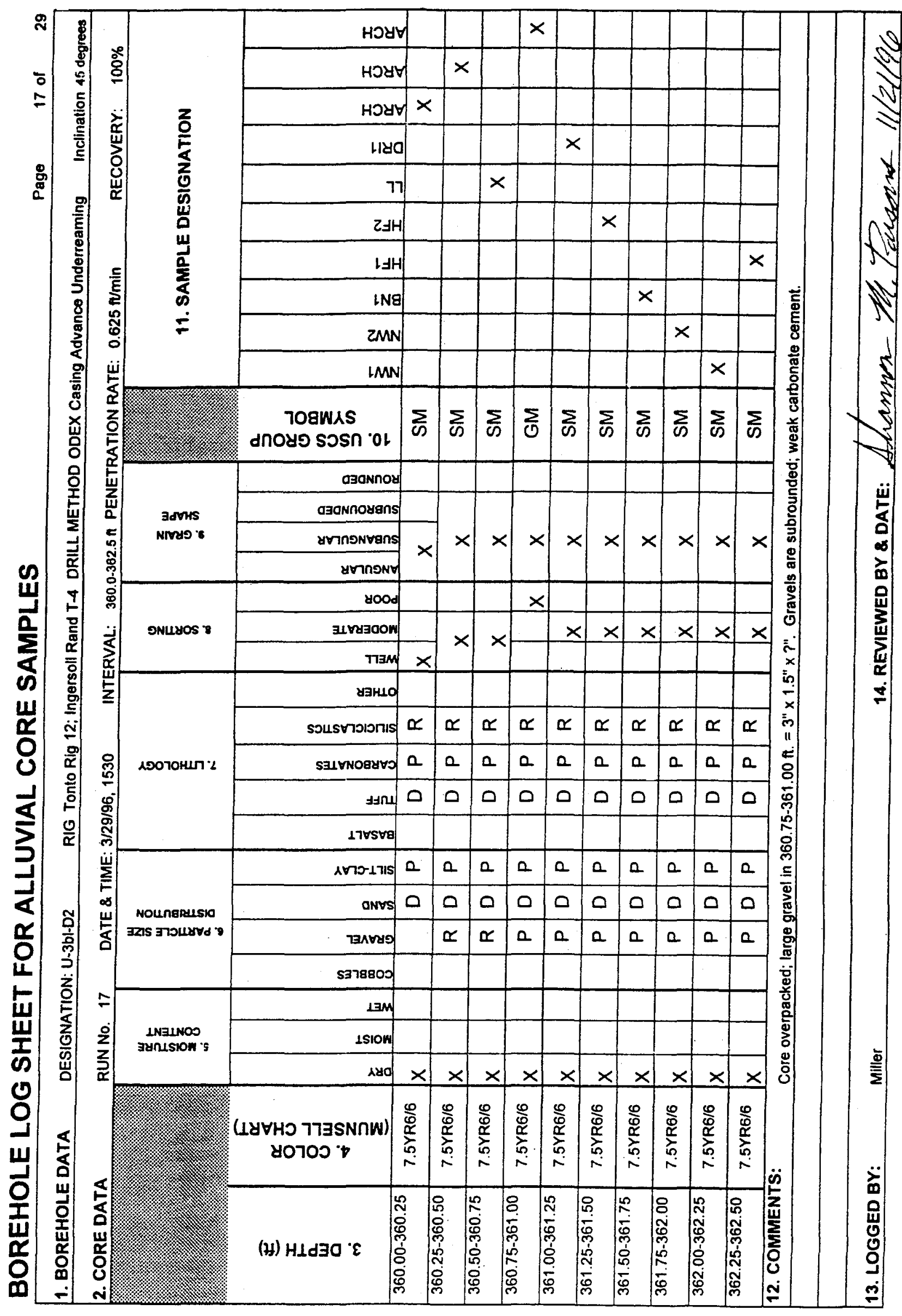




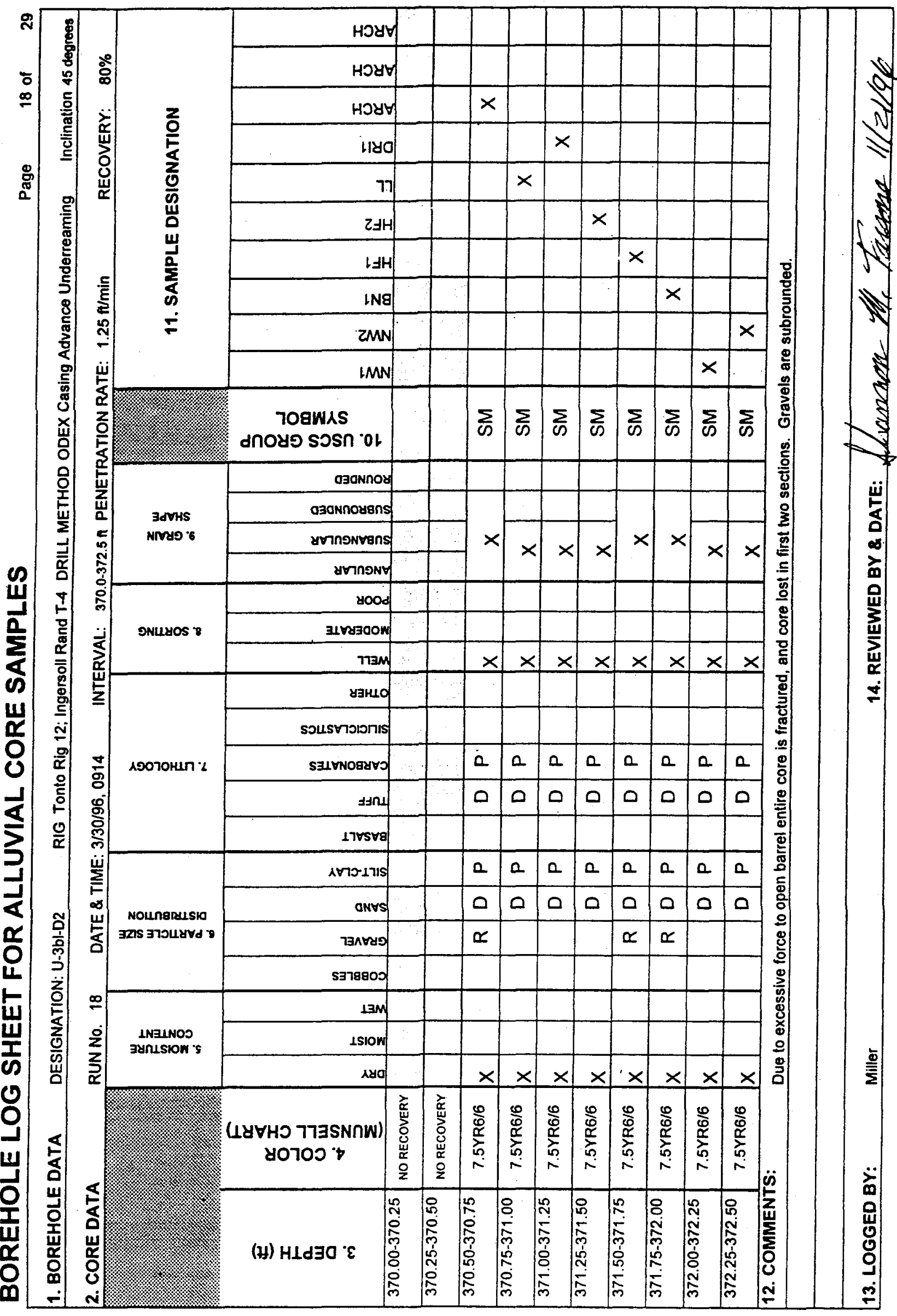




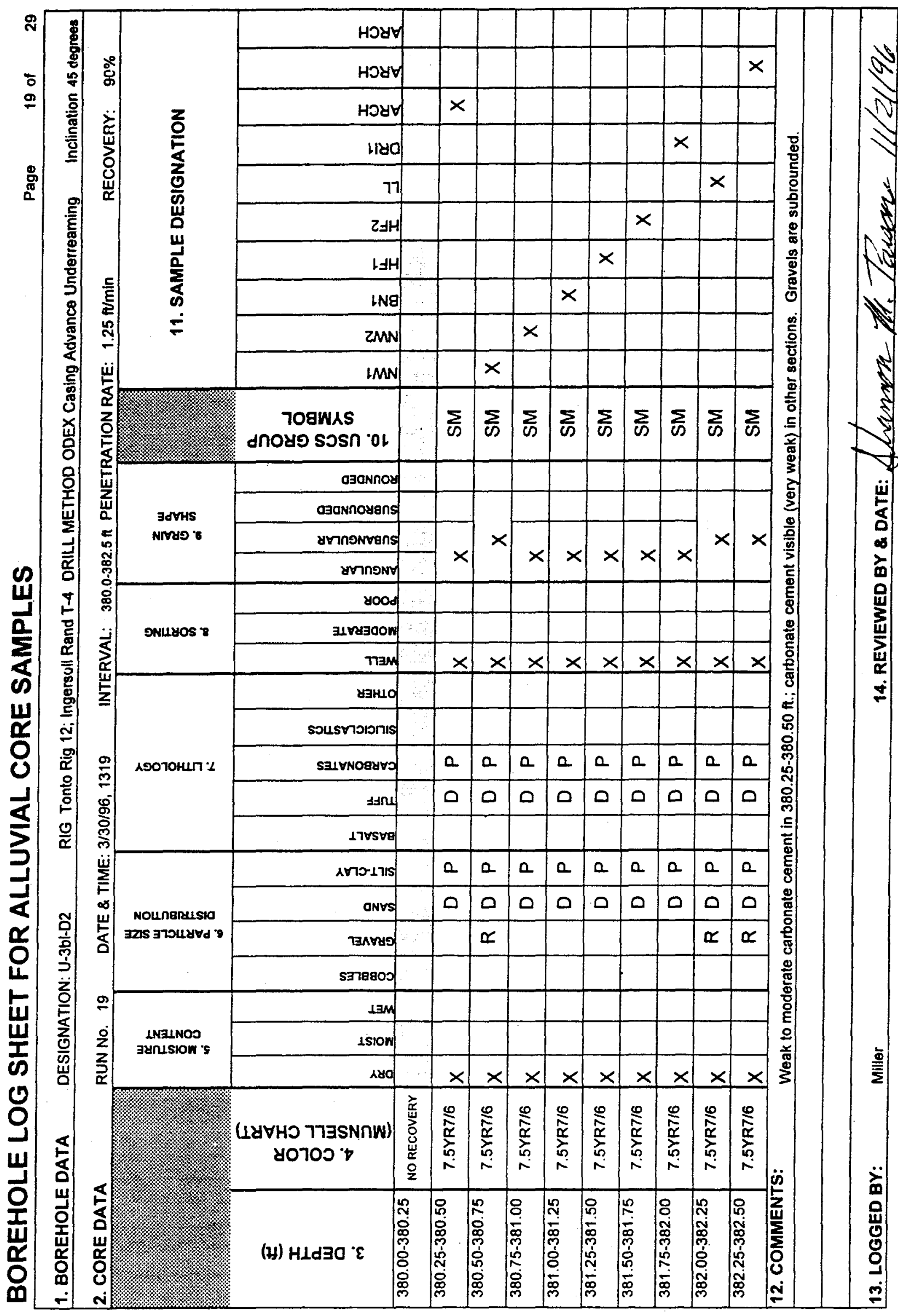




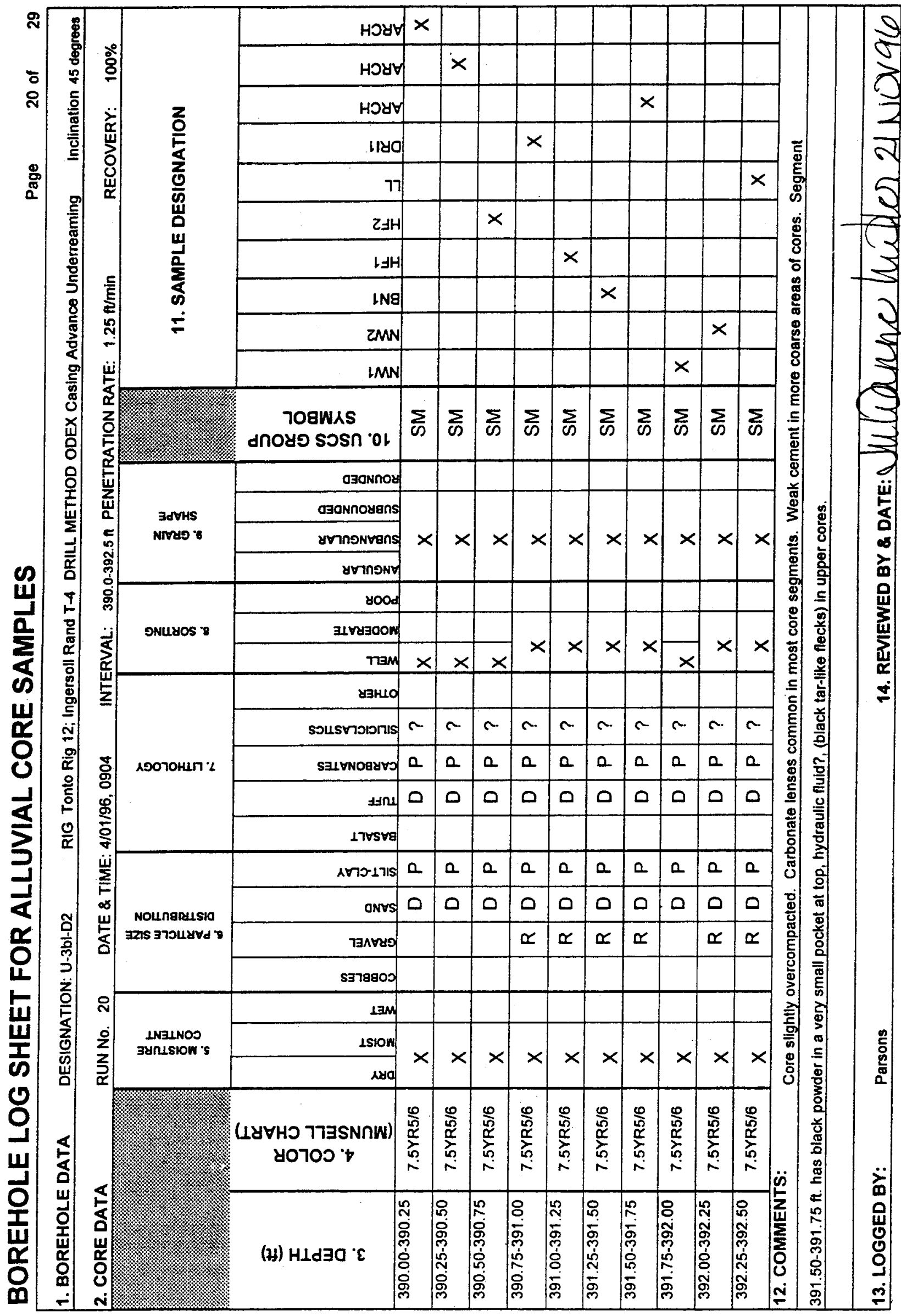




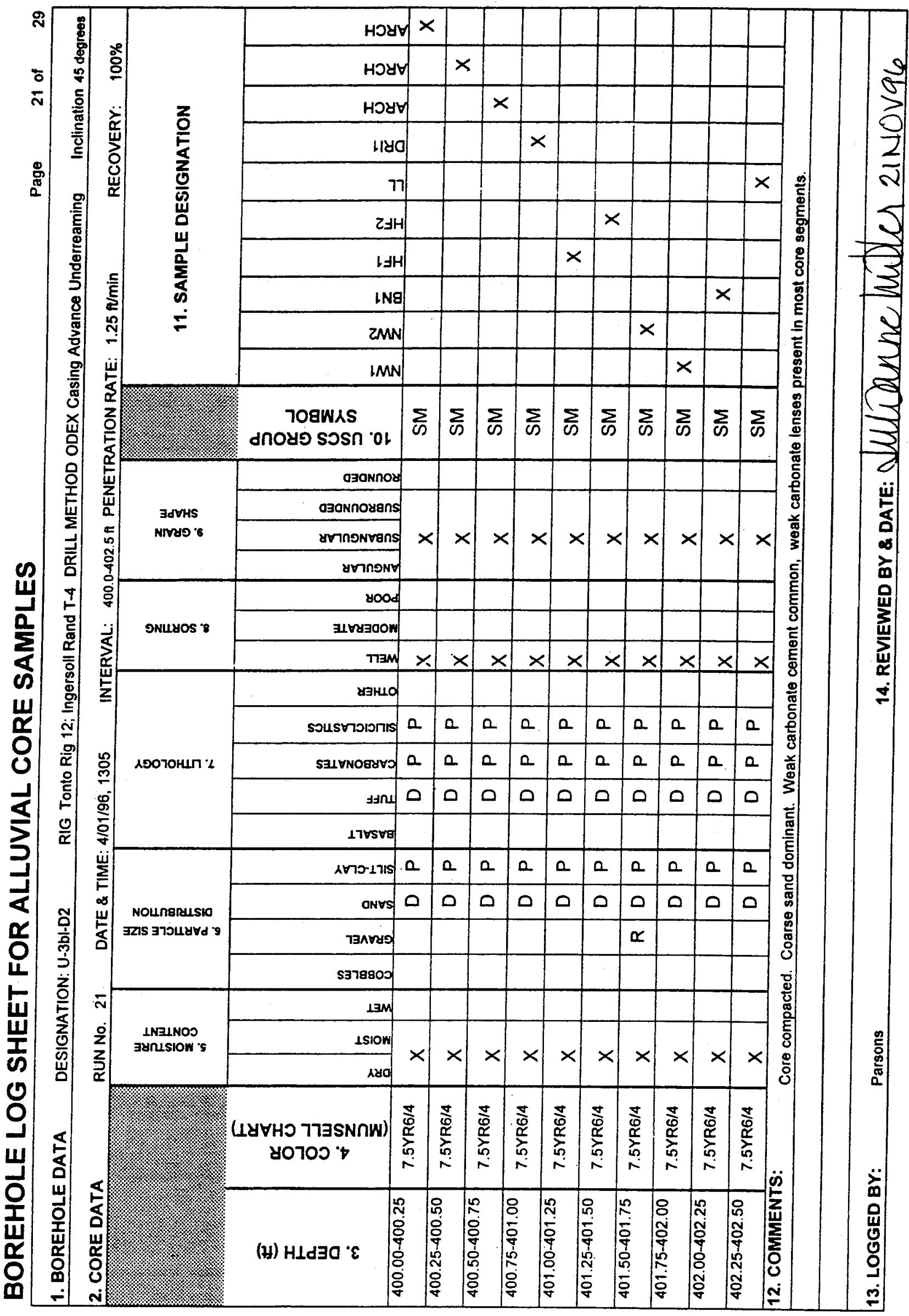




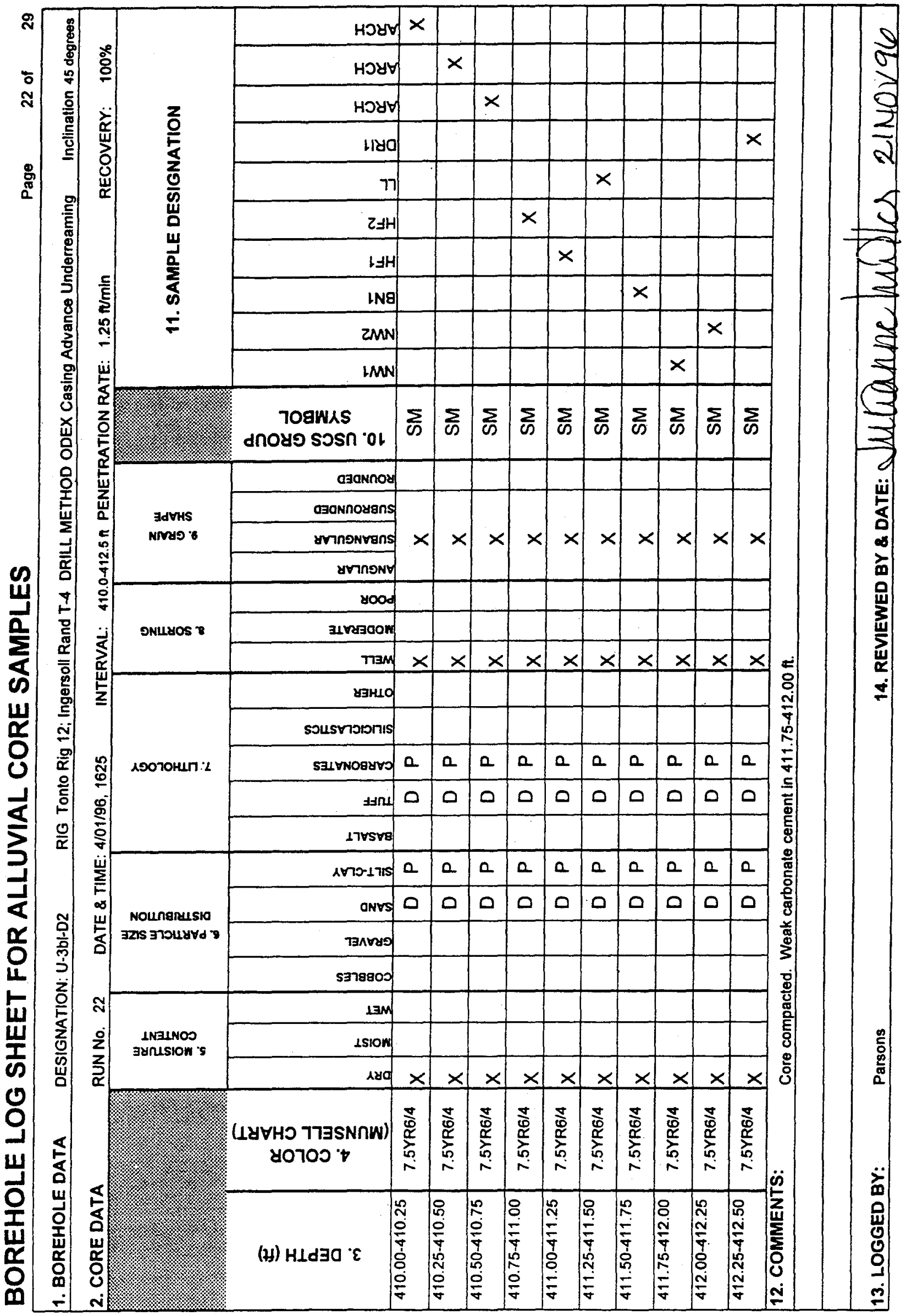




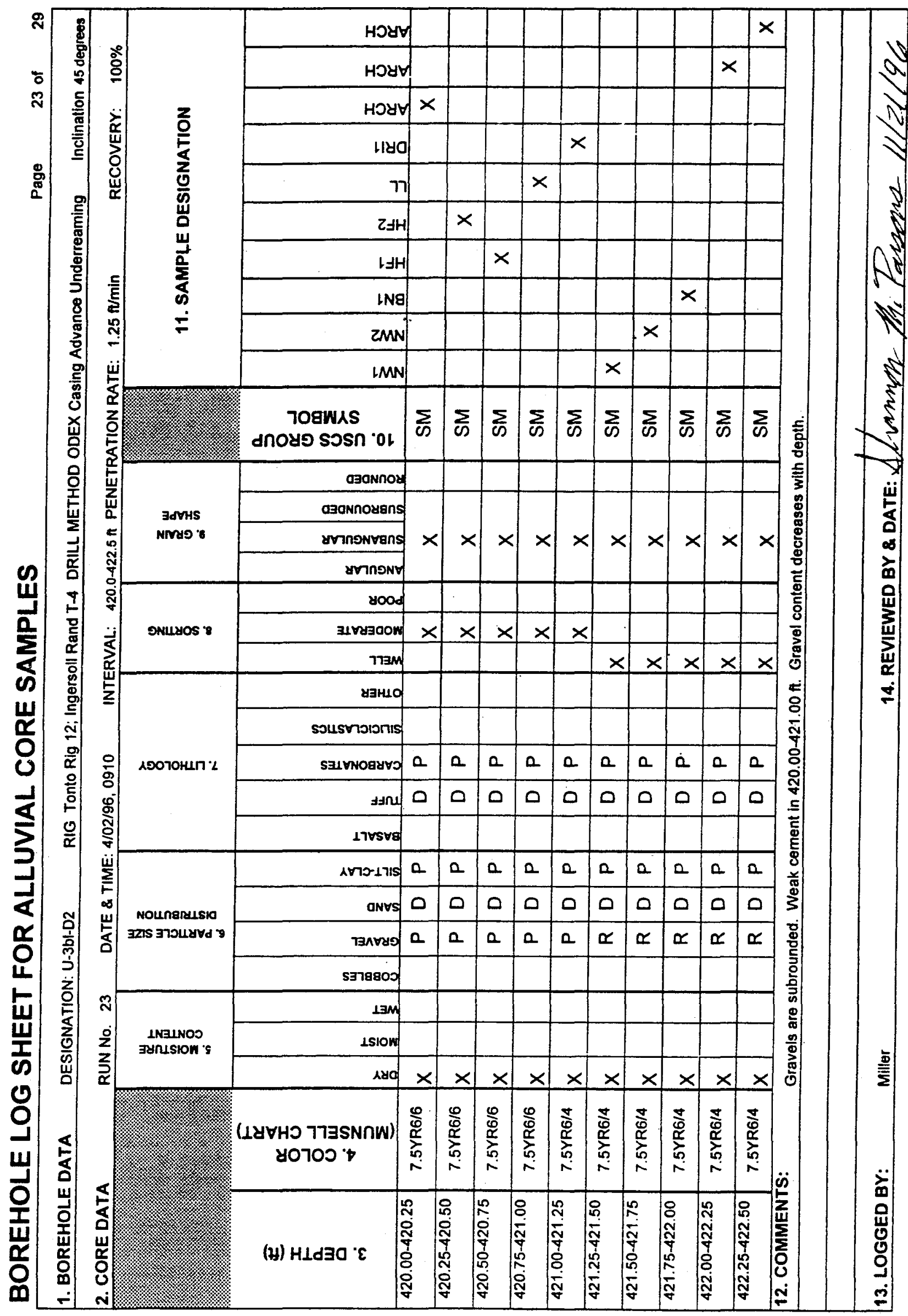




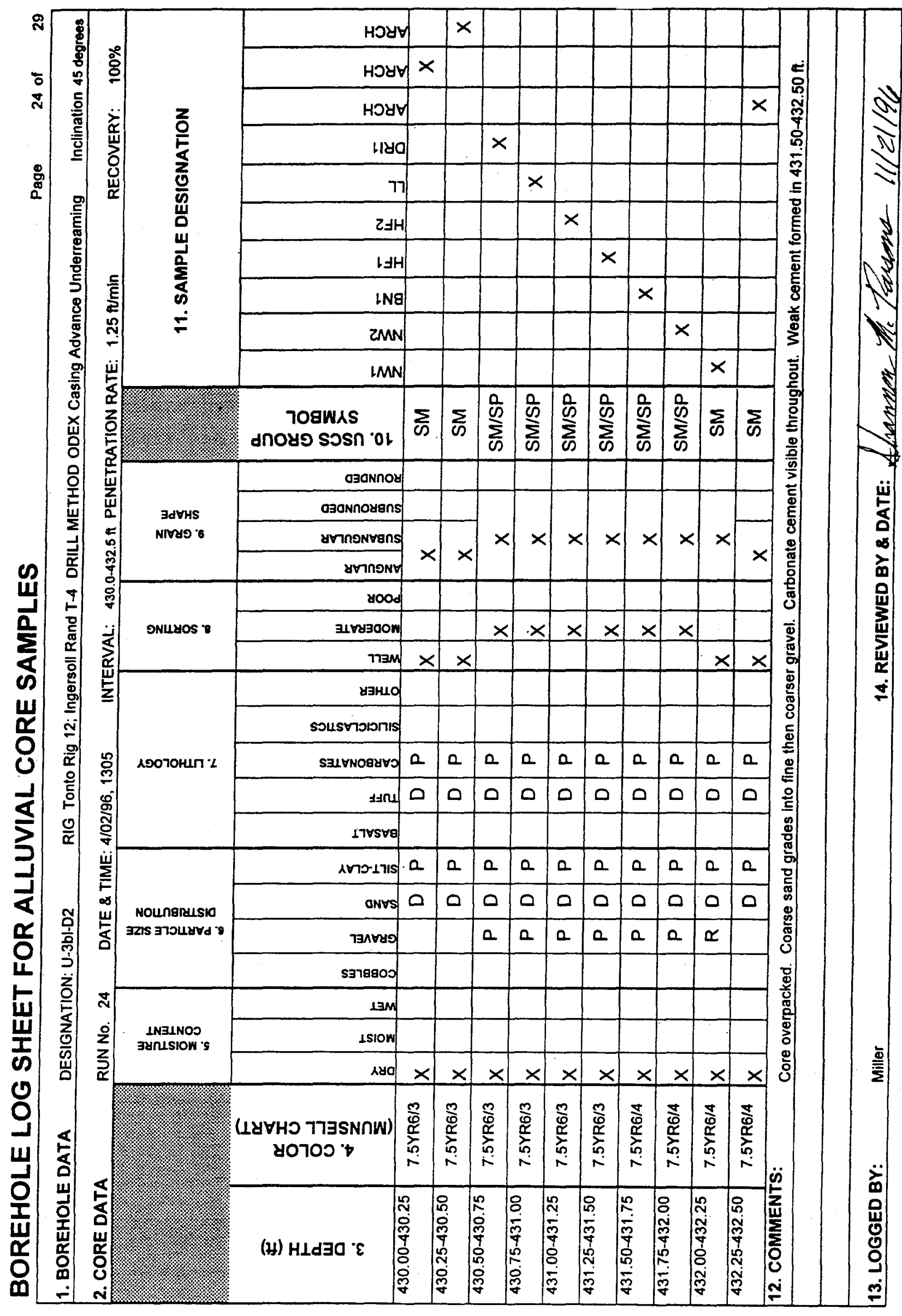




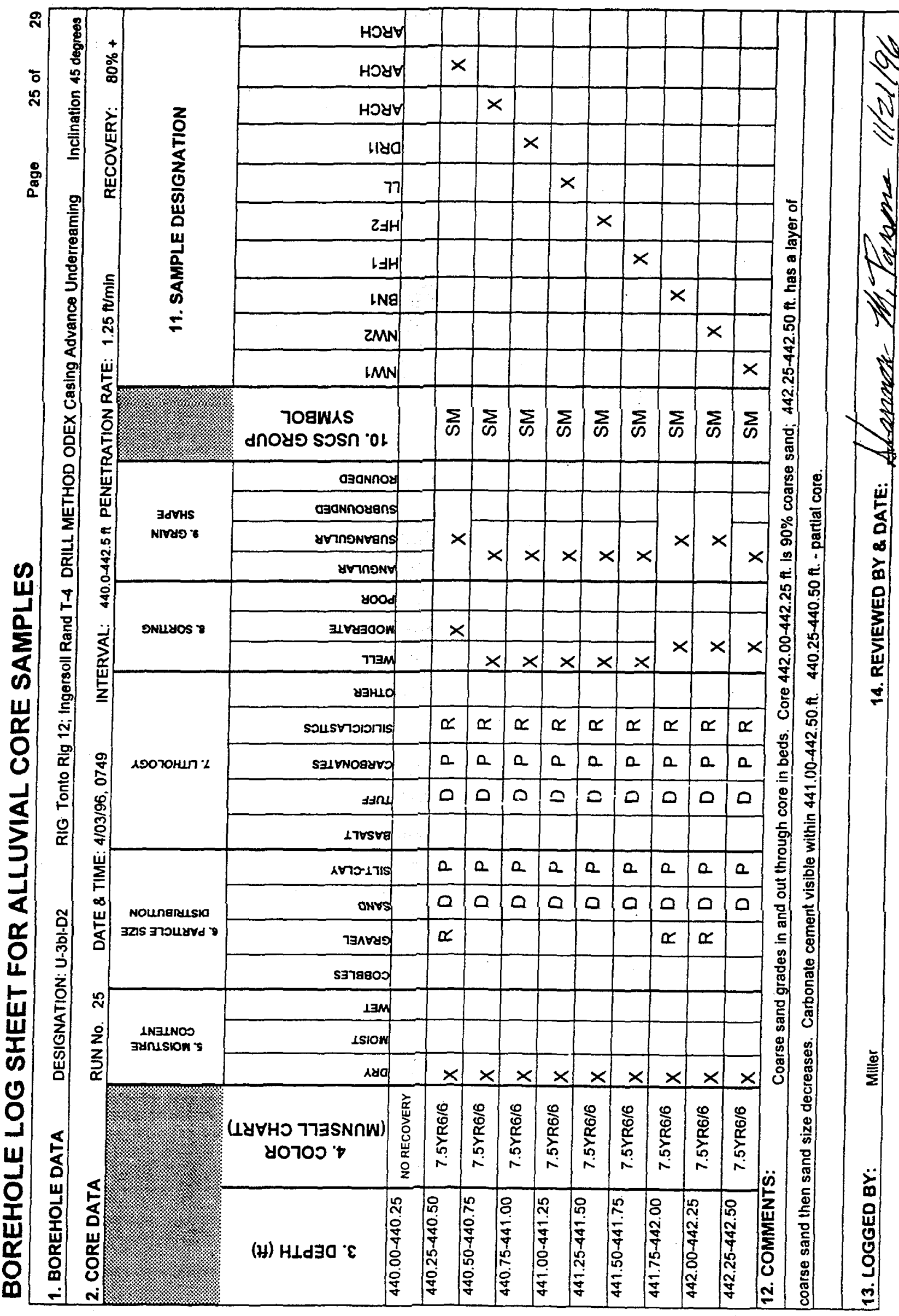




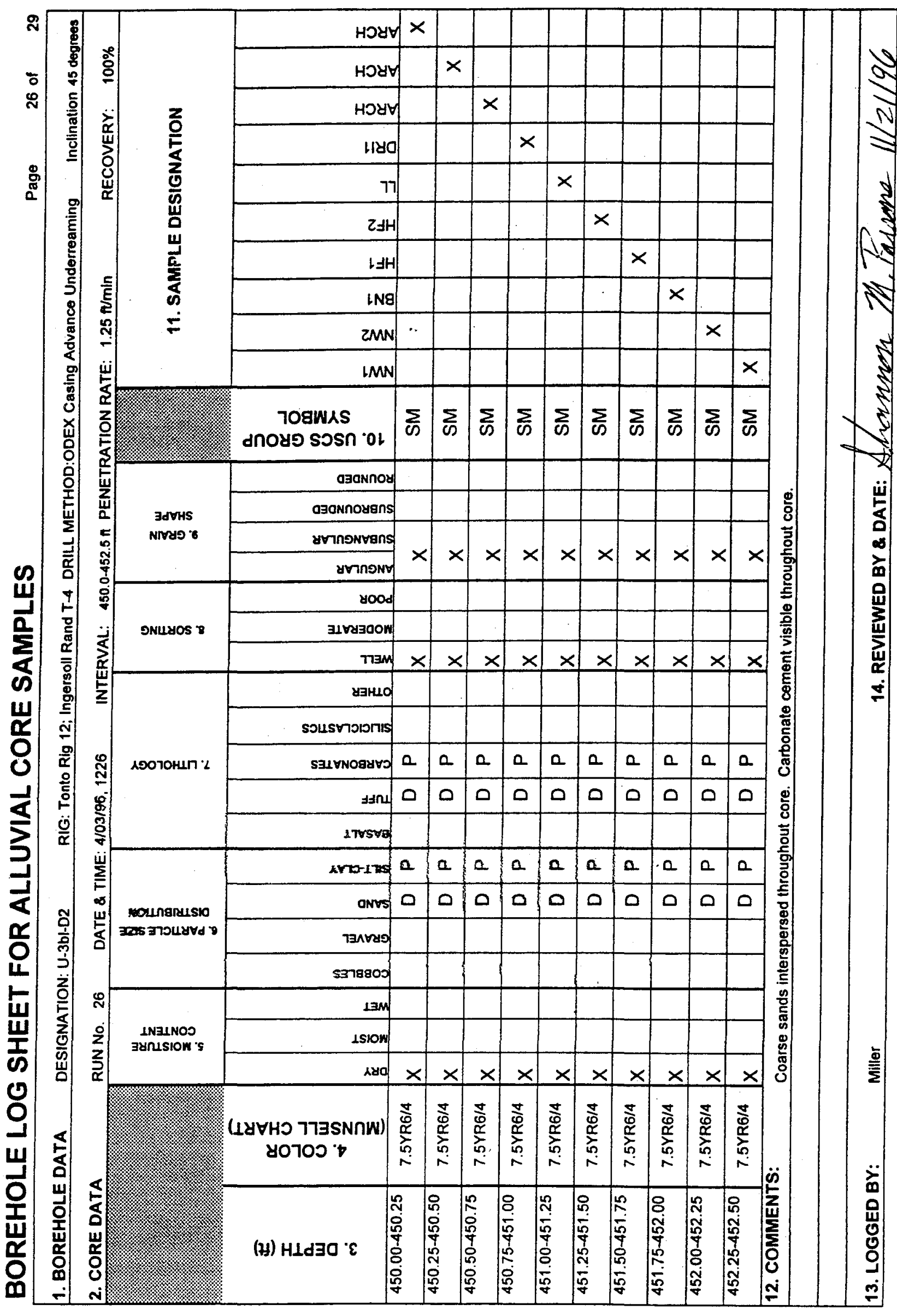




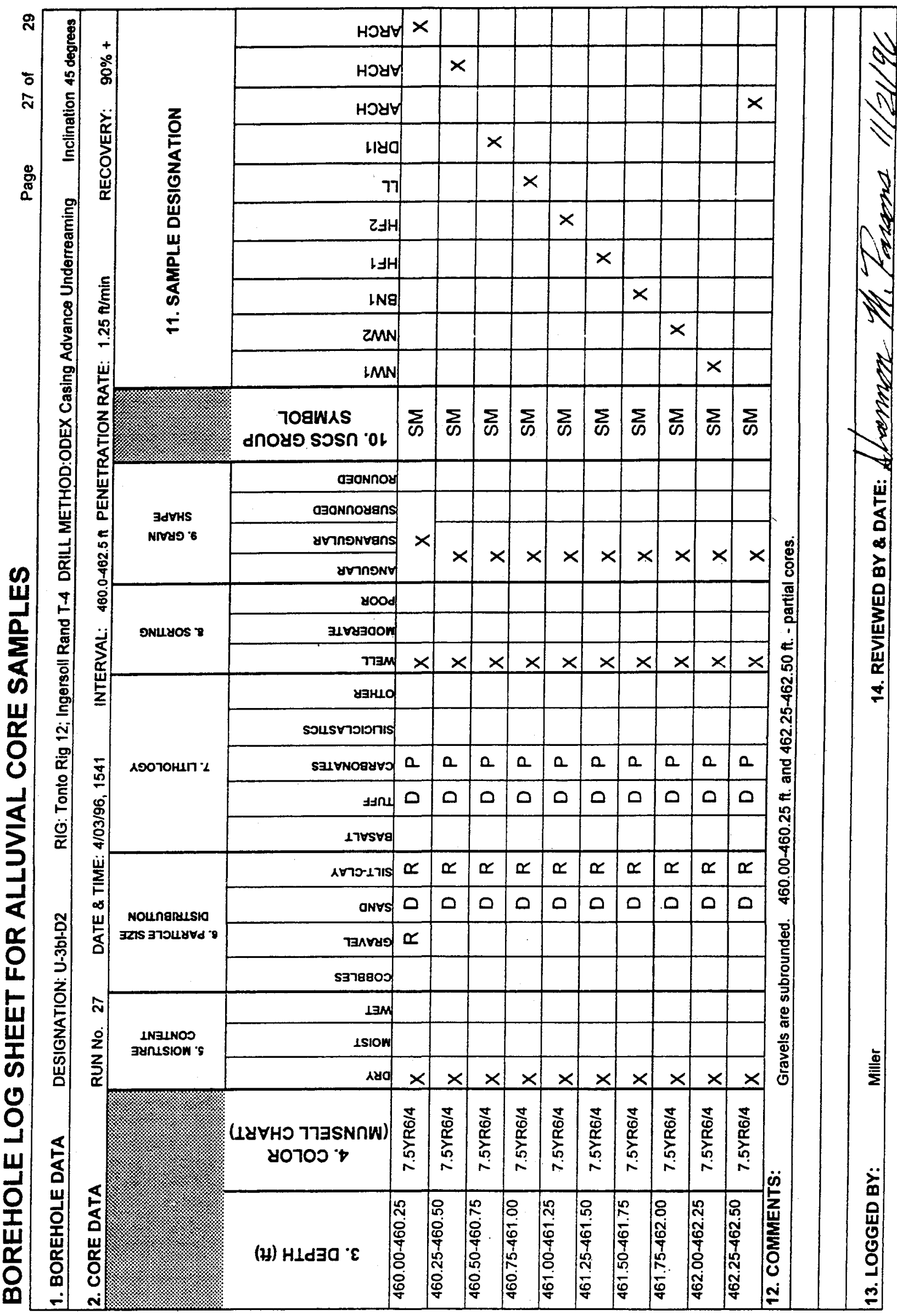




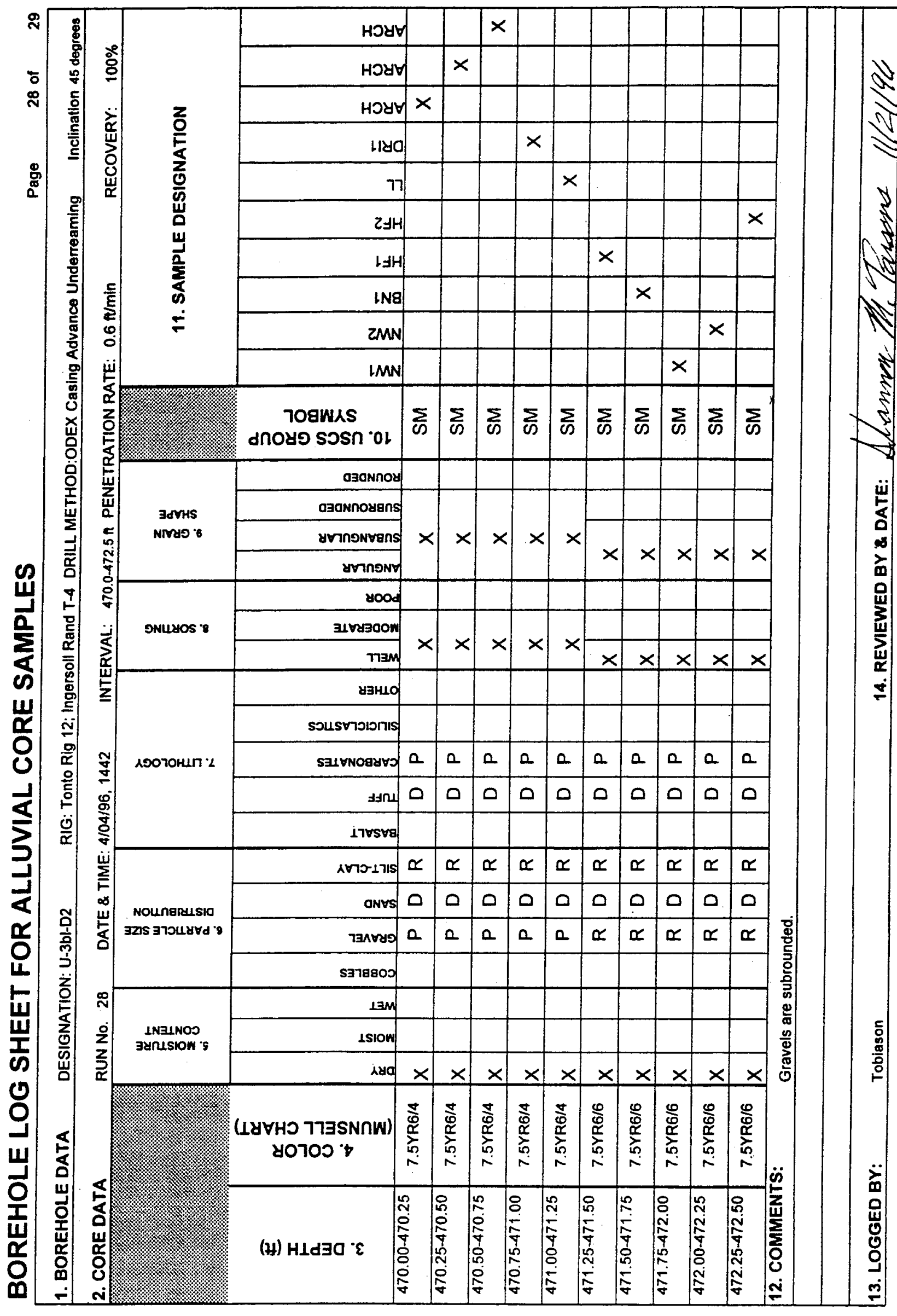




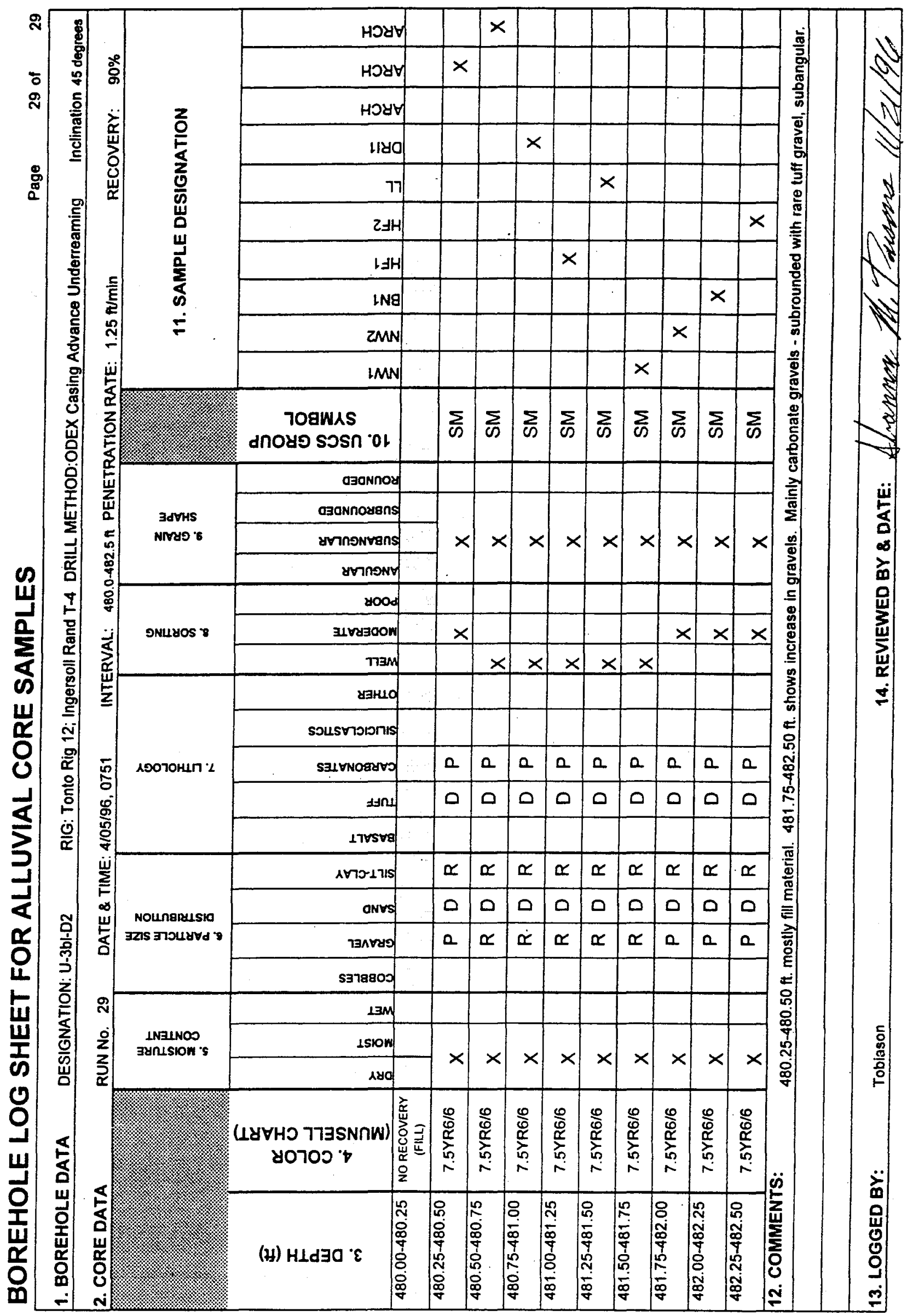




\section{ATTACHMENT C}

\section{CHARACTERIZATION DATA FIGURES}

FOR BOREHOLE U-3bl-D2 


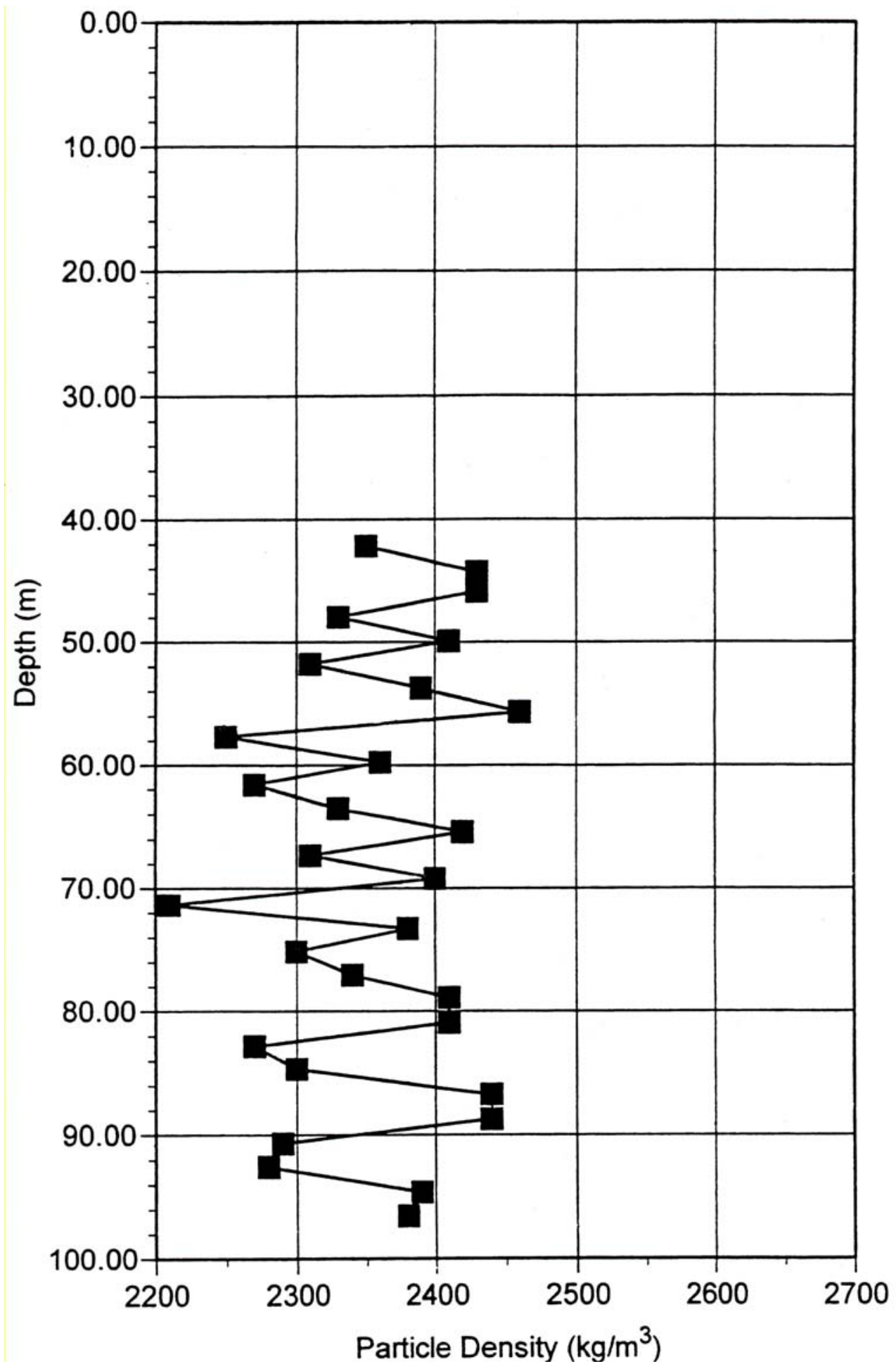

Figure C-1

Particle Density versus Depth for U-3bl-D2

(In kilograms per cubic meter) 


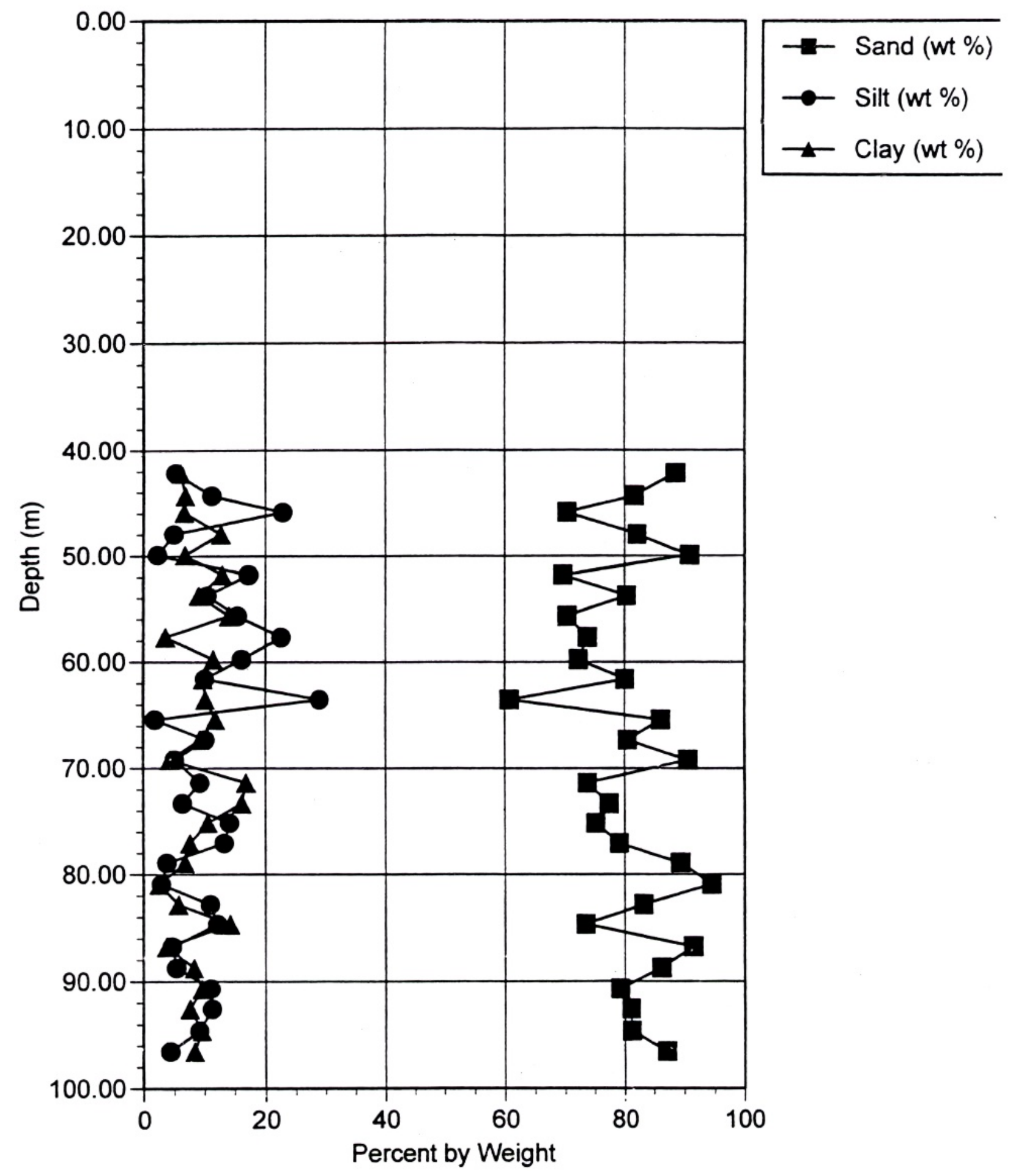

Figure C-2

Sand, Silt, and Clay Fractions versus Depth for U-3bl-D2 


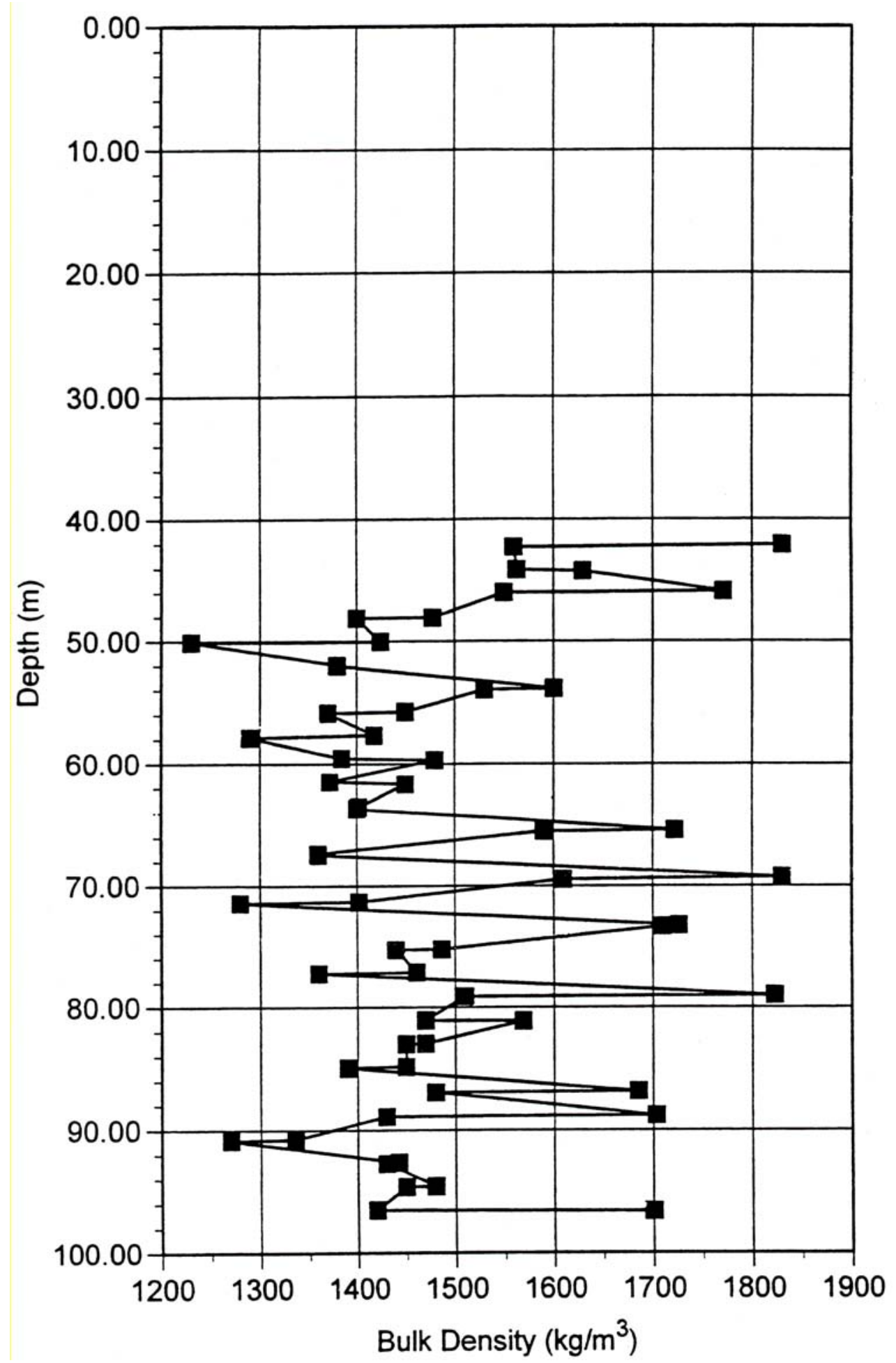

Figure C-3

Dry Bulk Density versus Depth for U-3bl-D2

(In kilograms per cubic meter) 


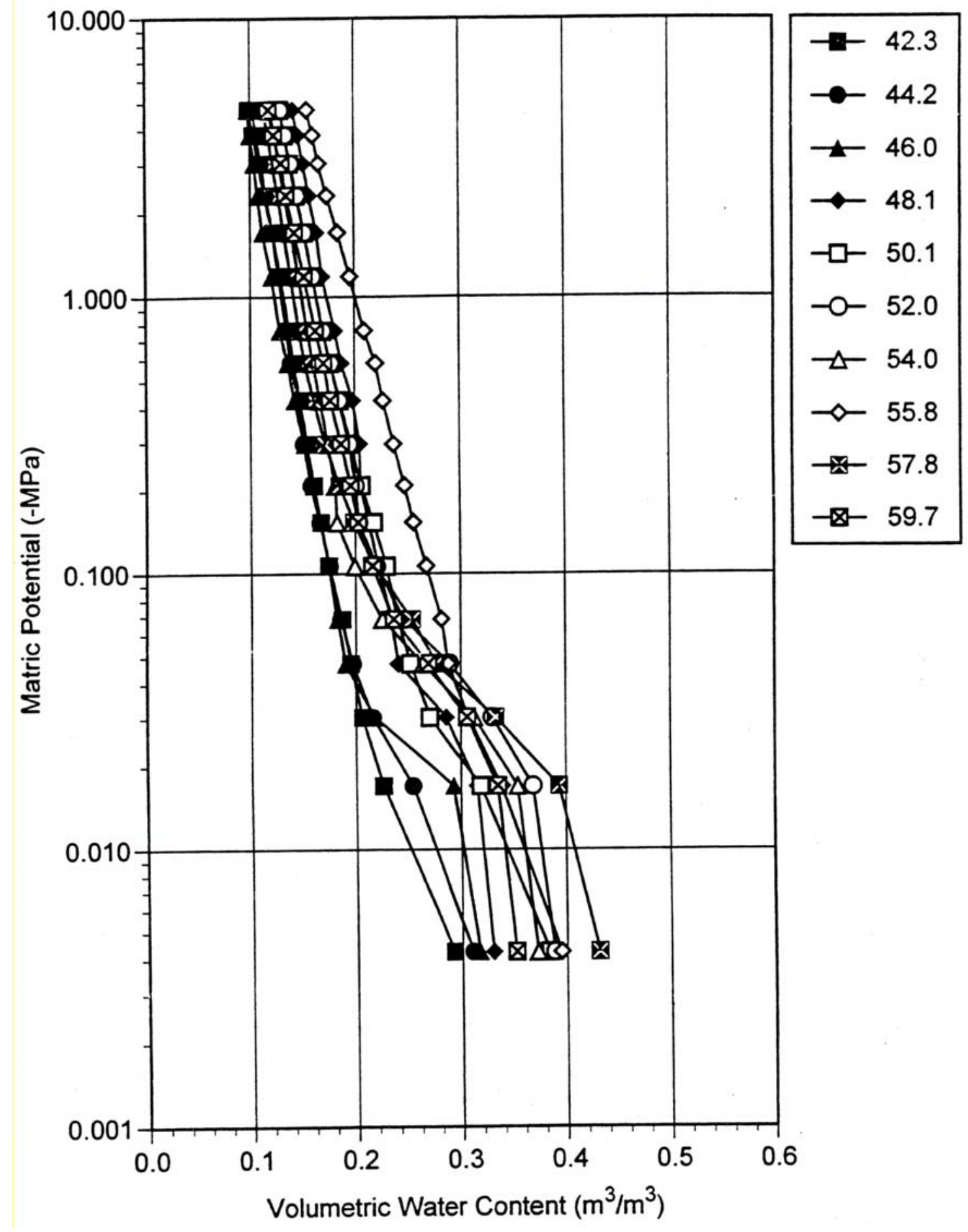

Figure C-4

Water Retention Relations for U-3bl-D2 Samples at 10 Depths from 42.3 to 59.7 Meters

(Depths indicated by symbols; matric potential in negative MegaPascals [-MPa]; water content in cubic meters per cubic meter) 


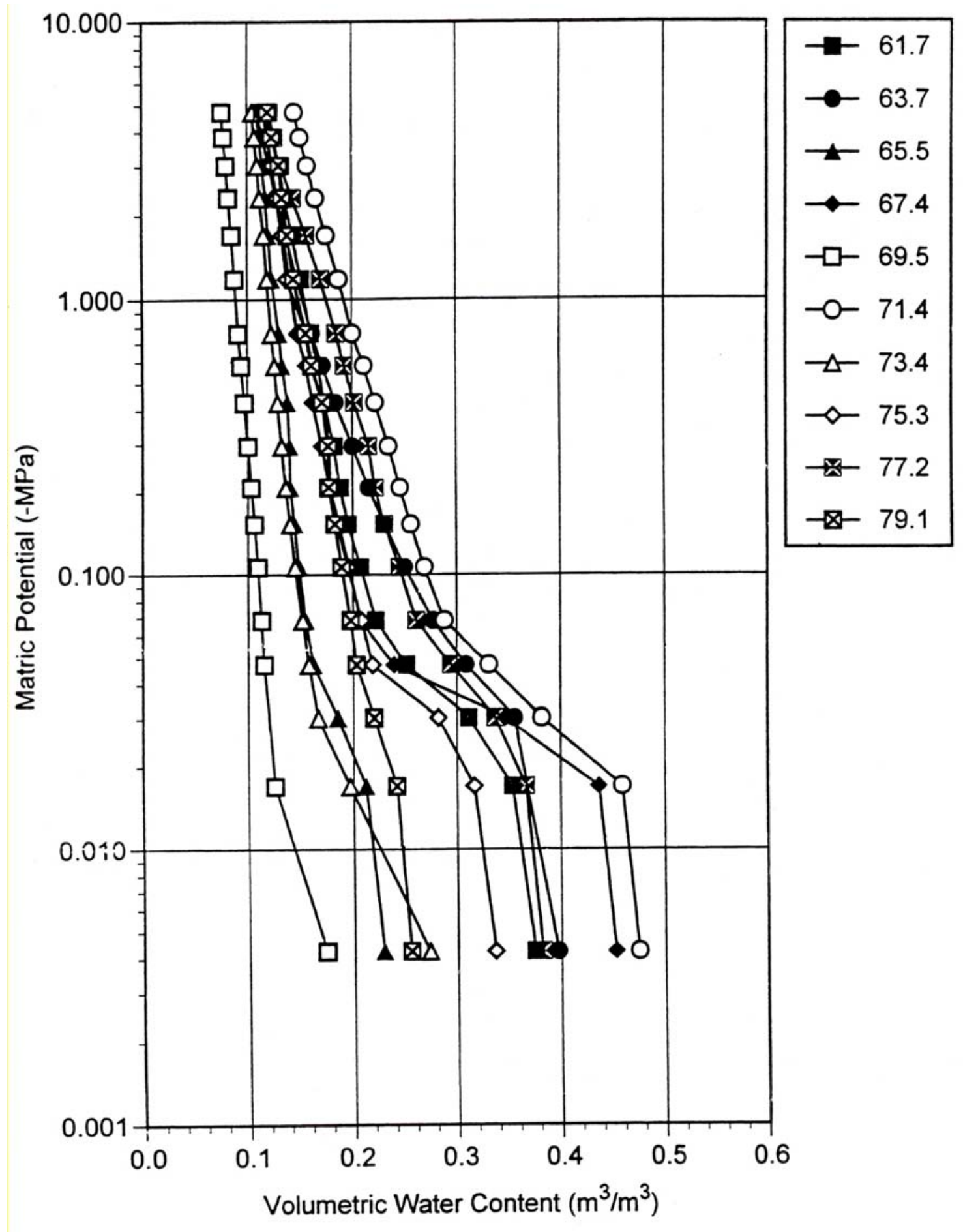

Figure C-5

Water Retention Relations for U-3bl-D2 Samples at 10 Depths from 61.7 to 79.1 Meters

(Depths indicated by symbols; matric potential in negative MegaPascals [-MPa]; water content in cubic meters per cubic meter) 


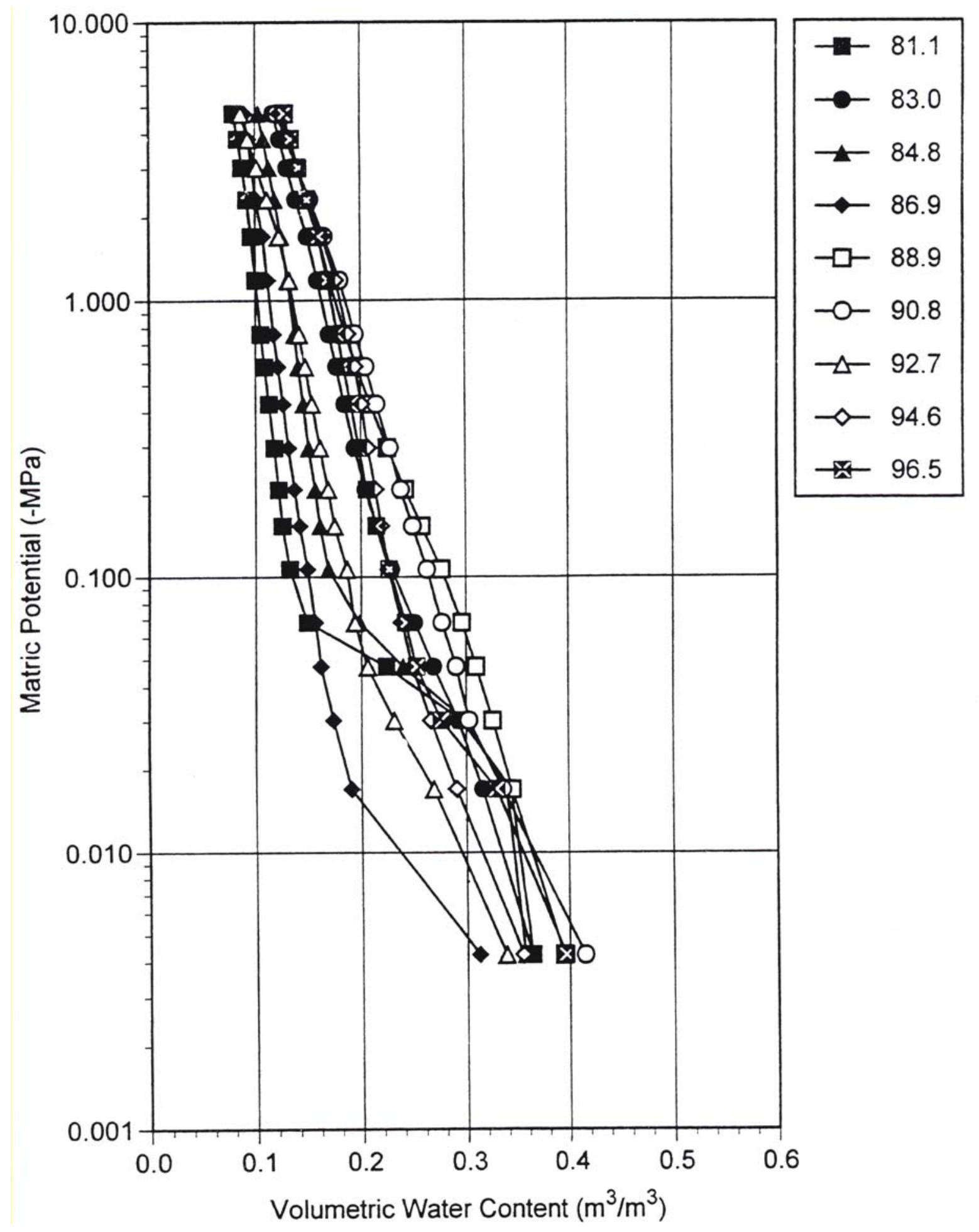

Figure C-6

Water Retention Relations for U-3bl-D2 Samples at 9 Depths from 81.1 to 96.5 Meters

(Depths indicated by symbols; matric potential in negative MegaPascals [-MPa]; water content in cubic meters per cubic meter) 


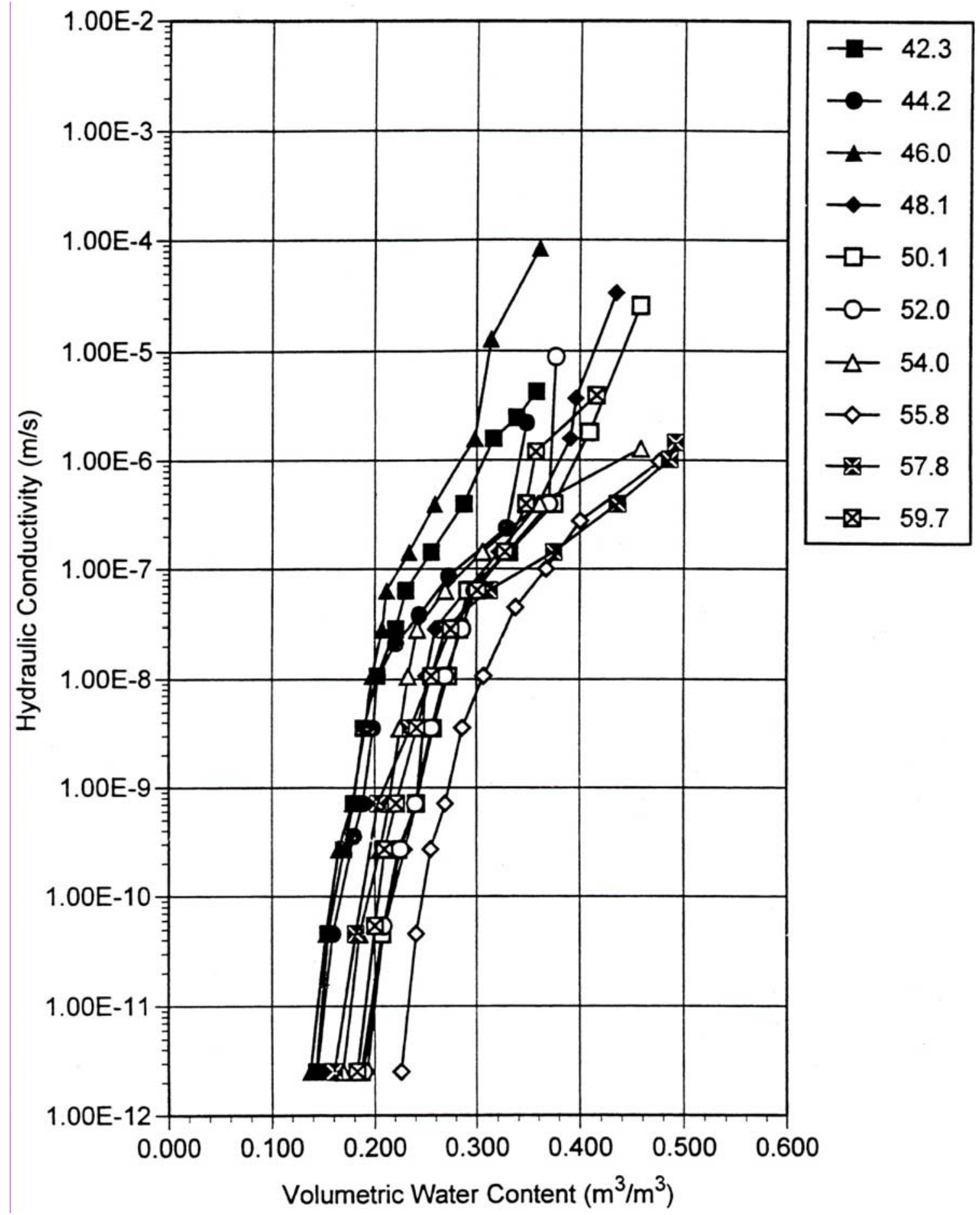

Figure C-7

Hydraulic Conductivity versus Volumetric Water Content for U-3bl-D2 Samples at 10 Depths from $\mathbf{4 2 . 3}$ to 59.7 Meters

(Depths as indicated by symbols; hydraulic conductivity in meters per second; water content in cubic meters per cubic meter) 


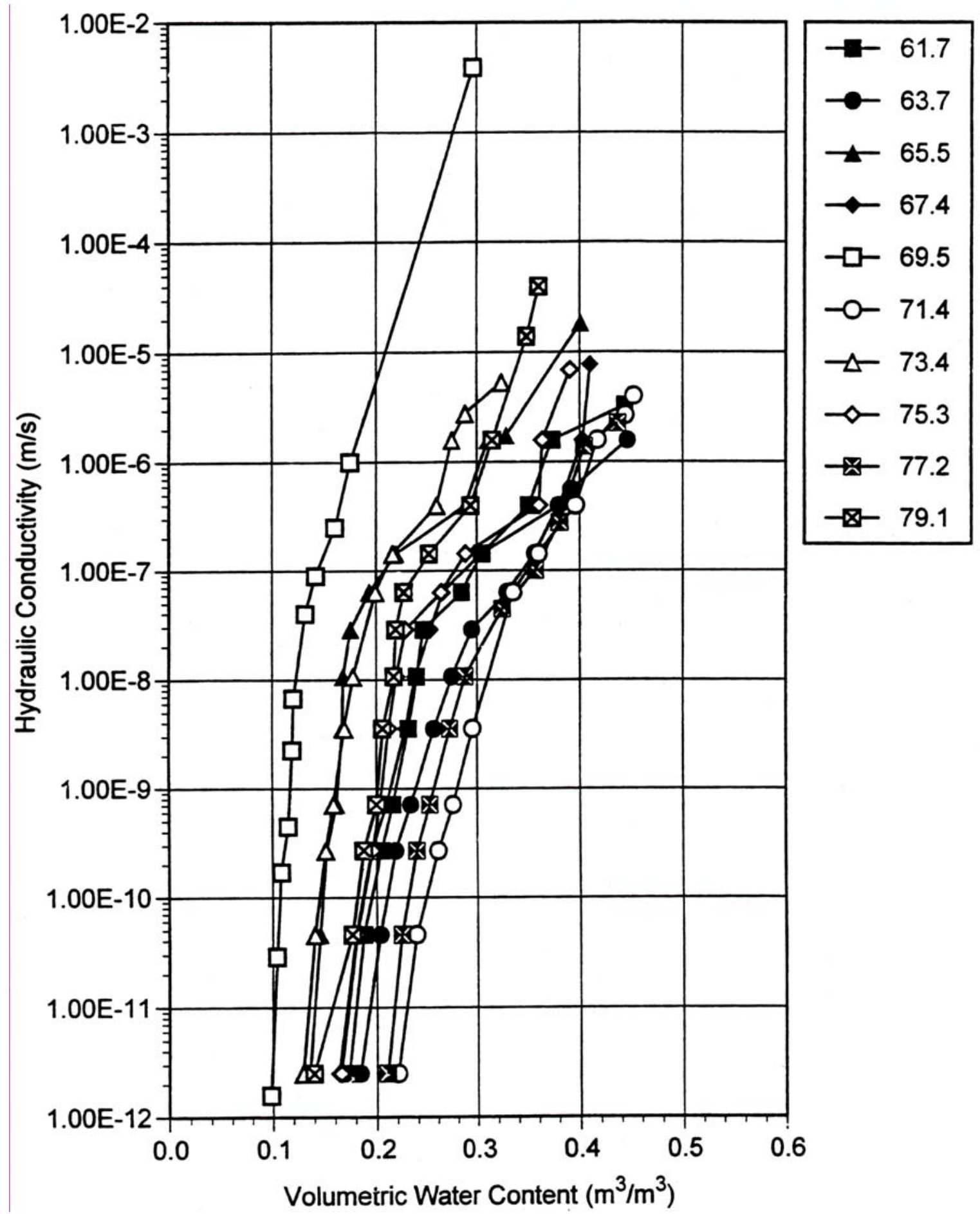

Figure C-8

Hydraulic Conductivity versus Volumetric Water Content for U-3bI-D2 Samples at 10 Depths from 61.7 to 79.1 Meters

(Depths as indicated by symbols; hydraulic conductivity in meters per second; water content in cubic meters per cubic meter) 


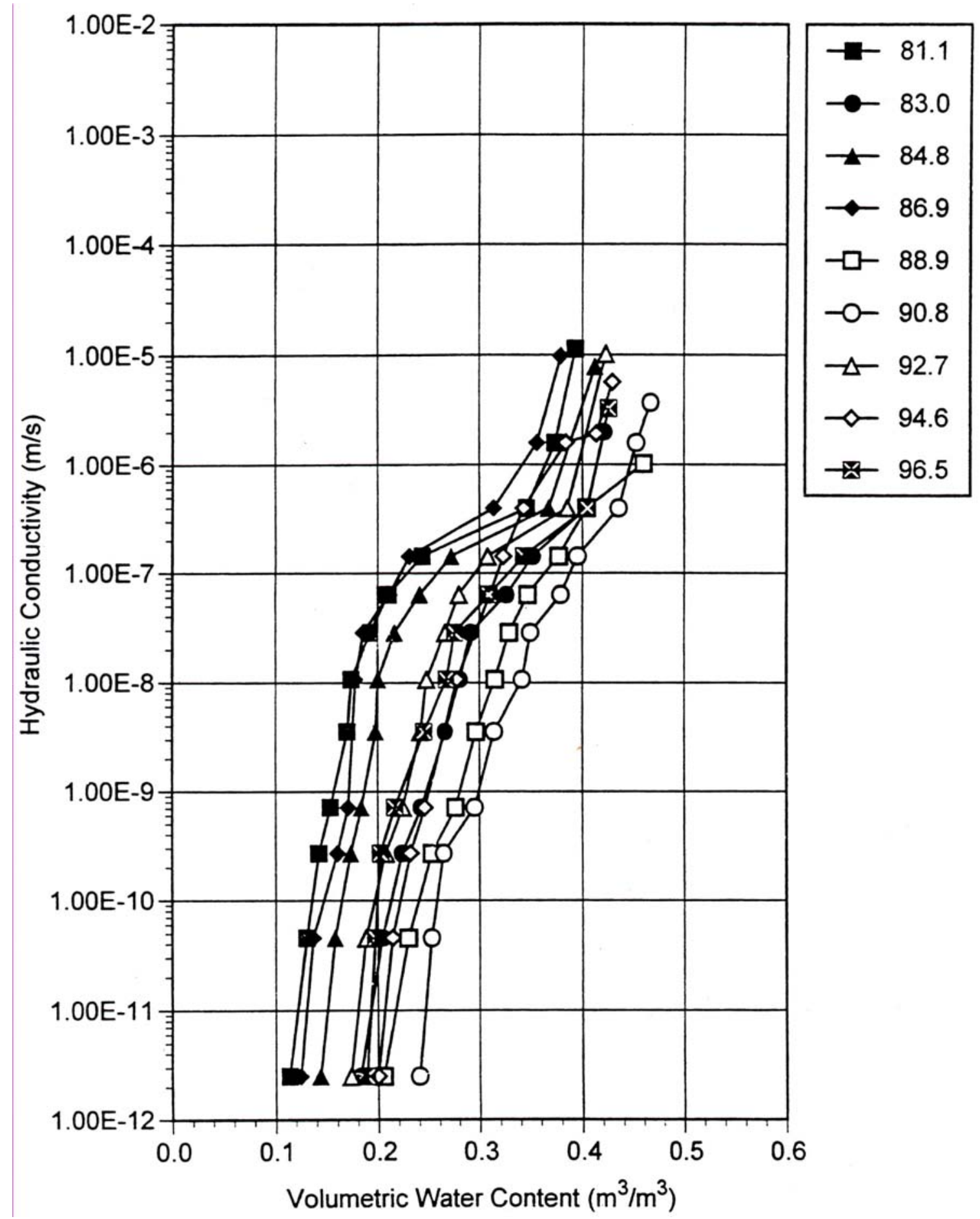

Figure C-9

Hydraulic Conductivity versus Volumetric Water Content for U-3bI-D2 Samples at 9 Depths from 81.1 to 96.5 Meters

(Depths as indicated by symbols; hydraulic conductivity in meters per second; water content in cubic meters per cubic meter) 


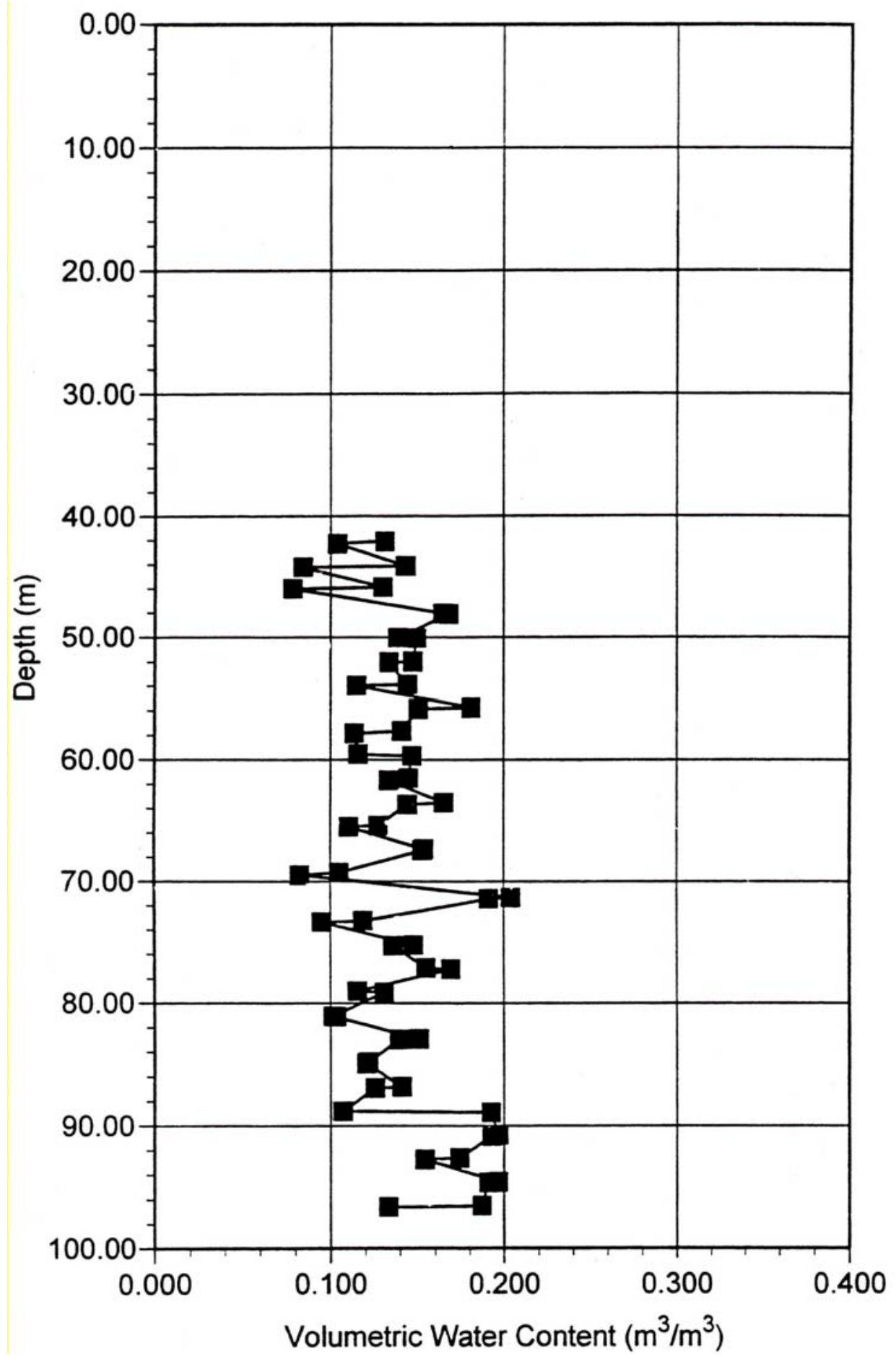

Figure C-10

Volumetric Water Content versus Depth for U-3bl-D2

(Water content in cubic meters per cubic meter) 


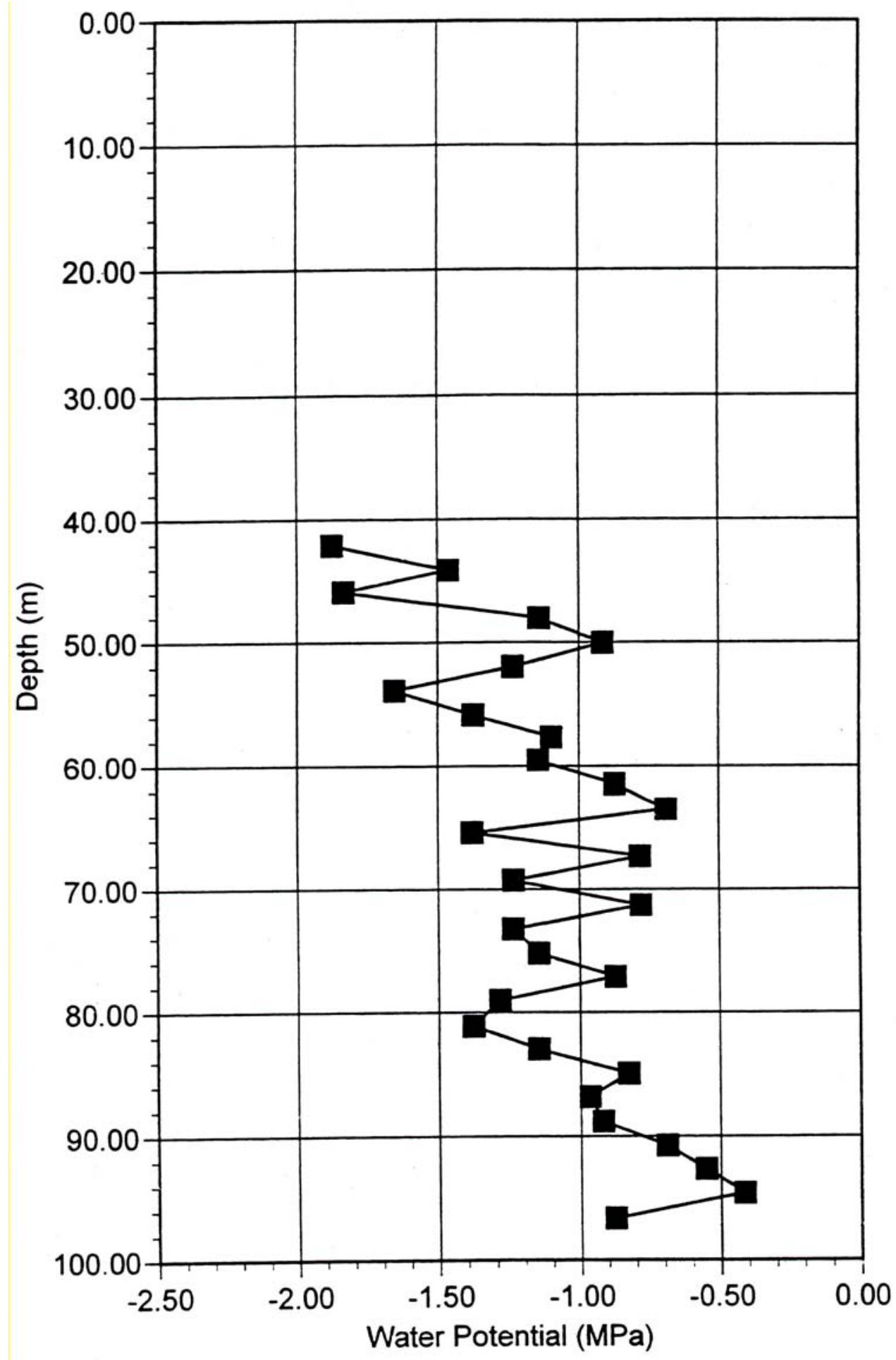

Figure C-11

Water Potential versus Depth for U-3bI-D2

(Water in MegaPascals) 


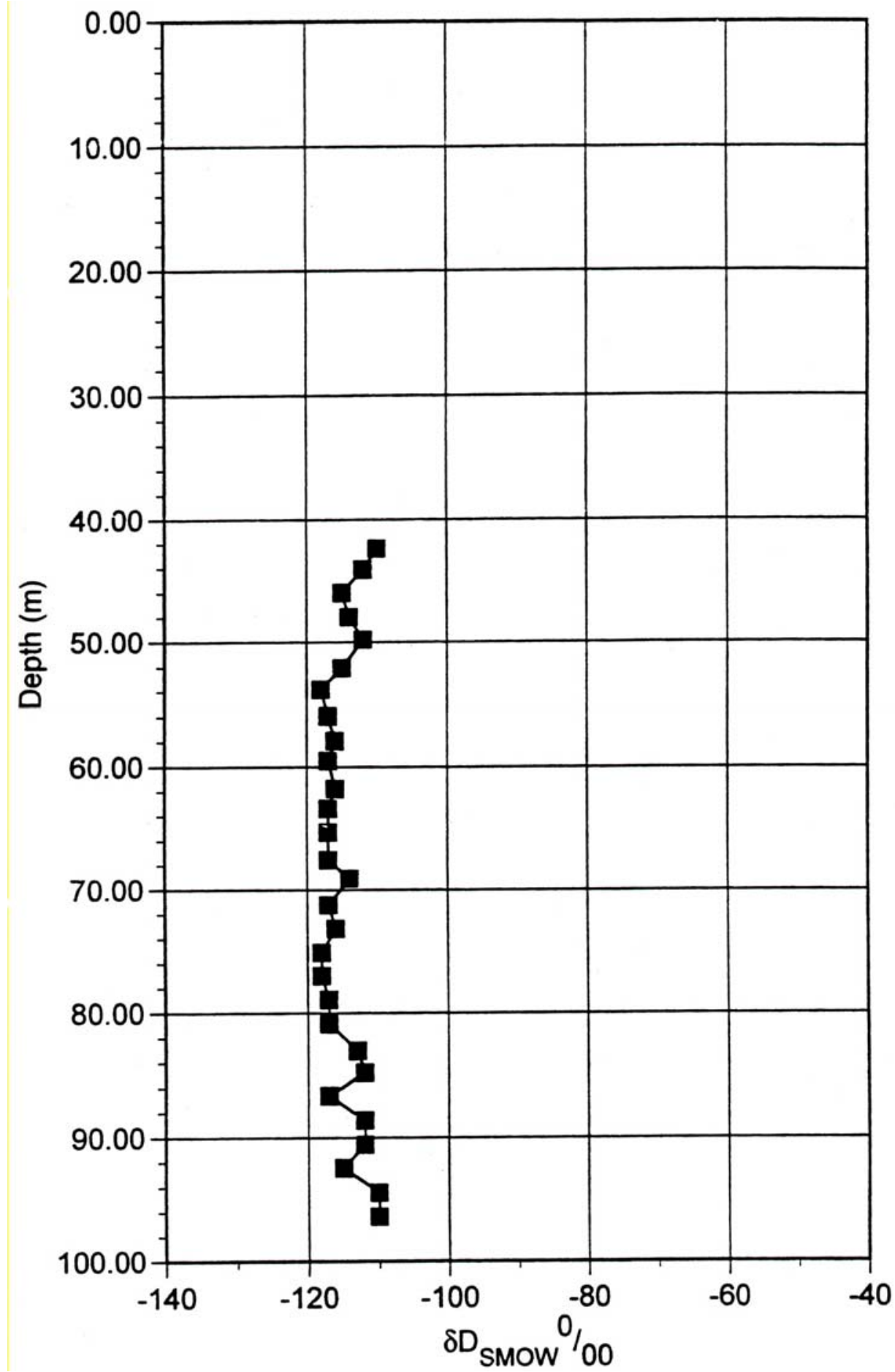

Figure C-12

Stable Hydrogen Isotope Concentration in Pore Water from U-3bl-D2 versus Depth

(Expressed in standard delta notation relative to standard mean ocean water in parts per thousand) 


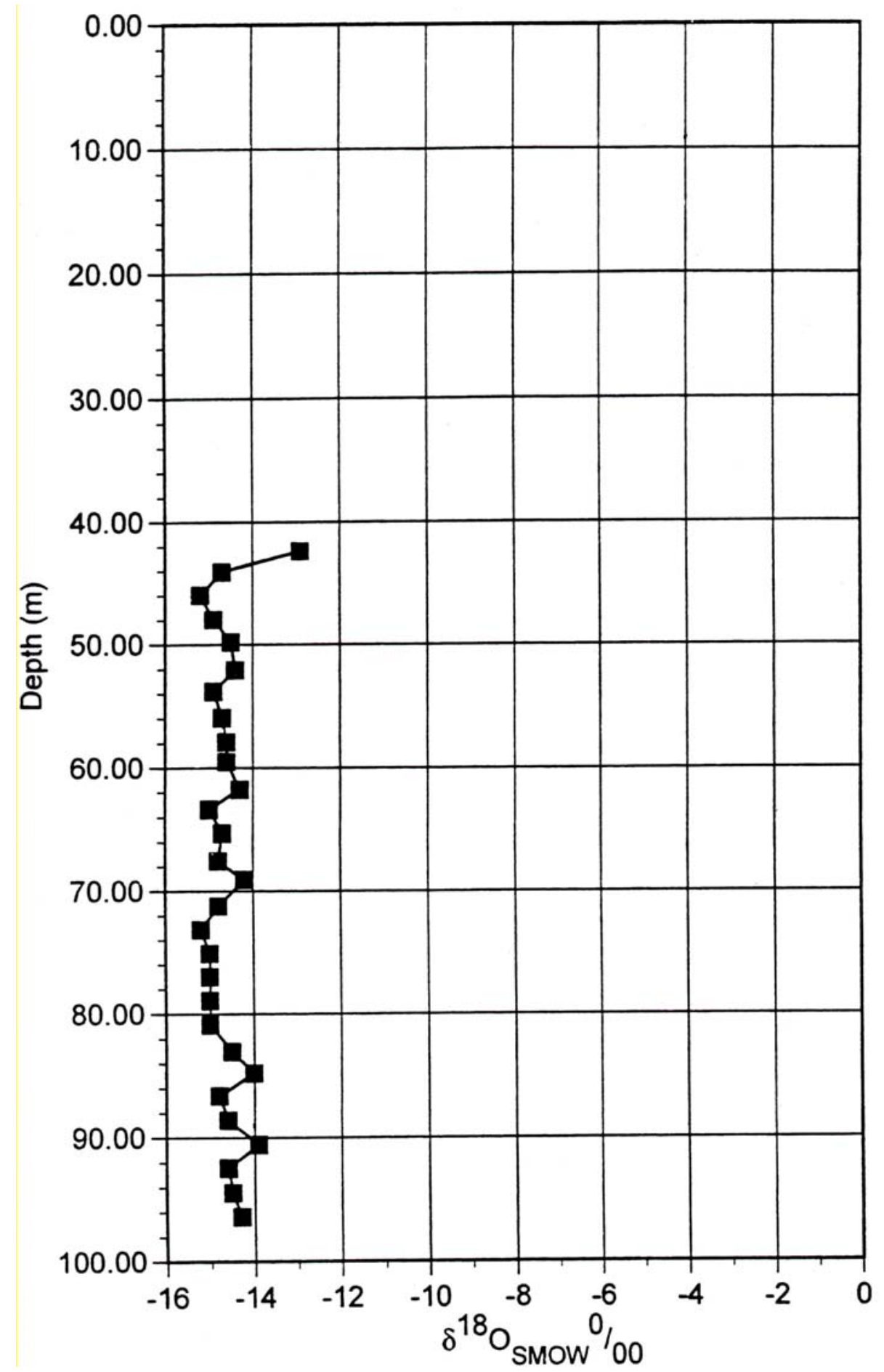

Figure C-13

Stable Oxygen Isotope Concentration in Pore Water from U-3bl-D2 versus Depth

(Expressed in standard delta notation relative to standard mean ocean water in parts per thousand) 


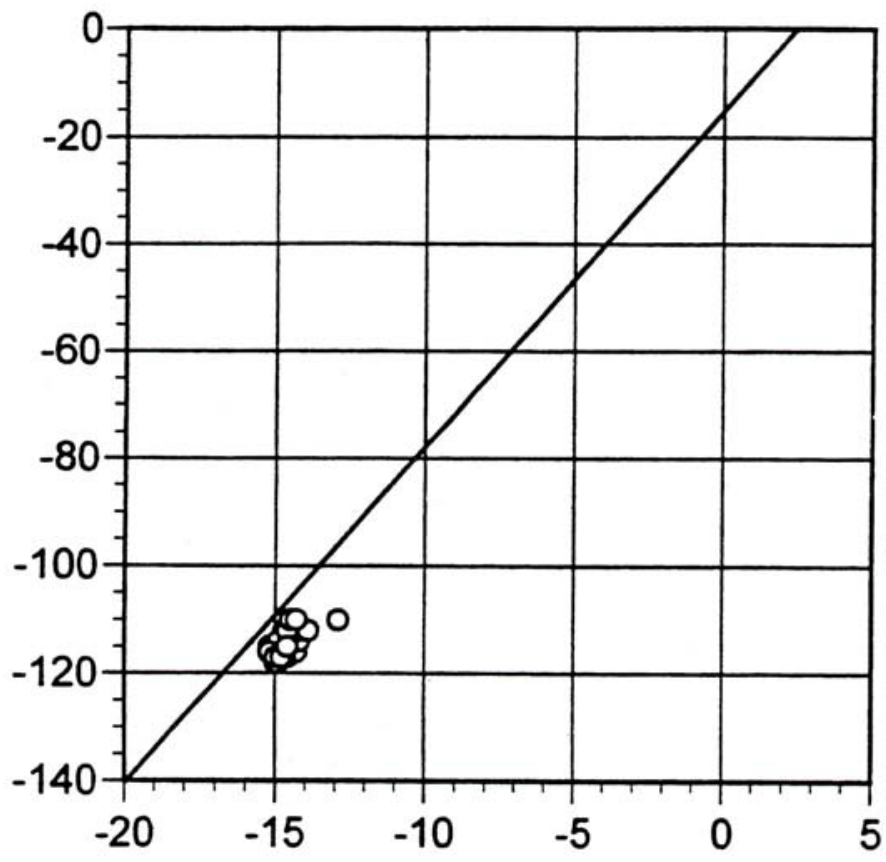

○ U-3bi-D2

LMWL

$\delta^{18} \mathrm{O}_{\text {SMOW }}{ }^{0} / 00$

Figure C-14

Stable Isotope Concentration in Pore Water from U-3bl-D2 Alluvium Samples with respect to Local Meteoric Water Line

(Expressed in standard delta notation relative to standard mean ocean water in parts per thousand) 


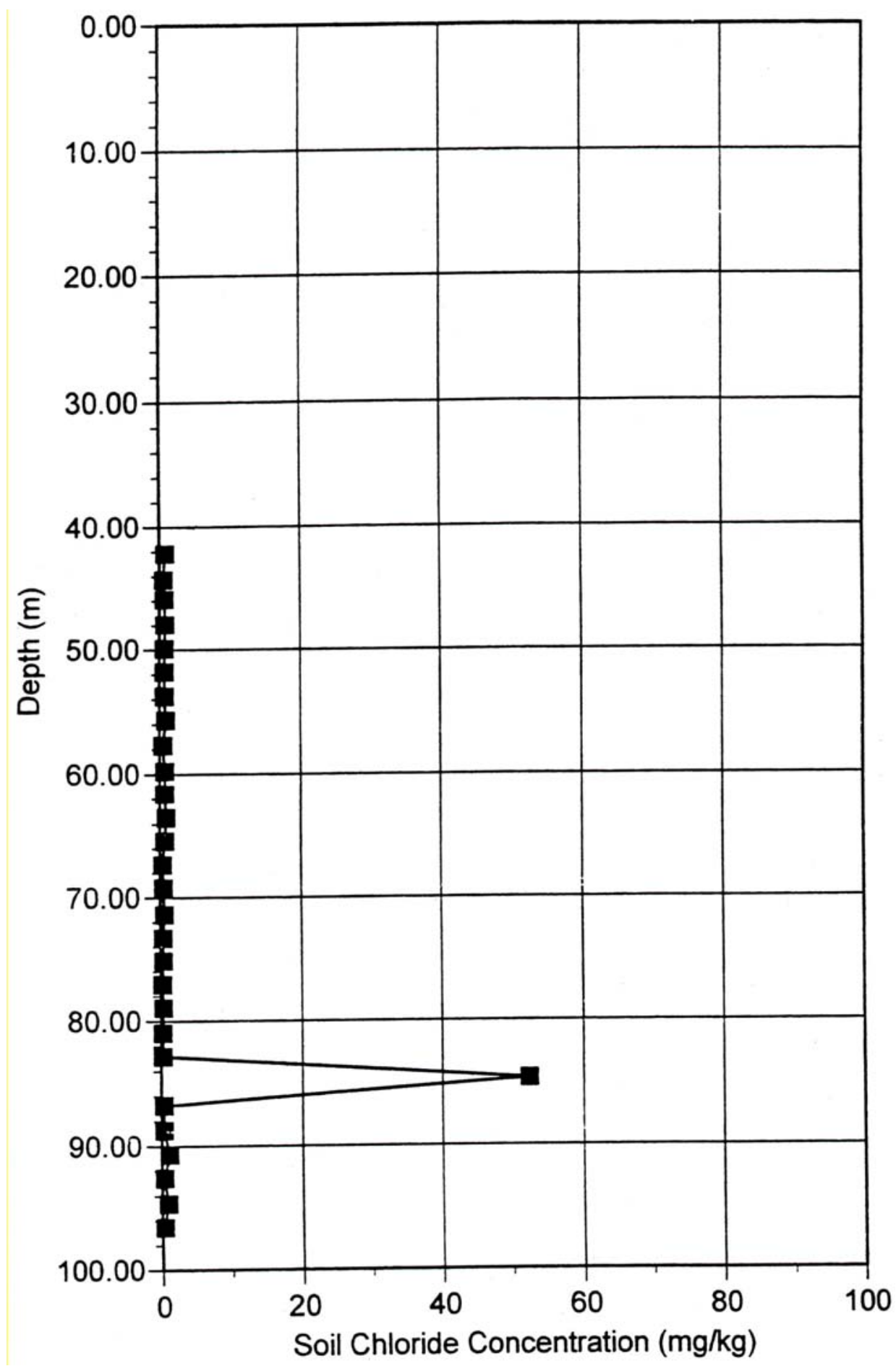

Figure C-15

Soil Chloride Concentration versus Depth for U-3bl-D2

(In milligrams per kilogram) 


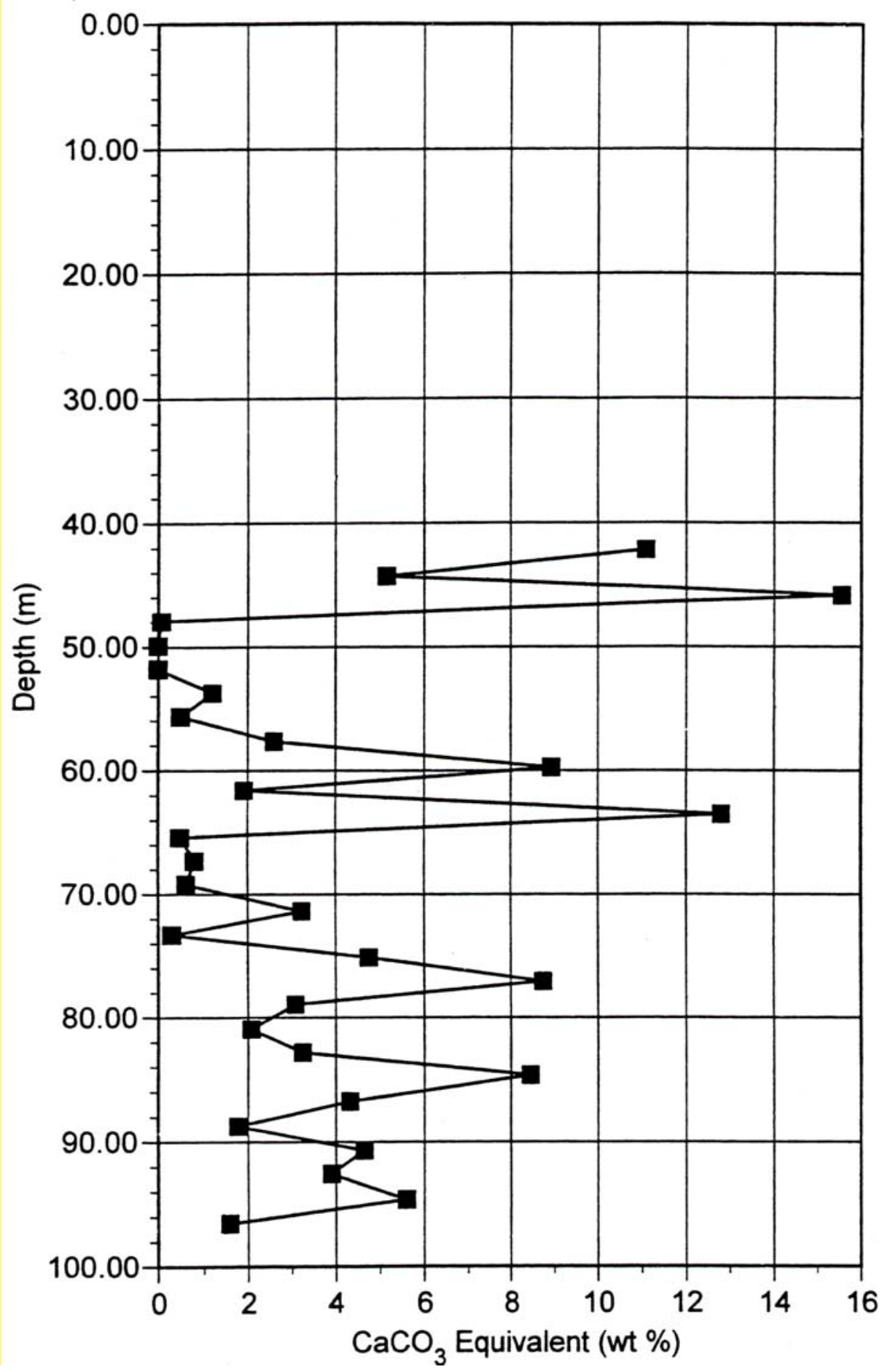

Figure C-16

Calcium Carbonate Equivalent within the Fine-Earth Fraction (less than 2 millimeters) versus Depth for U-3bl-D2

(Oven-dry weight percent) 


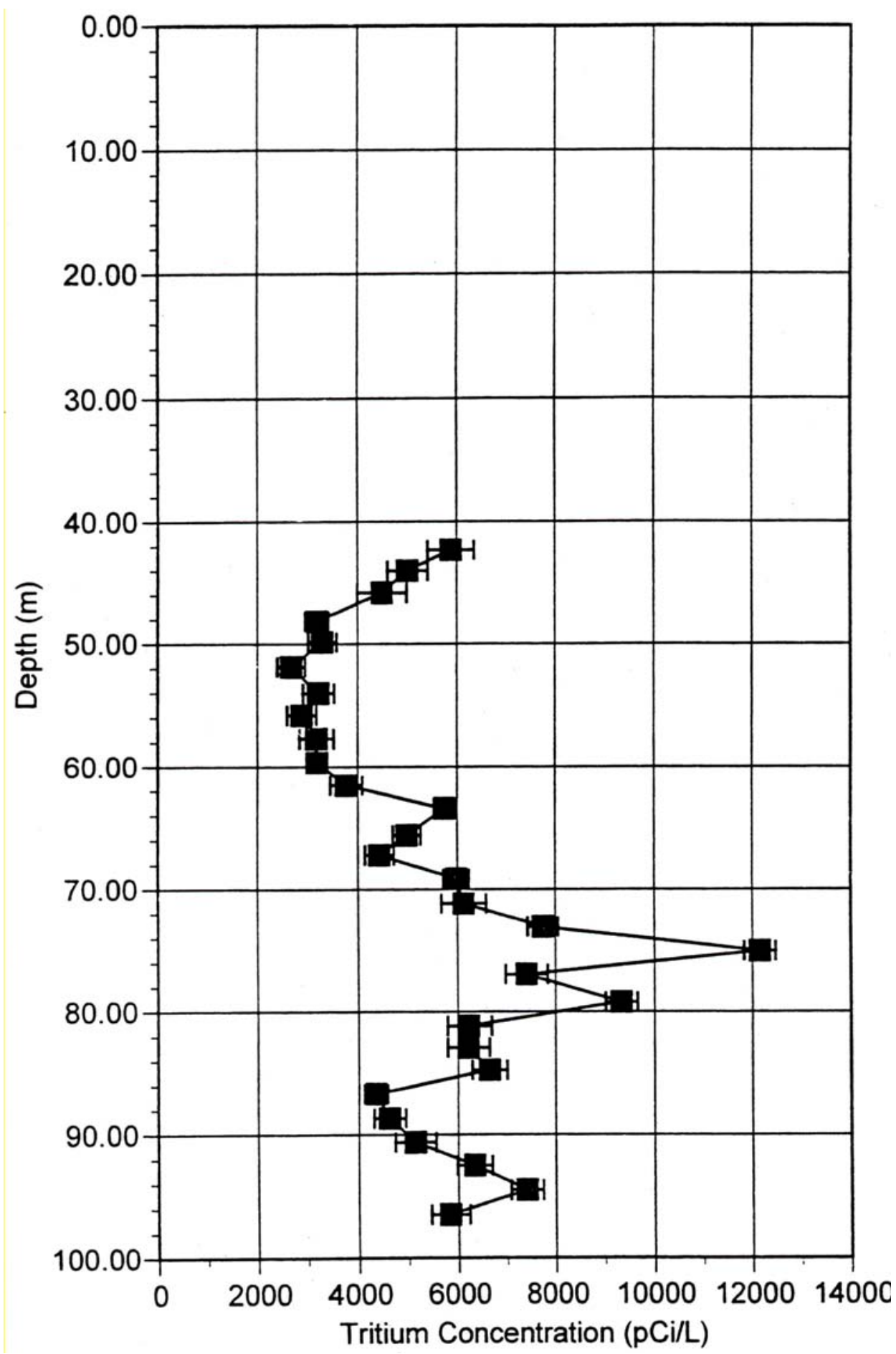

Figure C-17

Tritium Concentration versus Depth for U-3bl-D2

(In picoCuries per liter; bars indicate counting error) 
This page intentionally left blank.

C-18 
ATTACHMENT D

CHARACTERIZATION DATA TABLES FOR

BOREHOLE U-3bl-D2 
Table D-1. Particle density for U-3bl-D2 characterization samples

\begin{tabular}{|c|c|}
\hline Location: U-3bl-D2 & Analysis: Particle Density \\
\hline 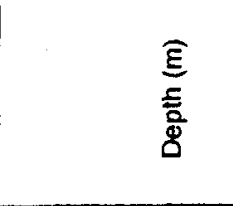 & 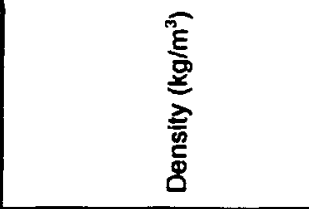 \\
\hline 42.17 & 2350 \\
\hline 44.30 & 2430 \\
\hline 45.88 & 2430 \\
\hline 47.96 & 2330 \\
\hline 49.92 & 2410 \\
\hline 51.79 & 2310 \\
\hline 53.75 & 2390 \\
\hline 55.69 & 2460 \\
\hline 57.68 & 2250 \\
\hline 59.76 & 2360 \\
\hline 61.60 & 2270 \\
\hline 63.52 & 2330 \\
\hline 65.41 & 2420 \\
\hline 67.32 & 2310 \\
\hline 69.21 & 2400 \\
\hline 71.37 & 2210 \\
\hline 73.31 & 2380 \\
\hline 75.15 & 2300 \\
\hline 77.06 & 2340 \\
\hline 78.93 & 2410 \\
\hline 80.94 & 2410 \\
\hline 82.83 & 2270 \\
\hline 84.67 & 2300 \\
\hline 86.75 & 2440 \\
\hline 88.74 & 2440 \\
\hline 90.68 & 2290 \\
\hline 92.57 & 2280 \\
\hline 94.63 & 2390 \\
\hline 96.54 & 2380 \\
\hline
\end{tabular}


Table D-2. Particle size distribution for the fine-earth $(<2 \mathrm{~mm})$ fraction for U-3bl-D2 characterization samples

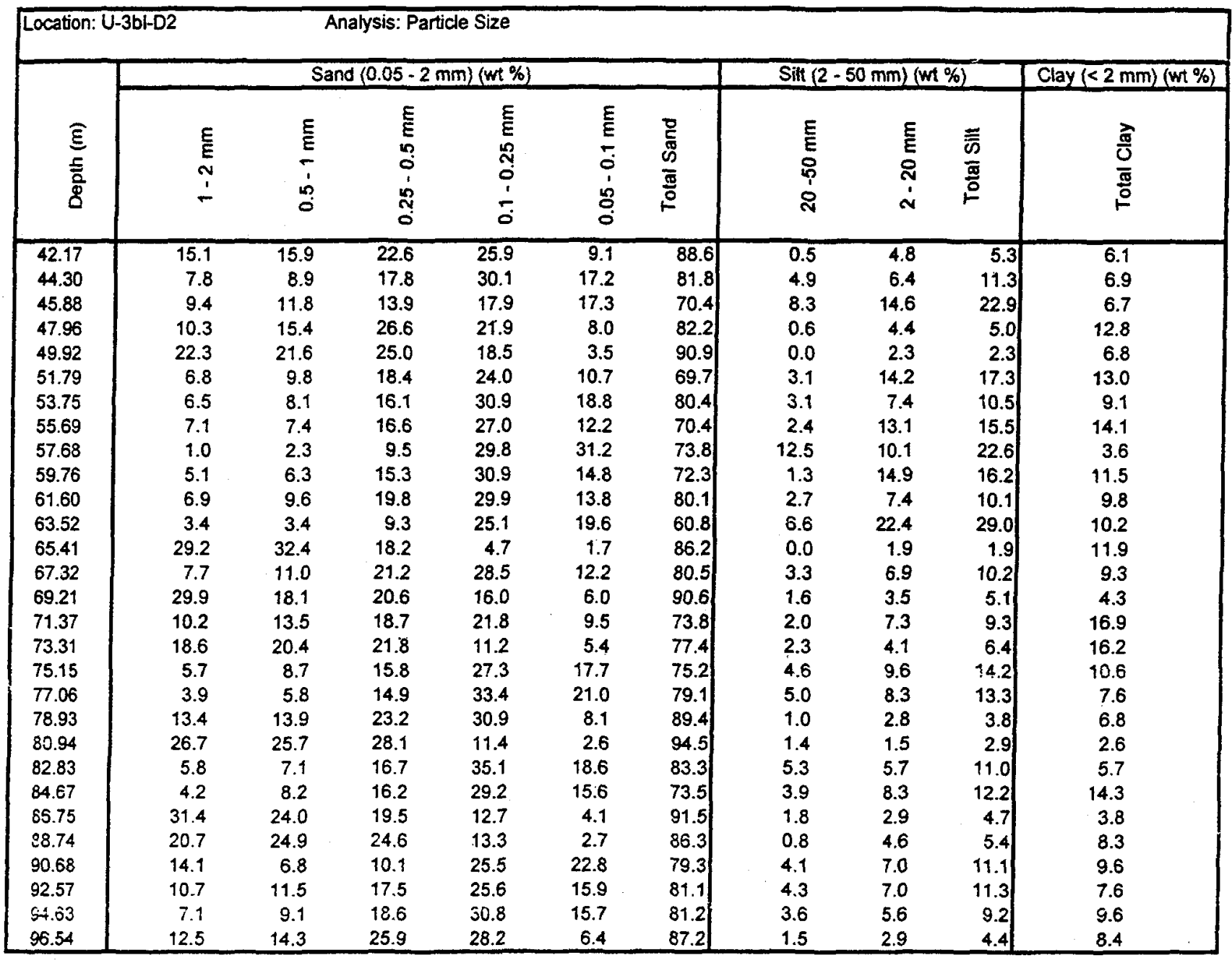


Table D-3. Bulk density for U-3bl-D2 characterization samples

\begin{tabular}{|c|c|c|c|}
\hline Location: U-3bl-D2 & \multicolumn{2}{|c|}{ Analysis: Dry Bulk Density } & \multirow[b]{2}{*}{ 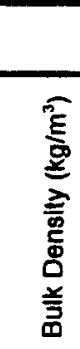 } \\
\hline $\begin{array}{l}\widehat{\underline{E}} \\
\text { 言 } \\
\text { g }\end{array}$ & 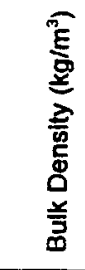 & $\begin{array}{l}\widehat{\underline{E}} \\
\text { 总 } \\
\text { g }\end{array}$ & \\
\hline 42.10 & 1830 & 69.48 & 1610 \\
\hline 42.29 & 1560 & 71.32 & 1402 \\
\hline 44.13 & 1563 & 71.42 & 1280 \\
\hline 44.23 & 1630 & 73.26 & 1726 \\
\hline 45.90 & 1772 & 73.35 & 1710 \\
\hline 46.02 & 1550 & 75.24 & 1486 \\
\hline 48.06 & 1478 & 75.29 & 1440 \\
\hline 48.10 & 1400 & 77.13 & 1461 \\
\hline 50.04 & 1425 & 77.23 & 1360 \\
\hline 50.09 & 1230 & 79.02 & 1822 \\
\hline 51.98 & 1379 & 79.12 & 1510 \\
\hline 52.03 & 1380 & 81.06 & 1470 \\
\hline 53.87 & 1600 & 81.11 & 1569 \\
\hline 53.97 & 1530 & 82.95 & 1470 \\
\hline 55.76 & 1450 & 83.00 & 1450 \\
\hline 55.86 & 1370 & 84.84 & 1450 \\
\hline 57.65 & 1418 & 84.94 & 1390 \\
\hline 57.85 & 1290 & 86.83 & 1686 \\
\hline 59.54 & 1384 & 86.92 & 1480 \\
\hline 59.69 & 1480 & 88.81 & 1703 \\
\hline 61.48 & 1372 & 88.91 & 1430 \\
\hline 61.67 & 1450 & 90.75 & 1336 \\
\hline 63.52 & 1402 & 90.85 & 1270 \\
\hline 63.66 & 1400 & 92.64 & 1442 \\
\hline 65.41 & 1722 & 92.74 & 1430 \\
\hline 65.50 & 1590 & 94.58 & 1480 \\
\hline 67.34 & 1359 & 94.63 & 1450 \\
\hline 67.44 & 1360 & 96.52 & 1420 \\
\hline 69.28 & 1830 & 96.62 & 1700 \\
\hline
\end{tabular}


Table D-4. Water retention relations for U-3bl-D2 characterization samples

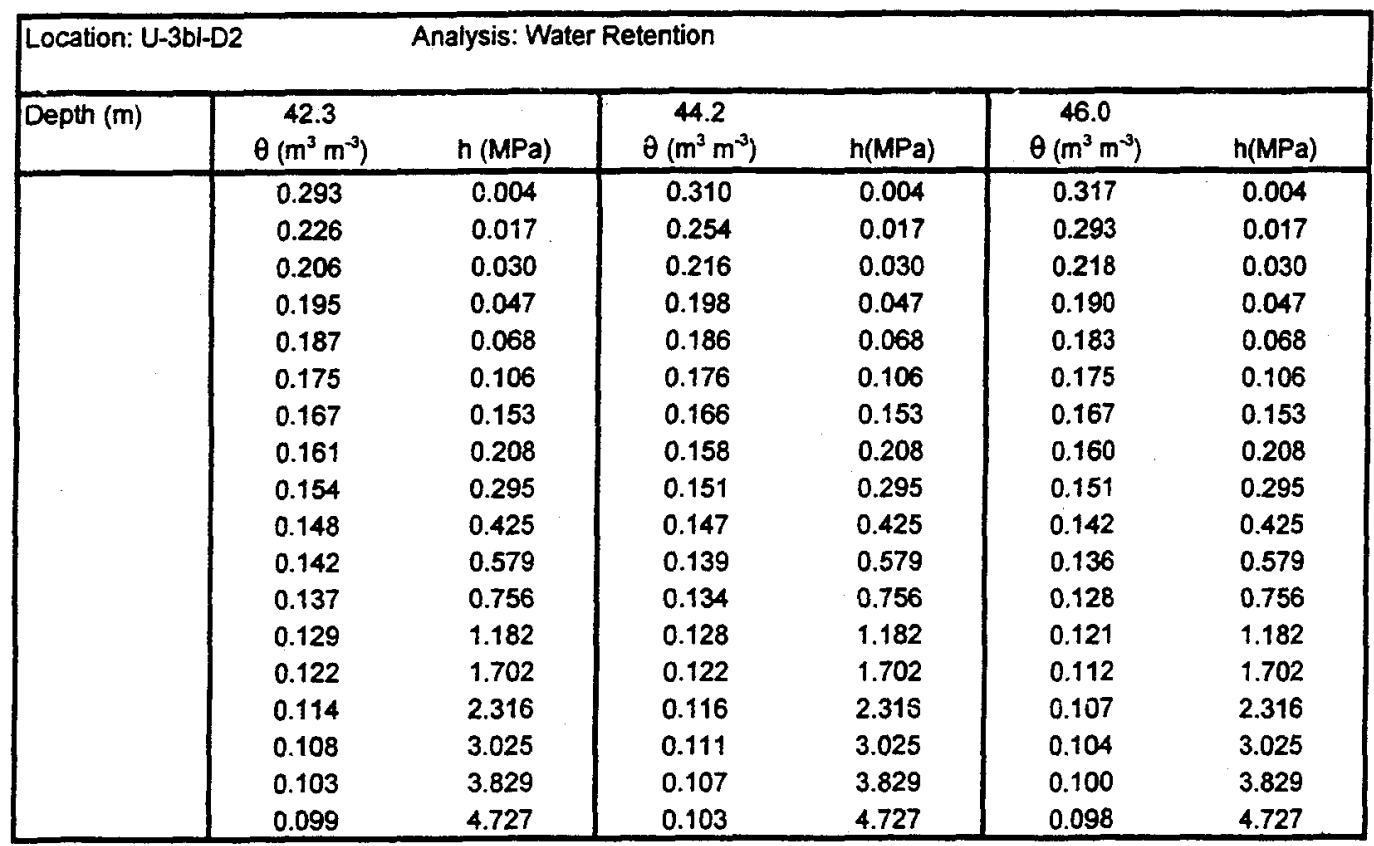

\begin{tabular}{|l|cc|cc|cc|}
\hline Location: U-3bl-D2 & \multicolumn{7}{c|}{ Analysis: Water Retention } \\
\hline Depth (m) & $\begin{array}{c}48.1 \\
\theta\left(\mathrm{m}^{3} \mathrm{~m}^{3}\right)\end{array}$ & $\mathrm{h}(\mathrm{MPa})$ & $\begin{array}{c}50.1 \\
\theta\left(\mathrm{m}^{3} \mathrm{~m}^{-3}\right)\end{array}$ & $h(\mathrm{MPa})$ & $\theta\left(\mathrm{m}^{3} \mathrm{~m}^{3}\right)$ & $\mathrm{h}(\mathrm{MPa})$ \\
\hline & 0.330 & 0.004 & 0.384 & 0.004 & 0.388 & 0.004 \\
& 0.315 & 0.017 & 0.319 & 0.017 & 0.369 & 0.017 \\
& 0.286 & 0.030 & 0.270 & 0.030 & 0.330 & 0.030 \\
& 0.240 & 0.047 & 0.252 & 0.047 & 0.290 & 0.047 \\
& 0.233 & 0.068 & 0.239 & 0.068 & 0.246 & 0.068 \\
& 0.222 & 0.106 & 0.229 & 0.106 & 0.220 & 0.106 \\
& 0.213 & 0.153 & 0.217 & 0.153 & 0.203 & 0.153 \\
& 0.206 & 0.208 & 0.206 & 0.208 & 0.201 & 0.208 \\
& 0.205 & 0.295 & 0.196 & 0.295 & 0.195 & 0.295 \\
& 0.198 & 0.425 & 0.186 & 0.425 & 0.185 & 0.425 \\
& 0.187 & 0.579 & 0.177 & 0.579 & 0.177 & 0.579 \\
& 0.181 & 0.756 & 0.170 & 0.756 & 0.170 & 0.756 \\
& 0.169 & 1.182 & 0.160 & 1.182 & 0.160 & 1.182 \\
& 0.164 & 1.702 & 0.152 & 1.702 & 0.152 & 1.702 \\
& 0.157 & 2.316 & 0.144 & 2.316 & 0.145 & 2.316 \\
& 0.151 & 3.025 & 0.138 & 3.025 & 0.139 & 3.025 \\
& 0.146 & 3.829 & 0.133 & 3.829 & 0.134 & 3.829 \\
& 0.141 & 4.727 & 0.129 & 4.727 & 0.129 & 4.727 \\
\hline
\end{tabular}


Table D-4. Water retention relations for U-3bl-D2 characterization samples (continued)

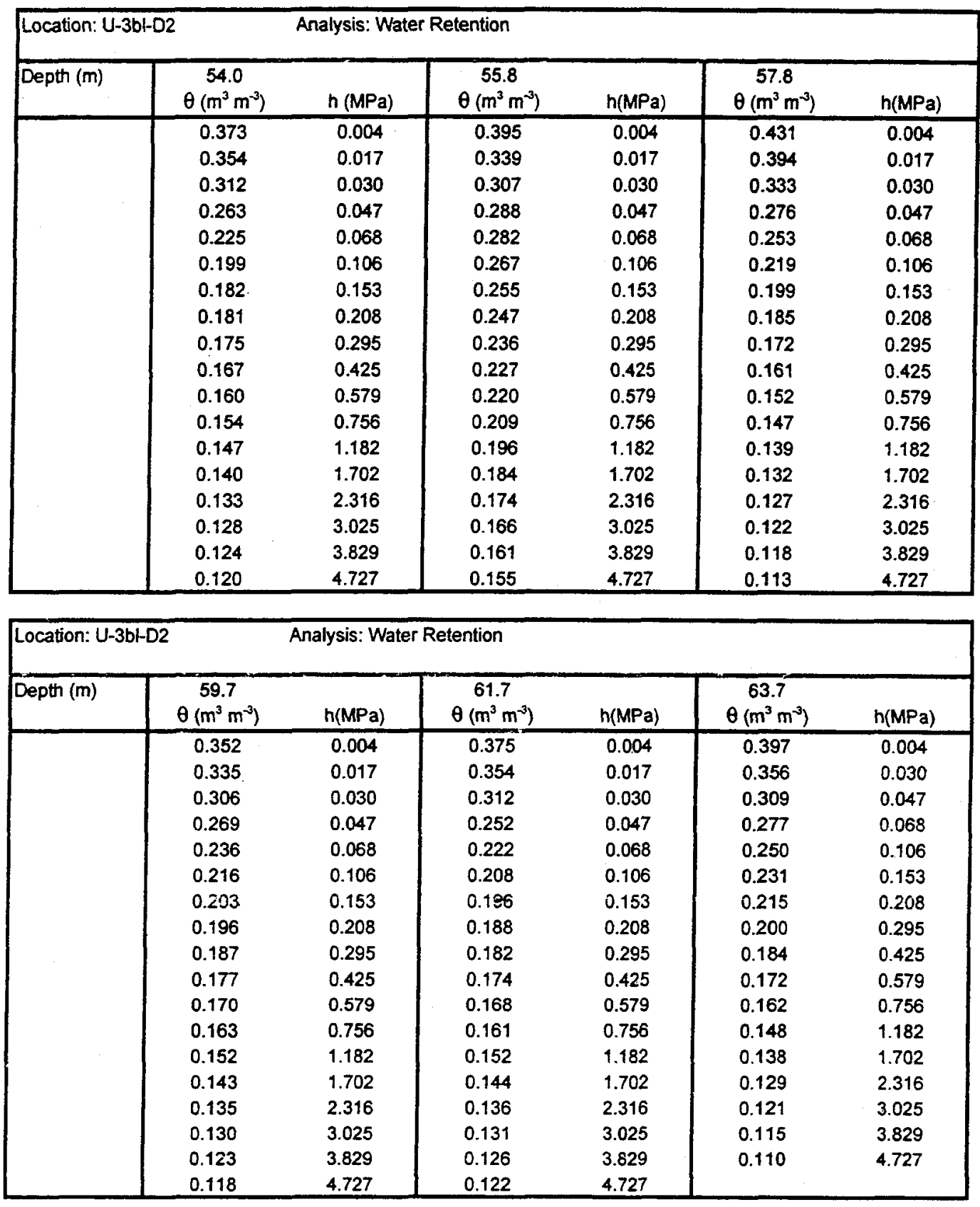


Table D-4. Water retention relations for U-3bi-D2 characterization samples (continued)

\begin{tabular}{|c|c|c|c|c|c|c|}
\hline \multicolumn{2}{|c|}{ Location: U-3bl-D2 } & \multicolumn{5}{|c|}{ Analysis: Water Relention } \\
\hline Depth $(\mathrm{m})$ & $\begin{array}{c}65.5 \\
\theta\left(\mathrm{m}^{3} \mathrm{~m}^{-3}\right)\end{array}$ & $\mathrm{h}(\mathrm{MPa})$ & $\begin{array}{c}67,4 \\
\theta\left(m^{2} m^{-3}\right) \\
\end{array}$ & $h(\mathrm{MPa})$ & $\begin{array}{c}69.5 \\
\theta\left(\mathrm{m}^{3} \mathrm{~m}^{-3}\right) \\
\end{array}$ & $h(\mathrm{MPa})$ \\
\hline & 0.229 & 0.004 & 0.452 & 0.004 & 0.174 & 0.004 \\
\hline & 0.212 & 0.017 & 0.436 & 0.017 & 0.126 & 0.017 \\
\hline & 0.186 & 0.030 & 0.346 & 0.030 & 0.115 & 0.047 \\
\hline & 0.163 & 0.047 & 0.239 & 0.047 & 0.113 & 0.068 \\
\hline & 0.155 & 0.068 & 0.207 & 0.068 & 0.110 & 0.106 \\
\hline & 0.149 & 0.106 & 0.196 & 0.106 & 0.106 & 0.153 \\
\hline & 0.145 & 0.153 & 0.187 & 0.153 & 0.103 & 0.208 \\
\hline & 0.141 & 0.208 & 0.179 & 0.208 & 0.100 & 0.295 \\
\hline & 0.141 & 0.295 & 0.171 & 0.295 & 0.097 & 0.425 \\
\hline & 0.139 & 0.425 & 0.163 & 0.425 & 0.094 & 0.579 \\
\hline & 0.134 & 0.579 & 0.157 & 0.579 & 0.091 & 0.756 \\
\hline & 0.131 & 0.756 & 0.148 & 0.756 & 0.088 & 1.182 \\
\hline & 0.124 & 1.182 & 0.141 & 1.182 & 0.085 & 1.702 \\
\hline & 0.120 & 1.702 & 0.135 & 1.702 & 0.082 & 2.316 \\
\hline & 0.117 & 2.316 & 0.129 & $2.3: 6$ & 0.080 & 3.025 \\
\hline & 0.115 & 3.025 & 0.124 & 3.025 & 0.078 & 3.829 \\
\hline & 0.112 & 3.829 & 0.120 & 3.829 & 0.076 & 4.727 \\
\hline & 0.110 & 4.727 & 0.116 & 4.727 & & \\
\hline
\end{tabular}

\begin{tabular}{|l|cc|cc|cc|}
\hline Location: U-3bI-D2 & \multicolumn{7}{c|}{ Analysis: Water Retention } \\
\hline Depth (m) & $\begin{array}{c}71.4 \\
\theta\left(\mathrm{m}^{3} \mathrm{~m}^{-3}\right)\end{array}$ & $\mathrm{h}(\mathrm{MPa})$ & $\theta\left(\mathrm{m}^{3} \mathrm{~m}^{-3}\right)$ & $\mathrm{h}(\mathrm{MPa})$ & $\theta\left(\mathrm{m}^{3} \mathrm{~m}^{-3}\right)$ & $\mathrm{h}(\mathrm{MPa})$ \\
\hline & 0.475 & 0.004 & 0.273 & 0.004 & 0.337 & 0.004 \\
& 0.459 & 0.017 & 0.197 & 0.017 & 0.317 & 0.017 \\
& 0.382 & 0.030 & 0.167 & 0.030 & 0.282 & 0.030 \\
& 0.331 & 0.047 & 0.158 & 0.047 & 0.219 & 0.047 \\
& 0.288 & 0.068 & 0.152 & 0.068 & 0.208 & 0.068 \\
& 0.269 & 0.106 & 0.145 & 0.106 & 0.195 & 0.106 \\
& 0.256 & 0.153 & 0.141 & 0.153 & 0.186 & 0.153 \\
& 0.246 & 0.208 & 0.137 & 0.208 & 0.179 & 0.208 \\
& 0.235 & 0.295 & 0.133 & 0.295 & 0.178 & 0.295 \\
& 0.222 & 0.425 & 0.129 & 0.425 & 0.172 & 0.425 \\
& 0.211 & 0.579 & 0.126 & 0.579 & 0.163 & 0.579 \\
& 0.200 & 0.756 & 0.123 & 0.756 & 0.158 & 0.756 \\
& 0.187 & 1.182 & 0.119 & 1.182 & 0.138 & 1.182 \\
& 0.176 & 1.702 & 0.116 & 1.702 & 0.134 & 1.702 \\
& 0.166 & 2.316 & 0.112 & 2.316 & 0.129 & 2.316 \\
& 0.158 & 3.025 & 0.110 & 3.025 & 0.124 & 3.025 \\
& 0.151 & 3.829 & 0.107 & 3.829 & 0.120 & 3.829 \\
& 0.146 & 4.727 & 0.105 & 4.727 & 0.117 & 4.727 \\
& & & & & &
\end{tabular}


Table D-4. Water retention relations for U-3bl-D2 characterization samples (continued)

\begin{tabular}{|l|cc|cc|cc|}
\hline Location: U-3bl-D2 & \multicolumn{7}{c|}{ Analysis: Water Retention } \\
\hline Depth (m) & 77.2 & & 79.1 & 81.1 & \\
& $\theta\left(\mathrm{m}^{3} \mathrm{~m}^{-3}\right)$ & $\mathrm{h}(\mathrm{MPa})$ & $\theta\left(\mathrm{m}^{3} \mathrm{~m}^{-3}\right)$ & $\mathrm{h}(\mathrm{MPa})$ & $\theta\left(\mathrm{m}^{3} \mathrm{~m}^{-3}\right)$ & $\mathrm{h}(\mathrm{MPa})$ \\
\hline & 0.383 & 0.004 & 0.255 & 0.004 & 0.364 & 0.004 \\
& 0.367 & 0.017 & 0.242 & 0.017 & 0.344 & 0.017 \\
& 0.337 & 0.030 & 0.220 & 0.030 & 0.295 & 0.030 \\
& 0.294 & 0.047 & 0.203 & 0.047 & 0.224 & 0.047 \\
& 0.261 & 0.068 & 0.198 & 0.068 & 0.148 & 0.068 \\
& 0.245 & 0.106 & 0.189 & 0.106 & 0.132 & 0.106 \\
& 0.231 & 0.153 & 0.183 & 0.153 & 0.125 & 0.153 \\
& 0.222 & 0.208 & 0.178 & 0.208 & 0.121 & 0.208 \\
& 0.215 & 0.295 & 0.177 & 0.295 & 0.117 & 0.295 \\
& 0.202 & 0.425 & 0.172 & 0.425 & 0.112 & 0.425 \\
& 0.193 & 0.579 & 0.162 & 0.579 & 0.108 & 0.579 \\
& 0.185 & 0.756 & 0.157 & 0.756 & 0.105 & 0.756 \\
& 0.171 & 1.182 & 0.145 & 1.182 & 0.100 & 1.182 \\
& 0.157 & 1.702 & 0.139 & 1.702 & 0.096 & 1.702 \\
& 0.144 & 2.316 & 0.134 & 2.316 & 0.092 & 2.316 \\
& 0.133 & 3.025 & 0.131 & 3.025 & 0.088 & 3.025 \\
& 0.124 & 3.829 & 0.124 & 3.829 & 0.084 & 3.829 \\
& 0.115 & 4.727 & 0.120 & 4.727 & 0.080 & 4.727 \\
\hline
\end{tabular}

\begin{tabular}{|l|cc|cc|cc|}
\hline Location: U-3bl-D2 & \multicolumn{7}{c|}{ Analysis: Water Retention } \\
\hline Depth $(\mathrm{m})$ & $\begin{array}{c}83.0 \\
\theta\left(\mathrm{m}^{3} \mathrm{~m}^{-3}\right)\end{array}$ & $\mathrm{h}(\mathrm{MPa})$ & $\begin{array}{c}84.8 \\
\theta\left(\mathrm{m}^{3} \mathrm{~m}^{-3}\right)\end{array}$ & $\mathrm{h}(\mathrm{MPa})$ & $\theta\left(\mathrm{m}^{3} \mathrm{~m}^{-3}\right)$ & $\mathrm{h}(\mathrm{MPa})$ \\
\hline & 0.363 & 0.004 & 0.357 & 0.004 & 0.312 & 0.004 \\
& 0.316 & 0.017 & 0.339 & 0.017 & 0.190 & 0.017 \\
& 0.292 & 0.030 & 0.299 & 0.030 & 0.173 & 0.030 \\
& 0.269 & 0.047 & 0.240 & 0.047 & 0.161 & 0.047 \\
& 0.251 & 0.068 & 0.199 & 0.068 & 0.156 & 0.068 \\
& 0.229 & 0.106 & 0.168 & 0.106 & 0.149 & 0.106 \\
& 0.215 & 0.153 & 0.161 & 0.153 & 0.141 & 0.153 \\
& 0.204 & 0.208 & 0.156 & 0.208 & 0.136 & 0.208 \\
& 0.194 & 0.295 & 0.150 & 0.295 & 0.131 & 0.295 \\
& 0.184 & 0.425 & 0.145 & 0.425 & 0.126 & 0.425 \\
& 0.176 & 0.579 & 0.140 & 0.579 & 0.121 & 0.579 \\
& 0.170 & 0.756 & 0.137 & 0.756 & 0.117 & 0.756 \\
& 0.158 & 1.182 & 0.130 & 1.182 & 0.112 & 1.182 \\
& 0.149 & 1.702 & 0.124 & 1.702 & 0.107 & 1.702 \\
& 0.138 & 2.316 & 0.118 & 2.316 & 0.101 & 2.316 \\
& 0.130 & 3.025 & 0.113 & 3.025 & 0.097 & 3.025 \\
& 0.123 & 3.829 & 0.108 & 3.829 & 0.093 & 3.829 \\
& 0.117 & 4.727 & 0.103 & 4.727 & 0.090 & 4.727 \\
\hline
\end{tabular}


Table D-4. Water retention relations for U-3bl-D2 characterization samples (continued)

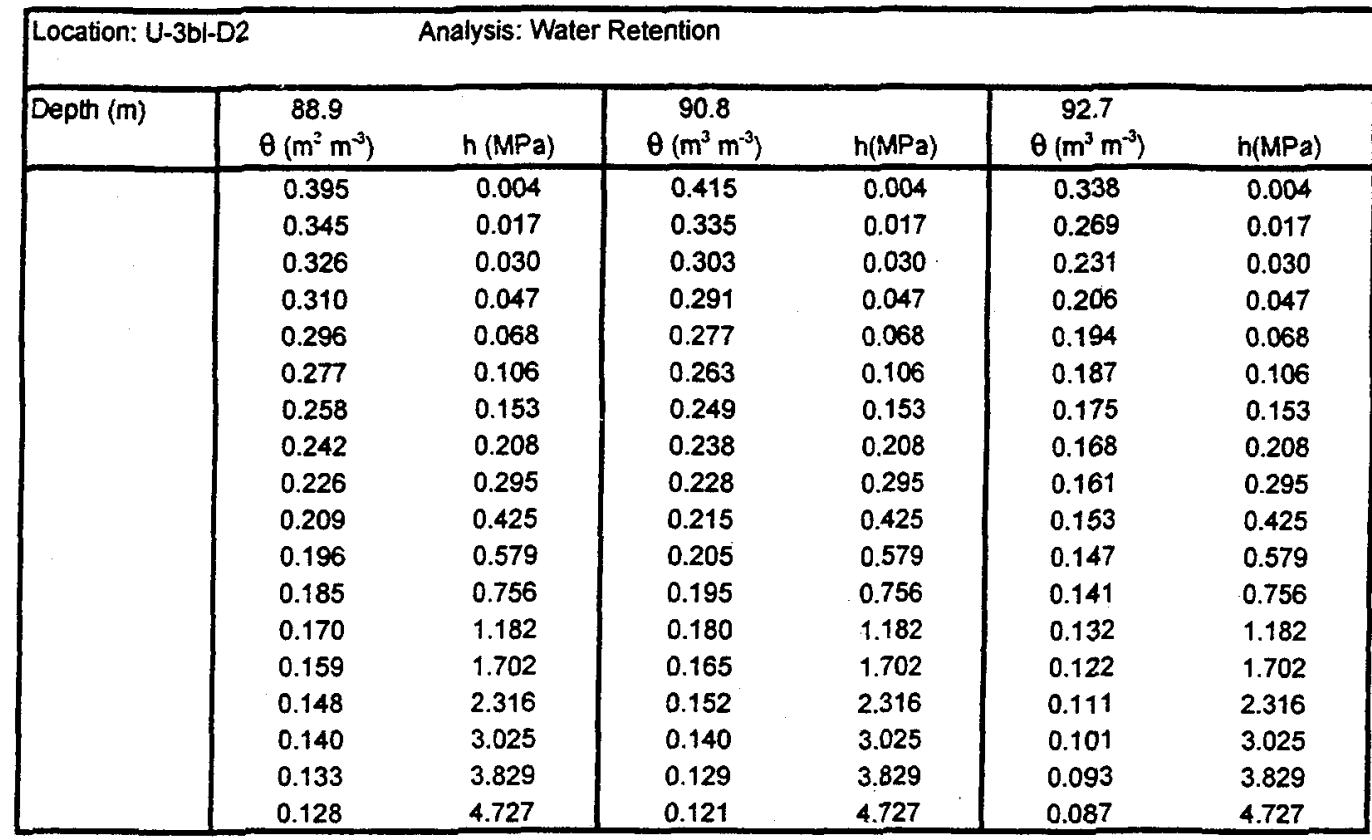

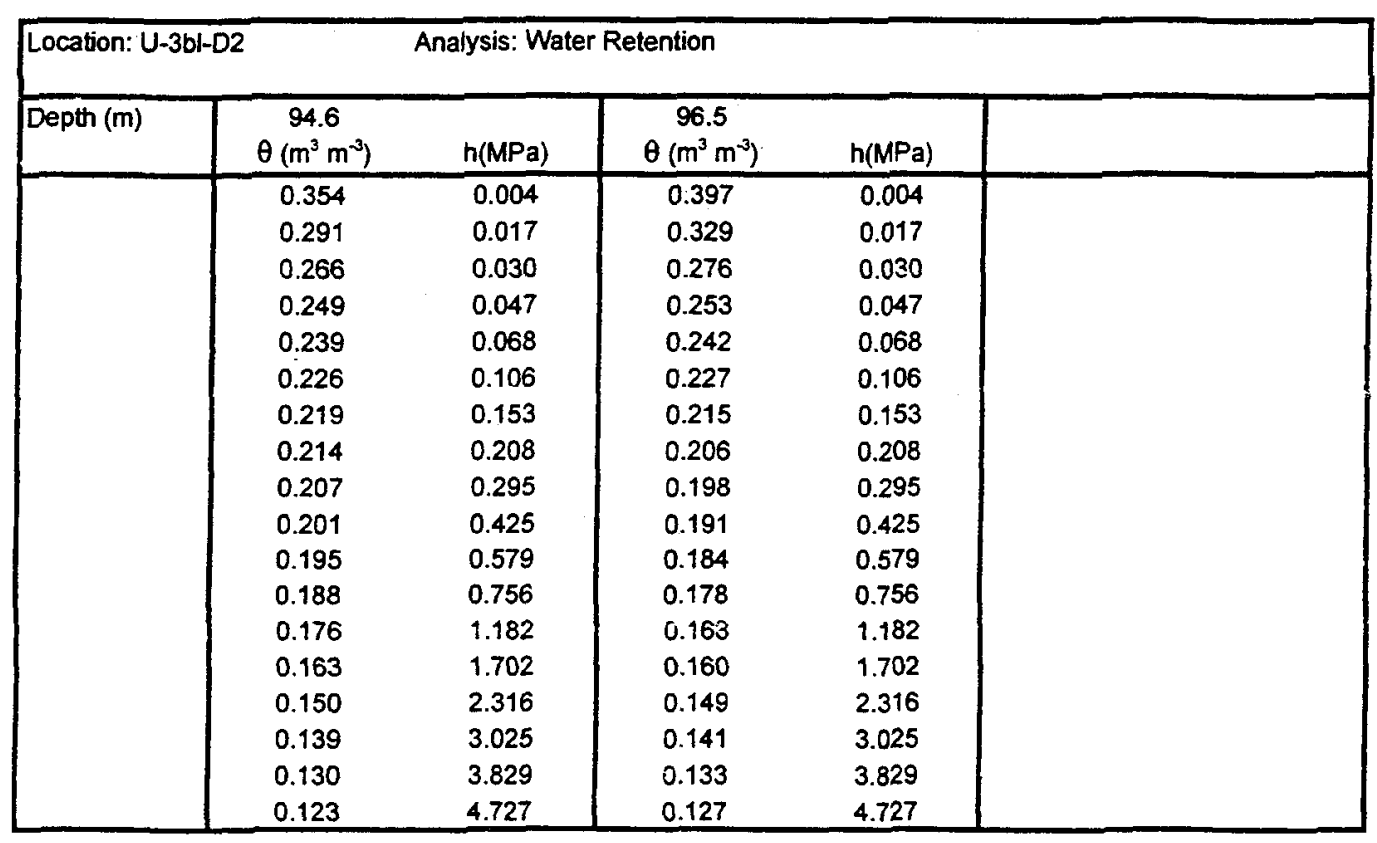


Table D-5. Hydraulic conductivity - water content relations for U-3bl-D2 characterization samples

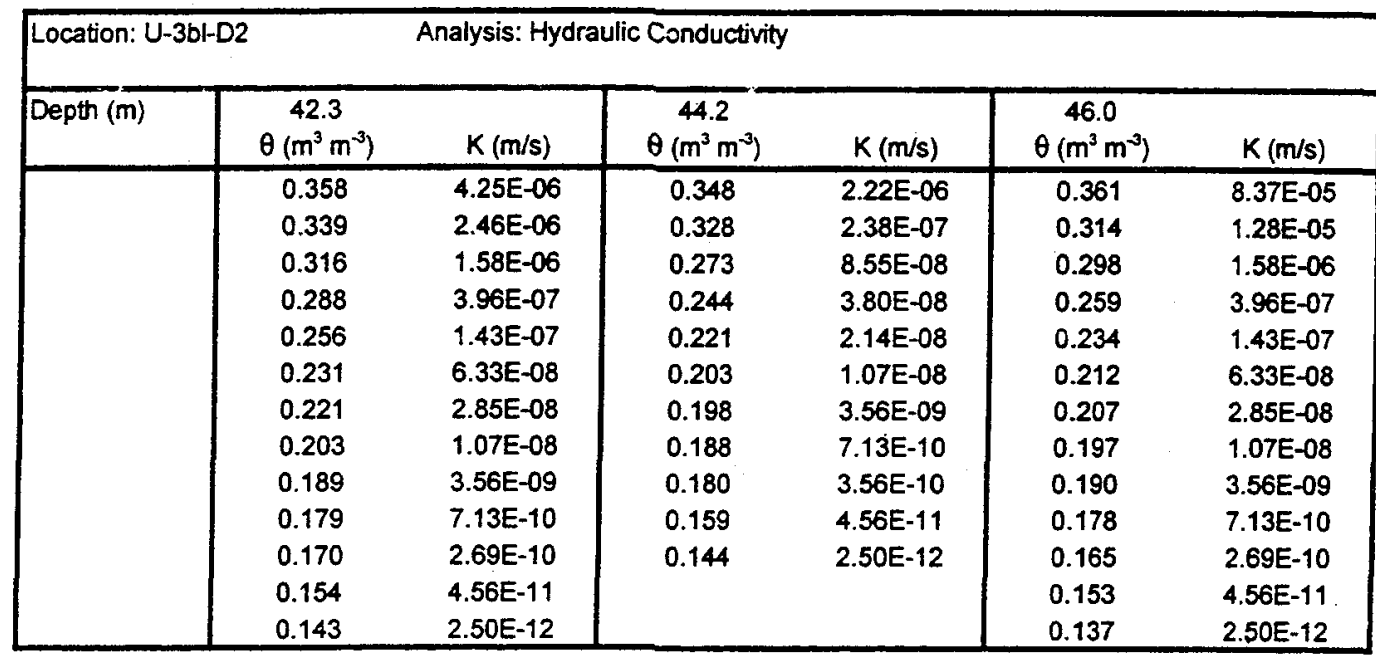

\begin{tabular}{|l|cc|cc|cc|}
\hline Location: U-3bI-D2 & \multicolumn{7}{c|}{ Analysis: Hydraulic Conductivity } \\
\hline Depth (m) & $\begin{array}{c}48.1 \\
\theta\left(\mathrm{m}^{3} \mathrm{~m}^{-3}\right)\end{array}$ & $\mathrm{K}(\mathrm{m} / \mathrm{s})$ & $\begin{array}{c}50.1 \\
\theta\left(\mathrm{m}^{3} \mathrm{~m}^{-3}\right)\end{array}$ & $\mathrm{K}(\mathrm{m} / \mathrm{s})$ & $\begin{array}{c}52.0 \\
\theta\left(\mathrm{m}^{3} \mathrm{~m}^{-3}\right)\end{array}$ & $\mathrm{K}(\mathrm{m} / \mathrm{s})$ \\
\hline & 0.434 & $3.29 \mathrm{E}-05$ & 0.458 & $2.53 \mathrm{E}-05$ & 0.377 & $8.86 \mathrm{E}-06$ \\
& 0.396 & $3.70 \mathrm{E}-06$ & 0.409 & $1.82 \mathrm{E}-06$ & 0.370 & $3.96 \mathrm{E}-07$ \\
& 0.391 & $1.58 \mathrm{E}-06$ & 0.375 & $3.96 \mathrm{E}-07$ & 0.329 & $1.43 \mathrm{E}-07$ \\
& 0.360 & $3.96 \mathrm{E}-07$ & 0.331 & $1.43 \mathrm{E}-07$ & 0.299 & $6.33 \mathrm{E}-08$ \\
& 0.321 & $1.43 \mathrm{E}-07$ & 0.292 & $6.33 \mathrm{E}-08$ & 0.286 & $2.85 \mathrm{E}-08$ \\
& 0.291 & $6.33 \mathrm{E}-08$ & 0.284 & $2.85 \mathrm{E}-08$ & 0.270 & $1.07 \mathrm{E}-08$ \\
& 0.260 & $2.85 \mathrm{E}-08$ & 0.273 & $1.07 \mathrm{E}-08$ & 0.256 & $3.56 \mathrm{E}-09$ \\
& 0.250 & $1.07 \mathrm{E}-08$ & 0.258 & $3.56 \mathrm{E}-09$ & 0.240 & $7.13 \mathrm{E}-10$ \\
& 0.248 & $3.56 \mathrm{E}-09$ & 0.241 & $7.13 \mathrm{E}-10$ & 0.225 & $2.69 \mathrm{E}-10$ \\
& 0.241 & $7.13 \mathrm{E}-10$ & 0.223 & $2.69 \mathrm{E}-10$ & 0.209 & $5.39 \mathrm{E}-11$. \\
& 0.229 & $2.69 \mathrm{E}-10$ & 0.207 & $4.56 \mathrm{E}-11$ & 0.189 & $2.50 \mathrm{E}-12$ \\
& 0.208 & $4.56 \mathrm{E}-11$ & 0.187 & $2.50 \mathrm{E}-12$ & & \\
& 0.192 & $2.50 \mathrm{E}-12$ & & & & \\
&
\end{tabular}

\begin{tabular}{|l|cc|cc|cc|}
\hline Location: U-3bi-D2 & \multicolumn{7}{c|}{ Analysis: Hydraulic Conductivity } \\
\hline Depth (m) & $\begin{array}{c}54.0 \\
\theta\left(\mathrm{m}^{3} \mathrm{~m}^{-3}\right)\end{array}$ & $\mathrm{K}(\mathrm{m} / \mathrm{s})$ & $\begin{array}{c}55.8 \\
\left(\mathrm{~m}^{3} \mathrm{~m}^{3}\right)\end{array}$ & $\mathrm{K}(\mathrm{m} / \mathrm{s})$ & $\theta\left(\mathrm{m}^{3} \mathrm{~m}^{-3}\right)$ & $\mathrm{K}(\mathrm{m} / \mathrm{s})$ \\
\hline & 0.458 & $1.27 \mathrm{E}-06$ & 0.476 & $9.68 \mathrm{E}-07$ & 0.492 & $1.46 \mathrm{E}-06$ \\
& 0.361 & $3.96 \mathrm{E}-07$ & 0.400 & $2.77 \mathrm{E}-07$ & 0.486 & $1.01 \mathrm{E}-06$ \\
& 0.305 & $1.43 \mathrm{E}-07$ & 0.367 & $9.98 \mathrm{E}-08$ & 0.436 & $3.96 \mathrm{E}-07$ \\
& 0.270 & $6.33 \mathrm{E}-08$ & 0.337 & $4.43 \mathrm{E}-08$ & 0.375 & $1.43 \mathrm{E}-07$ \\
& 0.242 & $2.85 \mathrm{E}-08$ & 0.307 & $1.07 \mathrm{E}-08$ & 0.312 & $6.33 \mathrm{E}-08$ \\
& 0.233 & $1.07 \mathrm{E}-08$ & 0.287 & $3.56 \mathrm{E}-09$ & 0.270 & $2.85 \mathrm{E}-08$ \\
& 0.225 & $3.56 \mathrm{E}-09$ & 0.270 & $7.13 \mathrm{E}-10$ & 0.256 & $1.07 \mathrm{E}-08$ \\
& 0.214 & $7.13 \mathrm{E}-10$ & 0.255 & $2.69 \mathrm{E}-10$ & 0.235 & $3.56 \mathrm{E}-09$ \\
& 0.205 & $2.69 \mathrm{E}-10$ & 0.241 & $4.56 \mathrm{E}-11$ & 0.203 & $7.13 \mathrm{E}-10$ \\
& 0.185 & $4.56 \mathrm{E}-11$ & 0.226 & $2.50 \mathrm{E}-12$ & 0.181 & $4.56 \mathrm{E}-11$ \\
& 0.169 & $2.5 \mathrm{EE}-12$ & & & 0.161 & $2.50 \mathrm{E}-12$ \\
& & & & & & \\
& & & & & & \\
\end{tabular}


Table D-5. Hydraulic conductivity - water content relations for U-3bl-D2 characterization samples (continued)

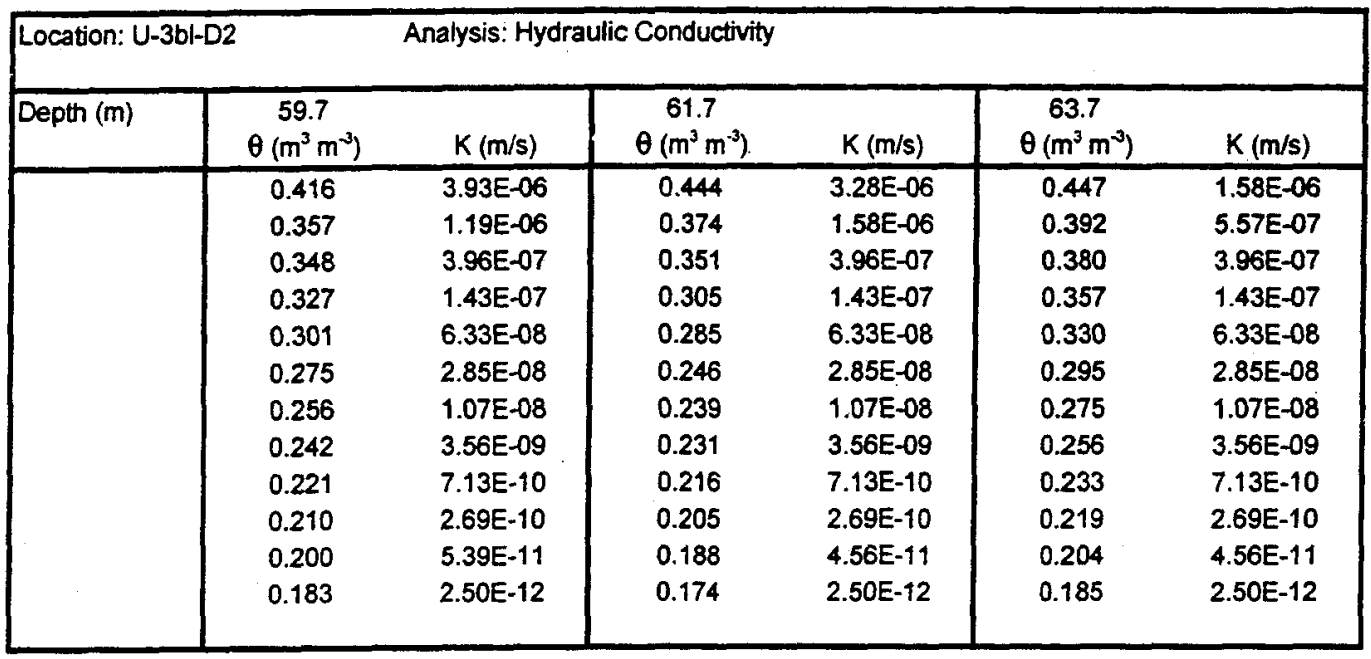

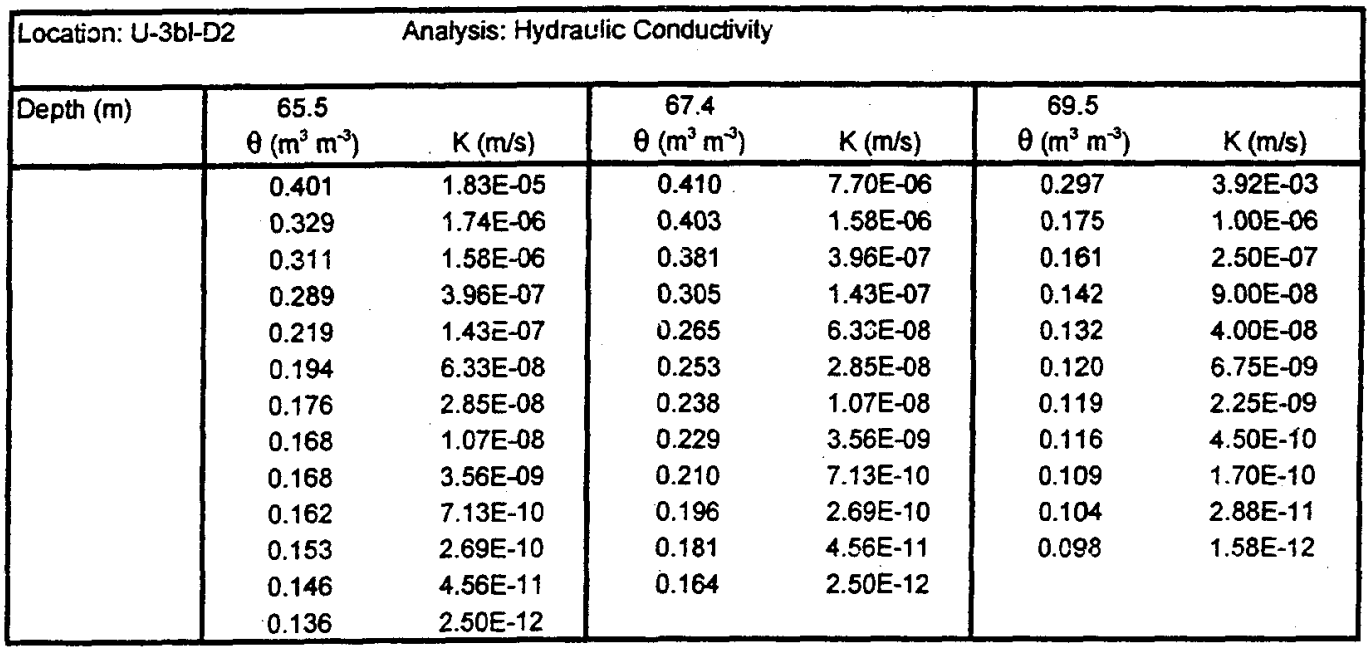

\begin{tabular}{|l|l|c|cc|cc|}
\hline Location: U-3bI-D2 & \multicolumn{1}{c|}{ Analysis: Hydraulic Conductivity } \\
\hline Depth $(\mathrm{m})$ & $\begin{array}{c}71.4 \\
\theta\left(\mathrm{m}^{3} \mathrm{~m}^{-3}\right)\end{array}$ & $\mathrm{K}(\mathrm{m} / \mathrm{s})$ & $\theta\left(\mathrm{m}^{3} \mathrm{~m}^{-3}\right)$ & $\mathrm{K}(\mathrm{m} / \mathrm{s})$ & $\theta\left(\mathrm{m}^{3} \mathrm{~m}^{-3}\right)$ & $\mathrm{K}(\mathrm{m} / \mathrm{s})$ \\
\hline & 0.445 & $2.67 \mathrm{E}-06$ & 0.324 & $5.34 \mathrm{E}-06$ & 0.391 & $6.90 \mathrm{E}-06$ \\
& 0.453 & $4.00 \mathrm{E}-06$ & 0.289 & $2.77 \mathrm{E}-06$ & 0.364 & $1.58 \mathrm{E}-06$ \\
& 0.417 & $1.58 \mathrm{E}-06$ & 0.275 & $1.58 \mathrm{E}-06$ & 0.361 & $3.96 \mathrm{E}-07$ \\
& 0.396 & $3.96 \mathrm{E}-07$ & 0.259 & $3.96 \mathrm{E}-07$ & 0.289 & $1.43 \mathrm{E}-07$ \\
& 0.361 & $1.43 \mathrm{E}-07$ & 0.216 & $1.43 \mathrm{E}-07$ & 0.264 & $6.33 \mathrm{E}-08$ \\
& 0.336 & $6.33 \mathrm{E}-08$ & 0.199 & $6.33 \mathrm{E}-08$ & 0.228 & $2.85 \mathrm{E}-08$ \\
& 0.295 & $3.56 \mathrm{E}-09$ & 0.178 & $1.07 \mathrm{E}-08$ & 0.220 & $1.07 \mathrm{E}-08$ \\
& 0.276 & $7.13 \mathrm{E}-10$ & 0.170 & $3.56 \mathrm{E}-09$ & 0.212 & $3.56 \mathrm{E}-09$ \\
& 0.261 & $2.69 \mathrm{E}-10$ & 0.159 & $7.13 \mathrm{E}-10$ & 0.203 & $7.13 \mathrm{E}-10$ \\
& 0.239 & $4.56 \mathrm{E}-11$ & 0.152 & $2.69 \mathrm{E}-10$ & 0.196 & $2.69 \mathrm{E}-10$ \\
& 0.221 & $2.50 \mathrm{E}-12$ & 0.141 & $4.56 \mathrm{E}-11$ & 0.182 & $4.56 \mathrm{E}-11$ \\
& & & 0.129 & $2.50 \mathrm{E}-12$ & 0.166 & $2.50 \mathrm{E}-12$ \\
& & & & & & \\
\hline
\end{tabular}


Table D-5. Hydraulic conductivity - water content relations for U-3bl-D2 characterization samples (continued)

\begin{tabular}{|l|cc|cc|cc|}
\hline Location: U-3bl-D2 & \multicolumn{7}{c|}{ Analysis: Hydraulic Conductivity } \\
\hline Depth (m) & $\begin{array}{c}77.2 \\
\theta\left(\mathrm{m}^{3} \mathrm{~m}^{-3}\right)\end{array}$ & $\mathrm{K}(\mathrm{m} / \mathrm{s})$ & $\theta\left(\mathrm{m}^{3} \mathrm{~m}^{-3}\right)$ & $\mathrm{K}(\mathrm{m} / \mathrm{s})$ & $\theta\left(\mathrm{m}^{3} \mathrm{~m}^{-3}\right)$ & $\mathrm{K}(\mathrm{m} / \mathrm{s})$ \\
\hline & 0.437 & $2.26 \mathrm{E}-06$ & 0.361 & $3.92 \mathrm{E}-05$ & 0.394 & $1.12 \mathrm{E}-05$ \\
& 0.405 & $1.38 \mathrm{E}-06$ & 0.349 & $1.28 \mathrm{E}-05$ & 0.374 & $1.58 \mathrm{E}-06$ \\
& 0.381 & $2.77 \mathrm{E}-07$ & 0.315 & $1.58 \mathrm{E}-06$ & 0.346 & $3.96 \mathrm{E}-07$ \\
& 0.358 & $9.98 \mathrm{E}-08$ & 0.294 & $3.96 \mathrm{E}-07$ & 0.243 & $1.43 \mathrm{E}-07$ \\
& 0.325 & $4.43 \mathrm{E}-08$ & 0.252 & $1.43 \mathrm{E}-07$ & 0.210 & $6.33 \mathrm{E}-08$ \\
& 0.288 & $1.07 \mathrm{E}-08$ & 0.227 & $6.33 \mathrm{E}-08$ & 0.193 & $2.85 \mathrm{E}-08$ \\
& 0.272 & $3.56 \mathrm{E}-09$ & 0.219 & $2.85 \mathrm{E}-08$ & 0.174 & $1.07 \mathrm{E}-08$ \\
& 0.252 & $7.13 \mathrm{E}-10$ & 0.217 & $1.07 \mathrm{E}-08$ & 0.170 & $3.56 \mathrm{E}-09$ \\
& 0.239 & $2.69 \mathrm{E}-10$ & 0.206 & $3.56 \mathrm{E}-09$ & 0.154 & $7.13 \mathrm{E}-10$ \\
& 0.224 & $4.56 \mathrm{E}-11$ & 0.200 & $7.13 \mathrm{E}-10$ & 0.142 & $2.69 \mathrm{E}-10$ \\
& 0.210 & $2.50 \mathrm{E}-12$ & 0.188 & $2.69 \mathrm{E}-10$ & 0.131 & $4.56 \mathrm{E}-11$ \\
& & & 0.177 & $4.56 \mathrm{E}-11$ & 0.114 & $2.50 \mathrm{E}-12$ \\
& & & 0.140 & $2.50 \mathrm{E}-12$ & & \\
\hline
\end{tabular}

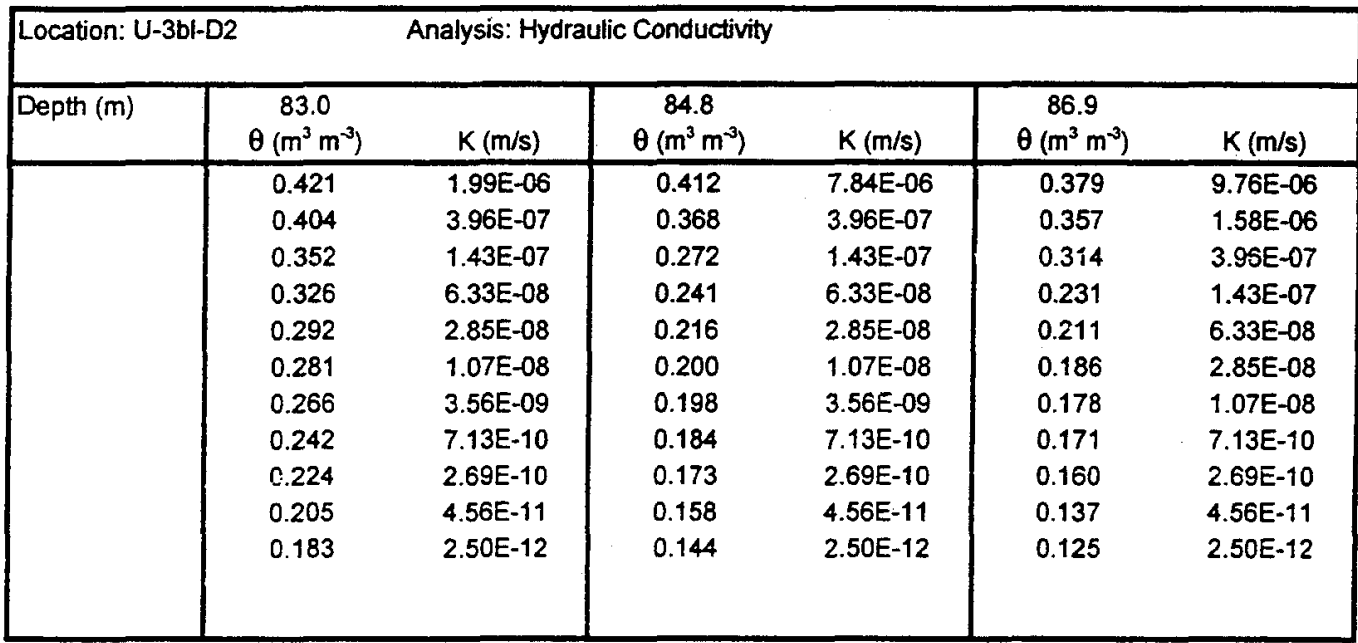

\begin{tabular}{|l|cc|cc|cc|}
\hline Location: U-3bI-D2 & \multicolumn{7}{c|}{ Analysis: Hydraulic Conductivity } \\
\hline Depth $(\mathrm{m})$ & $\begin{array}{c}88.9 \\
\theta\left(\mathrm{m}^{3} \mathrm{~m}^{-3}\right)\end{array}$ & $\mathrm{K}(\mathrm{m} / \mathrm{s})$ & $\theta\left(\mathrm{m}^{3} \mathrm{~m}^{-3}\right)$ & $\mathrm{K}(\mathrm{m} / \mathrm{s})$ & $\theta\left(\mathrm{m}^{3} \mathrm{~m}^{-3}\right)$ & $\mathrm{K}(\mathrm{m} / \mathrm{s})$ \\
\hline & 0.460 & $1.02 \mathrm{E}-06$ & 0.467 & $3.69 \mathrm{E}-06$ & 0.423 & $1.02 \mathrm{E}-05$ \\
& 0.404 & $3.96 \mathrm{E}-07$ & 0.452 & $1.58 \mathrm{E}-06$ & 0.386 & $3.96 \mathrm{E}-07$ \\
& 0.377 & $1.43 \mathrm{E}-07$ & 0.435 & $3.96 \mathrm{E}-07$ & 0.308 & $1.43 \mathrm{E}-07$ \\
& 0.347 & $6.33 \mathrm{E}-08$ & 0.395 & $1.43 \mathrm{E}-07$ & 0.280 & $6.33 \mathrm{E}-08$ \\
& 0.329 & $2.85 \mathrm{E}-08$ & 0.379 & $6.33 \mathrm{E}-08$ & 0.266 & $2.85 \mathrm{E}-08$ \\
& 0.315 & $1.07 \mathrm{E}-08$ & 0.350 & $2.85 \mathrm{E}-08$ & 0.247 & $1.07 \mathrm{E}-08$ \\
& 0.297 & $3.56 \mathrm{E}-09$ & 0.342 & $1.07 \mathrm{E}-08$ & 0.242 & $3.56 \mathrm{E}-09$ \\
& 0.276 & $7.13 \mathrm{E}-10$ & 0.314 & $3.56 \mathrm{E}-09$ & 0.224 & $7.13 \mathrm{E}-10$ \\
& 0.253 & $2.69 \mathrm{E}-10$ & 0.295 & $7.13 \mathrm{E}-10$ & 0.208 & $2.69 \mathrm{E}-10$ \\
& 0.230 & $4.56 \mathrm{E}-11$ & 0.264 & $2.69 \mathrm{E}-10$ & 0.188 & $4.56 \mathrm{E}-11$ \\
& 0.206 & $2.50 \mathrm{E}-12$ & 0.252 & $4.56 \mathrm{E}-11$ & 0.174 & $2.50 \mathrm{E}-12$ \\
& & & 0.240 & $2.50 \mathrm{E}-12$ & & \\
& & & & & & \\
& & & & &
\end{tabular}


Table D-5. Hydraulic conductivity - water content relations for U-3bl-D2 characterization samples (continued)

\begin{tabular}{|l|cc|cc|c|}
\hline Location: U-3bl-D2 & \multicolumn{5}{|c|}{ Analysis: Hydraulic Conductivity } \\
\hline Depth $(\mathrm{m})$ & $\begin{array}{c}94.6 \\
\theta\left(\mathrm{m}^{3} \mathrm{~m}^{-3}\right)\end{array}$ & $\mathrm{K}(\mathrm{m} / \mathrm{s})$ & $\theta\left(\mathrm{m}^{3} \mathrm{~m}^{-3}\right)$ & $\mathrm{K}(\mathrm{m} / \mathrm{s})$ & \\
\hline & 0.429 & $5.65 \mathrm{E}-06$ & 0.426 & $3.26 \mathrm{E}-06$ & \\
& 0.414 & $1.91 \mathrm{E}-06$ & 0.405 & $3.96 \mathrm{E}-07$ & \\
& 0.384 & $1.58 \mathrm{E}-06$ & 0.343 & $1.43 \mathrm{E}-07$ & \\
& 0.343 & $3.96 \mathrm{E}-07$ & 0.310 & $6.33 \mathrm{E}-08$ & \\
& 0.323 & $1.43 \mathrm{E}-07$ & 0.276 & $2.85 \mathrm{E}-08$ & \\
& 0.311 & $6.33 \mathrm{E}-08$ & 0.267 & $1.07 \mathrm{E}-08$ & \\
& 0.278 & $1.07 \mathrm{E}-08$ & 0.245 & $3.56 \mathrm{E}-09$ & \\
& 0.246 & $7.13 \mathrm{E}-10$ & 0.217 & $7.13 \mathrm{E}-10$ & \\
& 0.232 & $2.69 \mathrm{E}-10$ & 0.203 & $2.69 \mathrm{E}-10$ & \\
& 0.214 & $4.56 \mathrm{E}-19$ & 0.197 & $4.56 \mathrm{E}-11$ & \\
& 0.200 & $2.50 \mathrm{E}-12$ & 0.189 & $2.50 \mathrm{E}-12$ & \\
& & & & & \\
& & & & & \\
& & & & &
\end{tabular}


Table D-6. Volumetric water content for U-3bl-D2 characterization samples

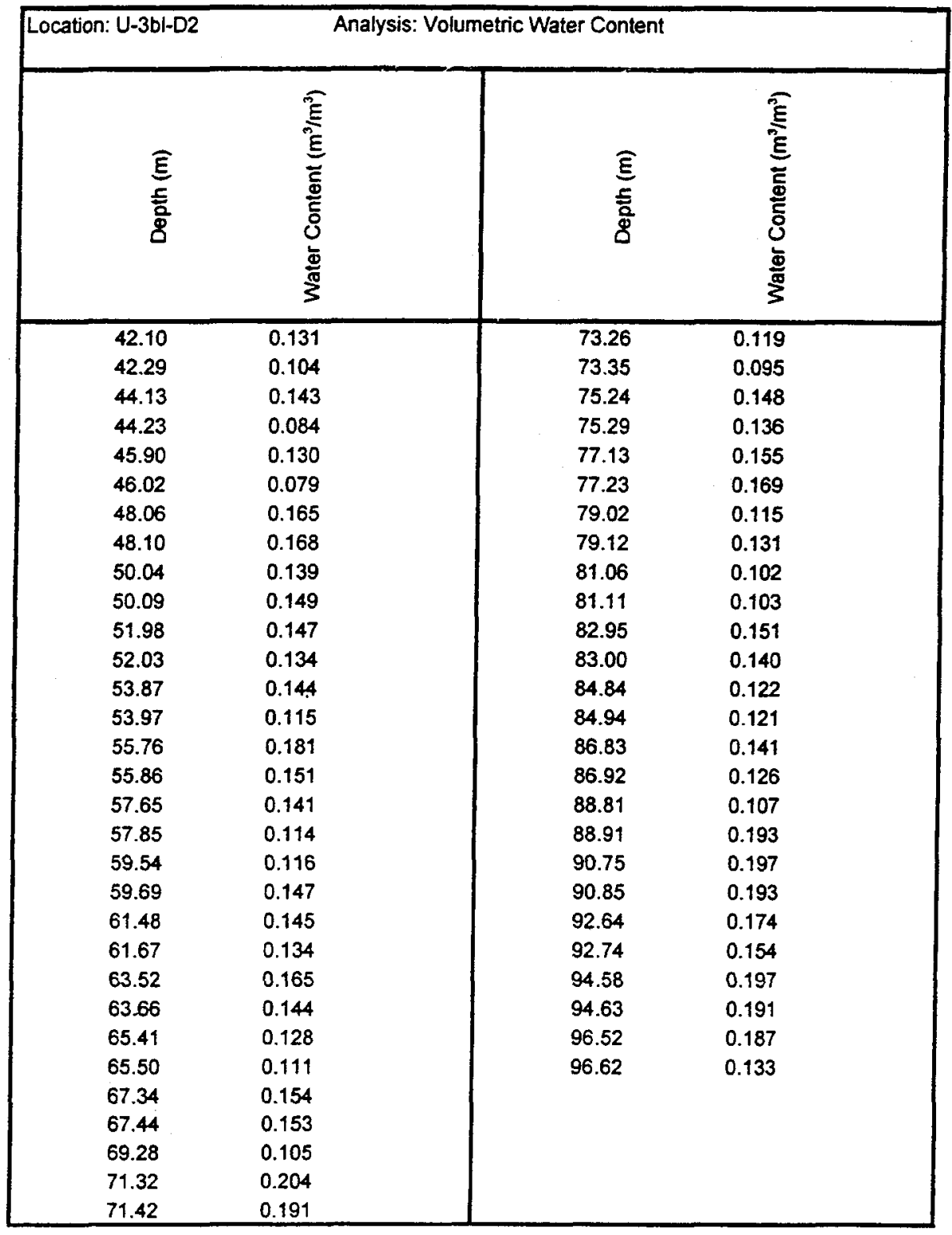


Table D-7. Water potential for U-3bI-D2 characterization samples

\begin{tabular}{|c|c|}
\hline Location: U-3bl-D2 & Analysis: Water Potential \\
\hline $\begin{array}{l}\widehat{E} \\
\bar{E} \\
\overline{\bar{g}}\end{array}$ & 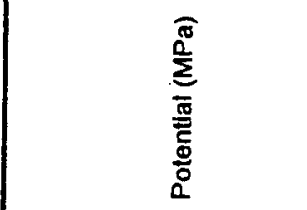 \\
\hline 42.10 & -1.873 \\
\hline 44.13 & -1.462 \\
\hline 45.90 & -1.832 \\
\hline 48.06 & -1.143 \\
\hline 50.04 & -0.914 \\
\hline 51.98 & -1.236 \\
\hline 53.87 & -1.652 \\
\hline 55.86 & -1.375 \\
\hline 57.65 & -1.099 \\
\hline 59.54 & -1.145 \\
\hline 61.48 & -0.871 \\
\hline 63.52 & -0.687 \\
\hline 65.41 & -1.379 \\
\hline 67.34 & -0.780 \\
\hline 69.28 & -1.236 \\
\hline 71.32 & -0.778 \\
\hline 73.26 & -1.238 \\
\hline 75.24 & -1.146 \\
\hline 77.13 & -0.871 \\
\hline 79.02 & -1.285 \\
\hline 81.11 & -1.378 \\
\hline 82.95 & -1.148 \\
\hline 84.94 & -0.826 \\
\hline 86.83 & -0.964 \\
\hline 88.81 & -0.918 \\
\hline 90.75 & -0.689 \\
\hline 92.64 & -0.552 \\
\hline 94.58 & -0.414 \\
\hline 96.62 & -0.875 \\
\hline
\end{tabular}


Table D-8. Stable isotope concentrations for U-3bI-D2 characterization samples

\begin{tabular}{|c|c|c|}
\hline Location: U-3bl-D2 & & le Isotopes \\
\hline $\begin{array}{l}\widehat{\underline{E}} \\
\frac{\bar{E}}{\bar{\sigma}} \\
\bar{g}\end{array}$ & $\frac{i}{2}$ & $\frac{\overline{8}}{20}$ \\
\hline 42.39 & -12.9 & -110 \\
\hline 44.08 & -14.7 & -112 \\
\hline 45.97 & -15.2 & -115 \\
\hline 47.96 & -14.9 & -114 \\
\hline 49.80 & -14.5 & -112 \\
\hline 52.08 & -14.4 & -115 \\
\hline 53.82 & -14.9 & -118 \\
\hline 55.96 & -14.7 & -117 \\
\hline 57.89 & -14.6 & -116 \\
\hline 59.49 & -14.6 & .117 \\
\hline 61.77 & -14.3 & -116 \\
\hline 63.37 & -15.0 & -117 \\
\hline 65.31 & -14.7 & -117 \\
\hline 67.54 & -14.8 & -117 \\
\hline 69.09 & -14.2 & -114 \\
\hline 71.22 & -14.8 & -117 \\
\hline 73.16 & -15.2 & -116 \\
\hline 75.10 & -15.0 & -118 \\
\hline 76.99 & -15.0 & -118 \\
\hline 78.93 & -15.0 & -117 \\
\hline 80.87 & -15.0 & -117 \\
\hline 83.05 & -14.5 & .113 \\
\hline 84.79 & -14.0 & -112 \\
\hline 86.63 & -14.8 & -117 \\
\hline 88.62 & .14 .6 & -112 \\
\hline 90.56 & -13.9 & -112 \\
\hline 92.45 & -14.6 & -115 \\
\hline 94.44 & -14.5 & -110 \\
\hline 96.37 & -14.3 & -110 \\
\hline
\end{tabular}


Table D-9. Soil chloride concentrations for U-3bl-D2 characterization samples

\begin{tabular}{|c|c|}
\hline Location: U-3b1-D2 & Analysis: Soil Chloride \\
\hline $\begin{array}{l}\widehat{\bar{E}} \\
\overline{\bar{z}} \\
\bar{g}\end{array}$ & 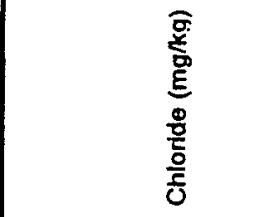 \\
\hline 42.17 & 0.8 \\
\hline 44.30 & 0.6 \\
\hline 45.88 & 0.7 \\
\hline 47.96 & 0.8 \\
\hline 49.92 & 0.7 \\
\hline 51.79 & 0.7 \\
\hline 53.75 & 0.7 \\
\hline 55.69 & 0.9 \\
\hline 57.68 & 0.5 \\
\hline 59.76 & 0.7 \\
\hline 61.60 & 0.7 \\
\hline 63.52 & 0.9 \\
\hline 65.41 & 0.7 \\
\hline 67.32 & 0.4 \\
\hline 69.21 & 0.5 \\
\hline 71.37 & 0.6 \\
\hline 73.31 & 0.4 \\
\hline 75.15 & 0.4 \\
\hline 77.06 & 0.3 \\
\hline 78.93 & 0.4 \\
\hline 80.94 & 0.3 \\
\hline 82.83 & 0.3 \\
\hline 84.67 & 52.4 \\
\hline 86.75 & 0.4 \\
\hline 88.74 & 0.4 \\
\hline 90.68 & 1.1 \\
\hline 92.57 & 0.4 \\
\hline 94.63 & 0.9 \\
\hline 96.54 & 0.4 \\
\hline
\end{tabular}


Table D-10. Soil carbonate concentrations for U-3bh-D2 characterization samples

\begin{tabular}{|c|c|}
\hline Location: U-3bl-D2 & Analysis: Soil Carbonate \\
\hline $\begin{array}{l}\widehat{\bar{\xi}} \\
\frac{\bar{g}}{\bar{g}} \\
\underline{g}\end{array}$ & 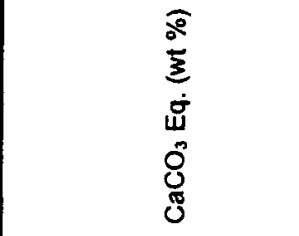 \\
\hline 42.17 & 11.09 \\
\hline 44.30 & 5.16 \\
\hline 45.88 & 15.57 \\
\hline 47.96 & 0.07 \\
\hline 49.92 & 0.00 \\
\hline 51.79 & 0.00 \\
\hline 53.75 & 1.20 \\
\hline 55.69 & 0.48 \\
\hline 57.68 & 2.60 \\
\hline 59.76 & 8.94 \\
\hline 61.60 & 1.92 \\
\hline 63.52 & 12.81 \\
\hline 65.41 & 0.48 \\
\hline 67.32 & 0.80 \\
\hline 69.21 & 0.61 \\
\hline 71.37 & 3.23 \\
\hline 73.31 & 0.30 \\
\hline 75.15 & 4.76 \\
\hline 77.06 & 8.75 \\
\hline 78.93 & 3.09 \\
\hline 80.94 & 2.08 \\
\hline 82.83 & 3.25 \\
\hline 84.67 & 8.46 \\
\hline 86.75 & 4.33 \\
\hline 88.74 & 1.78 \\
\hline 90.68 & 4.65 \\
\hline 92.57 & 3.91 \\
\hline 94.63 & 5.60 \\
\hline 96.54 & 1.59 \\
\hline
\end{tabular}


Table D-11. Tritium concentrations for U-3bl-D2 characterization samples

\begin{tabular}{|c|c|c|}
\hline Location: U-3bl-D2 & & Analysis: Tritium \\
\hline $\begin{array}{l}\widehat{\underline{E}} \\
\frac{\hat{\partial}}{\Phi} \\
\Phi\end{array}$ & 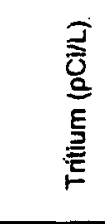 & 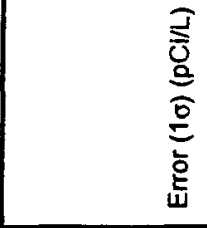 \\
\hline 42.34 & 5880 & 476 \\
\hline 44.03 & 5000 & 404 \\
\hline 45.83 & 4490 & 497 \\
\hline 48.15 & 3190 & 230 \\
\hline 49.85 & 3300 & 280 \\
\hline 51.88 & 2680 & 280 \\
\hline 54.02 & 3220 & 310 \\
\hline 55.81 & 2890 & 290 \\
\hline 57.70 & 3180 & 340 \\
\hline 59.64 & 3190 & 200 \\
\hline 61.53 & 3770 & 320 \\
\hline 63.42 & 5740 & 220 \\
\hline 65.60 & 4980 & 280 \\
\hline 67.20 & 4430 & 290 \\
\hline 69.14 & 5980 & 260 \\
\hline 71.17 & 6130 & 460 \\
\hline 73.06 & 7740 & 320 \\
\hline 75.05 & 12150 & 320 \\
\hline 76.94 & 7410 & 430 \\
\hline 79.22 & 9340 & 320 \\
\hline 81.16 & 6240 & 450 \\
\hline 82.90 & 6220 & 430 \\
\hline 84.74 & 6650 & 360 \\
\hline 86.68 & 4350 & 230 \\
\hline 88.67 & 4620 & 320 \\
\hline 90.61 & 5140 & 410 \\
\hline 92.50 & 6340 & 360 \\
\hline 94.48 & 7410 & 330 \\
\hline 96.47 & 5840 & 390 \\
\hline
\end{tabular}




\section{$\underline{\text { Copies }}$}

Jhon Carilli

4 (uncontrolled)

Waste Management Project

U.S. Department of Energy

National Nuclear Security Administration

Nevada Site Office

P.O. Box 98518, M/S 505

Las Vegas, NV 89193-8518

Angela P. Colaruso

1 (uncontrolled)

Waste Management Project

U.S. Department of Energy

National Nuclear Security Administration

Nevada Site Office

P.O. Box 98518, M/S 505

Las Vegas, NV 89193-8518

B.M. Crowe

1 (uncontrolled)

Apogen Technologies

U.S. Department of Energy

National Nuclear Security Administration

Nevada Site Office

P.O. Box 98518, M/S 505

Las Vegas, NV 89193-8518

Sabine Curtis

Environmental Restoration Project

U.S. Department of Energy

National Nuclear Security Administration

Nevada Site Office

P.O. Box 98518, M/S 505

Las Vegas, NV 89193-8518

U.S. Department of Energy

1 (uncontrolled)

National Nuclear Security Administration

Nevada Site Office

Technical Library

P.O. Box 98518, M/S 505

Las Vegas, NV 89193-8518

1 (uncontrolled)

Distribution-1 


\section{Distribution List (continued)}

\section{Copies}

U.S. Department of Energy

2 (uncontrolled)

National Nuclear Security Administration

Nevada Site Office

Public Reading Facility

c/o Nuclear Testing Archive

P.O. Box 98521, M/S 400

Las Vegas, NV 89193-8521

U.S. Department of Energy

1 (electronic, uncontrolled)

Office of Scientific and Technical Information

Post Office Box 62

Oak Ridge, TN 37831-0062

Lloyd Desotell

1 (uncontrolled)

National Security Technologies, LLC

P.O. Box 98521, M/S NSF081

Las Vegas, NV 89193-8521

Max Dolenc

1 (uncontrolled)

National Security Technologies, LLC

P.O. Box 98521, M/S NSF083

Las Vegas, NV 89193-8521

Steve Nacht

1 (uncontrolled)

National Security Technologies, LLC

P.O. Box 98521, M/S NSF083

Las Vegas, NV 89193-8521

Terry Ploeger

1 (uncontrolled)

National Security Technologies, LLC

P.O. Box 98521, M/S NTS404

Las Vegas, NV 89193-8521

Stuart Rawlinson

1 (uncontrolled)

National Security Technologies, LLC

P.O. Box 98521, M/S NTS416

Las Vegas, NV 89193-8521

Greg Shott

1 (uncontrolled)

National Security Technologies, LLC

P.O. Box 98521, M/S NSF081

Las Vegas, NV 89193-8521 


\section{Distribution List (continued)}

\section{$\underline{\text { Copies }}$}

Dan Tobiason

1 (uncontrolled)

National Security Technologies, LLC

P.O. Box 98521, M/S NTS416

Las Vegas, NV 89193-8521

Kathy Umbarger

1 (uncontrolled)

National Security Technologies, LLC

P.O. Box 98521, M/S NLV081

Las Vegas, NV 89193-8521

Denise Wieland

1 (uncontrolled)

National Security Technologies, LLC

P.O. Box 98521, M/S NTS416

Las Vegas, NV 89193-8521 
This page intentionally left blank

Distribution-4 